UNIVERSIDADE DE SÃO PAULO

INSTITUTO DE PSICOLOGIA

ANABELA ALMEIDA COSTA E SANTOS

CADERNOS E OUTROS REGISTROS ESCOLARES

DA PRIMEIRA ETAPA DO ENSINO FUNDAMENTAL:

UM OLHAR DA PSICOLOGIA ESCOLAR CRÍTICA

São Paulo 
AUTORIZO A REPRODUÇÃO E DIVULGAÇÃO TOTAL OU PARCIAL DESTE TRABALHO, POR QUALQUER MEIO CONVENCIONAL OU ELETRÔNICO, PARA FINS DE ESTUDO E PESQUISA, DESDE QUE CITADA A FONTE.

Catalogação na publicação

Serviço de Biblioteca e Documentação

Instituto de Psicologia da Universidade de São Paulo

Santos, Anabela Almeida Costa e.

Cadernos e outros registros escolares da primeira etapa do ensino fundamental: um olhar da psicologia escolar crítica / Anabela Almeida Costa e Santos; orientadora Marilene Proença Rebello de Souza. -- São Paulo, 2008.

$313 \mathrm{p}$.

Tese (Doutorado - Programa de Pós-Graduação em Psicologia. Área de Concentração: Psicologia Escolar e do Desenvolvimento Humano) - Instituto de Psicologia da Universidade de São Paulo.

1. Psicologia escolar 2. Cadernos escolares 3. Ensino fundamental 4. Etnografia I. Título. 


\title{
CADERNOS E OUTROS REGISTROS ESCOLARES DA PRIMEIRA ETAPA DO ENSINO FUNDAMENTAL: UM OLHAR DA PSICOLOGIA ESCOLAR CRÍTICA
}

\author{
Tese apresentada ao Instituto de Psicologia da \\ Universidade de São Paulo como exigência parcial para \\ obtenção do título de Doutora em Psicologia \\ Área de concentração: Psicologia Escolar e do \\ Desenvolvimento Humano \\ Orientadora: Prof ${ }^{a}$. Dr ${ }^{\mathrm{a}}$. Marilene Proença Rebello de \\ Souza
}

São Paulo 


\section{FOLHA DE APROVAÇÃO}

Anabela Almeida Costa e Santos

Cadernos e outros registros escolares da

primeira etapa do ensino fundamental:

um olhar da Psicologia Escolar Crítica

Tese apresentada ao Instituto de Psicologia da Universidade de São Paulo como exigência parcial para obtenção do título de Doutora em Psicologia Área de concentração: Psicologia Escolar e do Desenvolvimento Humano

Aprovada em:

\section{Banca Examinadora}

Nome:

Instituição:

Assinatura

Nome:

Instituição:

Assinatura

Nome:

Instituição:

Assinatura

Nome:

Instituição:

Assinatura

Nome:

Instituição:

Assinatura 


\section{AGRADECIMENTOS}

A Marilene Proença, querida orientadora, pela generosidade com que me guiou nesse trabalho e pelos muitos aprendizados que me proporcionou. Nesses anos de graduação, mestrado e doutorado, nossa convivência me possibilitou um crescimento que não se restringiu apenas aos saberes acadêmicos.

Às professoras brasileiras e francesas que me receberam em suas classes, permitindo que eu aprendesse com o fazer diário da sala de aula.

Aos alunos que disponibilizaram atenção e materiais. A energia, a alegria, o sofrimento e a capacidade de criação deles me moveram na escrita dessa tese.

À Fapesp pelo apoio financeiro fundamental para a realização de um trabalho como este. Tanto a dedicação necessária para uma pesquisa etnográfica quanto o estudo internacional não teriam sido possíveis sem esse respaldo.

AAdriana Marcondes Machado, que desde a minha graduação tem sido uma referência inspiradora. No Exame Geral de Qualificação, suas observações e sugestões foram fundamentais.

A Belmira Bueno, que, além de ter apresentado preciosas sugestões por ocasião do Exame Geral de Qualificação, foi extremamente prestativa nas intermediações necessárias para que o estágio no exterior pudesse ocorrer.

A Anne-Marie Chartier, que de modo tão acolhedor me recebeu na França. Além das valiosas contribuições para a estrutura da tese, me ajudou a compreender e conhecer a educação francesa. 
Ao INRP e seus funcionários, que sempre foram bastante prestativos. Especialmente a Nanou Duquenne que, com sua simpática companhia, tornou meus dias de trabalho mais agradáveis.

A Maria Silvia Pinto de Moura Librandi da Rocha, com quem, numa conversa informal, surgiu a idéia de pesquisar os cadernos. Interlocutora sempre presente, ainda que por vezes apenas em meus pensamentos.

A todos os membros do grupo de orientandos - Ana Karina Amorim Checchia, Flávia da Silva Ferreira Asbahr, Giuliana Temple, Jane Terezinha Domingues Cotrin, Lygia de Sousa Viégas, Marcelo Domingues Roman, Roseli Lins Caldas e Záira Fátima de Rezende Gonzalez Leal -, que nas conversas formais e informais questionaram, sugeriram, acrescentaram. Nossos encontros contribuíram muito para minha formação como pesquisadora e psicóloga escolar.

A Beatriz de Paula Souza, que, com seus convites - para escrever um capítulo de livro, para participar de um curso ou para uma boa conversa -, foi me mostrando caminhos importantes.

A Natali Tiburcio, que, com seu jeito doce e eficiente, filmou as entrevistas e as transcreveu.E, acima de tudo, foi uma ótima companheira de campo.

A Paula Saretta, companheira mais recente de reflexões, cujo olhar aguçado para o contexto e as produções escolares me desafiou a pensar e escrever.

Às sempre amigas Audrey Weyler e Walkíria Duarte, companheiras de todas as horas. Saber que podia contar incondicionalmente com vocês sempre foi um alento. 
Aos meus sogros, Maria Miriam e Silva Peretta e Vitor José Peretta, que apoiaram tão compreensivamente minhas ausências durante a dedicação final à tese.

À minha mãe e à minha avó, Maria José Almeida Costa e Santos e Mavilde Ferreira Dias dos Santos, pelo apoio, compreensão, incentivo e carinho.

Ao meu marido Igor Santos Peretta, presença atenciosa, acolhedora, paciente e fundamental. Com quem dividi idéias, sonhos e angústias. Ouvinte e leitor fiel. E, como se não bastasse tudo isso, ainda consertou o computador, diagramou a tese... Apoio sem fim. 


\section{RESUMO}

Santos, Anabela Almeida Costa e. Cadernos e outros registros escolares da primeira etapa do ensino fundamental: um olhar da psicologia escolar crítica. 2008. $313 \mathrm{f}$. Tese (Doutorado) - Instituto de Psicologia, Universidade de São Paulo, São Paulo, 2008.

Esta tese tem como objeto os cadernos escolares e demais registros elaborados prioritariamente pelos alunos no contexto escolar. Apesar de os registros serem componentes fundamentais das rotinas escolares, são elementos pouco estudados. Os trabalhos em psicologia que se dedicaram ao tema privilegiaram compreender essas produções escolares com base na psicometria e/ou como expressões da personalidade e de estados afetivo-emocionais dos alunos. Tal forma de compreender os registros produzidos na escola se revela inadequada, pois considera-os apenas produções discentes, ignorando o contexto institucional e relacional em meio ao qual são realizadas as atividades escolares. Diante da necessidade de construir referenciais para a compreensão psicológica dos registros escolares que abrangessem os processos escolares que constituem os bastidores da realização dos registros, foi conduzida a pesquisa apresentada nesta tese. A investigação, conduzida com base em parâmetros teórico-metodológicos da psicologia escolar crítica e da etnografia educacional, compôs-se de três etapas. A primeira foi realizada em uma sala de aula de primeira série do ensino fundamental de escola pública do interior paulista; a segunda, efetuada na mesma escola, numa quarta série do ensino fundamental; e a terceira abrangeu um conjunto de salas de aula de escolas públicas francesas (de séries equivalentes à primeira etapa do ensino fundamental brasileiro). As duas primeiras etapas duraram, cada uma, um ano letivo completo e consistiram na realização de observações participantes nas salas de aula, entrevistas com alunos e professores. A etapa francesa, que durou cerca de dois meses e meio, foi composta por observações participantes em oito salas de aula e entrevistas com professores. Especial atenção foi dada à análise das informações relativas à quarta série, análise feita com a finalidade de responder às seguintes perguntas: onde se registra?; quem registra?; o que é registrado?; como se registra?; por que e para que são feitos os registros?. O contexto encontrado na quarta série foi comparado ao da primeira série, objetivando caracterizar processos e aprendizados, mediados pela realização de registros, necessários aos alunos para a inserção na cultura escolar. As informações oriundas da etapa francesa possibilitaram identificar como se diferenciam cadernos produzidos em outros contextos culturais. A pesquisa documenta os bastidores da realização de produções escolares dos alunos, descrevendo aspectos que escapam à possibilidade de registro, mas que são fundamentais para a compreensão desses materiais. Os resultados encontrados revelam a necessidade de que o psicólogo disposto a utilizar, como ferramenta de trabalho, os cadernos e demais registros escolares deve investigar, ao máximo, em que condições institucionais, relacionais e situacionais foram produzidos tais documentos.

Palavras-chave: Cadernos escolares. Ensino fundamental. Psicologia escolar. Etnografia. 


\section{ABSTRACT}

Santos, Anabela Almeida Costa e. Notebooks and other school records in the first stage of Elementary school: a perspective from Critical School Psychology. 2008. 313 p. Thesis (Doctoral) - Instituto de Psicologia, Universidade de São Paulo, São Paulo, 2008.

This research investigates notebooks and further records composed mainly by students within a school context. Over the fact school records are fundamental elements in school routines, there are still few studies on them. Works in Psychology, that had been devoted to this theme, benefit the understanding of these school productions as based on Psychometrics, also, as pure student's personality and affective-emotional states expressions. This way of comprehending these school produced records reveals itself inappropriate, once it considers them just as students personal productions, ignoring the institutional and relational context within school activities are done. This research was conducted by the necessity of constructing referentials to psychologically comprehend the school recordings that embrace the school proccesses which constitute the backgrounds of these records realization. The research, conducted by Critical School Psychology and Educational Ethnography theoretical-methodological parameters, is composed by three stages. The first stage was conducted in a First Grade classroom of a Brazilian Elementary public school, situated in a city in São Paulo State (southeastern Brazil); the second stage, conducted in the same school, took place in a Fourth Grade classroom; and the third stage embraces a set of French public school classrooms (equivalent to the first stage of Elementary Brazilian school). The first and the second stages lasted, each one, for one school year and were consisted of participative classroom observations and interviews with students and teachers. The French stage, that lasted about two and a half months, was consisted of participative observations in eight classrooms and interviews with teachers. Special attention was given to analysis of Fourth Grade related informations which had the objective of answering the following questions: Where is it recorded? Who is the recorder? What is recorded? How is it recorded? Why and for what is it recorded? The Fourth Grade context found was compared to the First Grade's, aiming to characterize processes and learnings, mediated by records compositions necessary to students for school culture insertion. The information gathered from French stage made it possible to identify how notebooks produced in other cultural contexts are different. This research reveals the background of students' school productions, describing aspects that escape from recording possibility, but are fundamental to the understanding of those materials. The results found reveals that the psychologist willing to use notebooks and other school records as working tools must investigate, carefully, in which institutional, relational and situational conditions those documents were produced.

Keywords: School Notebooks. Elementary School. School Psychology. Ethnography. 


\section{RÉSUMÉ}

Santos, Anabela Almeida Costa e. Cahiers et d'autres registres scolaires de la première étape d'enseignement fondamental : un regard de la psychologie scolaire critique. 2008. 313 p. Thèse (Doctorat) - Instituto de Psicologia, Universidade de São Paulo, São Paulo, 2008.

Cette thèse a pour objectif d'investiguer les cahiers scolaires et d'autres registres élaborés en priorité par des élèves dans le contexte scolaire. Considérant que ces registres sont des composants fondamentaux des routines scolaires, ils sont encore peu étudiés. Les recherches en psychologie dédiées à ce tème l'ont privilégié afin de mieux comprendre ces productions scolaires comme base en psycometrie et/ou comme expressions de la personnalité et d'états affectif-émotionnels des élèves. Cette façon de comprendre les registres produits dans l'école s'est révélée inadéquate, puisqu'elle les considère seulement comme des productions des élèves, déconsidérant le contexto institutionnel et relationnel où sont réalisées les activités scolaires. Au fait, cette recherche a été conduite devant la nécessité de construire des référentiels pour la compréhension psychologique des registres scolaires qui embrassaient les processus scolaires qui constituent les coulisses de la réalisation des registres. L'investigation, conduite sur la base de paramètres théoriqueméthodologiques de la psychologie scolaire et de l'éthnographie éducationnelle, a été composée de trois étapes. La première a été réalisée dans une salle de classe de " primeira série » de l'enseignement fondamental d'une école publique de l'intérieur de l'État de São Paulo (première année d'enseignement obligatoire au Brésil qui reçoit, en général, des enfant de 7 ans); la deuxième, qui a été conduite dans la même école, dans une « quarta série » de l'enseignement fondamental (quatrième année de l'enseignement obligatoire au Brésil qui reçoit des enfants à partir de l'âge de 10 ans) ; et la troisième, qui a embrassée un ensemble de salles de classe d'École Élémentaire des institutions publiques françaises. Les deux premières étapes ont duré, chaqu'une, une année scolaire complète et ont consistée à la réalisation des observations participantes dans les salles de classe, entretiens avec les élèves et professeurs. L'étape française, qui a durée environ deux mois et demi, a été composée d'observations participantes dans huit salles de classe et d'entretiens avec professeurs. Une attention espéciale a été faite à l'analyse des informations rélatives à la " quarta série », conduite visant à répondre à des questions suivantes : où se registre ?; qui registre ?; qu'est-ce qui est registré ?; comment est registré ?; pourquoi et pour quoi sont faits les registres ?. Le contexte trouvé sur la « quarta série " a été comparé à celui de la " primeira série " visant à caractériser des processus et apprentissages à travers la médiation de la réalisation de registres, nécessaires aux élèves pour l'insertion dans la culture scolaire. Les informations originaires de l'étape française ont possibilité d'identifier comment se différencient les cahiers produits dans d' autres contextes culturels. Cette recherche est un documente sur les coulisses de la réalisation de productions scolaires des élèves décrivant les aspects qui échapent à la possibilité d'être registrés, mais qui sont fondamentaux pour la compréhension de ces matériels. Les résultats trouvés révèlent qu'il appartient donc au psychologue, engagé à utiliser comme outil de travail les cahiers et d'autres registres scolaires, d'investiguer au maximum dans quelles conditions institutionnelles, relationnelles et situationnelles ont été produits ces documents.

Mots-clés : Cahiers scolaires. Enseignement fondamental. Psychologie scolaire. Ethnographie. 


\section{LISTA DE FIGURAS}

Figura 1. Produções de alunos: (a) Severino, (b) Mateus e (c) Ralph ............... 19

Figura 2. Quadro Comparativo dos Sistemas de Ensino Brasil-França...............82

Figura 3. Folhinha do Projeto Adolescer, colada em caderno de aluno ............994

Figura 4. Folhinha com enunciado de atividade ................................95

Figura 5. Caderno de Ralph, corrigido por Malu.............................. 102

Figura 6. Caderno de textos da aluna Jenifer, corrigido por Silvia .............. 103

Figura 7. Caderno de Alex com folhinha colada ............................... 104

Figura 8. Exercícios escritos pela professora no caderno de Jordan ............ 105

Figura 9. Bilhete escrito por professora e respondido por mãe de aluno ......... 108

Figura 10. Texto a reescrever copiado no caderno de Fabiana................ .111

Figura 11. Texto reescrito copiado no caderno de Fabiana $\ldots . \ldots \ldots \ldots \ldots \ldots \ldots \ldots \ldots . . .112$

Figura 12. Problema de matemática copiado no caderno de Fabiana ..............114

Figura 13. Atividade de matemática encontrada no caderno de Fabiana ............115

Figura 14. Desenho sobre o ciclo da água encontrado no caderno de Fabiana ......117

Figura 15. A homenagem de Cleber ao seu time de futebol ..................... 123

Figura 16. Produção de texto de Sandro com o tema “O planeta pede socorro” .. 135

Figura 17. Bilhete da professora para Sandro ............................... 135

Figura 18. Produção de texto de Jennifer com o tema “O planeta pede socorro" 136

Figura 19. Produção de texto de Jennifer com o tema “Páscoa” ................. 137

Figura 20. Redação de Alex, com o tema “A fofoqueira e o fofoqueiro” .......... 139

Figura 21. Produção de texto de Leonardo com o tema "Passeio delicioso" ...... 141

Figura 22. Produção de texto encontrada no caderno de Leonardo com o tema “A fofoqueira e o fofoqueiro" ..................................... 141

Figura 23. Produção de texto de Leonardo com o tema “O que é discriminação?” 142

Figura 24. Roteiro do dia encontrado no caderno de Cleber..................... 150

Figura 25. Castigo no caderno de Ralph .................................... 152 
Figura 26. Números por extenso no caderno de Cleber

Figura 27. Poema e perguntas no caderno de Cleber .......................... 163

Figura 28. Provas elaboradas, resolvidas e corrigidas por Fabiana ................ 183

Figura 29. Prova elaborada, resolvida e corrigida por Ralph.................... 184

Figura 30. Cópia sobre a multiplicação do número 7 , realizada em dezembro por

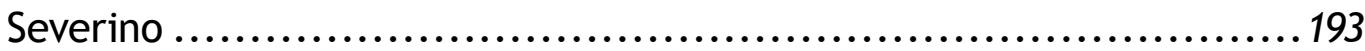

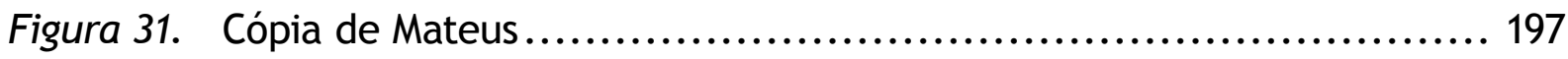

Figura 32. Produção de texto de Jordan com transcrição feita pela professora ... 205

Figura 33. Cópia e desenho no caderno de Ralph .............................. 209

Figura 34. Capa de caderno fornecido pela Mairie de Paris ...................... 216

Figura 35. Padrão de linhas de um caderno francês ................................219

Figura 36. Cópia de Moral realizada no ano de 1893 ............................ 220

Figura 37. Ditado registrado em 2002 no caderno de aluna de CM2, corrigido pela

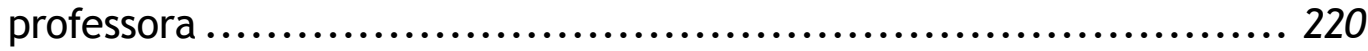

Figura 38. Caderno de Sophie com traçado de letras e sílabas.................... 223

Figura 39. Caderno de Sophie com cópia de números ......................... 225

Figura 40. Caderno de Louise, aluna de CM1, com correções da professora........ 226

Figura 41. Atividadeindividualizadasolicitadapelaprofessoraencontradanocaderno de Lucille...................................................... 227

Figura 42. Somas e comunicação docente no caderno de Hadi..................... 228

Figura 43. Tarefa não realizada no caderno de Hadi, justificativa da professora e comunicação relativa à disciplina .................................. 229

Figura 44. Comunicação feita pela professora no caderno de Lucille............... 231

Figura 45. Recomendação para que a aluna sublinhe o título, escrita pela professora no caderno de Lucille................................................ 235

Figura 46. Advertência relativa ao local onde deve ser escrito o título, encontrada no caderno de Lucille ............................................... 235

Figura 47. Lista de cadernos utilizados em sala de CP......................... 242 


\section{LISTA DE TABELAS}

Tabela 1. Número de observações em salas de aula de escolas francesas ...........82

Tabela 2. Comparação de registros entre a lousa e o caderno de Heitor..............151

Tabela 3. Lista de cadernos de uma sala de aula francesa .......................... 239 


\section{SUMÁRIO}

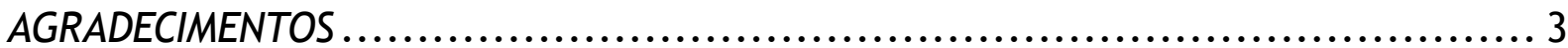

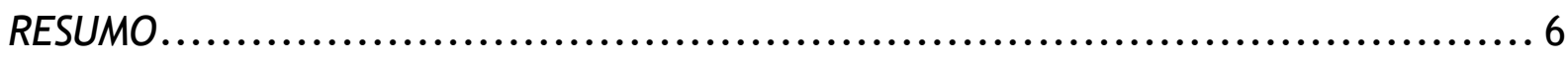

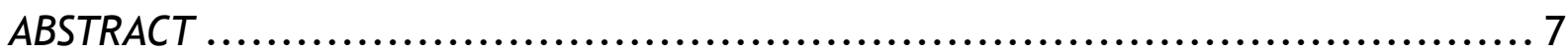

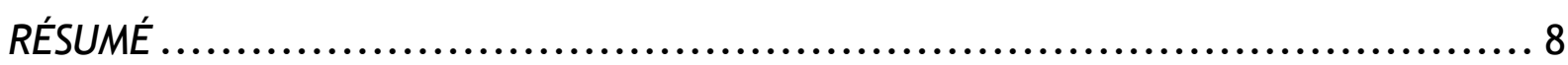

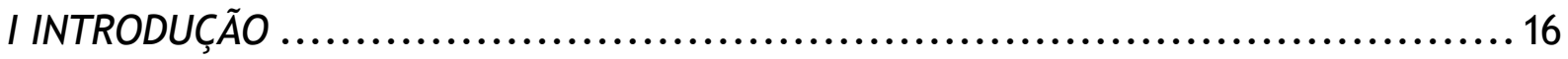

I.1 Como podem ser compreendidos os registros produzidos na escola?............ 16

I.2 Os olhares que a psicologia propôs para a compreensão dos cadernos escolares .20

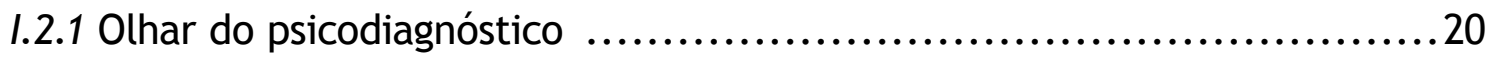

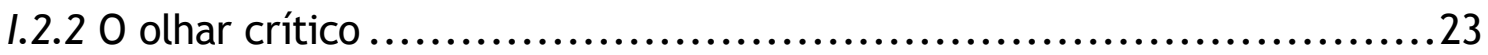

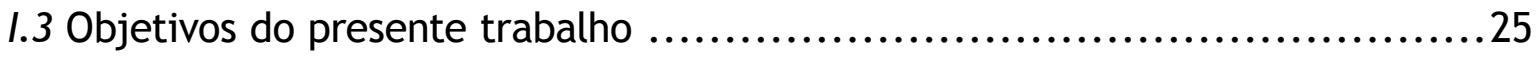

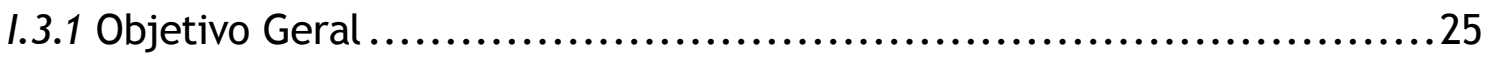

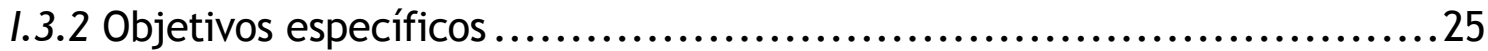

I.4 Voltando à questão de como podem ser compreendidos os registros produzidos

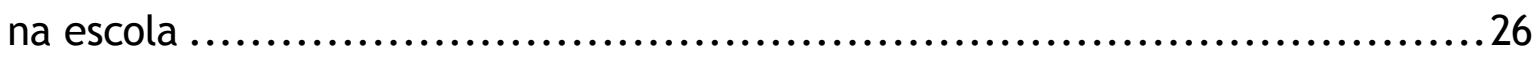

I.5 Contribuições da Educação para a compreensão dos registros escolares.......27

I.6 Publicações de autores da História da Educação ................................30

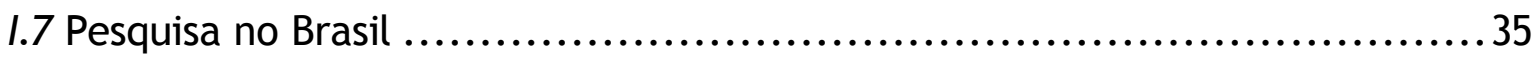

I.8 Uma mudança de foco nas pesquisas.........................................36

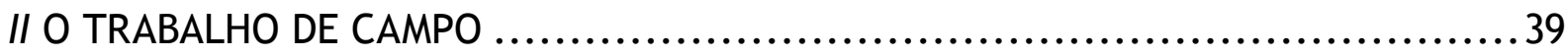

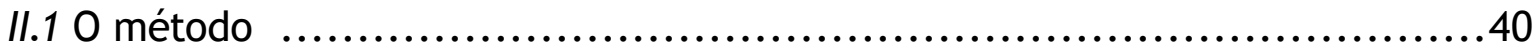

II.2 0 desenvolvimento do trabalho de campo ..................................43

II.2.1 Três momentos de entrada em campo ................................4 43

II.2.2 A etapa brasileira de obtenção de informações..........................43

II.2.2.1 A escola .......................................................... 44

11.2.2.2 As relações anteriores com a escola e com a Rede Municipal de Ensino de Hortolândia...................................................46 
II.2.2.3 A primeira série ................................................48

II.2.2.3.1 Procedimentos ........................................... 50

II.2.2.3.1.a Observações participantes ..............................50

II.2.2.3.1.b Encontros com informantes............................52

II.2.2.3.1.c Documentos: os cadernos escolares .......................53

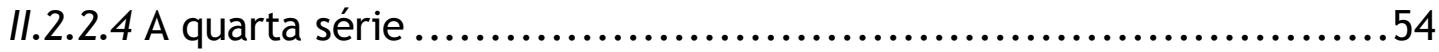

II.2.2.4.1 Os antecedentes da entrada em campo ......................54

II.2.2.4.2 As três professoras e a relação com a pesquisadora .............55

II.2.2.4.3 0 projeto Adolescer ......................................61 61

II.2.2.4.4 A sala de aula ..........................................62

II.2.2.4.5 Redefinindo o objeto de pesquisa.............................63

II.2.2.4.6 Procedimentos ...........................................6 65

II.2.2.4.6.a Observações participantes.............................65

II.2.2.4.6.b Entrevistas ..........................................68

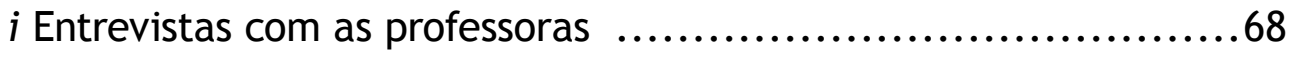

ii Entrevistas com alunos ....................................70

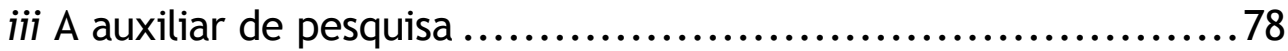

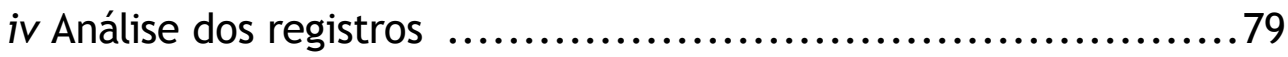

II.2.3 A etapa francesa de obtenção de informações.........................81

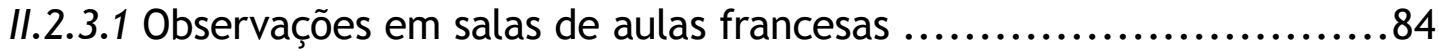

II.2.3.2 Encontros informais com professoras ..............................86

II.2.3.3 Análise dos registros........................................ 87

III OS REGISTROS EM UMA SALA DE QUARTA SÉRIE................................88

III.1 ONDE se registra? .............................................. 90

III.1.1 Os cadernos escolares ..........................................91

III.1.2 As "folhinhas" ..................................................... 93

III.1.3 Prova ........................................................ 97

III.1.4 A prevalência dos cadernos ........................................... 98

III.2 QUEM registra? .................................................... 98 


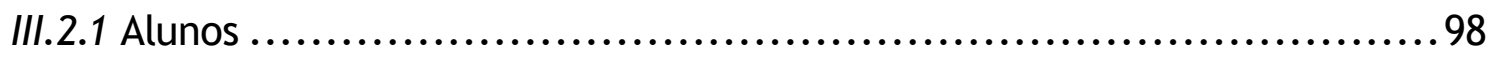

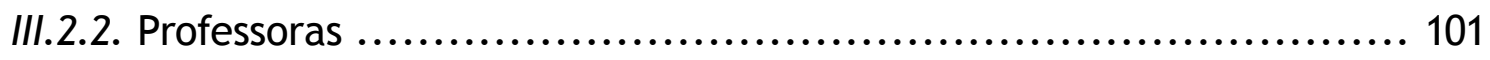

III.2.2.1 Correções................................................... 101

III.2.2.2 Trechos de exercícios........................................... 104

III.2.2.3 Bilhetes.................................................... 106

III.2.3 Família dos alunos ................................................ 106

III.2.3.1 Atividades didáticas............................................ 106

III.2.3.2 Bilhetes.................................................... 107

III.2.3.2.1 Comunicados ........................................... 107

III.2.3.2.2 Respostas aos bilhetes enviados pela escola................. 108

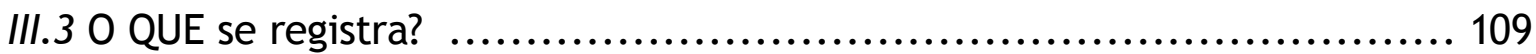

III.3.1 Conteúdos registrados pelos alunos que foram propostos pelas professoras 109 III.3.2 Conteúdos registrados por alunos independentemente de serem propostos

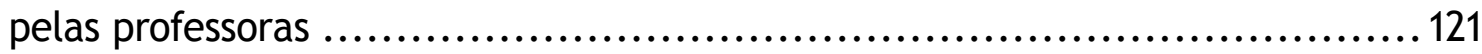

III.3.3 Conteúdos registrados pelos alunos que estão na fronteira entre o proposto e o não proposto pelas professoras .............................. 123

III.4 COMO se registra? .................................................. 124

III.4.1 As regras: seguindo e quebrando regras... ......................... 124

III.4.2 As disciplinas .................................................. 126

III.4.3 Caderno de menina e caderno de menino ........................... 128

III.4.4 A autoria: criando e repetindo as formas de fazer ......................131

III.4.4.1 A autoria nas produções de texto .............................. 133

III.4.4.2 Outras formas de autoria ......................................... 149

III.4.4.3 A repetição ..................................................... 154

III.4.4.4 Afinal, quem são os autores dos cadernos? ....................... 158

III.5 POR QUE e PARA QUE são feitos tantos registros?.......................... 159

III.6 Como, por que e para que são feitas as provas?......................... 179

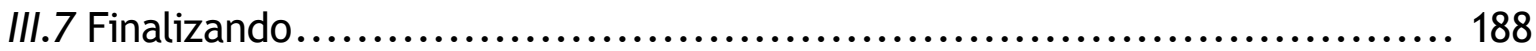

IV REGISTROS NA PRIMEIRA E QUARTA SÉRIES ................................. 190 
IV.1 Primeira série: momento de iniciação ................................. 191

IV.2 Quarta série: ampliam-se as possibilidades de criação .................... 203

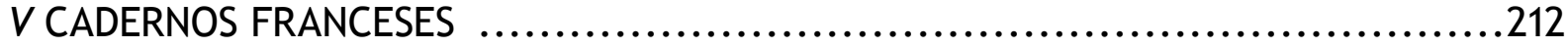

V.1 "Esse é um caderno de rascunho?"......................................212

V.2 Algumas informações sobre o contexto de ensino francês ....................213

V.3 Os cadernos como objetos .....................................................

V.4 Os primeiros aprendizados sobre os cadernos ............................. 221

V.5 0 acompanhamento docente dos cadernos ............................. 225

V.6 As regras de utilização dos cadernos..................................... 232

V.7 A divisão de cadernos ................................................. 238

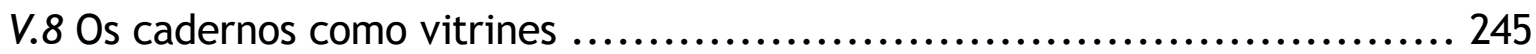

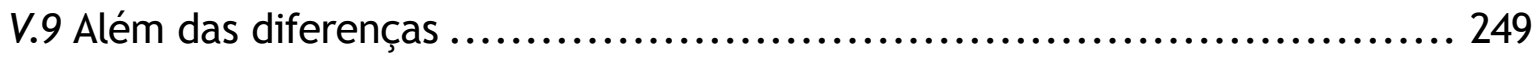

VI CONSIDERAÇÕES E PROPOSIÇÕES FINAIS ................................... 251

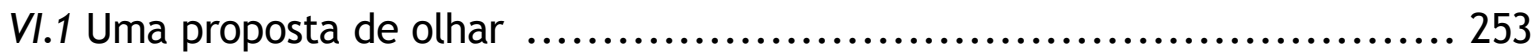

VI.1.1 Conteúdo dos cadernos ......................................... 255

VI.1.2 Conversa com o professor ........................................ 256

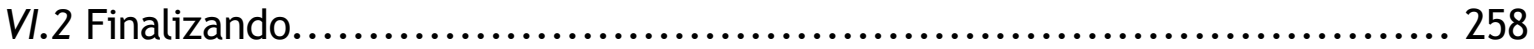

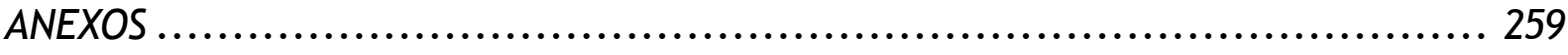

Anexo A - Relação das Observações em Sala de Aula ............................ 260

Anexo $B$ - Exemplo de Relato Ampliado .................................... 261

Anexo $C$ - Entrevista com professora ..................................... 277

Anexo $D$ - Trecho de entrevista em dupla com alunos ......................... 290

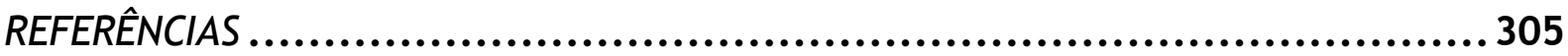




\section{INTRODUÇÃO}

O presente trabalho situa-se na interface de duas áreas do conhecimento: psicologia e educação. Os cadernos escolares e demais registros elaborados na escola, objetos eleitos como centro das atenções e reflexões aqui apresentadas, podem ser considerados relativos à área da educação, por excelência. No entanto, é por meio de um olhar oriundo da psicologia que serão abordados.

\section{I.1 COMO PODEM SER COMPREENDIDOS OS REGISTROS PRODUZIDOS NA ESCOLA?}

As atividades que os alunos realizam na escola são fortemente baseadas em trabalhos que implicam a realização de registros: cópias, exercícios, provas, produção de textos, desenhos. Ou seja, boa parte daquilo que é feito na escola resulta em algum tipo de produção gráfica.

Tais produções têm inúmeras utilidades dentro e fora dos muros escolares. Cadernos, folhas soltas e provas preenchidas por alunos possibilitam que o professor acompanhe as aquisições de saberes de seus alunos, conheça seus progressos e dificuldades, faça avaliações. Correções, assinalamentos e recados escritos nesses materiais criam possibilidades de comunicação entre professor e alunos e, por vezes, permitem também a troca de informações com as famílias. Já as provas são utilizadas para avaliar os conhecimentos adquiridos.

Os cadernos e as folhas avulsas servem para os alunos exercitarem saberes e registrarem conteúdos ministrados. Compreendem a possibilidade de revisitar aquilo que foi elaborado anteriormente, a fim de recuperar a informação ou comparar desempenho. São materiais que também se prestam a inúmeras atividades que não podem ser consideradas estritamente acadêmicas, como 
comunicação entre alunos, expressão de sentimentos, realização de desenhos e, até mesmo, a transgressão das normas escolares, como o uso de palavrões e a destruição de cadernos.

As folhas soltas tomam, com frequiência, o formato de provas. As provas, dispositivos que tempos atrás prevaleciam como instrumentos de avaliação e eram temidos pelos alunos, ganham em tempos de progressão continuada menos destaque, sem, contudo, deixarem de ser utilizadas.

Também fora da escola alguns usos são feitos desses escritos. Pais acompanham o andamento escolar de seus filhos, verificam atividades propostas pela escola. E até mesmo a justiça chega a utilizar tais documentos como provas em processos ${ }^{1}$.

Não são raras afirmações semelhantes a esta, feita por uma professora de primeira série do ensino fundamental e citada na pesquisa de Faria (1988):

No caderno a criança expressa tudo que é. Se é uma criança que tem amor, se tem capricho ao fazer as tarefas dela. Então expressa todos os sentimentos, todo o ser da criança. Pelo caderno a gente sabe o que cada um é. Até mesmo o modo de agir da criança a gente sabe pelo caderno. Se é um jeito agressivo, se é uma pessoa calma. A gente sabe porque a gente analisa até as letras. (p. 61)

No senso comum, vigora uma concepção segundo a qual, por meio dos cadernos, bem como de qualquer produção gráfica de um indivíduo, seja possível ao psicólogo realizar diagnósticos sobre características de personalidade e/ou inteligência. Dessa forma, não são raros questionamentos feitos a uma psicóloga que estuda cadernos sobre as características de uma pessoa que tem um caderno que se apresenta de determinada forma. Também não são incomuns afirmações de professores sobre a personalidade ou o nível intelectual de seus alunos realizadas com base nos cadernos.

\footnotetext{
${ }^{1}$ Como ocorreu recentemente, no final de 2004, na cidade de Nova Odessa no interior de São Paulo, quando houve a denúncia de que uma professora havia deixado seu aluno de castigo atrás da porta. O aluno foi encontrado após o encerramento das aulas. Nos cadernos dele e dos demais alunos, a comissão de sindicância avaliou as atividades e os vistos da professora, para utilizar tais informações como provas no processo. (Simionato, 2004)
} 
Certamente, esse poder diagnóstico atribuído de modo inadequado à psicologia não foi criado e nem se perpetua por ação exclusiva daqueles que o evocam e solicitam. A psicologia, em sua história, propôs-se a abstrair de produções diversas, tais como desenhos, traçado de letras ou desempenho em testes psicológicos, aspectos emocionais, psicodinâmicos e relativos à inteligência. Com os cadernos escolares, o mesmo tipo de abstração se repetiu, conforme se pode identificar em artigo publicado na revista argentina de educação, La Obra², citada por Gvirtz (1997) defendendo idéias escolanovistas ${ }^{3}$ :

0 caderno único é, em primeiro lugar, o espelho no qual se reflete a personalidade da criança. Para o professor sagaz que segue com atenção a vida espiritual de seus alunos, o caderno, na expressão constante que faz dessa vida interior da criança, é um documento muito eloqüente. (p. 61, tradução minha)

Considerando-se o poder de revelação a respeito do aluno que tem sido atribuído aos cadernos, como se poderia então compreender produções como estas?

\footnotetext{
${ }^{2}$ La Obra, vol. V, n², 1925, p. 61

3 Conforme aponta Bock (2003), a Psicologia somente passou a estabelecer uma relação forte com a Educação a partir do Movimento da Escola Nova. 0 movimento escolanovista aliou-se fortemente à psicologia, que neste momento desenvolve testes para avaliar o desempenho psicológico das crianças e passa a atender clinicamente aquelas que não apresentam o desempenho esperado pela escola. 0 trecho citado revela as influências da psicologia no pensamento educacional.
} 


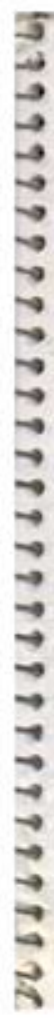

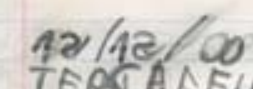

MEREAAEIRA

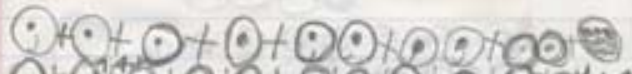
$0+0,0+0+0+0,0=0,07+1$ (1). $+\odot+\Theta+\odot+\odot e \Theta$ $8 \times 6$

$2 \times+0+0+00 \times$

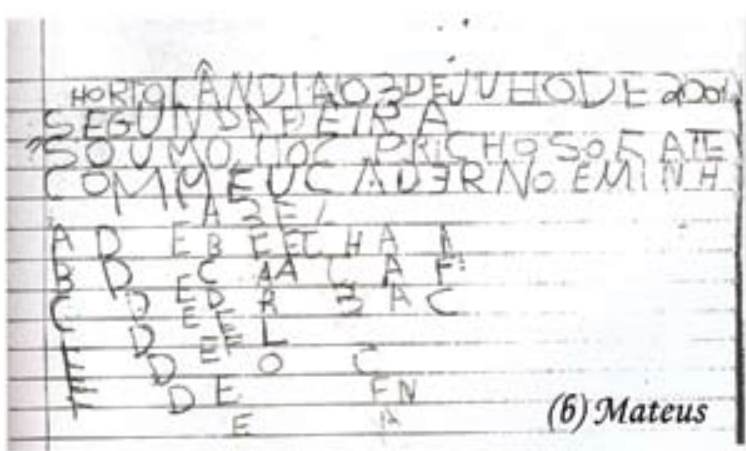

(a) Severino
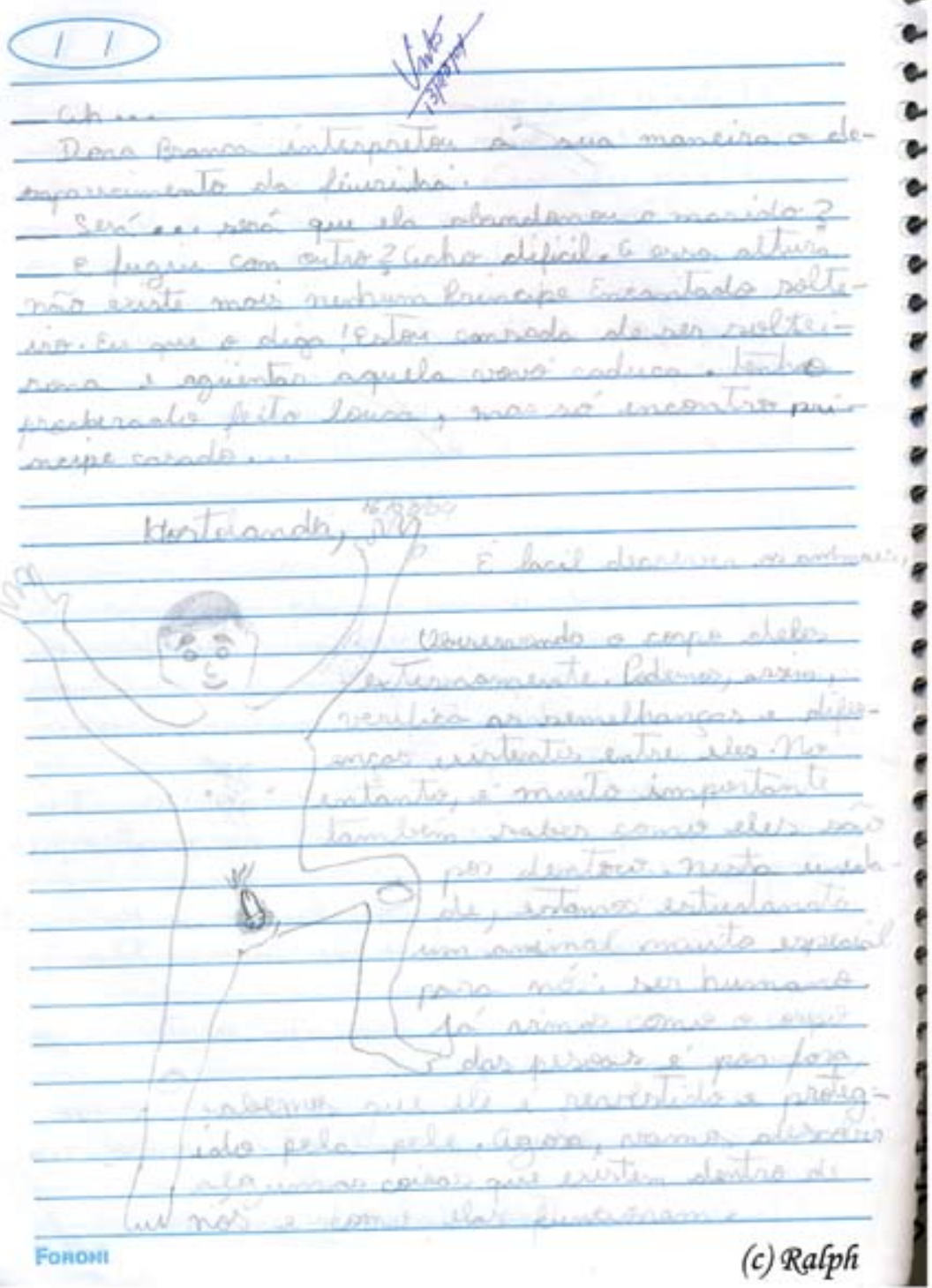

Figura 1. Produções de alunos: (a) Severino, (b) Mateus e (c) Ralph 


\section{I.2 OS OLHARES QUE A PSICOLOGIA PROPÔS PARA A COMPREENSÃO DOS CADERNOS ESCOLARES}

\section{I.2.1 OLHAR DO PSICODIAGNÓSTICO}

Os cadernos escolares não chegaram a constituir um tema ao qual a psicologia se dedicou fortemente. Podem ser encontrados apenas alguns trabalhos isolados que propõem uma compreensão psicológica desses materiais. As diferentes formas de atribuir significados aos cadernos se inserem nas diversas abordagens teóricas que a psicologia propôs em sua aproximação à área educacional.

Desse modo, os cadernos escolares foram inicialmente analisados do ponto de vista de concepções psicológicas marcadas pela psicometria, pela culpabilização do aluno e pela visão medicalizada e patologizante das questões escolares. Nessa abordagem teórica, destacam-se os trabalhos de Costa $(1983,1993)$, autora que adota o referencial teórico-metodológico da neuropsicologia e apresenta uma proposta de realização de estudo da escrita das crianças para a realização de diagnósticos neuropsicológicos, utilizando os cadernos escolares como instrumental privilegiado.

Costa (1993) pretende apresentar as vantagens da utilização dos cadernos escolares para a realização de diagnósticos neuropsicológicos, relacionados especialmente aos "distúrbios específicos da aprendizagem”. A autora identifica nesses materiais um instrumental ainda mais poderoso que o encontrado nos testes psicológicos. Enquanto os testes teriam a capacidade de detectar desvios de modo mais pontual, os cadernos, por terem informações reunidas ao longo de um período de tempo mais extenso, isto é, por apresentarem uma continuidade de produções da criança, possibilitariam identificar se algum “desvio” seria ocasional ou definitivo. Além disso, a autora alega que "a produção do caderno é natural e espontânea, excluindo assim, as possibilidades de vieses da situação de testes.” (p. 4) Ou seja, autora propõe que os cadernos escolares teriam um altíssimo potencial revelador a respeito de características intrínsecas aos alunos: 
A criança em sua rotina diária de projetar sobre o caderno, de forma exaustiva, o seu amadurecimento no plano da simbolização, projeta não apenas o resultado do aprendizado, mas como este se dá e quais as vicissitudes pelas quais ela o realiza. Ela está inteira nessa projeção e aprender a vê-la dessa forma é algo muito compensador. (COSTA, 1983, p. 4, grifo da autora)

O caderno escolar é o universo gráfico da criança, onde ela expressa todo o cabedal adquirido durante sua vida, isto é, toda a sua estruturação neuropsicológica. (idem, p. 107)

Seguindo nessa linha de raciocínio, Costa (1983) afirma que só seriam capazes de confeccionar um caderno que funcionasse como livro de estudo, ou seja, que contivesse ilustrações e os pontos abordados em aula, "aquelas crianças que possuem uma integridade das funções neuropsicológicas” (p. 107). Em trabalho posterior, Costa (1993) reafirma tal concepção, dizendo que a estabilidade afetivo-emocional é indispensável para uma boa organização da página e faz alguns acréscimos a fim de precisar em que aspectos considera o caderno revelador: "O Caderno (sic) direta e indiretamente revela aspectos relacionados com a fala, com a leitura, e até com problemas de ordem emocional." (p. 2). Além disso, a autora afirma que os cadernos podem ser uma importante ferramenta diagnóstica para a identificação de disgrafias, dislexias, afasias e discalculias, por serem "um dos registros de como o cérebro funciona." (p. 190)

Apesar de Costa (1983) considerar que “o caderno representa um importantíssimo elemento de projeção dos estados afetivo-emocionais da criança” (p. 107), ela não chega a especificar de que modo tais aspectos se manifestariam. De qualquer forma, Costa cita outra autora que aponta diretrizes para a utilização dos cadernos como base para inferências relativas ao funcionamento psíquico da criança: Antunha (1972). Antunha apresenta análises como esta: “é muito freqüente que se encontrem cadernos todos rasgados, puídos, riscados, sem capa, com orelhas, cheios de desenhos perseverativos, tudo revelando desligamento, desprezo, violência ou agressão simbólica.” (p. 157)

Assim, os cadernos escolares foram tomados com base em olhares psicodiagnósticos e interpretados como produções individuais, naturais e espontâneas 
que teriam o poder de espelhar características dos alunos. A partir de tal referencial, são compreendidos de modo descontextualizado, não considerando o conjunto de relações e regras em meio às quais tomam forma as produções escolares. Dessa forma, nesta perspectiva os cadernos poderiam ser reveladores de aspectos ligados à inteligência e ao funcionamento neuropsicológico, ou às questões afetivo-emocionais ou de personalidade.

Tais trabalhos e suas idéias, calcados numa forma de analisar e compreender os cadernos escolares, marcada por uma visão psicodiagnóstica centrada apenas na produção individual da criança, tiveram forte inserção na área educacional e fazem parte hoje do senso comum.

É pertinente observar que o modo pelo qual os cadernos foram abordados reproduz as formas pelas quais o aluno e as queixas escolares foram historicamente interpretados por determinadas concepções de psicologia. Conforme aponta Patto (1990), as idéias que ainda vigoram sobre os problemas de aprendizagem foram construídas historicamente. Primeiramente, as vertentes biológicas e da medicina se apropriaram dessa questão, com uma visão organicista das aptidões humanas. Posteriormente, no início do século XX, surgem concepções mais atentas às influências ambientais, com influências psicanalíticas.

Assim, a visão organicista, que busca as razões das dificuldades de aprendizagem em questões heredológicas e investiga distúrbios orgânicos para compreender aquilo que não vai bem na escola, comparece nas abordagens que consideram os registros dos cadernos produções “neutras” que teriam a capacidade de espelhar a "estruturação neuropsicológica" dos alunos. Também a concepção que se volta para as questões de personalidade aparece nas formas propostas para a compreensão dos cadernos, ao propor que nesses materiais sejam identificadas projeções de estados afetivoemocionais dos estudantes.

É importante considerar que as concepções psicodiagnósticas tomam os cadernos como produções individuais do aluno, seja quando os consideram um reflexo orgânico ou quando afirmam que expressam características afetivo-emocionais. 


\section{I.2.2 O OLHAR CRÍTICO}

A Psicologia Escolar/Educacional crítica surge na década de 1980 e se contrapõe a esta forma de compreensão das questões escolares, centrada ou no desenvolvimento infantil, ou nas relações familiares, ou na origem de classe social.

Tanamachi $(1997,2002)$ considera a Tese de Doutorado de Maria Helena Souza Patto $(1981)^{4}$, publicada no livro intitulado Psicologia e Ideologia: uma introdução crítica à Psicologia Escolar, em 1984, como o marco inaugural da análise crítica da área da Psicologia Escolar/Educacional, no que tange ao seu objeto de estudo, métodos e finalidades. A partir desse trabalho, começa a haver uma busca por parte de alguns psicólogos de maior aproximação à própria escola a fim de compreender os processos que ali têm origem. Ganham espaço também, a partir dessa época, as críticas na própria psicologia aos testes psicológicos e à psicometria, de modo geral (PATTO, 1990 e 1997; SOUZA, 1997, GOULD, 1999; MOYSÉS, 2001).

Assim, combasenessa abordagem teórica, foram realizadas algumas aproximações à compreensão dos cadernos escolares no processo de escolarização. Em vez de serem tomados como produções individuais dos alunos as quais teriam a capacidade de revelar características pessoais, os cadernos escolares são compreendidos como objetos produzidos no contexto escolar, em meio a um conjunto amplo de relações que inclui desde a equipe administrativa da instituição escolar e os pais de alunos, até a política educacional vigente.

Sadalla, Bariani e Rocha (1999) seguem nessa direção teórica ao apresentar um roteiro, voltado para professores e psicólogos, que busca auxiliar na observação e compreensão de materiais escolares escritos. As autoras recomendam que o material

\footnotetext{
${ }^{4}$ Trata-se da Tese de Doutorado intitulada Psicologia e ideologia: reflexões sobre a psicologia escolar, defendida no Instituto de Psicologia da Universidade de São Paulo, em 1981, sob a orientação da Profa. Dra. Ecléa Bosi.
} 
seja visto como um todo e destacam a importância de que a própria criança apresente suas produções para que tenha a:

[...] oportunidade de justificar uma série de aspectos do seu material, desde situações vivenciadas em sala de aula, bem como seus pensamentos a respeito da escola e da professora, além da dinâmica familiar em momentos de realização de lições de casa, por exemplo. (p. 172)

As autoras recomendam, ainda, que sejam observados diversos aspectos da escrita da criança, das correções da professora. Dessa forma, além de auxiliar na busca de informações sobre aluno, o material escolar contribuiria com elementos sobre a relação professor-aluno, e daria algumas informações sobre os procedimentos e metodologia de ensino utilizados pelo professor.

Destaca-se que a proposta das autoras não considera que os materiais escritos sejam reveladores por si só, por aquilo que apresentam como materialidade, mas que podem trazer informações importantes:

Deve-se ter clareza das possibilidades e limites deste tipo de análise, buscando inseri-la em um processo de avaliação que pretenda aprofundar o seu conhecimento sobre a rede de multi-determinações do processo de ensino-aprendizagem de leitura e escrita. (p. 174)

Assim sendo, os materiais escolares são tomados como produtos que, sobretudo com o auxílio daqueles que participaram de sua confecção e inseridos numa investigação mais ampla, podem auxiliar na obtenção de informações sobre processos escolares.

Também dessa perspectiva, conduzi pesquisa anterior ao presente trabalho (SANTOS, 2002), com o intuito de compreender quais eram as funções e os significados dos cadernos escolares em uma sala de aula de primeira série do ensino fundamental. Nesse trabalho foi possível identificar que há, especialmente nas séries em que se dá a iniciação escolar dos alunos, muitos aspectos do processo de ensino-aprendizagem que não são passíveis de registro nos cadernos. Desse modo, não é possível deduzir 
dos cadernos os processos que originaram determinadas produções escolares. Aspectos como as intenções do aluno, seu esforço, suas expectativas e as determinações institucionais a que está submetido o professor fazem parte dos bastidores escolares. Os efeitos da multiplicidade de fatores envolvida na realização das produções escolares comparecem nos cadernos de modos variados. 0 contexto em que os cadernos tomaram forma, porém, não pode ser abstraído unicamente dos produtos originados.

\section{I.3 OBJETIVOS DO PRESENTE TRABALHO}

O presente trabalho propõe-se a constituir um conhecimento a respeito dos cadernos escolares, tendo como referencial a Psicologia Escolar. Os objetivos são os seguintes:

\section{I.3.1 OBJETIVO GERAL}

- Constituir referenciais para a compreensão dos registros - elaborados prioritariamente pelos alunos - do ponto de vista da psicologia escolar crítica, tomando como base para tanto o conhecimento de como esses materiais se inserem nos contextos escolares e passam a fazer parte do processo de ensino-aprendizagem, do cotidiano e da cultura escolar.

\section{I.3.2 OBJETIVOS ESPECÍFICOS}

- Compreender quais são as práticas escolares por meio das quais os registros se constituem.

- Verificar qual é a natureza dos registros que são realizados.

- Caracterizar quem são os autores dos registros elaborados no contexto escolar. 
- Identificar com que objetivos os registros são feitos.

- Identificar qual é o uso que se faz, no contexto escolar, dos registros feitos.

- Conhecer aspectos dos processos de apropriação que possibilitam que os alunos elaborem tais registros.

- Estabelecer comparações relativas ao modo pelo qual são elaborados os registros por ocasião da iniciação escolar dos alunos (no caso, será considerada a primeira série do ensino fundamental) e na quarta série.

- Apresentar elementos que auxiliem na compreensão de como tais registros participam da construção das subjetividades dos alunos.

Visando responder a essas questões, foi conduzido um extenso trabalho de pesquisa de tipo etnográfico. Por meio de observações de salas de aula brasileiras e francesas, conversas com professores e alunos e análise de diversos cadernos, foi possível identificar aspectos de como os cadernos são produzidos e identificar em meio a que rede de relações e determinantes institucionais tais registros do dia-a-dia da escola tomam forma. Esses "bastidores" da construção dos cadernos são fundamentais para a constituição de elementos teórico-metodológicos que possibilitem a abordagem dos cadernos escolares numa perspectiva crítica.

\section{I.4 VOLTANDO À QUESTÃO DE COMO PODEM SER COMPREENDIDOS OS REGISTROS PRODUZIDOS NA ESCOLA}

Voltemos às figuras apresentadas no início deste capítulo (p. 19). A primeira produção pertence a um aluno de primeira série do ensino fundamental. Trata-se de uma cópia de conteúdo apresentado na lousa pela professora, que visa explicar aos alunos como funciona a multiplicação por 7. A segunda figura mostra uma tentativa de cópia de conteúdo apresentado na lousa feita por um aluno também de primeira série. A última é uma cópia de um livro didático de Ciências, realizada por um aluno de quarta série. 
Produções como essas três poderiam facilmente induzir diagnósticos que apontassem disgrafias, dislexias, discalculias, bem como questões preocupantes do ponto de vista de personalidade e/ou afetivo-emocional. Considera-se, porém, neste trabalho, que afirmações feitas unicamente baseadas nas produções dos alunos, sem que se conheça um conjunto de informações a respeito da escolarização e das condições em que tais produções ganharam forma, incorrem no risco de ser absolutamente errôneas e enganosas. Nos próximos capítulos, será possível apresentar informações a respeito de como cada uma das páginas de caderno apresentadas foi produzida e, a partir disso, abrem-se outras possibilidades de compreensão.

\section{I.5 CONTRIBUIÇÕES DA EDUCAÇÃO PARA A COMPREENSÃO DOS REGISTROS ESCOLARES}

Apesar de terem começado a ser utilizados em séculos anteriores, foi no século XX que, na América Latina, os cadernos se consagraram como instrumentos didáticos fundamentais. Desde então, passaram a constituir um material tão presente no diaa-dia das instituições de ensino que, atualmente, parece natural a utilização de cadernos. Em diversas partes do mundo, eles comparecem na lista de materiais a ser comprados pelos pais dos alunos ou, por vezes, são fornecidos pelos próprios órgãos de ensino ${ }^{5}$. Tal fato não causa espanto nem mobiliza discussões. Ou seja, a utilização dos cadernos escolares é algo que se repete sucessivamente a cada ano letivo sem que sequer se pense nisso. Dancel (2000) se refere a esse fenômeno da seguinte forma: "O caderno faz parte daqueles objetos que se tornam invisíveis por força de serem naturalmente presentes nas listas de material a comprar na volta às aulas, nas frases das instruções, nas mochilas dos alunos." (p. 121, tradução minha)

O fato de os cadernos não serem objetos de discussão nas escolas repetiuse, durante muitos anos, nas produções acadêmicas e publicações. Ainda que os

\footnotetext{
${ }^{5}$ Foi possivel encontrar, ao longo do presente trabalho de pesquisa, listas de materiais brasileiras, norte-americanas e francesas. Em todas elas, os cadernos escolares estão presentes.
} 
cadernos escolares se caracterizem por serem objetos que participam de modo determinante de vários processos que se dão nas escolas, chama a atenção a raridade com que apareciam nas publicações da área de educação até a década de 1990. Será apresentado a seguir um apanhado das publicações encontradas sobre o tema.

Defodon, em uma publicação francesa de 1887 intitulada Dictionnaire de Pédagogie et d'Instruction Primaire, define o verbete cahiers ${ }^{6}$ da seguinte forma: "uma coleção de um certo número de folhas de papel unidas e cosidas, de que os alunos se servem para escrever os deveres diários que lhes são dados pelo professor" (p. 302, tradução minha). A essa definição se segue uma série de apontamentos sobre a materialidade desses objetos: a qualidade do caderno e do papel usado em sua confecção, avaliações sobre as capas mais adequadas - aquelas que, de um lado, apresentam uma nota histórica e, de outro, um mapa da cidade, monumentos, curiosidades e lugares mais importantes da França. Por fim, é apresentada uma defesa da utilização do caderno único nas escolas.

Se, na França, os cadernos passaram a ser instrumentos comuns dos alunos de colégio desde o século XVI (HÉBRARD, 2001), Gvirtz (1997) relata que na América Latina, até o século XIX, o papel era um artigo de luxo, importado, ou seja, um recurso muito caro para o trabalho escolar. Por isso, o papel era reservado aos estágios mais avançados da escolaridade. Em vez de papel, eram utilizadas lousas manuais. A substituição dessas lousas pelos cadernos escolares mobilizou diversos autores argentinos ${ }^{7}$, que se dedicaram a escrever a respeito de qual seria o suporte mais adequado para o desenvolvimento das atividades escolares.

A presença maciça dos cadernos nas escolas atuais revela que a utilização deles cadernos realmente passou a ser predominante ${ }^{8}$, após uma polêmica que perdurou até a década de 1920. Alguns anos depois, outra polêmica volta a envolver os cadernos,

\footnotetext{
${ }^{6}$ Cahiers significa "cadernos", em francês.

7 Gvirtz (1997) cita diversos trabalhos publicados na revista La Obra, entre os últimos anos do século XIX e início do século XX que se dedicam a esta questão.

${ }^{8}$ As lousas manuais mantiveram-se, por exemplo, na França. Nas escolas francesas de ensino elementar, as atividades de matemática são prioritariamente desenvolvidas em pequenas lousas, chamadas de ardoises, em vez de em cadernos.
} 
conforme relata Gvirtz (1997, 1999): a utilização do caderno único. Em um momento no qual, segundo o relato da autora, a utilização de diversos cadernos havia se tornado corrente, o Movimento da Escola Nova passa a defender fortemente que haja um único caderno no qual o aluno faça todos os exercícios e trabalhos escolares. Tal defesa proporcionou que o assunto fosse, por diversas vezes, mencionado nas publicações escolanovistas. Gvirtz $(1997,1999)$ destaca que a revista argentina La Obra tratou do assunto em diversos números ${ }^{9}$ publicados na década de 1920. Alguns artigos descreviam como deveria se dar a utilização do caderno único, sempre destacando as vantagens da adoção desse recurso didático: reunir a obra pessoal da criança na aula; auxiliar a criança a adquirir "normas da vida"; possibilitar o controle do trabalho docente e do trabalho dos alunos, facilitando o trabalho dos diretores por serem documentos que permitiriam expor e conservar os conteúdos efetivamente transmitidos pela escola.

Enquanto as primeiras décadas do século XX se caracterizam pelas publicações em defesa do uso dos cadernos e de prescrições sobre como utilizá-los na prática pedagógica, nas últimas décadas, e sobretudo nos últimos anos, intensificaram-se os trabalhos dedicados à compreensão dos cadernos e dos registros que neles podem ser encontrados. Os trabalhos sobre esse tema passaram a adotar formatos diversos. Além dos livros e das demais publicações acadêmicas, voltadas para um público restrito de interessados na área de educação, surgem na França publicações de grande tiragem destinadas ao público em geral ${ }^{10}$. São livros que exibem primordialmente belas fotos de cadernos de épocas diversas. Apresentam também breves textos que analisam as características dos materiais e as mudanças ocorridas ao longo do tempo.

Entre os trabalhos acadêmicos sobre o tema, existem diversas pesquisas conduzidas por pesquisadores da História da Educação que têm os cadernos como tema. Algumas delas utilizam esses materiais como fontes de informação para a

\footnotetext{
${ }^{9}$ La Obra, Revista quincenal de Educación. Vol. V, nos 1, 2 e 3. Vol. VI, nos 1 a 5, Vol. VII, nos 2 a 7 , Buenos Aires.

10 Nesta categoria de publicações, é possível citar: Bukiet e Mérou (2000) que reuniram cadernos de 1870 a 2000 e Grunstein, Pecnard e Dancel (2002) que apresentam cadernos de 1880 a 1968 . Vale destacar que a última publicação se encontrava, em final de 2005, em lugar de destaque em grandes livrarias de Paris e era vendida em preço promocional.
} 
realização de pesquisas históricas (HUBERT E HÉBRARD, 1979; GVIRTZ, 1997, 1999; CHARTIER e RENARD, 2000; CHARTIER, 1999, 2000, 2002, 2002-2003, 2003, 2005; DANCEL, 2000; HÉBRARD, 2001, VIÑAO, 2006). As publicações que puderam ser encontradas foram escritas em dois idiomas, francês e espanhol, e são oriundas da França, Argentina e Espanha.

\section{I.6 PUBLICAÇÕES DE AUTORES DA HISTÓRIA DA EDUCAÇÃO}

O trabalho de Hubert e Hébrard (1979), publicado no final da década de 1970, foi o primeiro trabalho encontrado que adota a perspectiva de compreender de que forma se dá a inserção dos cadernos no contexto escolar e como estes participam da configuração do trabalho pedagógico. Os autores analisaram as modificações ao longo do tempo nos conteúdos dos cadernos, abrangendo cadernos utilizados durante um período de aproximadamente um século, começando por exemplares das últimas décadas do século XIX. Identificaram que nesse período o exercício passou a predominar nos cadernos e afirmam que, no momento em que o exercício se torna o centro do trabalho escolar, o caderno não é apenas um suporte, mas também um instrumento que dá ao trabalho escolar a sua verdadeira significação. Assim, alegam que os cadernos são as principais testemunhas do trabalho escolar. Concluem dizendo que, por meio do exercício, a escola primária utiliza sua concepção de saber para dar uma forma homogênea ao trabalho escolar: um saber sem lacunas, elementar, mas que tem uma qualidade de completude.

Gvirtz $(1997,1999)$ desenvolveu um grande trabalho de pesquisa com cadernos argentinos, buscando distâncias e aproximações entre aquilo que é proposto como currículo oficialmente e o currículo que é praticado nas escolas. Para isso, foram analisados 781 cadernos do século XX, abrangendo desde a década de 1930 até a década de 1980. Eram cadernos provindos de escolas públicas e particulares, relativos às sete primeiras séries de escolarização. 
Gvirtz realiza um exaustivo trabalho de descrição e análise das características dos cadernos estudados. Por agora, serão destacados os aspectos considerados mais relevantes para o presente trabalho. Teoricamente, Gvirtz traz uma importante contribuição. Recorrendo a um referencial foucaultiano, propõe que os cadernos sejam considerados dispositivos ${ }^{11}$, ou seja, "um conjunto de práticas discursivas que se articulam de um determinado modo, produzindo um efeito." (p. 25, tradução minha). Apesar de não se alongar na explicitação de como o caderno é tomado teoricamente como dispositivo, Gvirtz (1997) ressalta que seu ponto de vista teórico implica que o caderno não seja tomado como "sintoma ou manifestação de questões ocultas e secretas" (p. 25), mas, como "conjunto de sinais que se articulam e entrelaçam de modo particular enquanto práticas discursivas" (p. 25). E é em busca das práticas discursivas escolares que a autora se dedica ao estudo dos cadernos escolares, classificados como fontes primárias de acesso àquilo que foi ensinado. É importante destacar que a autora classifica os cadernos como "uma das formas privilegiadas de registro do ensino e, em alguns poucos casos, da aprendizagem" (p. 22). Ou seja, mais do que revelar sobre o aluno, suas capacidades e aquisições escolares, os cadernos poderiam revelar sobre o ensino, sobre aquilo que foi efetivamente ensinado e sobre as tarefas escolares propostas:

O caderno [é] um espaço de interação entre professores e alunos, uma arena onde cotidianamente se enfrentam os atores do processo de ensino-aprendizagem e onde, por isso, é possível vislumbrar os efeitos desta atividade: a tarefa escolar. (p. 23, tradução minha)

A autora considera o caderno um produtor de saberes escolares. Há saberes cujo domínio passa a ser necessário em razão da utilização dos cadernos escolares. 0 aluno que utiliza o caderno deve conhecer conceitos como capa e margem, precisa respeitar a sucessão espacial das folhas, a sucessão temporal das tarefas. " $O$ caderno que parece operar como contexto acaba por contribuir na formação do texto." (p. 26). Assim, a

\footnotetext{
${ }^{11}$ A mesma classificação teórica será utilizada, pouco tempo depois, por Anne-Marie Chartier (1999). Essa autora francesa apresenta uma análise teórica mais detalhada de como os cadernos se tornam e agem como dispositivos escolares.
} 
utilização do caderno não é neutra, traz elementos ao contexto educacional. A autora aponta que o modo pelo qual as disciplinas se estruturam nos cadernos escolares, por meio de trabalhos e exercícios, ressignifica os saberes científicos.

Se a escola primária, ao ensinar, oferece uma gama considerável de possibilidades operativas com um universo simbólico (pode-se classificar, decompor, analisar, resolver, definir etc.), a ciência possui outros parâmetros e outras pautas de descrição e interpretação. (p. 85, tradução minha)

Anne-Marie Chartier ${ }^{12}$ é outra importante pesquisadora que tem tomado os cadernos escolares como objeto de estudo. Desde 1999, vem publicando artigos que tomam os cadernos escolares tanto como fontes de informação, quanto como objetos cuja utilização, bem como os efeitos dessa utilização, devem ser conhecidos.

No primeiro trabalho publicado sobre o tema, Chartier (1999) descreve de que modo cadernos e fichário se tornam dispositivos, no sentido proposto por Foucault (2001): uma rede heterogênea, na qual se encontram entrelaçados "discursos, instituições, estruturas arquiteturais, decisões regulamentares, leis, medidas administrativas, enunciados científicos, proposições filosóficas, morais, filantrópicas, em suma: o dito tanto quanto o não-dito." (p. 299, tradução minha). A autora prossegue ilustrando e exemplificando como os suportes de escrita se constituem em dispositivos no contexto escolar. Destaca que, para um dispositivo funcionar, precisa ser assimilado pela instituição, ou seja, é necessário que seja permanentemente praticado.

Um dispositivo assimilado é, portanto, uma realidade interior tanto quanto exterior, subjetiva tanto quanto objetiva, representada tanto quanto instituída. Fala-se dele sem que se pense nele. (p. 210, tradução minha)

Assim, os cadernos estão tão associados ao funcionamento escolar que mal se pode cogitar uma escola que não os adote.

12 Pesquisadora francesa, Maître de Conférences do Service d'Histoire de l'Éducation do Institute National de Recherche Pédagogique (INRP). Durante o período de preparação desta tese de Doutorado, tive a oportunidade de realizar um estágio sob sua supervisão. 
A autora relata (CHARTIER 1999, 2001, 2002-2003) eventos ocorridos em uma pesquisa desenvolvida pelo INRP sobre a polivalência dos professores primários para compreender como se dava a utilização dos cadernos. A fim de recolher produções dos alunos sem recorrer às fotocópias, as pesquisadoras propuseram que a cada dia uma criança diferente realizasse suas atividades em um "caderno de rodízio", em vez de utilizar os seus próprios materiais. Esse "caderno de rodízio", após ser devidamente corrigido, seria entregue aos pesquisadores.

Em geral, na França, os alunos trabalham com uma grande variedade de cadernos, divididos tanto por disciplinas quanto pelo modo de utilização ${ }^{13}$. Isso faz com que seja necessária a aprendizagem, difícil e custosa, de qual caderno deve ser utilizado para cada atividade. Inicialmente, imaginou-se que a mudança de suporte de escrita proposta pela pesquisa não seria muito perturbadora do trabalho escolar, afinal tratava-se de utilizar um único caderno. No entanto, muitos alunos apresentaram dificuldades e hesitações em razão da situação inédita em que se encontravam. As dificuldades encontradas pelos alunos, ao terem que trabalhar com um suporte de atividades de escrita organizado de modo diferente do habitual, foram bastante reveladoras. Seguindo a determinação: “Hoje, tudo o que vocês habitualmente escrevem nos seus cadernos, vocês vão escrever no caderno novo." (CHARTIER, 1999, p. 212), os alunos repetiram a escrita da data no alto da página a cada mudança de disciplina e, por fim, anotaram no caderno de rodízio os exercícios que deviam preparar para a semana seguinte. A confusão das crianças revela a respeito dos diferentes modelos de utilização de cadernos: o uso de um único caderno ou de um conjunto deles. A forma como se dá a organização das atividades escolares em suportes de escrita imprime peculiaridades ao trabalho dos alunos.

Ao acompanhar o dia-a-dia das escolas, a autora identificou o quanto a divisão dos cadernos em disciplinas, tal como ocorre na França, ensina aos alunos como se dividem os saberes (CHARTIER e RENARD, 2000; CHARTIER, 2001, 2002-

\footnotetext{
13 Para maiores esclarecimentos a respeito da utilização e divisão de cadernos na França, consultar o Capítulo V - Cadernos Franceses. Os alunos da sala em questão estavam acostumados a trabalhar com nove cadernos e dois fichários. Um dos fichários, o de Francês, era dividido em sete partes. 0 fichário de matemática, por sua vez, era dividido em três partes.
} 
2003, 2005). Ou seja, a partir de um determinado conjunto de tarefas agrupadas em torno do título "gramática", as crianças constroem uma representação sobre essa área de conhecimento. 0 conjunto de atividades realizadas nos cadernos, além disso, mostra aos alunos quais são os saberes escolares legítimos. Como aponta a autora, todos os alunos da França (assim como os alunos brasileiros) sabem que não há nenhuma disciplina que se chame Cinema, por exemplo. Por meio do uso dos cadernos, as crianças também aprendem que existe uma hierarquia entre as disciplinas. Matemática, por exemplo, aparece como uma disciplina evidentemente mais importante, afinal é uma das disciplinas cujos fichários são mais utilizados e corrigidos. Enquanto isso, a Educação Física, que não deixa traço algum registrado, é vista como menos importante.

Outro trabalho sobre o tema (CHARTIER e RENARD, 2000) foi fruto da análise de um questionário sobre os suportes de ensino utilizados em sala de aula, respondido por 87 professoras de École Elementaire ${ }^{14}$. Baseadas em uma compreensão sobre os tipos de suportes utilizados (cadernos ou fichários) e sobre as divisões adotadas (divisões em disciplinas, subdivisões dentro de uma mesma disciplina), as autoras retomam a idéia segundo a qual a utilização de suportes de escrita adotada ${ }^{15}$ compõe a representação que os alunos fazem das disciplinas. Ressaltam ter encontrado muitos comentários de professores sobre "pôr em ordem", sobre "o temor da desorganização" e sobre "a necessidade de pôr as coisas em seu lugar". As autoras interpretam que para os professores a desorganização de cadernos e fichários refletiria a desordem que os alunos teriam em suas cabeças. E assim, como aponta Chartier (2001), os procedimentos de organização do trabalho escolar teriam a função de favorecer, de forma implícita e eficaz, que os alunos fizessem categorizações cognitivas dos saberes escolares.

Tais estudos a respeito dos cadernos e o modo pelo qual se dá a realização dos registros indicam que esses modestos materiais escolares podem ser tratados como

${ }^{14}$ Consultar tabela comparativa dos sistemas de ensino brasileiro e francês na seção II.2.3. A etapa francesa de obtenção de informações do Capítulo II.

15 Uma descrição mais detalhada sobre o modo pelo qual se dá a organização dos suportes de escrita na França será apresentada mais adiante, no Capítulo V intitulado Cadernos Franceses. 
verdadeiros dispositivos de aculturação (CHARTIER, 2001). O ritual de preencher os cadernos seguido diariamente pelos alunos resulta em registros que revelam normas e valores que vigoram na cultura escolar em que estão inseridos (CHARTIER, 2002-2003).

Há novas pesquisas em curso, como o projeto de doutorado de Colotta (2005) ${ }^{16}$ que pela análise de cadernos escolares espanhóis e argentinos pretende compreender a inserção dos alunos na cultura escrita. A continuidade dos estudos certamente contribuirá para que, em breve, possamos dispor de um conjunto mais amplo de informações que auxiliem na compreensão de como os cadernos escolares se inserem no contexto escolar.

\section{I.7 PESQUISA NO BRASIL}

No Brasil, destaca-se um trabalho de pesquisa desenvolvido por Faria (1988), em Minas Gerais, que constitui a vanguarda brasileira no tema, como evidencia a autora ao final de sua dissertação de mestrado:

Muitas foram as limitações encontradas para o desenvolvimento deste trabalho. A maior delas foi, sem dúvida, a inexistência de estudos, em nosso país, a respeito do caderno escolar. (p. 250)

Faria analisou cadernos de 11 crianças da primeira série do ensino fundamental, alunas da rede pública de ensino. Faria afirma que: "os cadernos (...) constituem as provas mais evidentes do trabalho que se desenvolve na escola." (p. 4). Ao dizer isso, a autora refere-se ao trabalho pedagógico e intitula seu trabalho de "No caderno da criança o retrato da escola":

${ }^{16}$ Pesquisador argentino que atualmente desenvolve sua pesquisa na Universidade de Alcalá de Henares, na Espanha. 
A meu ver, os registros produzidos no caderno são a expressão concreta do pensamento do professor ou da escola, na medida em que são a instância pensada e planejada do trabalho desenvolvido na sala de aula. (p. 5)

Diferentemente dos trabalhos da psicologia anteriormente citados, Faria não considera que o caderno tenha forte potencial revelador a respeito do aluno. Afirma, inclusive, que apresentam uma falsa imagem do desenvolvimento da criança. Alega ter encontrado em sua pesquisa muitos cadernos que não tinham os alunos como autores. A autora considera que, para que a criança seja autora, é necessário que ela possa registrar conteúdos relacionados às suas experiências de vida. Em outros cadernos, era possível encontrar marcas da linguagem e da cultura das crianças. Assim, conclui: "o caderno era, na realidade, o retrato da escola e da prática pedagógica que ali se desenvolvia." (p. 188)

\section{I.8 UMA MUDANÇA DE FOCO NAS PESQUISAS}

Mas por que os cadernos escolares se tornaram objeto da atenção dos pesquisadores nos últimos anos? Se os cadernos escolares são largamente utilizados nas escolas há tanto tempo, por que há apenas 30 anos começam a surgir publicações que se propõem a compreender como se inserem e o que promovem no contexto escolar? Por que os esforços de compreensão desses suportes se intensificaram sensivelmente a partir da década de 1990 ?

Gvirtz (1997) atribui essa tendência à Nova Sociologia da Educação britânica, que teve sua publicação inaugural em 1971. A partir daí teria se dado o início de investigações que buscaram romper com a "caixa preta" da escola, passando a "analisar os processos de produção, seleção, organização, transmissão e apropriação do conhecimento dentro da escola" (p. 21).

Aexpressão ‘caixa preta’ também é utilizada por Caspard, em 1988, na introdução da revista Histoire de L'Éducation sobre a história das disciplinas escolares. Nesse 
texto (CASPARD, 1988), o autor refere-se ao fato de que a história da educação se tenha dedicado pouco ao conteúdo do ensino, privilegiando até então o estudo de debates políticos e ideológicos. Como superação dessa lacuna, defende o uso de instrumentos de pesquisa que possibilitem o acesso àquilo que realmente ocorreu nas salas de aula, tais como cadernos, cópias e trabalhos escolares de outros tipos. Os registros feitos pelos estudantes possibilitam confrontar o ensino desejado, planejado e proposto pelas teorias pedagógicas com o que efetivamente é praticado nas escolas (CHARTIER, 2003).

Chartier (2000) também se refere à importância de que as pesquisas em educação se voltem para "o que se faz na escola" (p. 158). Conhecer os fazeres ordinários da escola é algo que, além de revelar aspectos importantes e pouco conhecidos sobre a educação, tem um papel essencial na formação de jovens professores. Desse modo, a autora chama atenção para a importância de conhecer as práticas do ofício de professor para que tais saberes constituam o conjunto de conhecimentos abordados na formação inicial de futuros professores.

Viñao (2006), em busca de compreender os múltiplos olhares históricos que têm nos últimos anos se voltado para os cadernos escolares, atribui o interesse por esse objeto de pesquisa a movimentos oriundos de diversas áreas. Na história da educação, a atenção aos cadernos foi um modo de se aproximar das práticas escolares, do dia-a-dia das salas de aula. A história da cultura escrita passou a manifestar um interesse crescente pelas produções escritas cotidianas e ordinárias e, assim, passou a incluir os cadernos entre seus objetos de estudo. A história da infância também tem recorrido aos cadernos como uma forma de aproximação da criança por meio do que ela produz, em vez de utilizar os discursos e as produções adultas sobre a infância.

Seria pertinente acrescentar uma área de conhecimento não citada pelo autor: a psicologia escolar. Conforme foi mencionado, a psicologia se voltou para os cadernos baseada em diferentes referenciais teóricos. No caso da psicologia escolar crítica, o interesse pelos cadernos surge como uma forma de aproximação das relações, dos meandros institucionais que compõem a escola e do modo pelo qual o aluno - o 
proprietário e importante autor do caderno - vivencia seu processo de escolarização. Os cadernos e demais registros tornam-se materializações de algo que ocorre na escola e, por isso, podem ser importantes instrumentos no trabalho do psicólogo. No entanto, a compreensão desses documentos é complexa e, por vezes, capciosa. Em busca de melhor compreender os cadernos e demais registros elaborados na escola, do ponto de vista da psicologia escolar crítica, foi conduzido o estudo que será apresentado nos próximos capítulos. 


\section{O TRABALHO DE CAMPO}

A realização de registros ocupa boa parte do tempo escolar dos alunos. Copiar da lousa, produzir textos, resolver problemas, preencher avaliações são atividades que descrevem muito daquilo que as crianças realizam quando estão na escola. Muito além de envolverem apenas os alunos, tais produções articulam os diversos atores envolvidos no processo ensino-aprendizagem. Na produção dos registros, no dia-a-dia das escolas, comparecem dimensões individuais, institucionais e sociais.

A Psicologia Escolar tem caminhado teoricamente a fim de aproximar-se do que ocorre dentro dos muros escolares, abandonando interpretações que individualizam - seja no aluno e sua família, seja no professor - as razões para o fracasso escolar e buscando uma compreensão ampla das questões escolares em suas múltiplas determinações. É no bojo dessa forma de compreender o objeto da Psicologia Escolar que foi conduzida a presente pesquisa que propõe aproximar-se dos cadernos escolares para compreender aspectos do contexto escolar.

Os alunos, aqueles que mais diretamente executam os registros estudados, são parte importante desse contexto. A realização das atividades escolares, bem como o modo pelo qual suas produções são recebidas pelos adultos, compõe o modo pelo qual os alunos se reconhecem, contribuindo para formar sua auto-imagem.

Como aponta Tanamachi (2000), a Psicologia é uma ciência que busca explicar como a partir do mundo objetivo (que é histórica e socialmente determinado) se constrói o mundo subjetivo do indivíduo. Assim, conhecer mais sobre como se dá a produção dos registros pelos alunos acrescenta elementos à compreensão das subjetividades construídas por meio das possíveis experiências escolares.

Em busca de compor um conjunto de informações que auxiliassem a responder às indagações apresentadas, foram feitos estudos em salas de aulas. Assim, o presente trabalho é resultado da análise de informações obtidas em três contextos distintos. Foram realizados três inserções em campo para a obtenção de informações a respeito 
dos cadernos escolares. Duas delas se deram no Brasil, em salas de aula de primeira e quarta série, e a última ocorreu em escolas francesas.

\section{II.1 O MÉTODO}

Para conhecer como os registros escolares elaborados prioritariamente pelos alunos se inserem e passam a fazer parte do processo do contexto escolar, fez-se necessário adotar uma abordagem teórico-metodológica que implicasse uma imersão no que ocorre no dia-a-dia da escola. A perspectiva etnografia foi eleita como a opção mais adequada e coerente.

A etnografia caracteriza-se por implicar uma longa convivência do pesquisador com o contexto pesquisado. Tal maneira de fazer pesquisa é oriunda da antropologia e surgiu como uma forma de conhecer culturas e sociedades que não eram as do pesquisador. 0 modo de pesquisar etnográfico foi adotado e adaptado por outras áreas do conhecimento, tais como a educação e a psicologia. André (1995) ressalta que, ao fazer as adaptações necessárias às especificidades de cada área do conhecimento, a pesquisa deixa de ser etnografia para tornar-se de tipo etnográfico.

Ainda que a pesquisa de tipo etnográfico em Psicologia Escolar se distancie em alguns aspectos - tais como o modo de permanência em campo e duração do tempo de convivência - da etnografia original, mantêm-se os princípios básicos. Assim, como aponta Geertz (1989), adota-se um tipo de aproximação de uma determinada cultura a fim de interpretá-la, de buscar as significações que atos, ritos, costumes, idéias e objetos adquirem em um determinado contexto, para aqueles que nele vivem.

Fazer etnografia é como tentar ler (no sentido de "construir uma leitura de"), um manuscrito estranho, desbotado, cheio de elipses, incoerências, emendas suspeitas e comentários tendenciosos. (p. 7)

Também caracteriza o trabalho de cunho etnográfico a produção de um texto descritivo - chamado por Geertz (1989) de "descrição densa" - que tem como intenção 
a explicação de uma trama de significações que constitui uma determinada cultura. Geertz (1989) afirma que “a etnografia é descrição densa” (p. 7). Outros autores se referem à etnografia como o processo de "documentar o não documentado" (ROCKWELL, 1987).

A realização de um trabalho com tais pretensões exige uma inserção bastante intensa no contexto pesquisado. Como bem detalha Rockwell (1987), cabe ao pesquisador estar junto do contexto pesquisado, participar dele, observar o cotidiano, conversar com as pessoas a respeito do que vivem, ou seja, realizar uma observação participante. E, além disso, é necessário manter um cuidadoso registro escrito das informações obtidas. A permanência em campo e a convivência com as pessoas possibilita algo fundamental para, realmente, conhecer uma cultura: estabelecer relações de confiança com os informantes. Bosi (2003) aponta que da qualidade do vínculo depende a qualidade das conversas que podem ser estabelecidas. Os momentos de diálogo com os participantes da pesquisa são momentos privilegiados para checar informações e hipóteses que o pesquisador vai formulando à medida que prossegue o trabalho de campo (ROCKWELL, 1987; ANDRÉ, 1983).

Estar em campo, dentro de uma sala de aula - especialmente quando se trata das escolas públicas brasileiras, com todas as dificuldades que perpassam esses espaços educacionais -, traz vários impasses ao pesquisador. Ao conviver, ao longo de um ano, com uma sala de aula, é possível acompanhar as conquistas de alunos e professores, bem como conhecer suas potencialidades. No entanto, também as fragilidades do trabalho desenvolvido ficam expostas. O dia-a-dia das escolas pode despertar sentimentos diversos no pesquisador; dentre muitos outros, empatia, revolta, indignação e admiração podem ser citados. Os julgamentos a respeito daquilo que se vive e presencia chegam a ser quase inevitáveis em alguns momentos. É por isso que a recomendação de suspender os julgamentos (BECKER, 1999) exige um esforço constante. Afinal, julgar em nada colabora para que o pesquisador se aproxime de uma compreensão do modo pelo qual a realidade social estudada e vivida é percebida pelos que dela fazem parte. 
Em vez de julgar, é preciso compreender os atos e eventos no contexto em que ocorrem. Geertz (1989) nos chama a atenção, em suas análises para a importância de considerar conjuntamente fatores psicológicos, materiais e sociais para realmente compreender uma cultura. Quando um fator é tomado isoladamente, há riscos de incorrer em sérios erros de análise. Assim, ao compreender procedimentos de alunos ou professores, bem como fatos ocorridos na escola, é preciso contextualizá-los ao máximo. Buscar suas determinações nos mais variados âmbitos. Tal esforço é fundamental para que não se recaia nas explicações simplistas que culpabilizam o professor pelo fracasso escolar dos alunos.

A construção do texto também requer cuidados e atenção. É fundamental fornecer ao leitor uma gama de informações, tais como trechos de diálogos ou anotações de campo, bem como reproduções de documentos, que possibilitem que ele compreenda como o pesquisador formulou argumentações e chegou a conclusões. Além disso, é com base em tais elementos que se materializa uma das principais contribuições da utilização dos referenciais teórico-metodológicos da etnografia na Psicologia Escolar: permitir que as crianças, seus pais e os educadores possam imergir como sujeitos da própria história (SOUZA, 2004).

Outro aspecto do texto etnográfico é que ele é construído pela observação participante do pesquisador, ou seja, pelo contato pessoal e estreito com o fenômeno pesquisado (LÜDKE E ANDRÉ, 1986). Assim, é por meio da experiência do pesquisador com o contexto que vai se formando a possibilidade de compreender, interpretar e descrever. 0 pesquisador está em campo por inteiro, com suas concepções teóricas, sentimentos e valores. Assim, considerou-se que, para a descrição do campo, a utilização da primeira pessoa do singular seria mais compatível com a profundidade da inserção em campo necessária para a realização do trabalho de pesquisa.

Certamente conduzir um trabalho de pesquisa regido pelos princípios que foram apresentados é um desafio, desafio que foi aceito pela pesquisa que será apresentada a seguir. 


\section{II.2 O DESENVOLVIMENTO DO TRABALHO DE CAMPO}

\section{II.2.1 TRÊS MOMENTOS DE ENTRADA EM CAMPO}

Em busca de compor um conjunto de informações a respeito da realização de registros em sala de aula, foram conduzidas três inserções em campo.

A primeira ocorreu por ocasião da realização da pesquisa que deu origem à dissertação de mestrado sobre os cadernos escolares, intitulada Cadernos escolares na primeira série do ensino fundamental: funções e significados (SANTOS, 2002). Nesse momento, em 2000, acompanhei todo o ano letivo de uma sala de aula de primeira série de ensino fundamental, em escola municipal da cidade de Hortolândia.

A segunda inserção em campo deu-se na mesma escola e consistiu no acompanhamento do ano letivo de uma quarta série do ensino fundamental, em 2004.

Por fim, em 2005, ao longo de dois meses e meio, foram realizadas observações em salas de aulas de escolas francesas.

Nas próximas seções, serão detalhados cada um desses três momentos de entrada em campo.

\section{II.2.2 A ETAPA BRASILEIRA DE OBTENÇÃO DE INFORMAÇÕES}

As duas primeiras etapas do trabalho de campo compõem o conjunto mais denso de informações. A extensão da permanência em campo em cada uma das etapas - um ano letivo - possibilitou que fosse empreendida, efetivamente, uma pesquisa de tipo etnográfico.

A proposta de acompanhar a primeira e a quarta séries, ou seja, o início e o encerramento da primeira etapa do ensino fundamental, permitiu conhecer aspectos importantes desses quatro anos de escolarização. Como se dá a iniciação 
na utilização de cadernos e na realização de registros? Quais são as diferenças e as semelhanças entre os modos de registrar de alunos que iniciam a escolarização e alunos familiarizados com o contexto escolar? Estas foram algumas das perguntas que puderam ser respondidas com base na análise e na comparação das informações obtidas nos dois extremos desse ciclo.

A opção por realizar a segunda etapa na mesma escola colaborou para que houvesse uma relativa continuidade de contexto, apesar dos três anos de intervalo entre a primeira e a segunda estada em campo.

No presente trabalho, será privilegiada a descrição do contexto encontrado na sala de aula de quarta série. As informações referentes à primeira série comparecerão, especialmente no capítulo IV, como um contraponto, que possibilitará compreender aspectos relativos ao que ocorre nos primeiros quatro anos do ensino fundamental ${ }^{17}$.

\section{II.2.2.1 A escola}

A escola escolhida para a realização da pesquisa tinha classes de primeira a quarta série do ensino fundamental e pré-escola. A escola atendia crianças moradoras de quatro bairros, localizados próximos a ela. Os bairros foram formados por uma ocupação ilegal de terras iniciada em meados da década de 1990 pelo movimento dos Sem-Teto ${ }^{18}$, concentrando em 2000 mais de 2.000 famílias. Desde então, a população da região tem se ampliado.

\footnotetext{
${ }^{17}$ A descrição mais detalhada do modo de utilização dos suportes de registro, especialmente os cadernos, na primeira série do ensino fundamental está em Santos (2002).

18 Organização de pessoas que têm como objetivo ocupar áreas desabitadas visando estabelecer moradia. Diferentes grupos ocuparam a região em questão, formando quatro bairros; alguns grupos, mais organizados, instituíram regras e buscaram recursos para que as pessoas pudessem estabelecerse em melhores condições, fato que atualmente se revela nas diferenças urbanísticas entre os bairros. Desse modo, há bairros que têm predominantemente casas de alvenaria, enquanto em outro são freqüentes os barracos de madeira em condições precárias. Em alguns lugares, é possível o trânsito de veículos pelas ruas, enquanto em outros os imensos buracos dificultam até mesmo a passagem a pé.
} 
Atualmente os bairros contam com energia elétrica e água encanada, infraestrutura obtida pela luta dos movimentos de organização popular e reivindicações aos poderes públicos. Do mesmo modo, a conquista da escola foi conseqüência de muitos pedidos da comunidade, que participou efetivamente da instalação da unidade de ensino.

A escola foi implantada em 1997, em caráter emergencial, contando apenas com dois contêineres como salas de aula. No ano seguinte, foi ampliada, ganhando mais salas e mais vagas. Apesar das melhorias, o espaço ainda era precário, a escola não tinha pátio nem áreas externas cobertas. A única área externa disponível era um campo de futebol improvisado em um terreno vizinho à escola. As refeições eram feitas nas classes, sobre as mesmas carteiras utilizadas para fazer as lições, por não haver outro espaço que pudesse servir para esse fim. As salas de aula eram mal ventiladas, tornando-se insuportavelmente quentes no verão. Aos poucos a infraestrutura foi melhorando: a escola ganhou um pátio coberto e bebedouros, e foram tomadas medidas para aumentar a ventilação das salas.

Em meados de 2000, durante o período de realização da primeira etapa do trabalho de campo, foi concluído o prédio definitivo da escola, que passou a ter amplo espaço de lazer, e demais instalações mais espaçosas, confortáveis e modernas. Assim sendo, o primeiro semestre de pesquisa foi realizado enquanto a escola funcionava no prédio antigo, e os três semestres posteriores ocorreram no novo prédio.

0 prédio atual conta com salas espaçosas e bem iluminadas, biblioteca, amplo espaço de pátio - onde são servidas as refeições e onde as crianças podem brincar em determinados períodos -, quadras de esportes, horta, brinquedoteca e sala de grupo de apoio.

Até 1998, a escola não oferecia educação infantil, e não havia nenhuma outra opção pública, naquela região, destinada à faixa etária inferior a 7 anos. Um número reduzido de alunos freqüentava uma escola comunitária ${ }^{19}$, organizada na residência

19 O número de alunos variou bastante entre início de 1998 e final de 1999, período em que acompanhei as atividades desenvolvidas nessa escola comunitária. Inicialmente havia em torno de 35 alunos, porém, por dificuldades econômicas da escola, em 1999 o número de alunos foi reduzido para cerca de 20. 
de uma das moradoras do bairro, educadora leiga, que oferecia ensino para crianças de 0 a 6 anos. Apenas em 1999 foram criadas na escola municipal duas classes de educação infantil. Na época, o número de vagas oferecidas foi bastante inferior à demanda; isso se tornou evidente quando foram efetuadas as matrículas para 2000: menos da metade dos alunos que cursaram a primeira série naquele ano havia freqüentado escola anteriormente. A partir de então, o número de salas para essa faixa etária foi ampliado significativamente.

Realmente, as mudanças ocorridas foram muito grandes. Até 2000 essa escola era uma das menos procuradas pelos professores no momento de atribuição de aulas, em razão das condições precárias. Depois disso, passou a ser considerada uma das preferidas, tanto pela infra-estrutura que disponibilizava aos professores, quanto pela localização bastante próxima a cidades vizinhas, como Campinas e Sumaré.

\section{II.2.2.2 As relações anteriores com a escola e com a Rede Municipal de Ensino de Hortolândia}

A escolha da escola deveu-se a uma multiplicidade de fatores. Além do contexto apresentado, bastante propício para o estudo de como se dá o aprendizado do trabalho escolar com cadernos, meus contatos anteriores com a escola foram determinantes.

Desenvolvi, nessa a essa escola, diversas atividades. Em 1998 e 1999, por convite da Secretaria Municipal de Educação, Esportes e Lazer, foi realizado trabalho de assessoria psicopedagógica aos professores e alunos. Esse contato inicial possibilitou conhecer aspectos relativos à criação e ao funcionamento da escola, à comunidade que utilizava os serviços desta, à política educacional do município. Além disso, possibilitou o estreitamento da relação tanto com os profissionais da escola quanto com alunos e suas famílias. Ou seja, esse foi um período que abriu as possibilidades para que no ano seguinte, em 2000, fosse desenvolvida a primeira etapa da pesquisa. 
Concomitantemente, em 2000, desenvolvi o projeto "Fabrincar: construção de sonhos e realidades" ${ }^{20}$, que visava implantar brinquedoteca - recurso ainda existente e em funcionamento na escola - bem como capacitar os professores para uma maior inserção da atividade lúdica no dia-a-dia da escola. A fim de resguardar o trabalho de pesquisa com a sala de aula de primeira série da manhã, o projeto foi desenvolvido com os professores do período da tarde.

Nos anos seguintes, desenvolvi algumas atividades direcionadas não apenas aos professores dessa escola, mas também aos de toda a rede municipal de Hortolândia. Em 2002, foi apresentada uma série de palestras para a apresentação dos resultados da pesquisa sobre os cadernos escolares. No mesmo ano, passei a oferecer um curso de capacitação para os professores cujo tema era o desenvolvimento infantil e a atividade lúdica.

O fato de ter desenvolvido trabalhos anteriores tanto na escola, propriamente dita, quanto na Rede de Ensino do município possibilitou o desenvolvimento de uma relação de confiança com algumas pessoas que trabalhavam na rede municipal de ensino, dentre as quais se destacam algumas professoras da escola. 0 convívio anterior me proporcionou um conjunto amplo de informações ao qual não seria possível ter acesso por meio, apenas, da permanência em campo e da observação das salas de aula. Além disso, esse convívio facilitou que a abertura das portas da escola para a realização da pesquisa.

No entanto, os contatos anteriores não interferiram apenas para abrir caminhos. O fato de ser uma pessoa bastante conhecida, especialmente, por algumas professoras da escola, implicou que houvesse uma série de expectativas e conceitos formados a meu respeito. Esse foi um fator que precisou ser considerado no que diz respeito à relação e ao estabelecimento de contato com as pessoas em campo. Por muitas vezes, foi necessário que eu voltasse a lembrar quais eram os objetivos de pesquisa, bem como esclarecer que não estava na escola e na sala de aula para julgar ou avaliar o trabalho dos professores.

${ }^{20}$ Projeto desenvolvido com o apoio do Programa Crer para Ver, iniciativa da Fundação Abrinq e Natura Cosméticos. 


\section{II.2.2.3 A primeira série}

A escola selecionada para o desenvolvimento da pesquisa adotava o caderno apenas a partir da primeira série. Assim sendo, pode-se considerar que, ao acompanhar a primeira série, acompanhou-se a iniciação dos alunos na utilização escolar do caderno.

Para a realização da primeira etapa de pesquisa, inicialmente foi escolhida uma sala de primeira série, das quatro existentes na escola, atendendo a alguns critérios previamente definidos. Pretendeu-se realizar o estudo na sala de aula de uma professora que concordasse com a realização da pesquisa, e que demonstrasse algum interesse nessa proposta. Esse critério foi considerado fundamental, dado que, para a realização de uma pesquisa etnográfica, faz-se necessário o estabelecimento de uma relação de confiança entre o pesquisador e os informantes da pesquisa. Tal confiança foi imprescindível para que eu pudesse permanecer na sala de aula.

Além disso, a relação de confiança permitiu que fossem mantidos constantes diálogos, que favoreceram o acesso a informações fundamentais para a compreensão daquilo que era observado em sala. Outro aspecto considerado ao selecionar a sala de aula foi a escolha de uma professora que não fosse mal avaliada pela equipe técnica - pedagógica e administrativa - da escola; acreditava-se que, ao optar por uma professora bem avaliada, deixaria de ser necessário lidar com uma série de fatores negativos alheios à questão dos cadernos, tais como relações professor-aluno muito negativas ou incompetência profissional.

Assim, foi escolhida a sala de aula de uma professora bastante jovem, com cerca de 20 anos, Ana ${ }^{21}$. Essa professora ingressou na carreira docente em 1999, naquela

\footnotetext{
${ }^{21}$ Todos os nomes presentes neste trabalho são fictícios. 0 nome das professoras brasileiras, particularmente, foram escolhidos por elas próprias, e os demais foram trocados por mim. Essa medida tem como objetivo proteger e resguardar a identidade daqueles que tão gentilmente se dispuseram a ajudar, e que se expuseram, ao permitir o acompanhamento de suas atividades, ao dar valorosas informações, e ao confiar em mim. "Como, de fato, não experimentar um sentimento de inquietação no momento de tornar públicas conversas privadas, confidências recolhidas numa relação de confiança que só se pode estabelecer na relação entre duas pessoas?" (BOURDIEU, 1997, grifos do autor). 0 próprio Bourdieu responde a essa questão da seguinte forma: "protegendo aqueles que em nós confiaram [...] e, acima de tudo, procurar colocá-los ao abrigo dos perigos aos quais nós exporíamos suas palavras, abandonando-os sem proteção, aos desvios de sentido."
} 
mesma escola, quando lecionou na quarta série. Era considerada na escola bastante criativa e a professora que melhor adotava a proposta pedagógica orientada pela Secretaria de Educação do Município, o Construtivismo. Em 2000, teve sua primeira experiência com a primeira série e com a alfabetização.

Desde os primeiros contatos, a professora mostrou-se interessada pela realização da pesquisa e manteve-se sempre disponível para conceder esclarecimentos ou para trocarmos informações. Baseada no que conversávamos, algumas vezes foi possível que Ana pensasse a respeito de sua prática, procurando compreender melhor seus alunos e tomando providências para contornar as dificuldades observadas.

Os alunos que participaram da pesquisa eram provenientes de famílias pobres, residentes nos quatro bairros próximos à escola, como já dito anteriormente. A escola era a única do município que ficava próxima a esses bairros. Todos costumavam ir a pé para a escola, já que a região não contava com transporte público. Dessa forma, alguns percorriam apenas alguns metros, e outros chegavam a caminhar cerca de 20 minutos até chegar à escola. Não havia asfaltamento em nenhuma das ruas daquela região. Assim, por um lado, quando chovia muito, tornava-se quase impossível o acesso à escola a pé. Por outro lado, quando o tempo estava seco, o pó pairava no ar e deixava cheios de terra os móveis, as roupas e todos os demais objetos.

O número de alunos da sala oscilou ao longo do ano. Essa oscilação implicou também mudanças na configuração da turma, dado que, durante a realização da pesquisa, houve uma grande rotatividade de alunos. A lista de chamada que vigorava no primeiro dia de aula continha 32 alunos, dos quais apenas 17 chegaram ao final do ano nessa sala. Algumas crianças saíram, dando lugar a outras, logo no primeiro mês de aulas. Ao final dos primeiros dois meses letivos, a classe tinha 33 alunos, dos quais 3 foram transferidos para outras escolas, e outros 7 foram incluídos, até o final do ano letivo. Essas saídas e entradas foram acontecendo ao longo de todo o ano, e até mesmo no mês de novembro houve a inclusão de um aluno à classe. Em geral, as transferências de alunos ocorriam em virtude das mudanças de residência 
das famílias das crianças, ou por necessidade de mudança de horário em que o aluno freqüentava a escola.

Essa rotatividade trouxe elementos à pesquisa. Em alguns momentos, alunos sobre os quais recaía o foco das observações deixavam a escola sem que fosse possível thes pedir esclarecimentos sobre alguma situação, ou fazer uma cópia de seus cadernos.

Os lugares dos alunos em sala de aula não eram fixos, tanto que a cada observação os alunos estavam posicionados de modo diferente. Havia empenho por parte da professora em garantir que os alunos com problemas de visão se sentassem mais à frente. Em alguns momentos, os alunos que estavam mais atrasados em relação à aquisição dos conteúdos escolares, ou que eram considerados indisciplinados também eram colocados à frente. Exceto nesses casos, eram os próprios alunos que escolhiam os seus lugares.

\section{II.2.2.3.1 Procedimentos}

Os procedimentos utilizados para a realização do estudo na sala de primeira série foram as observações de sala de aula, os encontros informais com professora e alunos, e a análise de cadernos escolares.

\section{II.2.2.3.1.a Observações participantes}

Ao longo do ano letivo, foram realizadas 32 observações em sala de aula, por meio das quais foram acompanhadas as atividades didáticas, e uma reunião entre pais e professora.

Desde os primeiros contatos com a professora, Ana, foram esclarecidos quais seriam os objetivos da pesquisa a ser realizada em sua sala de aula e foi estabelecido o compromisso de haver troca de informações sempre que isso fosse possível e desejado. 
A postura de Ana sempre foi de receptividade, e logo que a proposta de realização da pesquisa foi feita, pela pesquisadora, esta respondeu: "Será um prazer".

A receptividade foi tão grande que possibilitou que eu pudesse participar livremente das atividades da sala de aula sem sequer avisar em que dias e horários estaria presente. Assim, as visitas foram feitas em dias da semana e horários variados. A opção por essa falta de regularidade implicava algumas visitas pouco frutíferas. Em outros momentos, no entanto, contribuiu também para que uma diversidade maior de tipos de atividades pudesse ser acompanhada.

Era perceptível o empenho de Ana em manter o andamento das atividades da sala conforme o planejado, independentemente de minha presença. De modo geral, ela parecia estar bem à vontade apesar de haver uma pessoa estranha na sala. Em nenhum momento, Ana dirigiu-se a mim para conversar. No entanto, sempre que eu a procurava para obter informações ou compartilhar algo que havia sido observado, Ana mostrava-se disponível e procurava ora contribuir para o andamento da pesquisa, ora usufruir a presença de um olhar atento àquilo que ocorria em sua sala de aula. Essa postura foi extremamente importante, pois garantiu-me a liberdade necessária para transitar pela sala e conversar com os alunos, sempre procurando não atrapalhar o andamento das atividades.

As informações compartilhadas com Ana resultavam, com alguma freqüência, em reflexões, por parte desta, que possibilitaram mudanças em práticas, ou em reavaliação de concepções anteriormente adotadas.

Ela disponibilizou, para a pesquisa, materiais pessoais, tais como seu próprio caderno de planejamento de aulas, e suas periódicas avaliações do nível de alfabetização de seus alunos.

O projeto inicial de trabalho previa a realização de entrevistas individuais com cinco alunos. Ao longo do trabalho de campo, porém, foi possível verificar que a utilização da metodologia que permitia acompanhar os eventos, enquanto estes ocorriam, revelou-se bastante rica, pois possibilitou que aspectos da realidade fossem comentados e/ou esclarecidos pelos sujeitos à medida que se desenrolavam, 
além de tornar possível ouvir diferentes versões dos membros envolvidos em cada evento focalizado. Desse modo, avaliou-se que seria mais proveitoso ampliar o número de observações em sala de aula, com a intenção de registrar maior número de informações, aprofundar temas levantados ao longo do primeiro semestre letivo e criar mais oportunidades para conversar com os colaboradores da pesquisa.

Considerando que o objeto deste estudo foi o caderno, produto final de uma série de tarefas e de relações, acompanhar o preenchimento desse material em seu uso cotidiano permitiu que ele fosse visto como um objeto construído ao longo de um processo que inclui muito mais elementos que aqueles que ficam registrados.

\section{II.2.2.3.1.b Encontros com informantes}

Os encontros ocorreram ao longo de todo o ano letivo de 2000 , de modo informal, e consistiram em conversas com os alunos, com a professora da sala de aula onde foi desenvolvida a pesquisa e com a coordenadora pedagógica da escola. O caráter informal deveu-se, em especial, ao fato de nenhuma dessas conversas ter sido marcada com antecedência ou ter obedecido a um roteiro previamente definido de informações que deveriam ser obtidas.

Apesar da informalidade que caracterizou os encontros, destaca-se a presença constante da intencionalidade da pesquisadora nessas conversas utilizadas para obter informações, esclarecer fatos observados, identificar a maneira pela qual os informantes interpretavam situações. Sempre que possível esses encontros também eram utilizados para que fossem apresentadas as reflexões e as hipóteses formuladas a respeito dos eventos ocorridos, a fim de que os informantes pudessem se manifestar. Dessa forma, as compreensões formuladas ao longo da pesquisa podiam ser confrontadas, confirmadas, revistas ou reformuladas de acordo com os pontos de vista dos indivíduos envolvidos na pesquisa.

Até novembro, foi utilizado o procedimento de anotar, ao longo dos encontros, os temas e algumas frases textuais, para que o conteúdo dos diálogos pudesse ser 
retomado e documentado em forma de relato ampliado (RA), posteriormente. Apenas nos dois últimos meses passou a ser utilizado gravador, e, então, houve alguns encontros informais gravados.

As conversas com a professora ocorriam sempre na própria escola, durante o período de aulas, ou no período oposto, quando ela ministrava aulas de reforço.

Após o encerramento da pesquisa de campo, foram realizadas duas visitas à escola, uma em 2001 e outra no início de 2002. Em ambos os momentos, foi possível a troca de algumas informações com a professora.

Os diálogos com os alunos ocorriam ao longo das observações. Tinham como objetivo esclarecer algum aspecto do caderno, ou algum procedimento adotado pela criança. Em outros momentos, havia a intenção de verificar como as crianças avaliavam aquilo que ocorria com elas, ou com outros alunos.

Houve um único encontro com a coordenadora pedagógica, logo no início do trabalho de campo. A iniciativa foi dela, que estava bastante interessada em conhecer quais seriam os objetivos da pesquisa. As informações solicitadas foram dadas e o momento foi aproveitado também para que eu pudesse conhecer algumas das concepções da coordenadora, pessoa que teria papel importante no acompanhamento e na orientação do o trabalho pedagógico das professoras em relação à importância do caderno, e sobre os modos de utilização desse material.

\section{II.2.2.3.1.C Documentos: os cadernos escolares}

Ao longo do trabalho de campo, foram recolhidos alguns cadernos de alunos. Esse procedimento se deu em dois momentos. Primeiramente, no início do segundo semestre, solicitei a quatro alunos que cedessem seus cadernos para que fossem feitas cópias. Nessa ocasião não havia a possibilidade de conseguir os originais, pois ainda estavam sendo utilizados diariamente pelos alunos, mas havia a intenção de garantir que não fossem perdidos os registros que ilustravam cenas que se mostraram, durante as observações, reveladoras. Foram feitas cópias de dois cadernos de alunos 
que demonstravam estar tendo dificuldades em relação ao domínio dos saberes específicos à utilização desse material, e de outros dois alunos que já tinham esse domínio, possuindo cadernos mais completos no que se refere ao conteúdo abordado em sala de aula.

No último dia de aulas, houve a possibilidade de solicitar os cadernos originais aos alunos, dado que não seriam mais utilizados para a realização de atividades diárias. Nessa ocasião havia apenas sete alunos em sala, todos me emprestaram seus cadernos. Foi solicitado também o caderno da professora, que continha todas as atividades propostas ao longo do ano. Ana cedeu prontamente seu caderno.

Os cadernos de alunos recolhidos referiam-se aos trabalhos realizados nos últimos meses escolares. Dois exemplares abrangiam quase a totalidade do segundo semestre, outros dois se referiam ao último mês, e os demais continham atividades apenas dos últimos dias de aulas.

\section{II.2.2.4 A quarta série}

\section{II.2.2.4.1 Os antecedentes da entrada em campo}

O contato inicial com a escola para a realização da segunda etapa da pesquisa ocorreu no começo de fevereiro de 2004, com a ex-diretora da escola. Ela me comunicou que acabara de deixar a direção da escola onde tinha sido realizada a primeira etapa da pesquisa. Estava iniciando o trabalho em outro colégio e recomendou que eu entrasse em contato diretamente com a escola e com Sandra, que tinha acabado de assumir a direção e o trabalho na instituição de ensino.

Por telefone, foi combinado um horário com Sandra para que, pessoalmente, ocorresse uma primeira conversa. Ela tinha vindo de outra unidade escolar e quando The solicitei desenvolver a pesquisa em uma das salas de aula, não demonstrou objeção pessoal alguma. Contudo, ressaltou que tudo dependeria da disponibilidade 
de alguma professora. Nessa época, ela se preocupou com a possibilidade de que nenhuma delas se dispusesse a abrir as portas de sua sala. Combinamos que, em duas semanas, quando efetivamente começassem as aulas, ela entraria em contato para dar uma resposta. No entanto, o período para que tudo fosse estabelecido foi um pouco mais longo, e apenas em março Sandra deu a resposta positiva, dizendo que a professora Silvia já conhecia a pesquisadora, tinha alguma idéia da proposta da pesquisa e estava disposta a contribuir. 0 passo seguinte foi um contato telefônico com a professora, que se mostrou bastante disponível para a realização da pesquisa.

\section{II.2.2.4.2As três professoras e a relação com a pesquisadora}

Inicialmente, a intenção era acompanhar o trabalho de uma única sala de aula e, conseqüentemente, de uma professora. No entanto, de modo inesperado, foi possível acompanhar o trabalho de três docentes.

A utilização da perspectiva etnográfica, que exige o estabelecimento de uma relação de confiança com os informantes, fez com que se tornasse fundamental contar com a concordância, bem como com o interesse das professoras da sala de aula, em participar da pesquisa. Essa confiança e esse interesse tiveram de ser conquistados e reconquistados ao longo do ano letivo.

A primeira professora a participar da pesquisa foi Silvia, que esteve com a classe do início do ano letivo até o mês de junho. Logo após a conversa com a diretora, entrei em contato com ela por telefone e acertamos a primeira visita à sala de aula. Silvia disse me conhecer, pois havia sido minha aluna em curso de capacitação sobre a atividade lúdica dado em 2002 e relatou também ter ouvido uma palestra que dei a respeito dos cadernos escolares. Ou seja, Silvia participou da palestra que tratava de um tema bastante relacionado com o tema do estudo que veio a ser realizado. Dessa forma, a professora teve a oportunidade de me conhecer e de entrar em contato com algumas das proposições do trabalho antes de aceitar e receber o estudo em sua sala. 
Desde o contato inicial, Silvia foi mostrando que gostaria de definir algumas regras para a realização da pesquisa. As portas da sala de aula sempre estariam (e sempre estiveram) abertas, mas queria saber com antecedência em que dia as observações ocorreriam. Uma das justificativas apresentadas por ela para que as visitas ocorressem dessa forma sempre foi a preocupação em manter os alunos informados daquilo que se iria passar.

Silvia disse que, se eu quisesse ir começando meu trabalho, não havia problemas (...) Silvia pediu apenas que eu chegasse meia hora após o início das aulas, para que ela tivesse tempo de receber os alunos e de conversar com eles sobre mim.

(RA - contato telefônico inicial com Silvia)

Quanto ao horário, chegou a ser conquistada uma certa liberdade e flexibilidade. No entanto, por diversas vezes me foi solicitado que sempre avisasse com antecedência sobre a minha presença ou ausência. Em contrapartida, da mesma forma Silvia me tratava, informando previamente suas ausências ou alguma eventualidade que fosse ocorrer. Avisou previamente uma semana em que estaria ausente por motivos de saúde, alertou sobre a possibilidade de deixar a sala bem antes que a saída fosse efetivada ou tivesse uma data definida. Houve, ainda, uma situação na qual Silvia, em vez de dar aulas, foi obrigada a confeccionar um cartaz. Os alunos ficaram assistindo a um filme e apenas três foram chamados por Silvia para auxiliá-la. Nessa situação, ela se mostrou chateada por não ter avisado que não daria aula e justificou o procedimento por ter sido avisada de última hora, no próprio dia em que o evento ocorreu.

Silvia era uma professora jovem, com menos de 30 anos, mas que tinha uma considerável experiência quando, em 2004, assumiu a sua primeira sala de quarta série. Formada em Pedagogia, especializou-se em Educação Especial e chegou a ingressar em um curso de mestrado, que acabou abandonando. Trabalhou por oito anos com educação especial até, em 2002, entrar na Rede Municipal de Ensino de Hortolândia. Em seu primeiro ano no município, trabalhou com o Projeto Brinquedoteca e depois passou a trabalhar com uma segunda série. Em 2004, assumiu a sala na qual foi desenvolvida a pesquisa. Silvia demonstrou e manifestou, durante todo o tempo, 
gostar da sala de aula, tinha um bom relacionamento com os alunos que, assim como ela, ficaram bastante tristes com a sua saída.

A saída de Silvia da sala de aula, assim como a de muitas outras professoras de toda a rede, era algo previsto desde o início do ano. A Secretaria Municipal de Hortolândia intensificou na administração 2001-2004 a realização de projetos pedagógicos de cunho variado ${ }^{22}$ em todas as unidades escolares sob gestão municipal. Tais projetos consistiam em atividades conduzidas por professores da Rede Municipal, aos quais foram oferecidos cursos para que atuassem como especialistas em cada uma das áreas. Nos anos anteriores, tais projetos foram iniciados logo no início das aulas e desenvolvidos ao longo de todo o ano letivo. No entanto, em 2004, isso ocorreu de modo diferente. Não havia professores suficientes para assumir as salas de aula e os projetos. Foi necessária a realização de um concurso para contratação de novos professores. Enquanto os novos profissionais não chegavam, os professores que passariam a conduzir os projetos assumiram salas de aula. Silvia estava nessa condição. Escalada para assumir o projeto Grupos de Apoio, passou a dar aulas para a quarta série onde foi desenvolvida a pesquisa.

A reflexão sobre a função dos registros e sobre as formas mais adequadas para utilizá-los era uma constante para Silvia. Ao longo de minha permanência em campo e especialmente na entrevista, a professora expôs seus questionamentos e dilemas, bem como algumas estratégias encontradas para potencializar o uso dos registros em sala de aula.

No geral, Silvia demonstrava ter compreendido quais eram os interesses da pesquisa, bem como quais eram as estratégias utilizadas para a obtenção de informações. É possível que o fato de ela ter algum conhecimento anterior sobre o tema de pesquisa e sobre o modo pelo qual se dá uma pesquisa acadêmica tenham contribuído para isso.

22 Os 11 projetos desenvolvidos pela Secretaria nas diversas unidades escolares foram: Vida, Cidadania, Hora da Leitura, Trânsito, Comunicação, Adolescer, Brinquedoteca, Teatro, Xadrez, Coordenação de Educação Física, Programa de Grupo de Apoio. 
A professora Malu foi quem assumiu o lugar de Silvia em junho. Dessa forma, o trabalho de pesquisa iniciado com a sala de aula somente poderia ter continuidade caso houvesse a concordância de uma pessoa até então desconhecida. Foi um momento de grande preocupação em razão dessa mudança de docente. Afinal, o estabelecimento de uma relação de confiança tanto com alunos quanto com a professora é fundamental para a condução de um estudo etnográfico em uma sala de aula. Esse tipo de relação é construído ao longo da convivência em campo e leva algum tempo para se fortalecer. Com a primeira professora, havia sido iniciada uma relação que teve de ser rompida e uma nova relação teve de ser construída. A quebra, bem como o investimento para que uma nova relação se constituísse, certamente trouxe algumas perdas ao presente trabalho. No entanto, a possibilidade de acompanhar o processo de mudança de professora possibilitou a aproximação e a compreensão de um evento que faz parte da realidade da escola pública e que foi pouco estudado até o momento: a rotatividade de professores. Além disso, acompanhar diferentes abordagens e os registros resultantes delas trouxe a possibilidade de uma maior diversidade de elementos para a análise das informações. Assim, a substituição da professora proporcionou tanto ganhos quanto perdas ao trabalho de pesquisa.

A despeito de tantas preocupações, Malu foi bastante receptiva. Alguns dias após a entrada da nova professora, estive na escola para apresentar a Malu os objetivos e os procedimentos do estudo que estava sendo realizado em sua sala de aula. Para isso, foi escolhido o dia de Educação Física dos alunos, quando a professora teria aproximadamente uma hora disponível. No entanto, cheguei alguns momentos antes à escola, fui apresentada à nova professora e logo convidada para entrar na sala de aula, antes mesmo de fornecer qualquer informação. Os esclarecimentos iniciais necessários foram dados logo em seguida. Malu não fez perguntas nesse momento, apenas mostrou-se completamente disponível para a continuidade do estudo.

Ao longo da estada na sala de aula, foi possível perceber, em vários momentos, que os objetivos da pesquisa não tinham ficado claros para Malu. Um exemplo disso foi a pergunta que ela me fez, após mais de dois meses de convivência: 
Malu entrega folhinhas mimeografadas com um desenho e o título do texto a ser feito. [...] Em seguida, aproxima-se de mim e vem me perguntar qual é, mesmo, a minha tese. Explico a ela, novamente, sobre minha intenção de compreender a relação entre aquilo que fica registrado e o que acontece na sala de aula. Malu nada diz. Afasta-se novamente.

Quanto ao papel da pesquisadora, também pareceu haver uma certa confusão, como pode ser verificado na situação a seguir, em que a professora discutia, em sala de aula, determinado tema com os alunos:

Malu me convida a participar da conversa, sem se preocupar muito com a minha resposta. "Você não acha, colega?" Chamou-me bastante atenção o vocativo colega, que Malu nunca havia utilizado em relação a mim. [...] Atento para o fato de que esse é o modo pelo qual ela sempre se refere às demais professoras da escola.

E na reunião com os pais, realizada no final do ano:

Malu conta à mãe de Uelinton ${ }^{23}$ quem são as pessoas que estão na sala. [...] Me apresenta de um modo interessante: "A moça que faz estágio."

Tanto no modo de referir-se a mim quanto na maneira de me tratar, Malu demonstrou, com freqüência, me ver como uma professora, no geral, uma professora inexperiente. Outras vezes, como no exemplo citado anteriormente, em que ela se refere ao tema da tese, pareceu identificar que havia realmente uma pesquisadora. Contudo, em nenhum momento pareceu compreender quais eram as intenções subjacentes à pesquisa, ainda que isso the tenha sido explicitado em diversos momentos.

Malu foi aprovada no concurso da prefeitura e, a partir de então, passou a dividir-se entre duas instituições de ensino. De manhã ministrava aulas em uma escola de Campinas e à tarde ia para Hortolândia. Era uma professora experiente,

${ }^{23}$ Destaca-se o fato de a mãe de Uelinton ser cega. 
que dedicou muitos anos à docência. Cursou o magistério em uma cidade do interior paulista e, há alguns anos, veio para a região de Campinas, para iniciar a carreira. Sempre trabalhou para escolas estaduais e, a partir desse concurso, vislumbrou a primeira possibilidade em sua carreira de ser efetivada. Ficou muito contente por poder escolher a escola em que passou a dar aulas, que the era conveniente tanto pela localização quanto pelo fato de ali estar trabalhando uma pessoa de sua família.

A relação de Malu com a sala de aula começou de um modo bastante difícil. Teve que ocupar o lugar de uma professora muito querida pelos alunos e a partir daí estabelecer o seu próprio modo e ritmo de trabalhar.

Malu conta sobre dificuldades para trabalhar com a turma, os alunos
dizem com muita frequiência ['mas a Silvia não fazia assim']. Malu diz que
sempre responde que os dedos da mão são todos de tamanhos diferentes
e que, se todos no mundo fossem iguais, o mundo não teria graça. (RA - 15)

Aos poucos, o estilo de trabalho de Malu foi se estabelecendo e ela foi ganhando, ao seu modo, o carinho dos alunos.

Para a pesquisa, também houve uma mudança sensível. Malu me deixou completamente à vontade para acompanhar as aulas quando quisesse, independentemente de avisar a ela o dia ou horário. Apesar de haver essa flexibilidade por parte da professora, usufruí poucas vezes tal liberdade e continuei mantendo, na maioria das visitas, o dia da semana em que acompanhava a sala de aula. Se, por um lado, havia tal permissão, por outro lado, também a rotina da sala de aula e as eventuais alterações, tais como saídas para o teatro e sessões de vídeo, não me eram comunicadas previamente. Passou a ser freqüente o fato de serem acompanhadas atividades que não incluíam, efetivamente, aquilo que se entende, mais tradicionalmente, por aula. 
Esta é a segunda vez seguida que vou à escola e não acontecem, efetivamente, aulas. Ao que tudo indica, na próxima semana o mesmo acontecerá. [...] Quase todos os alunos saem da sala. Malu me explica, depois, que eles foram pintar as latas para a apresentação (da Semana da Água), pois as que usaram para os ensaios estão muito ruins. [...] Os alunos que ficam pela sala brincam com jogos, escrevem na lousa.

(RA - 26)

Adinâmica das aulas propostas por Malu, freqüentemente pouco centradas na figura do professor, possibilitou que fossem desenvolvidas, em classe, algumas importantes conversas com alunos. As informações obtidas nesses diálogos foram fundamentais para a obtenção de informações a respeito dos registros elaborados pelos alunos, bem como para a seleção daqueles que participariam da etapa de entrevistas.

Houve ainda uma terceira professora acompanhada pela pesquisa a partir do segundo semestre, Valéria, responsável pelo projeto Adolescer.

\section{II.2.2.4.30 projeto Adolescer}

O projeto Adolescer foi um dos vários projetos desenvolvidos na escola a partir do segundo semestre. Alguns dos projetos eram oferecidos no horário de aulas, enquanto outros eram disponibilizados no horário oposto.

O projeto Adolescer, conduzido pela professora Valéria, tinha o objetivo de abordar as mudanças, físicas, emocionais e comportamentais que ocorrem na adolescência. As aulas ocorriam durante o período letivo, apenas para as quartas séries, tendo a duração de uma hora semanal, e logo passaram a ser chamadas pelos alunos de "aulas de sexo". Malu também chegou, algumas vezes, a dizer que eram aulas de educação sexual. Ainda que os conteúdos abordados nas aulas incluíssem temas relacionados à sexualidade, outras temáticas relativas à adolescência também compareceram nas aulas. 0 que realmente, porém, dava identidade ao projeto Adolescer, especialmente para os alunos, era ser o momento em que assuntos relativos à questão sexual eram abordados. 
Casualmente, foi acompanhada a primeira aula do Projeto. Eu estava em sala de aula, realizando as costumeiras observações, quando Valéria chegou para dar início a seu trabalho. Logo na primeira aula, na qual foi apresentado o projeto, a professora pediu aos alunos que separassem algumas folhas de caderno para que fossem realizados registros. Tal pedido me chamou a atenção. Surgiu o interesse por saber como ficariam registrados conteúdos como os propostos pelo Projeto Adolescer, que abordam tanto informações de cunho científico quanto conteúdos subjetivos e que podem estar bastante sujeitos a influências de valores.

Então, a partir de agosto, empenhei-me em acompanhar todas as aulas de Valéria, esforço que foi bem-sucedido na maioria das vezes. Entretanto, em algumas ocasiões, ocorreram imprevistos e mudanças não planejadas de rotina e horários que impossibilitaram que eu estivesse presente em todas as aulas. Realmente, em todos os dias acompanhados, havia conteúdos que deveriam ser registrados; algumas vezes sob a forma de cópia da lousa, outras vezes foram trazidas folhas mimeografadas a ser coladas.

\section{II.2.2.4.4A sala de aula}

Como na etapa anterior tinha sido acompanhada uma sala de primeira série, com alunos que se iniciavam na leitura e escrita, havia o interesse de conhecer um contexto significativamente diferente no que se refere ao domínio dessa forma de comunicação. A opção pela quarta série do ensino fundamental pareceu garantir esse aspecto, ao mesmo tempo que possibilitava que fosse acompanhado um ensino que mantivesse minimamente a mesma estrutura: número de professores, tipo de sala de aula.

Foi escolhida uma das quatro salas de aula de quarta série da escola para essa etapa da pesquisa. Com algumas exceções, os alunos eram capazes de se expressar, com desenvolturas variáveis, por meio da escrita.

Ao longo do ano passaram pela sala de aula 39 alunos. No entanto, a sala nunca chegou a ter, ao mesmo tempo, esse número de alunos. Houve seis alunos que saíram 
antes que o ano chegasse ao fim, e outros quatro que entraram ao longo do ano. Ou seja, a sala de aula teve sempre um pouco mais que 30 alunos matriculados. As faltas eram bastante comuns, em especial no segundo semestre.

A classe tinha uma variabilidade de idade grande, sendo que havia alunos entre 9 e $15 \operatorname{anos}^{24}$. Menos de metade da sala de aula tinha 10 anos, a idade que indicaria um percurso escolar sem repetências ou interrupções. Foram identificados 14 alunos entre 11 e 12 anos. Não foi possível apurar a trajetória escolar de todos os alunos, ainda assim foi possível identificar, entre aqueles que tinham mais de 10 anos, histórias de repetência, em especial na segunda série ${ }^{25}$ e alunos que entraram atrasados na escola.

Outra característica marcante da sala era ser predominantemente masculina. 0 número de meninos foi, durante todo o ano, bem maior que o número de meninas. Como foi dito anteriormente, houve uma certa rotatividade na sala de aula. De qualquer forma, a qualquer altura do ano manteve-se grande desproporcionalidade entre os sexos. $\mathrm{Na}$ maior parte do tempo, dos pouco mais de 30 alunos, apenas 6 eram meninas.

Ao final do ano acompanhado pela pesquisa, quatro alunos foram reprovados, pois não corresponderam, segundo Malu, a professora responsável pela sala no final no ano, aos critérios mínimos de aprovação: ser capaz de ler e escrever e dominar as quatro operações matemáticas. Considerando-se que os alunos aprovados passarão a acompanhar a quinta série no ano seguinte, parece um critério bastante tolerante.

\section{II.2.2.4.5Redefinindo o objeto de pesquisa}

Rockwell (1987) aponta que a análise é o mais longo trabalho da pesquisa etnográfica, pois inicia-se nas primeiras decisões que são tomadas no processo de

\footnotetext{
${ }^{24}$ Foi considerada a idade completada até 31 de dezembro de 2004. Esse cálculo se baseou no critério estabelecido pela Secretaria Municipal de Hortolândia para o recebimento de matrículas. Para o ingresso no Ensino Fundamental, são aceitos alunos que completam 7 anos até 31 de dezembro do ano em que cursarem a primeira série.

${ }^{25}$ A Secretaria Municipal de Hortolândia, que assume o Ensino Fundamental de primeira a quarta série, adota o sistema de ciclos. Assim sendo, há a possibilidade de reprovação apenas ao final da segunda e ao final da quarta série.
} 
observação. $E$, por mais que se planejem previamente os procedimentos a serem adotados pela pesquisa, a autora ressalta que o caminho se faz ao caminhar, ou seja, é necessário adequar as estratégias ao que se apresenta em campo.

Quanto ao objeto de pesquisa, também a etapa de observações é fundamental. Por mais que, anteriormente, se construa de forma cuidadosa o objeto, é em campo e por meio do processo de análise que se torna possível conceituá-lo e defini-lo de modo mais preciso. Assim aconteceu na presente pesquisa. Algumas importantes mudanças ocorreram à medida que avançavam as reflexões a respeito do que era identificado em campo: foram feitos ajustes no que tange a questão e o objeto de pesquisa.

A pergunta inicial era: como os registros escolares elaborados pelos alunos documentam o processo de ensino-aprendizagem, o cotidiano e a cultura escolar? Em busca de responder a essa pergunta, seriam utilizadas apenas as informações obtidas em uma quarta série de escola pública brasileira. Aos poucos, foi considerada a possibilidade de contemplar de maneira mais abrangente as informações que foram sendo obtidas em campo e as oriundas da pesquisa anterior, com a primeira série, fazendo um estudo mais amplo.

Além disso, pude retomar as origens dos meus questionamentos a respeito dos cadernos, que residiam no olhar que a psicologia lançava sobre esses documentos escolares. Todo o processo de pesquisa se originou numa busca por encontrar caminhos que auxiliassem o psicólogo a compreender as produções escolares das crianças, e, dessa forma, percebi que seria importante retornar às questões geradoras, buscando respondê-las.

A primeira etapa da pesquisa, com os alunos que se iniciavam na prática de elaborar registros, revelou que os cadernos não são capazes de documentar o contexto em que são produzidos. A etapa seguinte, com as quartas séries, começava a revelar que a prática de realizar registros se articulava de modo intrincado com os processos que se dão na escola.

A questão de pesquisa passou, então, a ser aquela que orientou a escrita desta tese: como os registros elaborados prioritariamente pelos alunos se inserem no 
contexto escolar e passam a fazer parte do processo de ensino-aprendizagem, do cotidiano e da cultura escolar? A resposta a essa pergunta visa auxiliar na construção de referenciais para a compreensão desses materiais do ponto de vista da psicologia escolar crítica.

Uma pequena adequação foi feita na compreensão do objeto de pesquisa. Inicialmente foi definido como os registros elaborados, predominantemente, pelos alunos. A princípio, antes que o trabalho de campo possibilitasse um bom conhecimento do funcionamento da sala de aula escolhida para a realização da pesquisa, não seria possível dizer quais seriam os suportes e as formas de registro predominantes. Supôsse que seriam encontradas produções em cadernos, fichários, folhas soltas, provas. Estando em campo, foi possível identificar que todos esses suportes eram utilizados. No entanto, os cadernos escolares foram as formas prioritárias de registros, utilizados quase que diariamente, durante todo o ano. Assim, passaram a ser considerados, para efeito de análise das informações obtidas, como o objeto privilegiado. Os demais suportes e seus usos serão descritos à medida que compareçam nas atividades da sala de aula.

\section{II.2.2.4.6 Procedimentos}

\section{II.2.2.4.6.a Observações participantes}

Foram realizadas 32 visitas à escola, com o intuito de conduzir observações na sala de aula de quarta série ${ }^{26}$. Por meio dessas visitas, foram acompanhadas atividades diversas de alunos e professora, e parte de uma reunião entre pais e professora. As visitas à escola ocorreram semanalmente, primeiramente sempre às sextas-feiras e, a partir do segundo semestre, às quintas-feiras. Esses dias foram alterados, em algumas poucas situações, em virtude de necessidades tanto da escola

\footnotetext{
${ }^{26}$ A relação das observações realizadas está no Anexo A.
} 
e das professoras quanto do andamento da pesquisa. A freqüência semanal também chegou a ser interrompida por motivos semelhantes.

Durante a permanência em sala de aula, foram feitas anotações daquilo que ocorria, material este que constituiu o diário de campo. Houve preocupação de observar e anotar a maior quantidade de acontecimentos possível, sem que fosse feita uma pré-seleção daquilo que deveria ou não ser registrado, contudo mantendo em foco o objeto da presente pesquisa: os registros elaborados, predominantemente, pelos alunos. Partia-se do pressuposto que não era possível antecipar, no momento em que ocorria a observação, quais seriam exatamente as informações importantes e quais não seriam. Embora houvesse a intenção de observar de modo amplo o cotidiano da sala de aula, sempre foi necessário fazer opções, baseadas nos questionamentos surgidos ao longo do trabalho, sobre qual deveria ser o foco da observação. Em algumas situações, era dado enfoque àquilo que ocorria em toda a sala de aula, outras vezes a atenção recaía sobre um único aluno ou sobre a professora.

O diário de campo era, posteriormente à estada em campo, acrescido de tudo aquilo que podia ser recordado. Esse segundo documento passou a constituir o relato ampliado (RA) ${ }^{27}$, escrito com o auxílio da simbologia e pontuação proposta por Mercado (1987). Tal relato, mais completo e organizado que o original, tem como objetivo documentar de forma mais detalhada a realidade que se pretende conhecer. Com base nesses documentos cuidadosamente elaborados, torna-se possível a realização das sucessivas análises das informações recolhidas.

Ao longo do ano, variou a liberdade dos alunos em escolher os lugares na classe. No período em que Silvia estava na sala, as carteiras eram dispostas em fileiras e havia lugares fixos, que ela movimentava de acordo com necessidades, especialmente pedagógicas. Assim, havia alguns alunos que sempre se sentavam próximo à sua mesa, para que ela pudesse acompanhar mais facilmente a realização das atividades. Malu introduziu modificações nessa forma de organização dos alunos, que podiam escolher o lugar que preferissem. Não havia lugares previamente determinados, salvo em

\footnotetext{
27 Um exemplo de relato ampliado está no Anexo B.
} 
algumas situações em que ocorreram questões relativas à disciplina. Nesse caso, houve a exigência, por parte da professora, de que alguns alunos se sentassem à frente da sala. A disposição das carteiras foi modificada diversas vezes ao longo do ano. Em algumas aulas, havia fileiras. E em outras, as fileiras eram mantidas, porém, aproximadas, de modo que os alunos se sentavam aos pares. Em outras ainda, foi formada uma espécie de círculo.

No meu caso, a cada dia foi diferente o lugar assumido na sala. A escolha dependia da localização das carteiras disponíveis e dos objetivos, variantes a cada momento, de privilegiar determinada pessoa ou situação. Na maioria das vezes, havia ainda o apelo de alguns alunos para que eu me sentasse próximo a eles. Buscando conjugar todos esses fatores, foi que se deu, a cada visita, a escolha da carteira. De modo geral, havia preferência pelos lugares localizados ao fundo da sala, que permitiam uma visão mais ampla dos acontecimentos no recinto. Quando não havia assentos vazios, era comum os próprios alunos encarregarem-se de liberar ou de ir buscar uma cadeira para mim. No entanto, em especial, no segundo semestre esse fato foi raro, em razão das freqüentes faltas dos alunos.

Havia a intenção e uma constante preocupação de não interferir no andamento das atividades da sala de aula, nem de distrair ou desviar os alunos de seus trabalhos. Foi freqüente surgirem situações nas quais se identificou a pertinência de estabelecer um diálogo com alunos ou com a professora, a fim de esclarecer algo no momento ou obter mais informações sobre alguma coisa que estava ocorrendo. Contudo, a dinâmica da sala de aula nem sempre permitiu ou me deu liberdade para circular entre as carteiras ou conversar com algum aluno. Isso aconteceu, mais freqüentemente, no período em que Silvia assumia a classe. Com a mudança de professora, houve uma sensível ampliação das possibilidades. Era freqüente Malu solicitar aos alunos a realização de atividades, em especial a escrita de textos, e dar-lhes longo tempo para a realização. Esses eram momentos que possibilitavam à pesquisadora um pouco mais de mobilidade pela sala. A limitação da possibilidade de estabelecer conversas 
com alunos e professoras fortaleceu a importância de que, além das observações, fossem realizadas entrevistas.

De qualquer forma, foram as informações oriundas da estada em campo, bem como o estabelecimento de uma relação anterior com os informantes, que trouxeram os elementos necessários à condução da etapa seguinte.

\section{II.2.2.4.6.b Entrevistas}

No projeto inicial de pesquisa, previa-se a realização de cinco entrevistas, uma com a professora da sala de aula observada e quatro com alunos que seriam escolhidos ao longo da realização do trabalho de campo. No entanto, o número de entrevistados se ampliou e acabaram sendo realizadas entrevistas com três professoras e com oito alunos.

\section{i Entrevistas com as professoras}

Aampliação no número de entrevistas com professoras deveu-se às circunstâncias que se apresentaram. A princípio havia a pretensão de acompanhar o trabalho de uma mesma professora, ao longo de todo ano, com sua sala de aula. No entanto, foi necessário acompanhar a substituição da professora inicial por outra que passou a assumir a sala a partir do mês de junho. Por isso, foram acompanhadas duas formas diversas de trabalhar com os alunos, com os conteúdos didáticos, bem como com os registros escolares. A fim de compreender as diferentes peculiaridades e motivações de cada uma dessas profissionais, ambas foram entrevistadas.

Silvia foi entrevistada em duas etapas ${ }^{28}$, nos últimos dias antes de deixar a sala de aula estudada. Ao longo da realização das observações de campo, foram bastante limitadas as possibilidades de conversar com Silvia. A dinâmica de atividades

\footnotetext{
${ }^{28}$ A transcrição da primeira etapa da entrevista com Silvia está no Anexo C.
} 
propostas por ela tornava raros os momentos propícios para conversar a respeito daquilo que era feito. Silvia passava quase a totalidade do tempo ocupada explicando conteúdos, propondo exercícios e acompanhando a sua realização pelos alunos. Assim, as conversas centralizavam-se nos breves momentos em que eu chegava ou saía. Os momentos de recreio das crianças também possibilitaram alguns contatos que não puderam ser prolongados, pois cabia às professoras da escola auxiliar na distribuição da merenda e fazer o acompanhamento dos alunos, em especial, para resolver questões relativas à disciplina. As entrevistas constituíram, dessa forma, momentos em que efetivamente foi possível conversar mais detidamente com Silvia a respeito do seu trabalho e de suas concepções a respeito dos registros.

Quando foi solicitada à professora uma conversa mais cuidadosa sobre o modo como ela utilizava os registros em sua sala de aula, Silvia mostrou-se bastante disponível. Pediu apenas que isso ocorresse nos horários em que a sala de aula estivesse em Educação Física, momento no qual outro professor ficava com os alunos, permitindo que Silvia tivesse 50 minutos livres no meio do período de aulas. Assim, ambas as conversas se deram durante o horário de Educação Física, uma na penúltima e outra na última semana de Silvia com a sala de aula.

A decisão de acompanhar o Projeto Adolescer implicou que também fosse realizada uma breve entrevista com a professora responsável por esse trabalho. Igualmente com Valéria foram raras as situações, ao longo da realização do trabalho de campo, para que ocorresse a comunicação, ou houvesse troca de informações comigo. Suas aulas concentravam-se no período de uma hora semanal, invariavelmente repleto pelas aulas por ela ministradas. Além disso, Valéria era responsável pelo Projeto Adolescer em outras instituições de ensino do município, e somente estava presente na escola onde foi desenvolvida a pesquisa nos horários em que ministrava as aulas nas duas quartas séries. Tais circunstâncias dificultaram, inicialmente, o planejamento da entrevista. A opção que se apresentava, e que me parecia bastante precária, era que fossem utilizados os 10 ou 15 minutos que Valéria tinha de intervalo entre uma sala e outra. 
No entanto, houve uma circunstância inesperada que possibilitou que a entrevista fosse realizada com uma tranqüilidade um pouco maior. No fim de outubro, houve um número muito grande de faltas nas quartas séries. A sala de aula onde foram realizadas as observações tinha 17 alunos presentes e a outra sala de quarta série, apenas 5 . Assim sendo, Valéria optou por juntar as duas classes e dar apenas uma aula, em vez de uma em cada sala de aula. Com isso, Valéria teve pouco mais de uma hora disponível. Aproveitando a situação, propus à professora que realizássemos a entrevista naquele dia, proposta aceita sem qualquer objeção por Valéria. A realização inesperada da entrevista acabou por impossibilitar que esta fosse gravada. Assim sendo, o procedimento utilizado foi fazer anotações durante a entrevista e complementá-las com as informações que puderam ser recuperadas pela memória, logo em seguida. A entrevista versou, especialmente, sobre o modo de utilização dos registros proposto por Valéria, ainda que também tenham feito parte do conteúdo da entrevista algumas informações sobre a história profissional de Valéria, bem como informações gerais sobre o funcionamento do Projeto Adolescer.

A terceira e última entrevista realizada com as professoras foi feita com Malu. Diferentemente do que ocorreu com as outras professoras, as comunicações com Malu foram acontecendo ao longo da estada em campo. Foram freqüentes os momentos em que a própria professora me procurava para fazer comentários sobre o trabalho de seus alunos, sobre situações vividas na escola, sobre sua vida profissional e, até mesmo, sobre a sua vida pessoal. Dessa maneira, a troca de informações não se concentrou unicamente no momento da entrevista. Foi, porém, foi na entrevista que a pesquisadora conseguiu, efetivamente, centrar-se no tema foco da pesquisa. Nos momentos anteriores, houve dificuldades para obter informações mais específicas, pois, no geral, a professora conduzia o diálogo para outras questões.

\section{ii Entrevistas com alunos}

Para qualquer situação de entrevista, é necessário criar condições para que os informantes reconheçam no entrevistador um interlocutor interessado e confiável. 
Tal condição é primordial para a obtenção de informações. No caso da entrevista com crianças, as dificuldades para isso se multiplicam, temos informantes com especificidades que requerem o uso de estratégias diferenciadas que possibilitem que a comunicação ocorra de modo efetivo. Saramago (2001) recomenda:

No contexto dos trabalhos de campo com crianças, torna-se importante
que o investigador se preocupe com criar um espaço de interacção
com os observáveis que de algum modo seja distinto dos padrões
comuns de relacionamento entre adultos e crianças, já que estas
recebem fortes influências das condutas reguladoras socialmente
instituídas. Escapando ao padrão típico de relacionamento adultos-
crianças, o investigador estimula o desenvolvimento de um novo
espaço de interacção, fracamente regulamentado, no qual ambas as
partes têm oportunidade de estabelecer normas de actuação e de
produção de sentido específicas da situação em causa. (p.26)

Para isso, alguns cuidados são fundamentais: a utilização de uma linguagem que possibilite a interação com as crianças e a criação, e constante adequação, das estratégias de maneira que facilitem a expressão das crianças. Tais procedimentos são adotados a fim de que as crianças possam sair da condição de quem ouve, tão recorrente na escola, para passar à condição de alguém que tem algo a dizer.

Desde o planejamento inicial desta pesquisa, pretendia-se realizar entrevistas com alunos da sala de aula observada. Originalmente, previa-se a realização de quatro entrevistas individuais, tendo como objetos desencadeadores das conversas os registros realizados pelo entrevistado ao longo do ano letivo. A intenção dessa etapa do trabalho seria aprofundar e esclarecer, com os alunos, temas identificados ao longo da permanência em campo.

Realmente, no decorrer da realização das observações, foram sendo recolhidos diversos aspectos que mereciam ser abordados de forma incompatível com o andamento das atividades de sala de aula. A necessidade de realização das entrevistas foi reforçada. Entretanto, as interações verificadas em sala de aula sugeriram que fossem realizadas conversas com duplas de alunos. Os dois trechos a seguir ilustram os motivos que conduziram a tal decisão: 
Enquanto o filme passa, converso com Cleber e Alan que estão sentados ao meu lado, um de cada lado. Cleber me vê anotando em meu caderno e pergunta se vou parar de usar meu caderno 'quando parar de vir aqui', ou seja, quando parar de ir à sala de aula deles. Respondo que vou usar bastante, pois anoto as coisas para poder me lembrar depois e poder pensar a respeito. Aproveito a pergunta de Cleber para perguntar sobre os cadernos deles, se eles usam depois que acabam de usar na aula. Cleber me conta uma situação ocorrida no ano anterior em que a professora havia pedido para fazer algo, ele acha que era a raiz quadrada, e aí ele lembrou que a professora da segunda série já tinha ensinado. Aí foi procurar no caderno do ano anterior, encontrou e conseguiu fazer o que a professora tinha pedido. Conta contente que a professora lhe deu Excelente por ele ter conseguido. Pergunto a Alan se ele também usa seu caderno. Ele diz que sim. Eu pergunto "pra quê?" e ele responde "se precisar"; pergunto se já aconteceu alguma situação como a que Cleber contou, em que ele precisou e ele diz que não.

(RA - 20)

Ralph havia me cedido seu caderno já utilizado. O caderno estava no meu colo e Alan o pegou para dar uma olhada. Folheava o caderno do colega, quando o Cleber the deu uma bronca pedindo para ele parar de olhar: "ele (Ralph) vai ter vergonha da letra". Alan folheia mais um pouquinho, mas logo me devolve o caderno de Ralph. Essa afirmação de Cleber me faz pensar em uma série de coisas: o que há em um caderno que dá vergonha, o que dá vontade de mostrar, quando se pode ver o caderno dos outros, quando não se pode... Logo, porém, bate o sinal e todos os alunos se levantam rapidamente. O filme continua passando apesar de os alunos já se encaminharem para fora da sala.

(RA - 20)

O primeiro trecho demonstra, de modo incipiente, o quanto a conversa com um aluno pode trazer temas que podem ser interessantes para conversar com outro, proporcionando maior dinamismo e diversidade de situações. Ou seja, na interação entre dois informantes, é possível que surjam assuntos que não surgiriam, ou que seriam mais escassamente abordados na interação unicamente com a pesquisadora.

O segundo trecho também nos mostra a possibilidade de que aspectos importantes do uso, manuseio e preenchimento dos registros possam ser revelados não só pelas perguntas propostas por quem conduz a entrevista, mas também pela própria interação entre os informantes. Esta tem sido uma das características apontadas por 
pesquisadores que reúnem grupos para a discussão de temas, os chamados grupos focais (MADRIZ, 2000).

A especificidade do presente objeto de pesquisa - os registros -, bem como a idade dos participantes, fez com que se considerasse que a realização de entrevistas em duplas seria profícua, pois era necessário garantir que os entrevistados pudessem realmente interagir em torno dos registros previamente elaborados ao longo do ano. Para isso, as entrevistas em dupla pareceram ser a medida mais eficaz.

Para que pudesse haver um registro satisfatório não somente das expressões verbais dos entrevistados, mas também de suas expressões faciais, movimentos e referências ao material por eles elaborado, optou-se pela filmagem.

As entrevistas foram conduzidas por mim, que estive durante todo o tempo dedicada a interagir com os participantes e a conduzir as conversas de acordo com os interesses da pesquisa. Esse procedimento tornou necessária a atenção total às informações e questões trazidas pelos alunos para potencializar a obtenção de informações propiciada pela situação de entrevista. Dessa forma, não seria pertinente que eu tivesse que também operar a filmadora. A possibilidade de utilização de um tripé foi afastada, pois tal equipamento não permitiria a mobilidade necessária para o registro amplo tanto dos movimentos e das expressões dos informantes quanto das referências feitas aos materiais escolares.

A solução encontrada, para que fosse realizado o registro das entrevistas do modo mais adequado, foi contar com uma auxiliar de pesquisa que ficou responsável pela realização da filmagem.

As razões anteriormente apresentadas indicaram a pertinência da realização de entrevistas em duplas ${ }^{29}$. Foram, então, escolhidas quatro duplas, privilegiando reunir alunos que tivessem demonstrado, ao longo do ano, ter afinidades. Entre os entrevistados, pretendeu-se incluir alunos com características variadas. Assim, participaram alunos que tiveram um bom desempenho acadêmico, bem como alguns considerados maus alunos. Alunos que demonstraram, ao longo do ano, ter um

${ }^{29}$ A transcrição de trecho de uma das entrevistas encontra-se no Anexo D. 
modo de utilização dos registros que chamou a atenção da pesquisadora e alunos que demonstraram especial interesse em falar sobre o tema da pesquisa. Houve, também, a preocupação de incluir tanto meninos como meninas. No entanto, a desproporcionalidade vigente na sala de aula repercutiu na escolha dos informantes e apenas uma menina foi entrevistada.

Os alunos escolhidos foram convidados a participar das entrevistas, que ocorreram pela manhã, ou seja, fora do período de aulas. A direção da escola possibilitou que as entrevistas fossem realizadas em uma das salas vagas da escola. Todos os alunos que foram chamados aceitaram. Alguns demonstraram muita satisfação por participar, enquanto outros demonstraram desconfiança. Como as entrevistas eram combinadas com antecedência de uma semana, algumas medidas foram tomadas a fim de garantir que os alunos não deixassem de comparecer por esquecimento. A primeira medida foi a entrega de avisos por escrito que incluíam o dia e o horário em que seria realizada a atividade e os materiais solicitados, todos os cadernos em uso ou terminados. $\mathrm{Na}$ véspera da entrevista, sempre tomei o cuidado de telefonar para a escola e pedir que os alunos fossem lembrados do combinado. Somente em um dos dias, por problemas na linha telefônica da escola, não foi possível lembrar os alunos, o que não interferiu na presença das crianças, que demonstraram preocupação e empenho em participar dessa etapa da pesquisa.

As entrevistas foram realizadas próximo ao fim do ano, nos meses de novembro e dezembro. Considerou-se que essa seria a época mais oportuna para a intensificação dos contatos com os alunos por algumas razões. Primeiramente, levou-se em conta que era fundamental que, antes de serem estabelecidas as conversas a respeito do objeto de estudo, seria necessário conhecer bem o contexto em que se davam as ações e relações a serem estudadas. Como destacam Sato e Souza (2001):

É importante [...] conhecer o contexto material no qual as interações se dinamizam - a escola ou a fábrica - e, nesse sentido, a observação direta e a observação participante mostram-se como ferramentas importantes, já que as expressões das pessoas são contextualmente referidas. 
Outro aspecto beneficiado pela duradoura permanência em campo, antes da realização desses contatos pessoais mais intensos, é a possibilidade de construir e aprofundar uma relação de confiança com os informantes. Conforme aponta Bourdieu (1997), há uma "violência simbólica" implicada na relação de entrevista, uma violência que, de modo algum, é intencional. Mas ela é inerente à situação de entrevista, dissimétrica nos papéis assumidos por pesquisador e pesquisado, e potencializada quando o entrevistador "ocupa uma posição superior ao pesquisado na hierarquia das diferentes espécies de capital, especialmente o capital cultural." (p. 695). Para minimizar a violência simbólica que pode ser exercida por meio da entrevista, Bourdieu sugere que a seguinte postura do entrevistador:

[...] ela [a postura] associa a disponibilidade total em relação à pessoa interrogada, a submissão à singularidade de sua história particular, que pode conduzir, por uma espécie de mimetismo mais ou menos controlado, a adotar sua [do entrevistado] linguagem e a entrar em seus pontos de vistas, em seus sentimentos, em seus pensamentos, com a construção metódica, forte, do conhecimento das condições objetivas, comuns a toda uma categoria. (p.695)

O autor destaca, ainda, a necessidade de "fazer de tal modo que a interrogação e a própria situação tenham sentido para o pesquisado" (p. 700), e destaca a importância do conhecimento prévio: "somente quando se apóia num conhecimento prévio das realidades que a pesquisa pode fazer surgir as realidades que ela deseja registrar." (p.706)

As entrevistas com os alunos foram divididas em duas sessões, com duração aproximada de 1 hora e meia cada. Na primeira sessão, pretendia-se conversar com os alunos a respeito dos registros por eles realizados. Havia um roteiro de perguntas que se pretendia fazer às crianças. No entanto, esse roteiro acabou funcionando como um conjunto de informações básicas a ser obtidas. Priorizou-se explorar as situações e informações que surgiram na interação com os informantes.

Para a segunda sessão, optou-se por reunir um número maior de alunos. Dessa forma, foram reunidas duas duplas, ou seja, foram formados grupos de quatro alunos. 
Essa mudança no formato se deveu ao formato da atividade solicitada, que se centrou menos na interação entre a pesquisadora e os informantes, e esteve centrada na organização dos alunos em torno de uma atividade. Nessa etapa da pesquisa, solicitouse que os alunos fizessem uma produção a respeito de dois temas: "caderno é..." e “prova é...”. Para isso, foram disponibilizados materiais diversificados, tais como, cartolinas, papéis coloridos, canetas, canetas hidrocor e lápis de cor. Sugeriu-se que os alunos trabalhassem em duplas e que se mantivessem as díades das entrevistas. Os alunos, porém, encontram outras formas de se organizarem.

O objetivo desta etapa era que os alunos, após terem participado da entrevista e, portanto, terem refletido e se manifestado a respeito dos registros, pudessem abordar o mesmo tema de outra forma, com formas de expressão mais próximas das escolares. As duplas foram: Igor e Ralph, Fabiana e Alex, Uelinton e Jordan, Cleber e Leonardo.

Igor e Ralph eram muito amigos. Ambos eram conhecidos na escola como alunos indisciplinados e briguentos, que sempre eram enviados à diretoria. Ralph chamava a atenção pelo tamanho, muito alto. Apesar de ter 12 anos, ele era maior que muitos dos adultos da escola. No início do ano, ainda lia e escrevia mal. No entanto, demonstrava oralmente muita astúcia e o domínio dos conteúdos ministrados. Ralph sempre foi um aluno que se mostrou bastante desconfiado na relação comigo. Igor, também com 12 anos, ainda tinha tamanho de criança. Chamava a atenção pela beleza e pela simpatia. Acompanhava as atividades escolares sem maiores dificuldades, não chegando a ser considerado um bom aluno. Igor demonstrou especial intimidade comigo, pois nós nos conhecíamos desde $1998^{30}$. Durante as observações, procuravame para contar sobre a família, confidenciar paixões e desafetos.

A segunda dupla foi formada por Alex e Fabiana. Os alunos eram amigos e tinham várias situações em comum ao longo do ano, mas não chegavam a constituir uma dupla. Fabiana chegou à escola após o início do ano, em maio, vinda do litoral. Muito falante e simpática, logo se entrosou com os colegas de sala. Era uma menina

\footnotetext{
30 Igor estudava, em 1998, em uma pré-escola comunitária da região à qual prestei assessoria. Desde então, sempre manteve contato com a pesquisadora quando a encontrava seja na pré-escola ou na própria escola.
} 
com uma história escolar de sucessos. Sempre foi aprovada e tirou boas notas. Alex era um aluno que não preocupava a professora por seu desempenho acadêmico. Vez ou outra, envolvia-se em brigas com colegas da sala. Sua família era evangélica, e conteúdos relativos à religião chegaram a compor o conteúdo de seus registros.

Das duplas formadas, a de Uelinton e Jordan era a que menos incluía amizade entre os participantes. Os dois alunos tinham alguma simpatia um pelo outro, mas não chegavam a compartilhar situações. A junção desses dois alunos deveu-se mais ao interesse da pesquisadora em entrevistá-los.

Uelinton era um aluno discreto e bem comportado. Miúdo, esperto e dedicado, saía-se muito bem na escola, era considerado um dos melhores alunos da sala. Uma informação descoberta pela pesquisadora quase no final do ano chamou ainda mais a atenção da pesquisadora sobre ele: os pais dele eram cegos. Jordan, por sua vez, era um dos alunos com maiores dificuldades nessa classe. Ao final do ano, ainda expressava-se de modo incompreensível por escrito, fato que corroborou em sua repetência ao final do ano. Era conhecido na escola por ser briguento e indisciplinado. Jordan teve uma participação bastante restrita nas entrevistas, chegando atrasado, indo embora mais cedo e faltando à ultima. Chegou a me dizer que não gostava de falar de sua vida.

A última dupla a ser entrevistada, Cleber e Leonardo, foi na realidade a primeira a ser convidada. No meio do ano, Cleber havia me cedido um dos seus cadernos finalizados. Desde esse momento, havia sido aventada com o aluno a possibilidade de realizar-se uma conversa sobre o material. Nesse momento da pesquisa, os critérios para a escolha dos entrevistados ainda não estavam claramente definidos e por isso perguntei a Cleber sobre qual seria o colega que ele gostaria que estivesse com ele nessa conversa. Foi Cleber quem escolheu Leonardo, um aluno a quem eu havia dedicado pouca atenção ao longo do ano.

Cleber era um bom aluno. Apesar da repetência na segunda série, teve uma história escolar sem maiores problemas. Com forte característica de liderança, organizava os colegas e a própria sala de aula. Leonardo era um aluno discreto, 
cumpria as atividades propostas pela professora e, às vezes, cometia alguns atos considerados indisciplinados. Não era um dos alunos com quem eu tinha inicialmente planejado conversar mais demoradamente e sua participação na entrevista, surpreendentemente produtiva, ocorreu a pedido de Cleber.

\section{iii $\underline{\text { A auxiliar de pesquisa }}$}

A solução encontrada para a realização adequada do registro das entrevistas foi contar com uma auxiliar de pesquisa, Natali Tiburcio, uma estudante de graduação do segundo ano do Curso de Psicologia da Pontifícia Universidade Católica de Campinas, com especial interesse em psicologia escolar.

Durante toda a pesquisa, valorizou-se o estabelecimento de uma relação de confiança com os informantes. Considerou-se que esse modo de estabelecimento do contato seria fundamental para a obtenção de informações (BOURDIEU, 1997). Por isso, proporcionou-se que Natali convivesse um pouco com as crianças que seriam entrevistadas. Supôs-se que o fato de ela ter um contato com os alunos anteriormente à realização das entrevistas seria importante para que houvesse condições de que estivesse presente e filmando o momento em que, mais intensamente, ocorreria a obtenção de informações.

Foi realizada uma preparação para a entrada em campo da estudante. Encarregueime de orientá-la sobre o objeto e a metodologia da pesquisa desenvolvida. Para isso foram realizadas algumas reuniões entre nós, além da leitura e discussão de textos auxiliares.

Então, a auxiliar de pesquisa passou a acompanhar, a partir do início de novembro, as visitas à escola e as observações em sala de aula. Para a primeira visita da auxiliar, planejou-se a chegada das pesquisadoras durante o recreio. Assim, os alunos teriam algum tempo menos ocupado pelas atividades formais para começar a tomar contato com Natali, cuja chegada causou muita curiosidade nas crianças. Logo começaram as perguntas, que continuaram quando houve a entrada em sala de aula: 
Assim que entramos na sala mais algum aluno pergunta se somos irmãs. Acho até uma boa hora para dizer quem é Natali, afinal tem um grande número de alunos na sala. Explico que ela vai me ajudar a partir de agora na pesquisa e que, por isso, passará a vir sempre comigo.

(RA 28)

E logo foi possível perceber que os alunos a receberam muito bem:

Quando estamos quase na porta da sala de aula, Cleber diz para Natali: [“você está em casa."].

Com a sua entrada em campo, a auxiliar passou a agir tal como eu costumava proceder. Sentava-se em algum lugar disponível da sala de aula e fazia anotações que, posteriormente, transformava em relatos ampliados. Os relatos elaborados por Natali passaram a constituir material complementar de registro de campo.

Durante as entrevistas, cabia à auxiliar operar a filmadora, buscando registrar da melhor forma possível tanto os entrevistados e suas expressões quanto os registros utilizados como referência para o diálogo. Deixei Natali à vontade para fazer perguntas, quando julgasse conveniente, fato que ocorreu poucas vezes.

\section{iv Análise dos registros}

Conforme foi apontado anteriormente, um dos principais objetivos da presente pesquisa é compreender quais são os meandros institucionais e relacionais em meio aos quais a prática de realizar registros se estabelece na escola. Por isso, cadernos, provas e folhas soltas preenchidos ao longo do ano, no dia-a-dia da sala de aula constituem importante material de consulta para este trabalho. Optou-se por estudálos em sua utilização, por meio do acompanhamento da execução das atividades escolares, e de conversas com alunos e profissionais da escola no decorrer das ações que davam forma aos registros. A análise das produções escritas pôde ser um recurso útil para a tarefa de compreender como os registros se inserem e passam a fazer 
parte do que ocorre na escola, especialmente por essa análise ter sido utilizada como estratégia complementar às demais estratégias utilizadas. Assim, buscou-se realizar a análise dos registros à luz daquilo que foi observado em campo e como forma de complementar as informações previamente obtidas.

Não houve a intenção de esmiuçar o conteúdo dos registros. Ainda assim, compreende-se que a análise desses materiais possa ser importante para compor uma resposta aos questionamentos apresentados por esta pesquisa. Por isso, houve grande empenho para recolher o maior número possível de registros. Esta iniciativa teve início ao final do primeiro semestre, quando alguns alunos começaram a ter seus cadernos, aproximando-se do final.

Era freqüente que eu thes pedisse que me dessem ou emprestassem os cadernos utilizados. Alguns alunos me cederam definitivamente seus materiais. Outros me emprestaram temporariamente, para que fosse feita cópia. Em alguns momentos, a própria professora Malu forneceu alguns materiais que foram copiados. 0 momento em que se obtiveram mais cópias foi ao final do ano, mais especificamente logo após as entrevistas. Assim que eram encerradas as conversas com os alunos, eu thes solicitava todos os materiais trazidos. As cópias eram rapidamente providenciadas, a fim de que eles pudessem poucas horas depois participar das aulas com tudo aquilo de que necessitavam.

Os documentos obtidos foram analisados com o objetivo de auxiliar na construção de categorias. As categorias sociais apreendidas com base no trabalho de campo e nas entrevistas, bem como o referencial teórico, serão a base para construí-las. Conforme apontam Ludke e André (1986), a construção de categorias não é uma tarefa com regras fixas para a sua condução. As autoras, porém, sugerem estratégias que auxiliam a olhar para os documentos de um modo criterioso, que se pretende adotar para a análise dos documentos por ora em questão. Ressaltam a importância do exame cuidadoso do material em busca de aspectos recorrentes, sem, contudo, desconsiderar os aspectos discrepantes e isolados, que podem ser fundamentais para a compreensão da questão.

Chartier (2005) recomenda cuidados especiais para a realização da análise de cadernos escolares, que são objetos com os quais, invariavelmente, os pesquisadores 
têm familiaridade. Destaca a necessidade de desprendimento dos saberes oriundos da experiência pessoal, pois, ainda que sejam uma referência cultural facilitadora, podem resultar em formas de olhar que impedem a aproximação e o conhecimento desses objetos de estudo em referência às normas escolares, sociais e culturais em que foram produzidos.

\title{
II.2.3 A ETAPA FRANCESA DE OBTENÇÃO DE INFORMAÇÕES
}

\begin{abstract}
"Quem não observou uma outra cultura, reconhecendo-a como legítima, não sabe que sua cultura é uma cultura. Vive sua cultura na evidência, como um modo de vida natural, o único possível, sem essa distância que lhe permite tomar consciência de que é uma cultura."
\end{abstract}

(CHARLOT, 2001)

Ao observar uma outra cultura, abre-se uma possibilidade de reflexão sobre a cultura em que se vive. É por meio partir desta que se conhece aquela. Ainda que haja a intenção de conhecer uma cultura sem adotar um olhar comparativo, as diferenças chamam a atenção, assim como surpreendem algumas semelhanças. Ao conhecer algo diverso, aquilo que sempre nos pareceu extremo pode ser relativizado. Aspectos que sempre passaram desapercebidos e vistos como naturais passam a poder ser questionados.

Foi assim que me aproximei dos cadernos franceses e que apreendi um pouco do seu modo de utilização nas salas de aula francesas. Durante dois meses e meio foram feitas observações em oito salas de aula de três diferentes escolas públicas. Duas dessas escolas localizavam-se em bairros periféricos de Paris, e outra na cidade de Mons.

Foram realizadas 16 observações, com durações entre 1 hora e meia e 3 horas, em salas de aula de alunos de 6 a 10 anos, ou seja, foi dada preferência ao acompanhamento de salas de aula de alunos com faixa etária próxima à dos que tinham sido acompanhados no Brasil. 0 quadro a seguir mostra a equivalência etária dos níveis de ensino no Brasil e na França: 


\section{BRASIL}

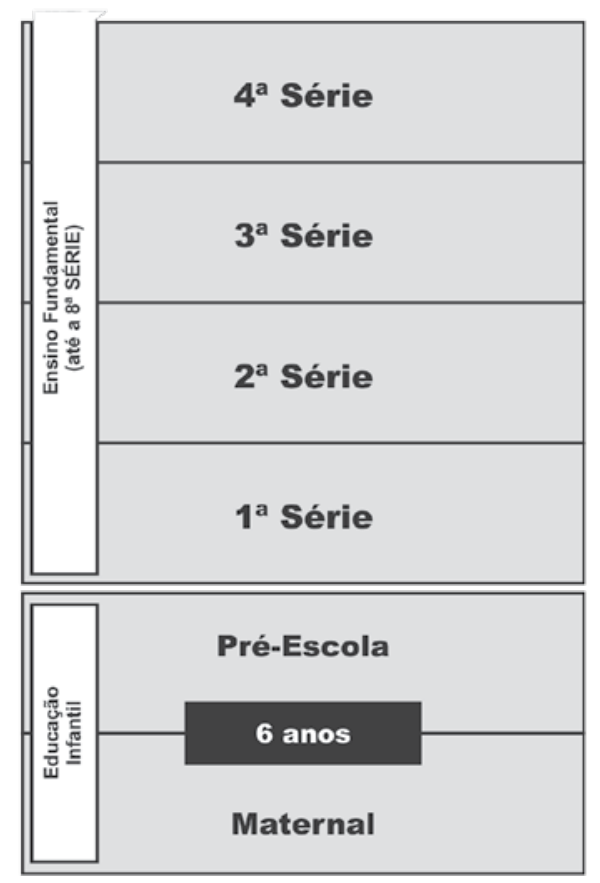

FRANÇA

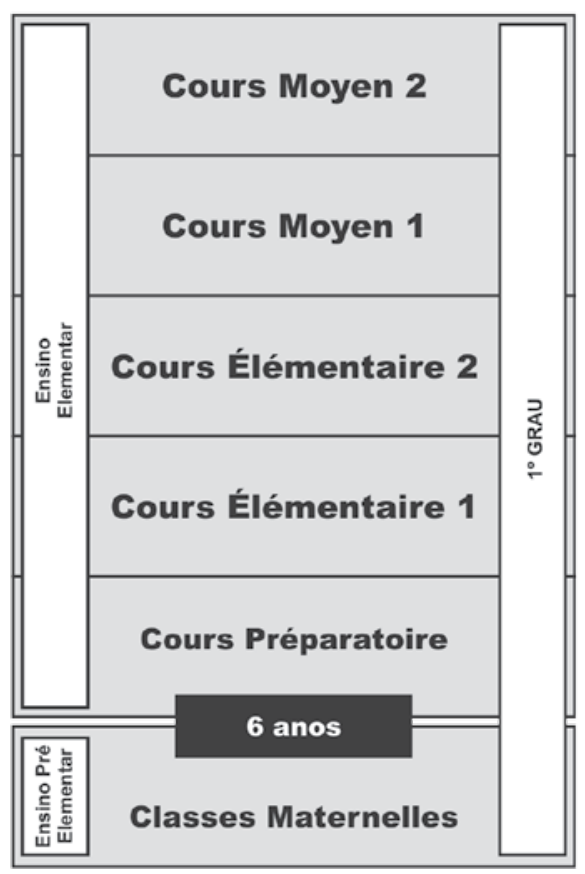

Figura 2. Quadro Comparativo dos Sistemas de Ensino Brasil-França ${ }^{31}$

As observações foram distribuídas da seguinte maneira:

Tabela 1. Número de observações em salas de aula de escolas francesas

\begin{tabular}{clc}
\hline Localização da Escola & \multicolumn{1}{c}{ Nível } & Número de Observações \\
\hline Paris - Escola 1 & Cours Préparatoire (CP) & 4 \\
& Cours Élémentaire 1 (CE1) & 1 \\
& Cours Moyen 1 (CM1) & 2 \\
\multirow{2}{*}{ Paris - Escola 2 } & Cours Moyen 1 & 5 \\
\multirow{2}{*}{ Mons } & Cours Moyen 2 (CM2) & 1 \\
& Cours Préparatoire & 1 \\
& Cours Moyen 1 & 1 \\
& Cours Moyen 2 & 1 \\
\hline
\end{tabular}

31 Adaptação de quadro comparativo apresentado em Bourdieu (1997). 
Durante toda a realização das observações de campo na França, busquei manter os preceitos da etnografia que eram possíveis diante das condições concretas em que eu estava. Assim sendo, houve a intenção de compreender os significados que as ações e os objetos adquiriam na cultura francesa e, sobretudo, para aqueles com quem tive contato. Foram feitos registros durante o tempo dedicado à observação, que posteriormente foram transformados em relatos ampliados ${ }^{32}$.

Suspender os julgamentos foi uma tarefa ainda mais custosa ao estar numa cultura diferente da que eu conhecia até então. Surpreenderam-me as regras vigentes na escola, as formas de punição impostas aos alunos, bem como as exigências feitas. As escolas que conheci em Paris me pareceram bastante rígidas. Minha sensação, exposta em alguns momentos a professores franceses, causou-thes estranheza. Não se reconheciam na rigidez que eu percebia. Perguntavam-me como era no Brasil e, quando eu comentava que eram comuns e aceitáveis as conversas pouco ruidosas, assim como o trânsito dos alunos em sala de aula, não conseguiam compreender como era possível um professor trabalhar sob tal desordem.

Entretanto, a riqueza material de que dispunham chegou a me impressionar e fascinar. Pequenas bibliotecas, máquinas fotográficas digitais, aparelhos de som e até filmadoras faziam parte dos recursos didáticos da sala de aula. 0 que me parecia mais do que suficiente não era percebido da mesma maneira pelos profissionais da escola, que às vezes reclamavam da falta de recursos e se organizavam para reivindicar verbas ao poder público.

Os exemplos que acabei de apresentar ilustram como, apesar do impacto que o diferente me causou, procurei todo o tempo buscar as significações locais do que observei. Tal tarefa implicou um esforço bastante grande e, certamente, nem sempre alcançado. A escassez de tempo, bem como os entraves referentes à língua, não permitiram maior aprofundamento na compreensão de como os cadernos se inserem no cotidiano escolar francês. A possibilidade do estabelecimento de relações de confiança também ficou comprometida pelas dificuldades de comunicação e, sobretudo, pela curta duração do

32 Os relatos ampliados redigidos com base nas observações realizadas em escolas francesas serão identificados pela sigla RAF, devidamente numerada 
contato. Na impossibilidade de desenvolver um estudo etnográfico, dirigi um olhar inspirado pela etnografia às escolas francesas e ao modo pelo qual se davam os registros.

De qualquer forma, nunca houve a intenção de conduzir um extenso estudo comparativo. Mais do que descrever minuciosamente as características francesas, havia a intenção de buscar elementos culturalmente diversos que permitissem fazer reflexões a respeito de aspectos brasileiros. Ou seja, a apresentação de informações referentes às escolas francesas se dará com o intuito de ampliar o olhar sobre a realidade que tive a oportunidade de conhecer no Brasil.

\section{II.2.3.1 Observações em salas de aulas francesas}

Os contatos iniciais com as escolas foram intermediados por Anne-Marie Chartier, pesquisadora do Service d'Histoire de l'Éducation do Institute National de Recherche Pédagogique (INRP) que me orientou durante todo o período no exterior.

Nas escolas houve, de modo geral, abertura para que fossem feitas as observações em sala de aula. Nenhum professor se opôs a me receber. Alguns foram especialmente receptivos e se demonstraram bastante disponíveis para fornecer informações, materiais dos alunos e esclarecer minhas dúvidas. No geral, percebi que tinham orgulho de poder mostrar seu trabalho a uma pesquisadora estrangeira.

Os alunos manifestaram de maneira bem mais discreta do que no Brasil sua curiosidade em relação ao fato de haver uma pesquisadora na sala de aula. Poucos olhares, raras perguntas ou iniciativas de conversa.

Apenas uma professora me deu a oportunidade de me apresentar aos alunos da sala de aula. À frente da classe, disse que era uma pesquisadora brasileira interessada em saber como as crianças francesas aprendiam. A professora perguntou aos alunos se sabiam localizar o meu país no mapa. Uma aluna levantou a mão e, depois da aprovação da professora, dirigiu-se ao mapa afixado na parede. Indicou corretamente a localização do Brasil. Alguns alunos ficaram um pouco agitados, querendo fazer perguntas a respeito 
do meu país de origem. Rapidamente a professora interrompeu a iniciativa das crianças, dizendo que quem quisesse conversar comigo utilizasse o tempo do recreio.

Em uma das salas de aula, a professora se encarregou de comunicar que eu acompanharia uma parte do período de aulas. Nas demais, nada foi dito aos alunos.

Sempre adotei o procedimento de sentar-me ao fundo da sala de aula. Algumas vezes foi possível dispor de uma mesa semelhante às dos alunos, outras apenas uma cadeira foi colocada para que eu pudesse me sentar. Foram raras as vezes em que me senti à vontade para circular pela sala de aula ou para estabelecer conversas com os alunos em classe.

Todas as escolas onde estive se caracterizavam por fazer parte de Zones d'Éducation Prioritaire (ZEP) ${ }^{33}$. As salas de aula visitadas caracterizavam-se por ter entre 20 e 25 alunos, dos quais boa parte tinha origem ou ascendência estrangeira. Franceses, árabes, africanos, europeus orientais e até chineses estudavam juntos. As professoras relatavam ter classes quase que totalmente bilíngües, com muitos alunos tendo o francês como segunda língua. Esse fato trazia peculiaridades e dificuldades.

$\mathrm{Na}$ primeira escola, foram visitadas duas salas de aula, uma de CP e outra de CM1. Os contatos iniciais com a escola e com as professoras foram mediados por Anne-Marie Chartier que desenvolvia na escola trabalhos de assessoria pedagógica.

A professora da classe de CP, Géraldine, era considerada uma professora experiente e bastante competente; enquanto a sala de CM1 contava com uma professora jovem, Cécilie, com pouca experiência, porém com bastante dedicação.

Na segunda escola, a entrada para a realização da pesquisa deu-se por um pedido feito às instâncias superiores de ensino, que indicaram algumas escolas nas quais a pesquisa poderia ser realizada. Em reunião com a presença de todas as professoras e da diretora da escola, foram apresentados os objetivos da realização do estudo. Algumas professoras manifestaram interesse e disponibilidade para que suas salas de aula recebessem a minha visita. Assim, foram realizadas observações em três salas

\footnotetext{
33 As Zones d'Éducation Prioritaire vêm sendo adotadas na França desde 1981. Trata-se de uma estratégia utilizada para enfrentar o fracasso escolar nas regiões economicamente mais desfavorecidas, praticando uma política denominada de discriminação positiva. As escolas que se encontram nas ZEPs têm menor número de alunos por classe, recebem recursos financeiros e postos de trabalho adicionais.
} 
de aulas, duas de CM1 e uma de CM2. As duas professoras de CM 1, Gisele e Claire, trabalhavam juntas com ambas as salas. Cada um era responsável por um conjunto de disciplinas. Séraphine era a responsável pela sala de CM2.

As duas escolas localizavam-se em Paris e assemelhavam-se bastante entre si em termos pedagógicos e de organização. E foi onde, efetivamente, foram realizadas as observações mais sistemáticas, que se repetiram ao longo das semanas que passei no exterior. No capítulo $\mathrm{V}$, quando serão apresentadas as análises referentes à etapa francesa da pesquisa, comparecerão descrições relativas ao trabalho dessas seis professoras acompanhadas nas ZEPs de Paris.

A escola de Mons, por sua vez, diferiu de tudo o que eu tive a oportunidade de conhecer até então. Era uma das raras escolas francesas a adotar a pedagogia Freinet. Assim sendo, organizava-se de modo completamente peculiar, altamente baseado no desenvolvimento da autonomia dos estudantes. Em contato e intercâmbio constante com a universidade, era muito bem avaliada pelo meio acadêmico. Localizava-se em um bairro pobre da cidade onde, segundo os professores da escola, a taxa de desemprego estava em torno dos $50 \%$. Contava com popularidade entre as famílias da região, que disputavam as vagas na instituição educacional. Distinguia-se das demais escolas francesas que conheci por ter uma boa quantidade de homens na docência. Das três salas de aula visitadas, apenas uma contava com uma professora na regência. Infelizmente, não foi possível passar mais que um dia na escola. E, dessa forma, não foi possível aprofundar o conhecimento a respeito do que foi observado. A novidade, aliada à impossibilidade de uma imersão, me fez optar por não incluí-la nas análises que apresentarei. Apesar de tomar tal cuidado, faço a opção de citar a existência de uma escola francesa que funciona sob um padrão diverso do que apresentarei.

\section{II.2.3.2 Encontros informais com professoras}

Além das observações, foi possível, em alguns momentos, estabelecer diálogos com algumas professoras. Tais conversas, ocorridas um pouco antes das aulas ou depois 
delas, bem como nos momentos em que os alunos estavam com outros professores, possibilitaram esclarecer aspectos que eu não tinha compreendido bem enquanto observava e recolher informações sobre o modo pelo qual se faziam os registros. Algumas professoras também aproveitaram o momento para fazer algumas perguntas a respeito de como era educação no Brasil.

\section{II.2.3.3 Análise dos registros}

Outro procedimento adotado durante a permanência nas escolas foi o de recolher documentos. Dada a dificuldade e morosidade no procedimento de fazer cópias, optei por utilizar uma máquina fotográfica digital para fazer o registro fotográfico de páginas de alguns cadernos que me foram disponibilizados. Antes de fotografar, sempre solicitei permissão às professoras. Todas elas se ocuparam de me fornecer um conjunto de cadernos para que eu pudesse fotografar. 0 material selecionado sempre primava por estar absolutamente em conformidade com as regras escolares. Ou seja, apenas os cadernos mais adequados, sob a avaliação docente, me foram disponibilizados. Raríssimos foram os momentos em que pude fotografar cadernos escolhidos por mim.

Os documentos obtidos serão analisados como descrevi anteriormente quando abordava as informações obtidas no Brasil. 


\section{OS REGISTROS EM UMA SALA DE QUARTA SÉRIE}

Professora: "Agora vocês podem copiar no caderno. Podem pôr a data de hoje."

Professora: "As contas vocês podem fazer no caderno, embaixo da folhinha."

Há uma grande variedade de cadernos na sala. Alguns tipo universitário, outros pequenos. Há os que têm muitas folhas e possibilitam a subdivisão em disciplinas e aqueles que são mais finos. Alguns encapados com etiquetas, indicando nome e série colada à capa, outros com capas comerciais coloridas. Um único aluno usa fichário.

Os alunos não entendem muito bem a atividade proposta, não sabem o que responder. Silvia ajuda: "O que vocês entendem por situação difícil?"

Gianny responde : "Quando um poste cai em cima da casa." Talita, depois de muito pensar, diz: "Fazer uma prova."

Após a leitura do texto, Silvia recomenda como eles devem copiar: "2 ou 3 dedos da margem, no começo do parágrafo." Lembra que devem utilizar letra maiúscula no começo das frases e recomenda que devem prestar atenção no que copiam para não copiar tudo errado.

As cenas que acabam de ser apresentadas ilustram o dia-a-dia de uma sala de aula de quarta série do ensino fundamental da rede pública de um município do interior de São Paulo. Todas foram recolhidas em uma mesma sala de aula ao longo do ano letivo e citam diferentes suportes de registro utilizados na sala de aula em questão: os cadernos, as "folhinhas" e as provas. São cenas que possivelmente parecerão bastante familiares àqueles que tenham passado pela escola e, conseqüentemente, pela experiência escolar de utilizar suportes de escrita: os cabeçalhos, as cópias nos cadernos e suas regras, a resolução de contas, os modos de encapar e identificar os cadernos e as provas difíceis. 
A utilização de suportes de escrita, tais como cadernos, folhas soltas, provas e pequenas lousas, é uma prática bastante arraigada na cultura escolar ${ }^{1}$. Em certos contextos, alguns destes suportes ganham evidência e outros são pouco ou nada utilizados.

Apesar de as cenas citadas estarem circunscritas no tempo, em um determinado espaço e em um contexto sociohistórico específico, têm muito em comum com aquilo que ocorre em outras escolas.

Também é bastante possível que haja alguns aspectos ou detalhes que pareçam estranhos ao leitor. Afinal, em cada contexto escolar, alguns procedimentos ganham características locais, dependendo do professor e de seus alunos, bem como de exigências e hábitos institucionais e locais. Se algumas escolas adotam cadernos padronizados, outras permitem que os alunos e suas famílias façam as escolhas. A distância da margem, as cores utilizadas, o número de linhas que devem ser deixadas em branco entre diferentes atividades são procedimentos que podem variar. As formas de avaliação podem ou não incluir as provas. E estas, por sua vez, podem parecer mais ou menos ameaçadoras aos alunos.

As sensações ora de familiaridade, ora de estranhamento, que os relatos recolhidos podem proporcionar, são diretamente ligadas ao modo pelo qual se constitui o uso escolar dos suportes de registro. É em meio a uma intersecção de culturas que se constitui a prática de utilizá-los e preenchê-los.

A discussão a respeito daquilo que faz com que os registros feitos em contextos diferentes se assemelhem e se diferenciem entre si será retomada, com mais elementos, nos capítulos seguintes. Vejamos agora como tomaram forma os suportes de registro de uma sala de aula de quarta série de uma escola pública do interior do estado de São Paulo, em 2004.

\footnotetext{
${ }^{1} \mathrm{O}$ conceito de cultura escolar tem sido abordado por diversos autores. Considerou-se o conceito apresentado por Julia (2001) pertinente para auxiliar na compreensão de como os cadernos se inserem no contexto escolar. $O$ autor alega que a cultura escolar não pode ser compreendida sem que sejam consideradas as "relações conflituosas ou pacíficas que ela mantém, a cada período de sua história, com o conjunto das culturas que the são contemporâneas" e apresenta a seguinte definição: "conjunto de normas que definem conhecimentos a ensinar e condutas a inculcar, e um conjunto de práticas que permitem a transmissão desses conhecimentos e a incorporação desses conhecimentos".
} 


\section{III.1 ONDE SE REGISTRA?}

Inicialmente, conforme foi exposto nos objetivos do presente trabalho, havia a intenção de conhecer como os registros, elaborados prioritariamente pelos alunos, se inseriam naquilo que ocorria na escola. Ao se definirem os registros, de modo amplo, como objeto de estudo, havia a intenção de ampliar o olhar, de atentar para além dos suportes de registro mais corriqueiros nas escolas: os cadernos escolares. Assim, também seriam objetos de atenção provas, folhas soltas, cadernos de atividades com exercícios previamente impressos ou outros suportes que viessem a se apresentar.

Ao não restringir o estudo aos cadernos, pretendia-se conhecer as diferenças e semelhanças entre os diversos suportes de trabalho discente. Diferentes suportes são utilizados para diferentes atividades? Como se caracterizam as atividades? Que sentidos adquirem para os alunos os trabalhos desenvolvidos em cada um desses suportes?

O desenvolvimento do trabalho de campo possibilitou que fosse acompanhado o trabalho de três diferentes professoras com a mesma sala de aula. A maneira pela qual cada uma delas propôs a utilização dos suportes de registro tem muito de comum e algumas diferenças. No presente capítulo, em que se pretende realizar a descrição de como se dava a utilização desses materiais na sala de aula de quarta série de uma escola pública do interior do estado de São Paulo, haverá momentos nos quais serão ressaltadas peculiaridades de cada uma das docentes e características que os diferentes modos de proceder puderam imprimir àquilo que ocorria na sala de aula. Mais adiante, quando salas de aula francesas também serão tomadas como objeto, será feita a opção de privilegiar abordar em conjunto o trabalho desenvolvido pelas três professoras. 


\section{III.1.1 OS CADERNOS ESCOLARES}

- Belo como a coisa nova na prateleira até então vazia.

- Como qualquer coisa nova inaugurando o seu dia.

- Ou como o caderno novo quando a gente o principia.

- E belo porque o novo todo o velho contagia. João Cabral de Melo Neto, Morte e Vida Severina

Os cadernos foram os suportes de escrita mais utilizados na sala de aula estudada. Todos os alunos ${ }^{2}$ faziam quase que diariamente uso de cadernos.

O dicionário Houaiss apresenta a seguinte definição para o verbete 'caderno': "conjunto de folhas de papel em branco ou nas quais se imprimem pautas, quadrículas, ornamentos etc., reunidas, encasadas e geralmente grampeadas, costuradas ou presas com espiral, para anotações, desenhos, colagens, exercícios escolares etc."

Considerando-se os aspectos físicos dos cadernos, a diversidade vigorou. Havia cadernos grandes, chamados de universitários. Havia cadernos pequenos. Alguns com grande número de folhas e subdivisões para matérias, outros mais finos. A encadernação podia ser tipo brochura ou com espiral. Nas capas foi possível encontrar personagens de desenhos, imagens de pessoas - algumas famosas, outras não imagens de animais, propagandas de emissoras de rádio, revistas ou refrigerantes 3 . Apenas uma característica era padrão: todos os cadernos eram pautados e as linhas tinham aproximadamente oito milímetros de distância entre elas.

\footnotetext{
${ }^{2}$ Apenas um dos alunos da sala utilizou-se menos dos cadernos, pois adotou como suporte para diversas atividades a pasta fichário.

3 Interessante análise sobre as capas dos cadernos é apresentado por Mignot (2005). Além de fazer uma análise histórica, a autora estudou publicações direcionadas aos comerciantes do mercado de papelarias e apresenta as idéias subjacentes à atual colossal produção de cadernos. Nas revistas especializadas, os cadernos são descritos como algo que deve provocar nos alunos a sensação de que estão "entrando no próprio quarto", como se os cadernos fossem outdoors revelando a marca do fabricante, mas também a imagem que o possuidor do caderno deseja que os colegas tenham sobre ele. (Cadernos para todos os gostos. In: Papel \&Arte, n¹1, p.14, set/out. 1995 apud Mignot, 2005)
} 
A escola não estabeleceu regras e a aquisição dos cadernos coube às famílias dos alunos, que utilizaram critérios variados na escolha: preço, preferência da criança, disponibilidade do produto.

Pesquisadora:Você que escolheu?

Fabiana: (acena com a cabeça, em sinal de afirmação)

Pesquisadora: Foi?Você foi junto?

Fabiana: Não, minha mãe não foi, daí eu fui com um homem,um vizinho meu e uma vizinha. Daí a gente foi lá, daí eu escolhi esse.

Pesquisadora: Você gosta dele?

Fabiana: Gosto!

(Entrevista com Fabiana e Alex)

No caso de Fabiana, o caderno escolhido foi um caderno universitário, de capa dura e espiral, 200 folhas e subdivisões para as diferentes matérias. Esse foi citado como o tipo preferido pelos alunos.

Igor explicou a razão para preferir as encadernações com espiral às brochuras:

Igor: A capa é mole e a folha dá pra arrancar. Esse daí (caderno brochura), se arranca uma folha, sai todas!

(Entrevista com Ralph e Igor)

Ralph também declarou sua preferência pelas espirais, por serem mais fáceis de manusear e permitirem que o caderno seja aberto e dobrado, deixando apenas uma das folhas exposta. Explicou as dificuldades existentes, no caso da encadernação brochura, em fazer o mesmo procedimento. Quanto à capa, são ressaltadas as questões de conservação:

Ralph: E eu gosto de capa dura! Porque quando é capa mole assim, eles ficam estragando!

(Entrevista com Ralph e Igor)

As capas duras, apesar de desejadas, eram raras na classe observada. São materiais caros, que podem custar mais do dobro de um caderno de apresentação mais modesta. Dessa forma, alguns alunos têm que se resignar àquilo que suas famílias podem thes proporcionar. 
Além da aquisição pelas famílias, ocorreram doações. Silvia providenciou cadernos para todos os alunos:

Silvia apresenta à sala de aula um conjunto de cadernos brochura pequenos, com o Senninha na capa. Explica: "Comprei com o meu dinheiro porque vai ficar melhor pra mim. Várias atividades de escrita de texto vocês vão fazer aqui."

Esse caderno era usado especialmente para textos. Quando Silvia saiu e Malu assumiu a sala, o caderno passou a ser menos utilizado.

Também houve uma empresa da região que doou alguns cadernos aos alunos. Novamente foram cadernos pequenos, brochura e de capa mole.

Pesquisadora: Mas esse aqui (um caderno universitário) foi a Gonvarri ${ }^{4}$ que deu?!

Igor: Não, não. Até parece, um cadernão desse. Só pequenininho!

Raph: Aqui, olha, está escrito aqui, olha: 'uma contribuição da Gonvarri Brasil'.

Pesquisadora: Você falou cadernão desse, grande. De qual caderno você gosta, qual caderno você acha mais bacana?

(Os dois apontam para o caderno maior, o que não é distribuído pela empresa)

Ralph: Eu não gosto de caderno pequeno!

(Entrevista com Ralph e Igor)

\section{III.1.2 AS “FOLHINHAS”}

Diferentemente de caderno ou de prova, folhinha não é um verbete de dicionário. No entanto, na sala de aula estudada, esse nome foi consagrado pelo uso. Fisicamente, as folhinhas caracterizavam-se por serem sempre folhas avulsas utilizadas para atividades didáticas. Tais características, porém, não bastam para descrevê-las. A fim de abranger a complexidade de utilizações desse suporte, as folhinhas foram divididas em três tipos.

\footnotetext{
${ }^{4}$ Indústria siderúrgica.
} 
O primeiro tipo abrange aquelas que apresentavam textos didáticos, xerocados ou mimeografados, previamente preparados pela professora para cada um dos alunos da sala de aula. Os alunos guardavam-nas soltas ou coladas em uma folha de caderno.

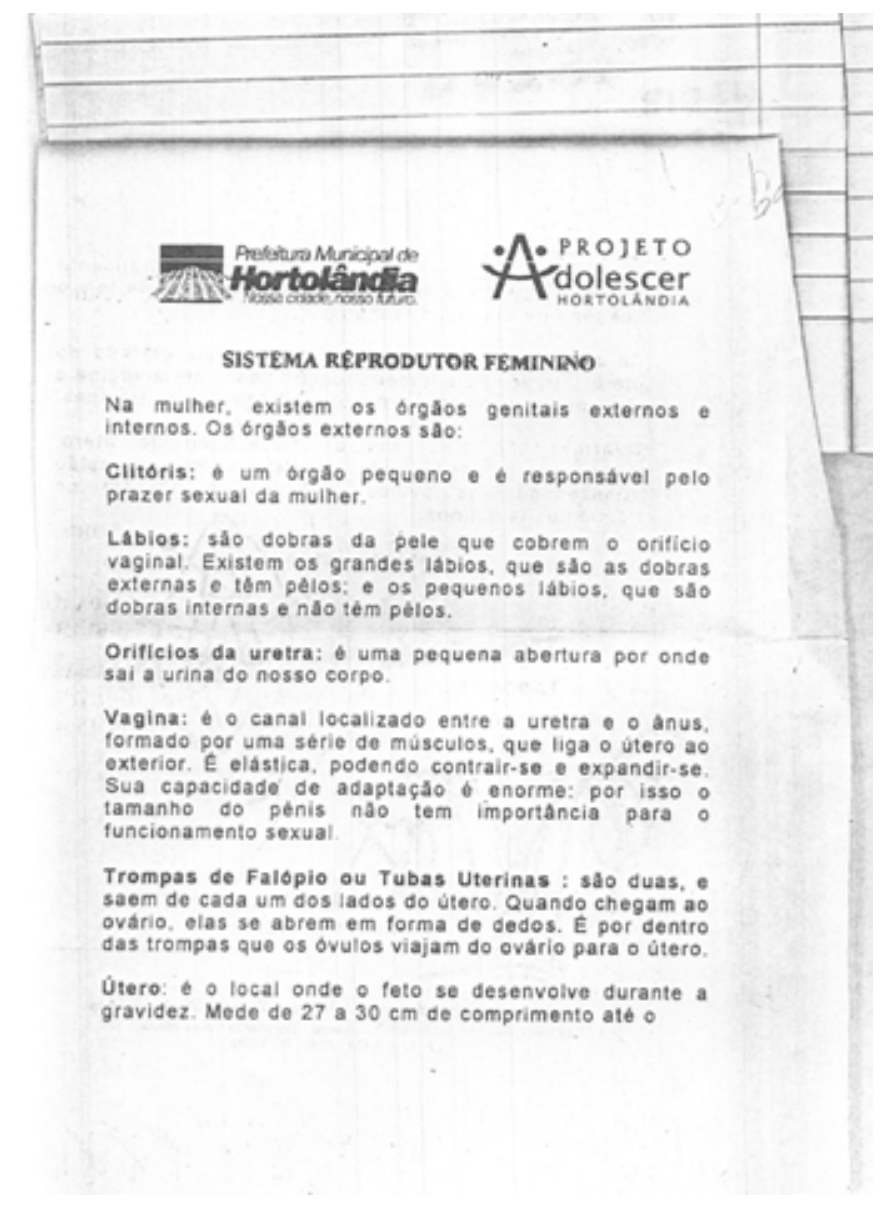

Figura 3. Folhinha do Projeto Adolescer, colada em caderno de aluno ${ }^{5}$

\section{${ }^{5}$ Sistema Reprodutor Feminino}

Na mulher, existem órgãos genitais externos e internos. Os órgãos externos são:

Clitóris:é um órgão pequeno e é responsável pelo prazer sexual da mulher.

Lábios: são as dobras da pele que cobrem o orifício vaginal. Existem os grandes lábios, que são as dobras externas e têm pêlos; e os pequenos lábios, que são dobras internas e não têm pêlos.

Orifícios da uretra: é uma pequena abertura por onde sai a urina do nosso corpo.

Vagina: é o canal localizado entre a uretra e o ânus, formado por uma série de músculos, que liga o útero ao exterior. É elástica, podendo contrair-se e expandir-se. Sua capacidade de adaptação é enorme: por isso o tamanho do pênis não tem importância para o funcionamento sexual.

Trompas de Falópio ou Tubas Uterinas: são duas, e saem de cada um dos lados do útero. Quando chegam ao ovário, elas se abrem em forma de dedos. É por dentro das trompas que os óvulos viajam do ovário para o útero.

Útero: é o local onde o feto se desenvolve durante a gravidez. Mede de 27 a $30 \mathrm{~cm}$ de comprimento até $o[\ldots]$ 
O segundo tipo engloba as folhinhas preenchidas por enunciados de exercícios ou parte de enunciados. Em alguns casos, havia espaço na própria folhinha para que fosse realizada a resolução. Terminada a atividade, a folhinha era colada no caderno. Entretanto, era mais comum a professora recomendar que as folhinhas fossem coladas nos cadernos para que os alunos fizessem a resolução abaixo. Assim aconteceu em uma aula do mês de março, quando Silvia distribuiu as seguintes folhinhas para a sala:

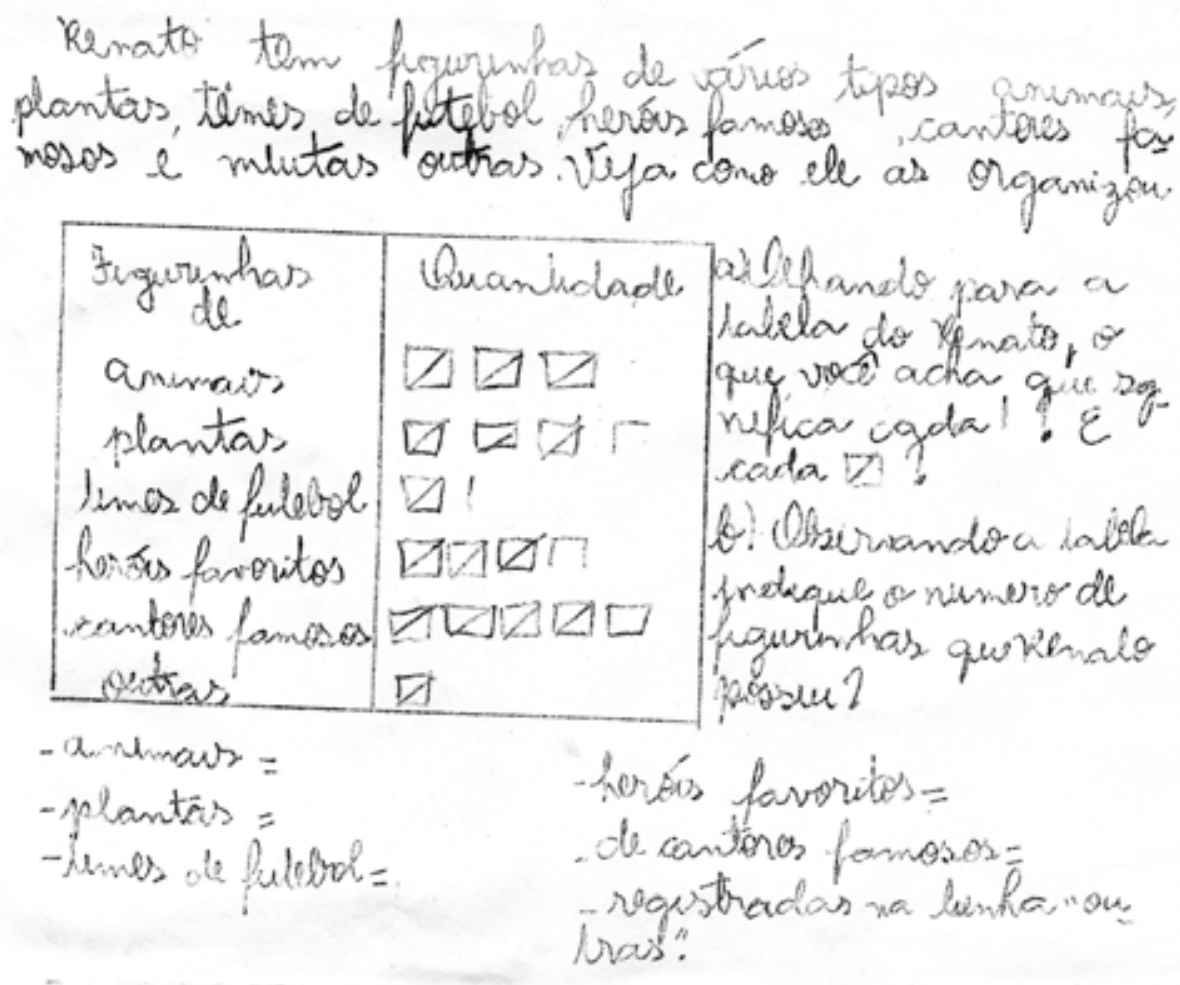

Figura 4. Folhinha com enunciado de atividade ${ }^{6}$

${ }^{6}$ Renato tem figurinhas de vários tipos: animais, plantas, times de futebol, heróis famosos, cantores famosos e muitas outras. Veja como ele as organizou

\begin{tabular}{|c|c|c|}
\hline $\begin{array}{l}\text { Figurinhas de } \\
\text { animais } \\
\text { plantas } \\
\text { times de futebol } \\
\text { heróis favoritos } \\
\text { cantores famosos } \\
\text { outras }\end{array}$ & $\begin{array}{l}\text { Quantidade } \\
\square \nabla \square \\
\square \square \square\ulcorner \\
\square । \\
\square \square \square ா \\
\square \square \square \square \square \\
\square\end{array}$ & $\begin{array}{l}\text { a) Olhando para a tabela do } \\
\text { Renato o que você acha que } \\
\text { significa cada I ? E cada } \square \text { ? } \\
\text { b) Observando a tabela, indique } \\
\text { o número de figurinhas que } \\
\text { Renato possui. }\end{array}$ \\
\hline $\begin{array}{l}\text { animais = } \\
\text { plantas }= \\
\text { times de futebol = }\end{array}$ & & $\begin{array}{l}\mathrm{S}= \\
\text { mosos = } \\
\text { linha “outras". }\end{array}$ \\
\hline
\end{tabular}


Após ler o exercício para a sala, fazer uma pequena correção no texto e dar explicações a respeito de como deveriam resolver o problema proposto:

Silvia dá, também, algumas indicações mais práticas em relação à realização da atividade. [“Aí, não tem espaço pra responder aí. Depois que vocês colarem no caderno, vocês fazem no caderno."]

O último tipo de folhinha também apresentava um enunciado - mimeografado, xerocado ou copiado pelo aluno - e sempre continha espaço destinado à resolução. Essas folhinhas não eram destinadas a ser coladas nos cadernos, mas deveriam ser entregues à professora assim que os alunos finalizassem a atividade ${ }^{7}$. Nessas folhinhas havia espaços para que os alunos preenchessem com sua identificação.

Enquanto o primeiro e segundo tipo de folhinhas invariavelmente eram preparados em folhas de sulfite, o terceiro apresentava maior diversidade de papéis base. Além das folhas de sulfite, folhas de papel almaço ou arrancadas de cadernos foram utilizadas.

Os dois primeiros tipos de folhinhas estariam abarcados se o objeto de estudo da presente pesquisa fosse unicamente os cadernos escolares. Afinal, acabam fazendo parte dos cadernos ao serem colados nas páginas desse suporte de escrita. No entanto, as folhinhas entregues à professora escapariam ao foco das atenções.

As folhinhas foram um dos recursos utilizados em 12 dos 32 dias em que se realizaram as observações. Ou seja, estiveram presentes em mais de um terço das oportunidades em que se recolheram as informações. Se, porém, se considerarem apenas as folhinhas do terceiro tipo descrito, que não passam a fazer parte do conteúdo dos cadernos, foi possível acompanhar apenas dois momentos em que esse recurso foi utilizado. Ou seja, em menos de $7 \%$ dos dias em que foram realizadas observações houve a utilização desse tipo de suporte.

\footnotetext{
${ }^{7}$ Mesmo nesse caso houve folhinhas que, depois de algum tempo, após serem corrigidas pela professora, vieram a ser coladas nos cadernos.
} 
Fica evidente que, em última instância, havia o predomínio da utilização dos cadernos nessa sala de aula.

\section{III.1.3 PROVA}

O dicionário Houaiss define o verbete 'prova' da seguinte maneira: "trabalho escolar, geralmente composto de uma série de perguntas, que tem por finalidade avaliar os conhecimentos do aluno; teste, exame".

Fisicamente, pode-se afirmar que as provas se assemelhavam ao terceiro tipo de folhinha descrito na seção anterior. Eram folhas avulsas, previamente preparadas. Então, por que considerá-las separadamente? Por que não incluí-las como um tipo específico de folhinha? A resposta a essas perguntas reside no significado atribuído socialmente às provas. Ainda que menos presentes que outros suportes de escrita, as provas têm uma significação mais definida, marcadamente avaliativa e bastante distinta das folhinhas. Despertam sentimentos diversos, em geral, negativos, tanto por parte dos alunos quanto por parte de professores.

Em primeiro lugar, as provas continham espaços para a identificação dos alunos: nome da escola, nome do aluno, série e data. Abaixo, o título 'Avaliação de...' indicava a disciplina em questão. Em seguida, havia os enunciados de exercícios e espaços reservados para as respostas.

Após concluírem a avaliação, os alunos deviam entregá-las à professora. Depois da correção, voltavam a ter contato com o material. As provas foram propostas por Silvia e por Malu. Valéria não utilizou esse recurso de avaliação.

As provas aconteceram com mais freqüência no primeiro semestre. Silvia preparou avaliações ao final do primeiro bimestre e antes de sua saída do comando da sala de aula, buscando abranger todas as disciplinas. Malu propôs provas apenas ao final do ano letivo, em meados de novembro, e restringiu-se às disciplinas Português e Matemática. 


\section{III.1.4 A PREVALÊNCIA DOS CADERNOS}

A presente pesquisa propôs-se a dirigir atenção aos mais variados suportes de registro utilizados na sala de aula estudada.

Verificou-se que, em alguns momentos, eram utilizadas folhas soltas para a realização de textos. Na maioria das vezes, essas folhas, depois de devidamente preenchidas pelos alunos, eram coladas nos cadernos, passando a fazer parte desse suporte de escrita. As provas foram um recurso utilizado em momentos circunscritos.

Sem desconsiderar a importância de folhinhas e provas no modo de organização da sala de aula, o que pôde ser identificado foi a predominância absoluta dos cadernos. A realização dos registros se centrava nos cadernos, eram esses os materiais usados diariamente, servindo de suporte para várias das atividades desenvolvidas ao longo de um dia letivo.

Assim, serão os cadernos que comparecerão de maneira mais significativa na descrição a respeito da utilização de suportes de escrita na sala de aula em questão. Os demais suportes serão citados e descritos à medida que possibilitem melhor caracterizar o contexto estudado.

\section{III.2 QUEM REGISTRA?}

Estudar os registros realizados, predominantemente, pelos alunos não significa dirigir a atenção unicamente àquilo que o corpo discente registra. Muitas são as mãos que participam do conjunto de registros. A seguir, serão apresentadas as participações dos alunos, suas professoras e famílias.

\section{III.2.1 ALUNOS}

Os cadernos são primordialmente preenchidos pelos alunos. Na sala de aula em questão, cada caderno tinha um dono, ou seja, cabia a um aluno. 
Quase sempre esses cadernos apresentavam algum tipo de identificação que indicava a quem pertencia cada caderno. Por vezes, a indicação do proprietário se dava mais formalmente, por meio de etiquetas coladas à capa. Outras vezes, apenas podiam ser encontrados nomes escritos na capa, contracapa ou primeira folha do caderno. Cada caderno foi preenchido primordialmente pelo aluno a quem pertencia.

Uma peculiaridade da sala de aula estudada foi a presença significativamente maior de meninos que de meninas ${ }^{8}$. De modo geral, as meninas tinham cadernos com melhor apresentação que os meninos. A questão de gênero e o modo pelo qual se articula com a produção de registros será retomada adiante, na seção III.4.3 deste capítulo.

Os alunos diferiam quanto ao domínio da leitura e da escrita. Alguns começaram o ano sendo capazes de produzir textos simples e de ler com razoável fluência. Mas essa não era uma realidade para o conjunto da sala. Nos primeiros dias, Silvia demonstrou que os alunos não correspondiam às suas expectativas:

Comenta estar muito decepcionada com os conhecimentos das crianças da sala. Avalia que esta quarta série tem nível de segunda.

Em junho, Silvia demonstrava identificar progressos. Ainda assim relatou que ainda havia muitos alunos com dificuldades ortográficas e com a estrutura do texto (por exemplo, uso de parágrafo ou título).

Jordan, aluno que acabou sendo retido ao final do ano, era um dos que mais preocupava a professora:

Porque ele, assim, começou a ler agora, começou a escrever agora... então ele não tem assim o domínio da leitura e da escrita. Ontem a gente fez a prova de português (...) Aí ele pegou e escreveu. Escreveu não, né? Sabe igual criança que faz um monte de letra assim? Ele fez isso!

(Entrevista com Silvia)

\footnotetext{
${ }^{8}$ Houve um certa rotatividade de alunos na sala de aula, que teve uma média de 33 alunos ao longo do ano. Da turma inicial, saíram cinco. Porém, entraram seis alunos. Dos 39 alunos que passaram pela sala, apenas 10 eram meninas.
} 
Essa diversidade nos níveis de domínio de leitura e escrita imprimiam diferenças aos registros que comparecerão nos exemplos de produções apresentadas ao longo deste capítulo.

Na maioria do tempo, era o próprio aluno, dono do caderno, quem executava os registros. A prática segundo a qual um aluno fizesse as atividades por outro não foi estimulada e, por vezes, chegou a ser repreendida. No entanto, houve alguns momentos em que a professora solicitou que um aluno escrevesse no caderno do colega. Esses momentos, ainda que restritos e pouco freqüentes, aconteciam articulados a objetivos didáticos das professoras.

Um exemplo desse tipo de procedimento ocorreu nos últimos dias de Silvia com a sala de aula. A professora organizou uma prova para avaliar os alunos. Alguns faltaram no dia em que a avaliação ocorreu e então tiveram a oportunidade de realizá-la no dia seguinte. Enquanto isso, os demais alunos faziam uma atividade de português: deviam copiar um poema e responder a questões relativas ao texto. Para que os alunos envolvidos com a realização da prova pudessem realizar a atividade mais tarde, Silvia solicitou a outros alunos que copiassem o texto e as perguntas a ser respondidas:

Sandro vai fazer a prova. Cleber assume o caderno do colega e continua a cópia para que ele possa fazer a avaliação. (...) Igor copia para Heitor que também faz a prova.

Malu, por sua vez, propôs uma atividade na qual os próprios alunos deveriam corrigir os cadernos de seus colegas:

Vejo o caderno de Talita. Há uma espécie de bilhete em seu no caderno. Uma anotação com letra de criança dizendo: "seu caderno está uma maravilha".

Pergunto a ela quem escreveu. Ela me explica que foi Walkíria. A professora propôs que os alunos trocassem os cadernos e cada um devia avaliar o do colega. 
Valéria propôs uma atividade na qual alunos deveriam escrever nas folhinhas de outros. A atividade foi realizada em uma folha de papel em branco. Cada aluno tinha a sua e ali deveria escrever seu nome e uma qualidade que acreditava ter. Em seguida, a folhinha passou a circular pela sala, e todos os alunos deveriam escrever qualidades nas folhinhas de todos os outros.

Em outros momentos, os alunos intervinham nos cadernos de seus colegas independentemente de isso ser proposto pela professora.

Walkíria é ajudada por Uelinton para escrever 'cirurgião'. Menina sentada à sua frente lê o que Walkíria escreveu e faz correções no caderno de Walkíria.

\section{III.2.2. PROFESSORAS}

As professoras foram responsáveis por alguns tipos específicos de registros: correções, enunciados de exercícios e bilhetes.

\section{III.2.2.1 Correções}

A correção dos cadernos era uma atribuição que oscilava entre caber aos próprios alunos e ser realizada pelas professoras. 0 mais comum era que a correção fosse feita na lousa e cada aluno fizesse a autocorreção em seu caderno. Em outros momentos, a professora passava pelas carteiras, verificando as atividades. Mais raramente, os cadernos eram entregues às professoras que os levavam para casa e realizavam a correção. Somente foi possível observar tal procedimento em relação aos cadernos de textos.

Folheando os cadernos, encontraram-se diversos breves registros elaborados pelas professoras, tais como grandes letras $C$, indicando que a atividade estava correta: 


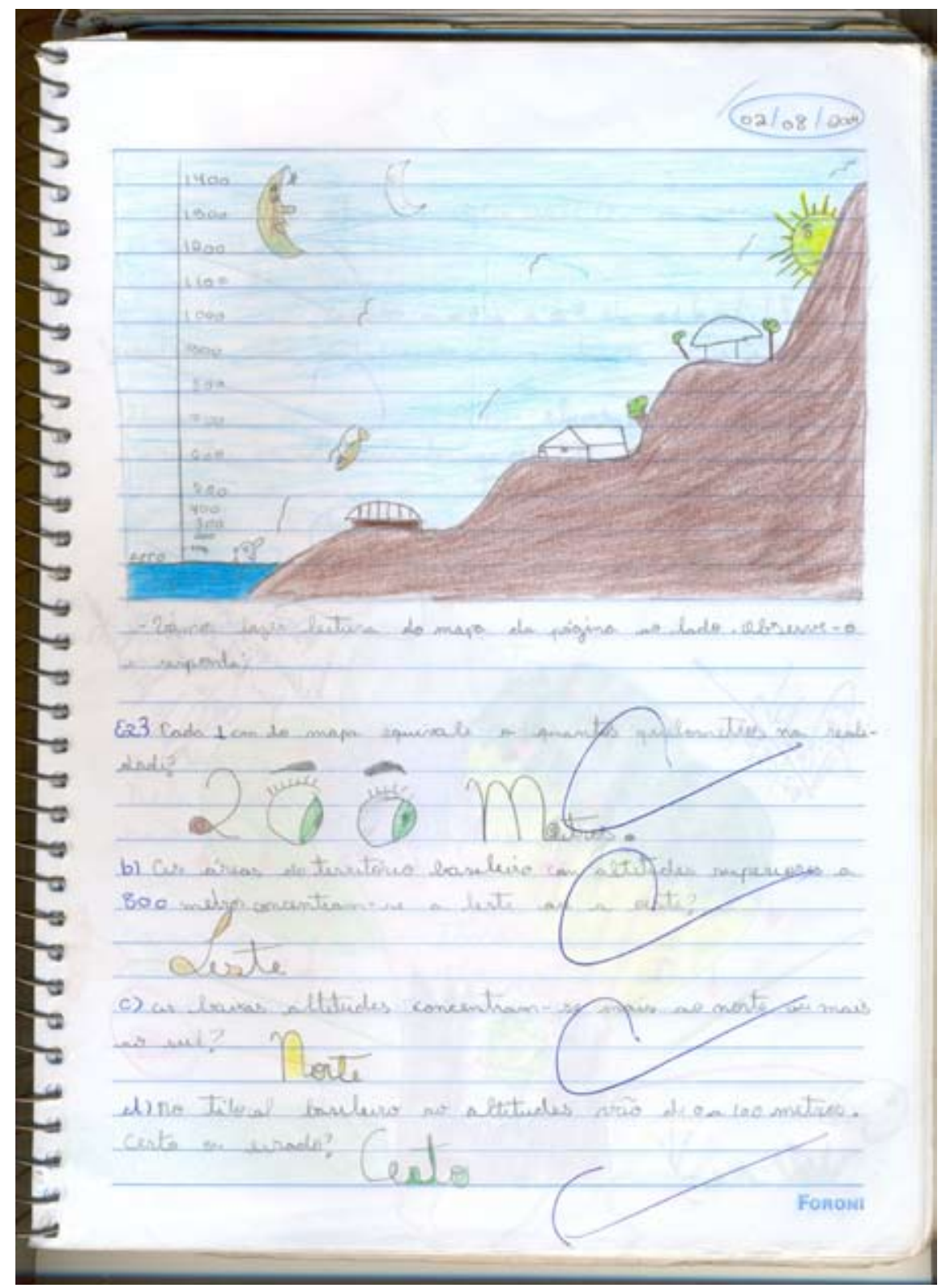

Figura 5. Caderno de Ralph, corrigido por Malu9

\section{Comentários elogiando ou sugerindo melhoras:}

\footnotetext{
9 Vamos fazer leitura do mapa da página ao lado. Observe-o e responda:

a) Cada $1 \mathrm{~cm}$ do mapa equivale a quantos quilômetros na realidade? 200 metros.

b) As áreas do território brasileiro com altitudes superiores a 800 metros concentram-se a leste ou oeste? Leste

c) As baixas altitudes concentram-se mais ao norte ou mais ao sul? Norte

d) No litoral brasileiro ao altitudes vão de 0 a 100 metros. Certo ou errado? Certo
} 


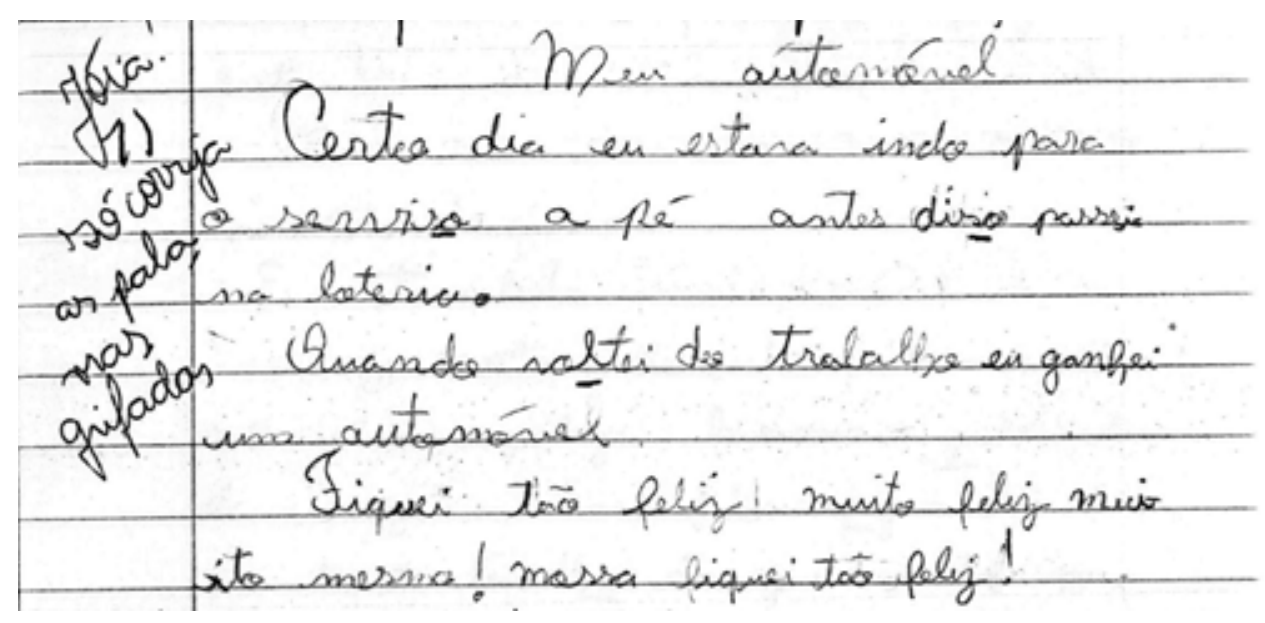

Figura 6. Caderno de textos da aluna Jenifer, corrigido por Silvia ${ }^{10}$

As correções de erros foram mais raras de serem encontradas. Especialmente Silvia raramente as utilizava, preferindo indicar que havia algo errado e solicitando que o próprio aluno fizesse de modo correto. Assim mostra a figura anterior e a cena a seguir:

Aluno volta da mesa de Silvia com três contas corrigidas como certas. Duas delas não estão corrigidas, são as que não estão corretas e que ele tem que corrigir.

Nas observações, foi possível verificar que as professoras utilizavam com freqüência a estratégia de indicar verbalmente aos alunos aquilo que deveria ser refeito.

No entanto, nem sempre é possível saber quem realizou as correções. Os alunos passaram a dominar tão bem a técnica de corrigir, utilizando os mesmos recursos que as professoras, que muitas vezes era difícil, para alguém que observasse unicamente os registros dos cadernos, identificar quais eram as correções feitas pela professora e quais o próprio aluno tinha feito.

10 “Meu automóvel

Certo dia estava indo para o serviso a pé antes diso passei na loteria.

Quando voltei do trabalho qu ganhei um automóvel.

Fiquei tão feliz! Muito feliz muito mesmo! Nossa fiquei tão feliz!"

Correção da professora: "Jóia. Só Corrija as palavras grifadas." 


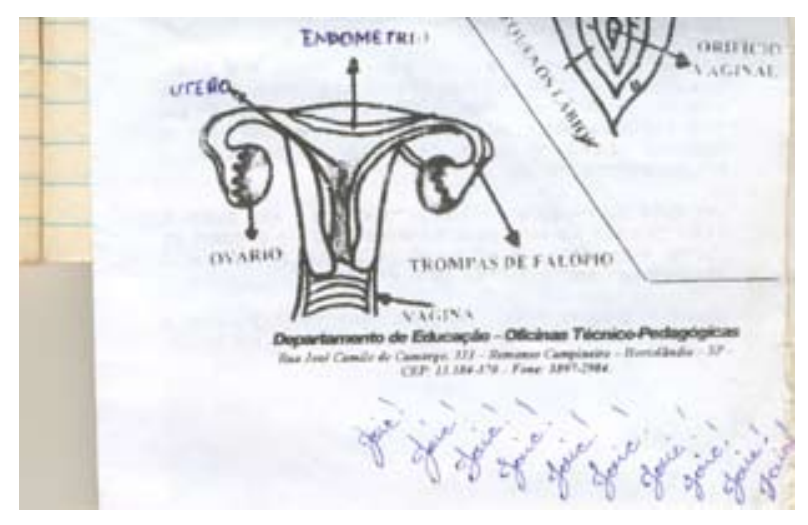

Figura 7. Caderno de Alex com folhinha colada

Na imagem acima, é possível ver a palavra jóia escrita diversas vezes por Alex. Ainda que a sequiência de palavras repetidas pareça estranha e difira daquilo que a professora costumava fazer, a letra e o traçado são bastante semelhantes ao modo pelo qual a professora Silvia escrevia nos cadernos de seus alunos ${ }^{11}$. Na entrevista, ele contou:

Alex: Tudo jóia. Eu inventando jóia da professora Silvia (eles riem). Pesquisadora: Foi você que fez?

Alex: Foi. Escrevi um monte! (...)

Pesquisadora: Nessa época a Silvia já tinha ido embora, não é? A: Tinha, mas eu gostava de imitar ela.

(Entrevista com Fabiana e Alex)

\section{III.2.2.2 Trechos de exercícios}

Silvia adotou o procedimento de, em alguns momentos, dar atividades diferenciadas para alguns poucos alunos que estavam mais atrasados em relação à aquisição da leitura e da escrita:

Pesquisadora: E você tem feito coisas diversificadas ou não? Silvia: Com a Lauriane, às vezes eu faço, às vezes não. Com o Jordan, às vezes eu faço, às vezes não.

(Entrevista com Silvia)

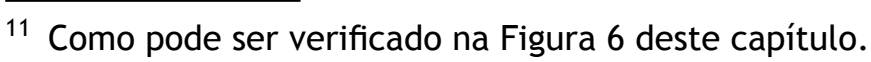


Apesar de a professora alegar que gostaria de preparar atividades diferentes com antecedência, em sua casa, raramente isso foi possível. Diante da falta de tempo, a solução encontrada era escrever à mão, nos cadernos desses alunos, exercícios a ser realizados:

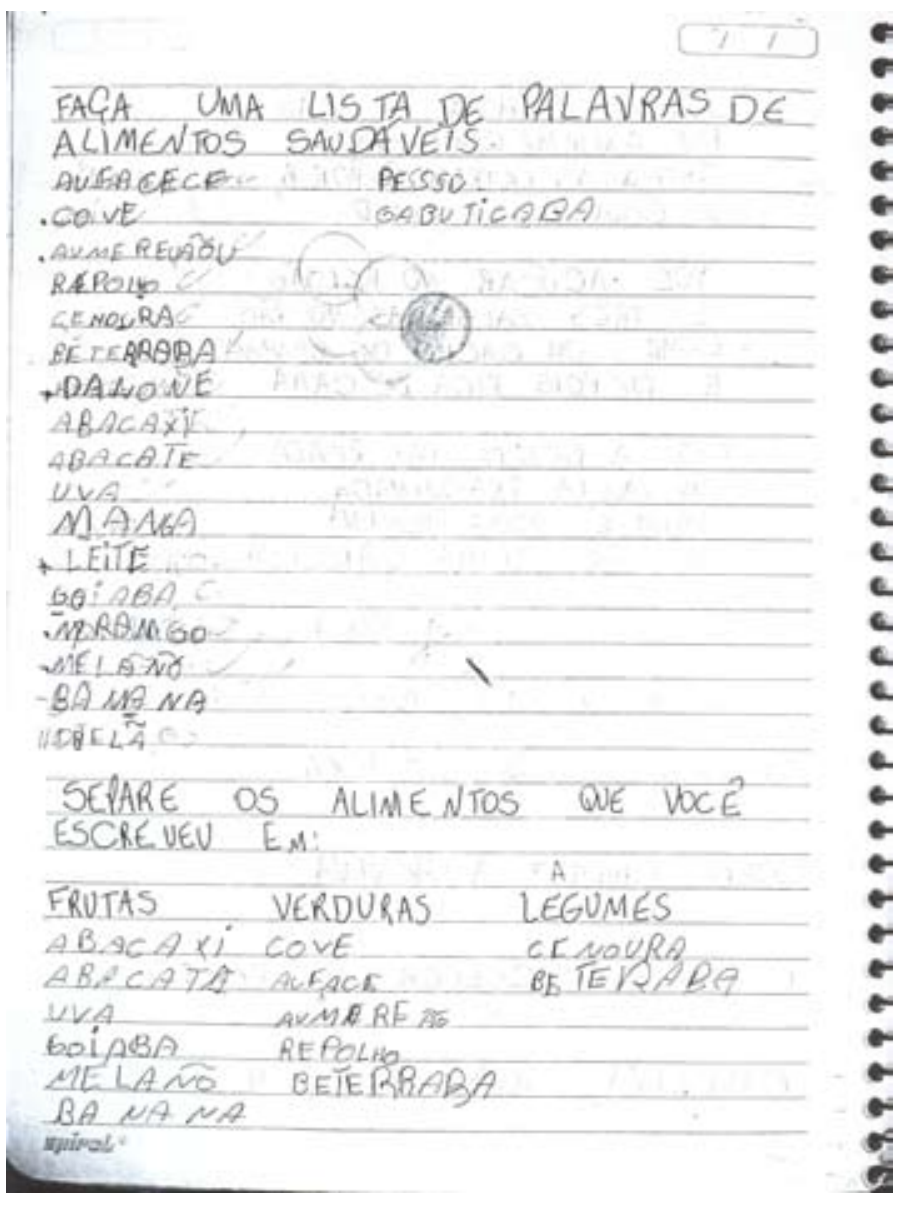

Figura 8. Exercícios escritos pela professora no caderno de Jordan ${ }^{12}$

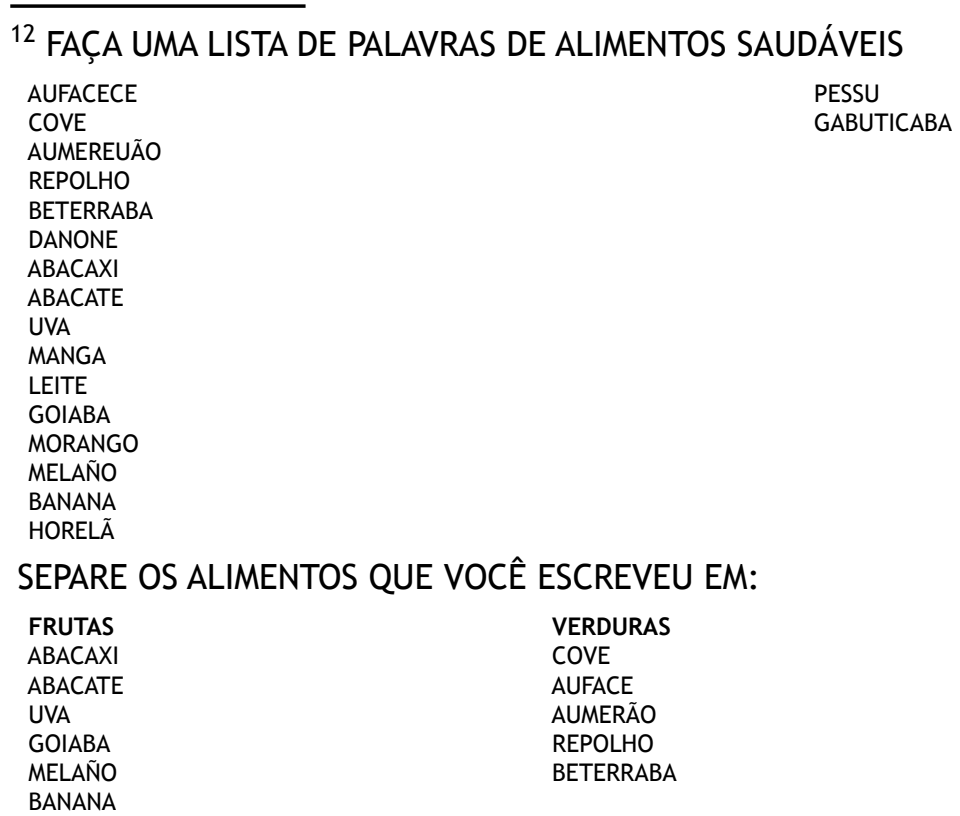

LEGUMES

CENOURA

BETERABA 


\section{III.2.2.3 Bilhetes}

Os bilhetes são comunicações feitas por escrito no caderno do aluno. Esse recurso, que foi anteriormente abordado em outro trabalho (SANTOS, 2002), tem se mostrado bastante presente nas salas de aula.

Tanto Silvia quanto Malu recorreram a essa forma de comunicação. As comunicações encontradas referiam-se, especialmente, a questões disciplinares e/ ou ao não cumprimento das tarefas escolares solicitadas, como se pode perceber no texto do bilhete a seguir:

Mãe, gostaria que conversasse com seu filho diante das atitudes dele em sala de aula. Faz as lições pela metade e sem nenhum capricho, fala muito, reclama e discute com os colegas. Por favor, converse com ele sobre isso. Atenciosamente, Prof ${ }^{a}$. Malu.

Favor assinar o bilhete

Hortolândia 06/10/04

\section{III.2.3 FAMÍLIA DOS ALUNOS}

As famílias não foram presenças freqüentes nos suportes de registro. Ainda assim, destaca-se a participação que irmãos e pais tiveram nos materiais dos alunos.

\section{III.2.3.1 Atividades didáticas}

Houve a participação de familiares em algumas atividades didáticas propostas pela escola, como na atividade desenvolvida em abril, na qual todos os alunos deviam produzir textos e desenhos a respeito das condições do bairro onde moravam: 
Jordan mostra o desenho e o texto que fez. Um texto escrito com grandes letras. Pergunto o que está escrito e ele diz algo que tem relação com o conteúdo, mas que não é uma leitura. Pergunto se foi ele quem escreveu. E ele diz que foi sua irmã. Pergunto: "Tudo bem a sua irmã escrever?". Ele diz que sim, que havia sido a professora quem havia dito para que ela ajudasse.

A participação acima foi prevista e incentivada pela professora. Não foi possível identificar outros momentos em que tal solicitação tenha sido feita. Também não foram observadas participações de familiares em atividades didáticas que tenham sido desaprovadas pela escola.

\section{III.2.3.2 Bilhetes}

Considerando-se que bilhetes são comunicações por escrito realizadas por meio dos cadernos dos alunos, os bilhetes escritos pelas famílias dividem-se em duas categorias: os comunicados e as respostas aos bilhetes enviados pela professora.

\section{III.2.3.2.1 Comunicados}

Uma das situações em que os pais escreviam nos cadernos de seus filhos era quando precisavam dizer algo considerado importante à professora, como mostra o comunicado a seguir:

Igor me mostra bilhete escrito pela mãe, avisando que ele faltou duas vezes por estar com febre. A mãe pede para ser avisada caso o filho volte a ter febre. 


\section{III.2.3.2.2 Respostas aos bilhetes enviados pela escola}

Ainda que o mais comum fosse que os pais não enviassem resposta por escrito aos bilhetes, alguns pais o fizeram. As respostas dos pais buscavam comunicar à professora que medidas haviam sido tomadas, ou a impossibilidade de realizar aquilo que foi pedido.

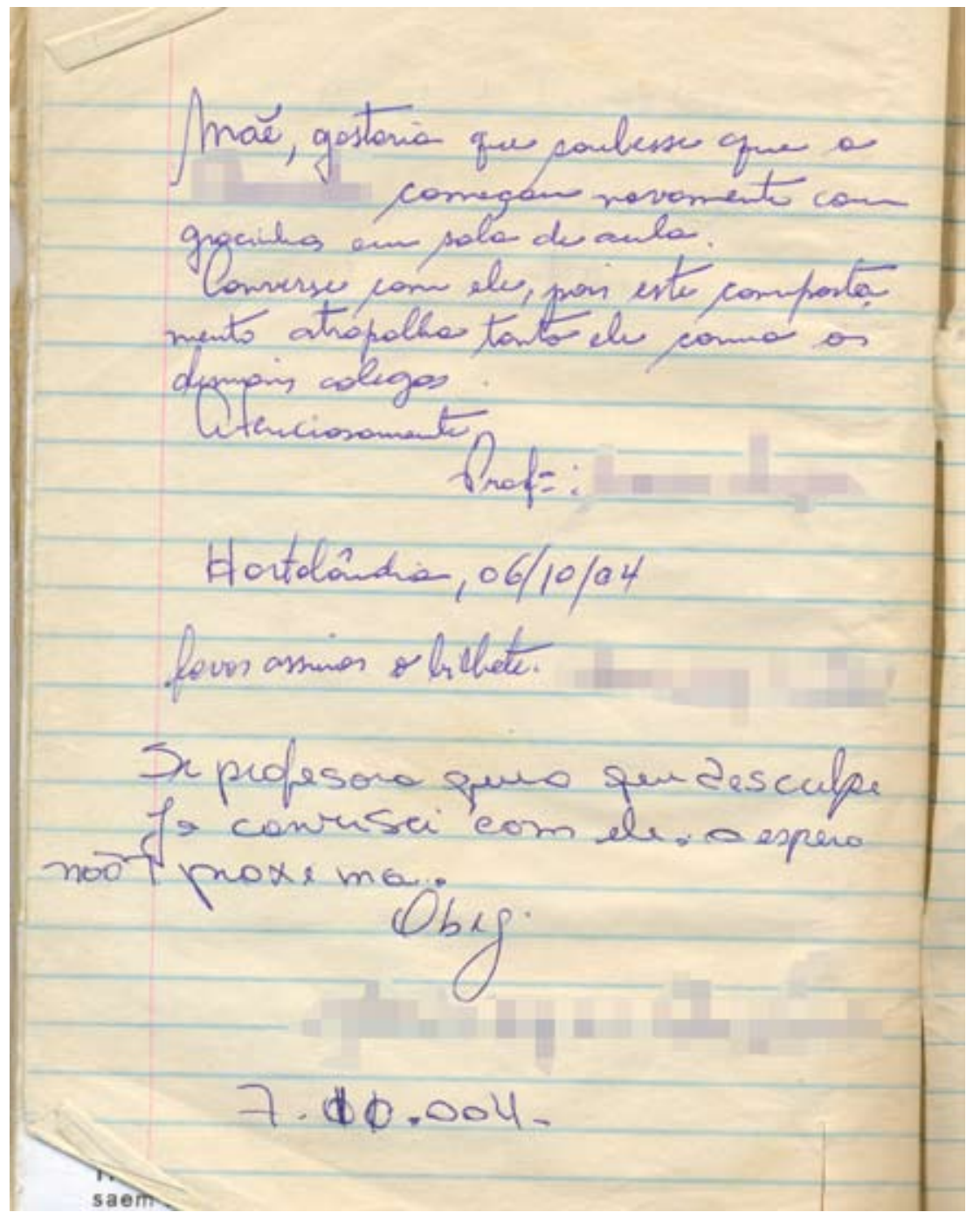

Figura 9. Bilhete escrito por professora e respondido por mãe de aluno ${ }^{13}$

\footnotetext{
${ }^{13}$ Mãe, gostaria que soubesse que o (nome do aluno) começou novamente com gracinhas em sala de aula. Conversei com ele, pois este comportamento atrapalha tanto ele como os demais colegas. Atenciosamente Prof $^{a}$ (nome da professora) Hortolândia, 06/10/04
}

Favor assinar o bilhete

Sr. professora quero que desculpe. Ja conversei com ele espero não T proxima. Obrg.7.11.004 


\section{III.3O QUE SE REGISTRA?}

\section{III.3.1 CONTEÚDOS REGISTRADOS PELOS ALUNOS QUE FORAM PROPOSTOS PELAS PROFESSORAS}

Os cadernos são, por excelência, suportes do trabalho pedagógico desenvolvido na escola. Registram textos e temas abordados e exercícios relativos a essas temáticas. A fim de detalhar a qualidade das atividades realizadas que utilizaram os cadernos como suporte, será apresentado um levantamento geral das atividades que constaram nos cadernos de uma das alunas: Fabiana. Ela participou da etapa de entrevistas e, portanto, foi apresentada no capítulo II. Era uma ótima aluna, que no geral costumava cumprir todas as atividades propostas. Passou a fazer parte da sala de aula estudada apenas em maio, quando veio do litoral com a família.

A escolha dos materiais de Fabiana para a realização do levantamento das atividades escolares registradas nos cadernos deve-se ao fato de seu caderno ser um dos mais completos da sala de aula, usado até mesmo como material de consulta para a professora:

Malu consulta o caderno de alguns alunos. Pega primeiro o caderno de Fabiana, que está sentada na primeira carteira. A professora precisa copiar na lousa o texto coletivo iniciado ontem para que possam finalizá-lo hoje.

Apesar de Fabiana ter passado a acompanhar a sala de aula apenas em meados de maio, foi ela quem me forneceu o material que abrangia mais completamente o ano letivo. Como a solicitação dos cadernos para a pesquisa pressupôs o estabelecimento de uma relação de confiança com os alunos, foi um procedimento adotado, especialmente, no segundo semestre. Assim, 
nenhum dos alunos forneceu materiais que tivessem um registro sistemático dos primeiros meses.

Fabiana forneceu para cópia dois cadernos, tipo universitário, subdivididos em matérias. 0 primeiro abrangia o período de 20 de maio a 15 de setembro; o segundo começou a ser utilizado em 9 de setembro e continha registros até 16 de novembro. Enquanto o primeiro caderno foi subdividido em cinco disciplinas (Português, Matemática, Ciências, Geografia e História), o segundo tinha apenas duas disciplinas (Português e Matemática).

Português foi a disciplina que exigiu o maior número de páginas de caderno. Durante todo o período abrangido pelo material a que tive acesso, Fabiana preencheu 61 folhas de seu caderno com atividades dessa disciplina ${ }^{14}$. A atividade mais recorrente foi a cópia de pequenos textos que ocupavam entre meia página e uma página e meia. As temáticas e os tipos de textos foram bastante variados: semana do meio ambiente, comportamento de meninas e meninos, fábulas, letras de músicas, dentre outros. Os poemas ganharam especial destaque. À maioria dos textos, sucedia uma série de questões, algumas de compreensão ou vocabulário, outras abordando aspectos gramaticais.

Alguns dos textos eram frutos de construção coletiva com a classe. Havia também produções que consistiam na reescrita de textos anteriormente elaborados por algum dos alunos. As professoras apresentavam os textos originais (na lousa ou em folhas mimeografadas) e propunham à sala que, conjuntamente, realizasse uma reescrita, visando aprimorar a redação e corrigir erros. Ao final, o texto corrigido era copiado.

\footnotetext{
${ }^{14}$ Ainda que o caderno de textos também seja relacionado à disciplina Português, não está considerado neste levantamento de número de páginas. Esse material será considerado independentemente mais adiante nesta seção.
} 


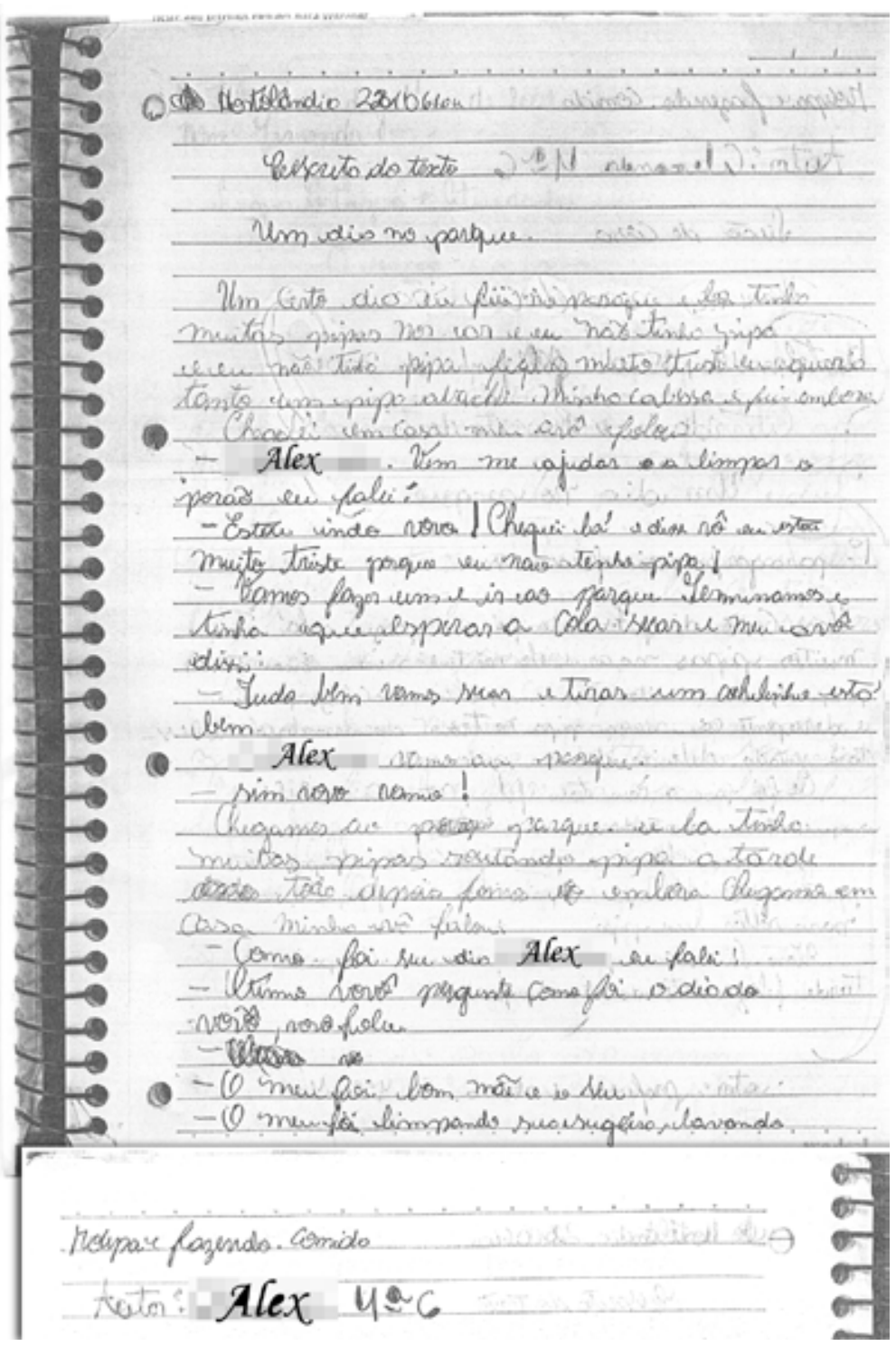

Figura 10. Texto a reescrever copiado no caderno de Fabiana ${ }^{15}$

15 Texto original:

Um dia no parque

Um certo dia eu fui no parque e la tinha muitas pipas no ar e eu não tinha pipa fiquei muito triste eu queria tanto um pipa abachei minha cabessa e fui embora

Cheguei em casa meu avô falou

- Alex. Vem me ajudar a limpar o porão eu falei.

-Estou indo vovo! Cheguei lá e disse vô eu estou muito triste porque eu não tenho pipa!

- Vamos fazer um e ir ao parque Terminamos e tinha que esperar a cola secar e meu ave disse:

- Tudo bem vamos secar e tirar um cochilinho está bem

Alex vamos au parque.

- Sim vovo vamo!

- Chegamos ao parque e la tinha muitas pipas soutando pipa a tarde todo depois fomos embora.

Chegamos em casa minha avô falou:

-Como foi seu dia Alex eu falei:

-Otimo vovô pergunte como foi o dia do vovô, vovô falou

- O meu foi bom mãe e o seu

-O meu foi limpando sua sujeira, lavando roupa e fazendo comida.

Autor: Alex $4^{\mathrm{a} C}$ 


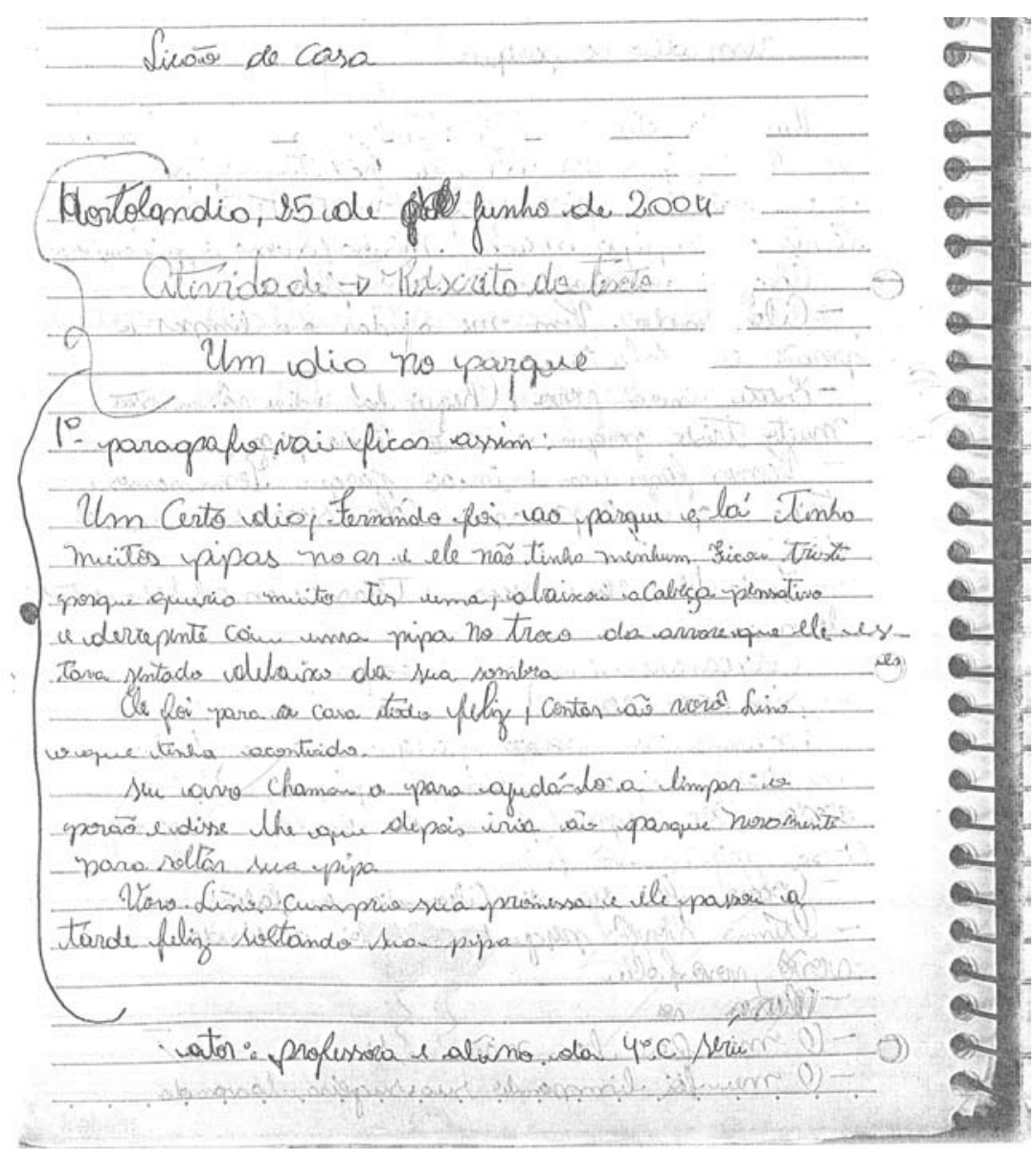

Figura 11. Texto reescrito copiado no caderno de Fabiana ${ }^{16}$

Outra atividade recorrente era a solicitação de produções de texto ${ }^{17}$. Os temas propostos foram bastante variados, a saber, o país, a cadeia alimentar, a peça de teatro que a classe acabara de assistir, o dia das crianças etc.

16 Texto reescrito:

Um certo dia, Fernando foi ao parque e lá tinha muitos pipas no ar e ele não tinha nenhuma. Ficou triste porque queria muito ter uma, abaixou a cabeça pensativo e derrepente caiu uma pipa no tronco da arvore que ele estava sentado debaixo da sua sombra.

Ele foi para casa todo feliz, contar ão vovô Lino o que tinha acontecido.

Seu avo chamou o para ajudá-lo a limpar o porão e disse the que depois iria ão parque novamente para soltar sua pipa

Vovo Lino cumprio sua promessa e ele passou a tarde feliz soltando sua pipa Autor: professora e aluno da $4^{\mathrm{a} C}$ série

${ }^{17}$ As produções de texto tiveram diversos suportes: o caderno de Português, o caderno de textos e as folhinhas. 
Algumas atividades de ortografia também puderam ser encontradas. Foram apresentadas palavras com a falta de algumas letras. Os alunos deveriam preencher os espaços com $l$ ou $u, m$ ou $n$. Um único ditado e um acróstico foram registrados no material da aluna.

Matemática foi a segunda disciplina a ocupar maior número de páginas nos cadernos de Fabiana. Durante todo o ano, 51 páginas foram utilizadas para realizar as atividades relativas a essa matéria. As atividades de Matemática tinham características próprias, bastante definidas e diferenciadas dos demais conteúdos escolares ministrados nos primeiros anos do ensino fundamental. Basicamente, os registros consistem em atividades a ser realizadas pelos alunos. Ao longo de todo ano, foi recorrente a resolução de problemas. Os temas presentes nas situaçõesproblema foram muito variados: venda de ovos, número de páginas de livros, figurinhas, valor de compras, litros de vinho, latas de azeitona, espectadores de um jogo, entre outros.

Alguns exigiam um raciocínio pouco complexo e a realização de uma única operação matemática, como o problema proposto em 3 de agosto cujo enunciado era:

Colei uma dúzia de figurinhas em cada página de um álbum. 0 álbum tem 66 páginas. Quantas figurinhas eu colei?

(Caderno I de Fabiana)

Outros problemas apresentavam um enunciado mais complexo e exigiam um raciocínio mais elaborado, ainda que nem sempre fossem necessárias operações mais difíceis para sua resolução. O problema a seguir pode exemplificar: 


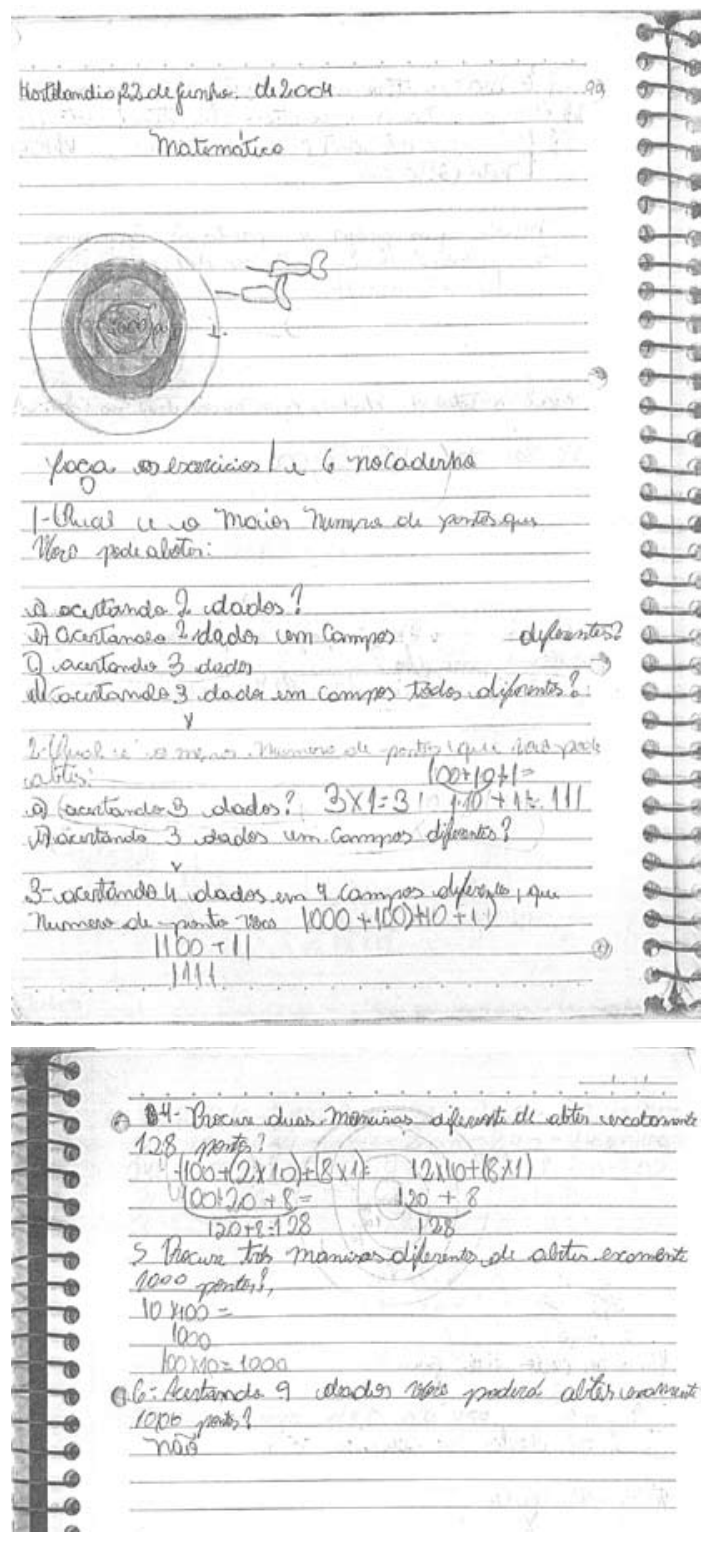

Figura 12. Problema de matemática copiado no caderno de Fabiana ${ }^{18}$

18 (Transcrição da atividade com pequenas correções e omissão dos cálculos)

Faça os exercícios 1 a 6 no caderno

1-Qual é o maior número de pontos que você pode obter
a) acertando 2 dardos?
b) acertando 2 dardos em campos diferentes?
c) acertando 3 dardos?
d) acertando 3 dardos em campos todos diferentes?

2-Qual é o menor número de pontos que você pode obter

a) acertando 3 dardos?

b) acertando 3 dardos em campos diferentes?

3-Acertando 4 dardos em 4 campos diferentes que número de pontos você faz?

4- Procure duas maneiras diferentes de obter exatamente 128 pontos.

5- Procure três maneiras diferentes de obter exatamente 1.000 pontos.

6- Acertando 9 dardos você poderá obter exatamente 1.000 pontos? 
Também eram extremamente comuns as atividades que solicitavam a resolução de operações matemáticas (somas, subtrações, multiplicações e divisões) e que os alunos escrevessem números por extenso ${ }^{19}$. Raramente eram propostas atividades cujo formato era um pouco diferente, como a atividade a seguir em que eram apresentadas operações matemáticas resolvidas, com alguns números faltando (representados por quadradinhos). Aos alunos cabia preencher os quadradinhos com os números correspondentes:
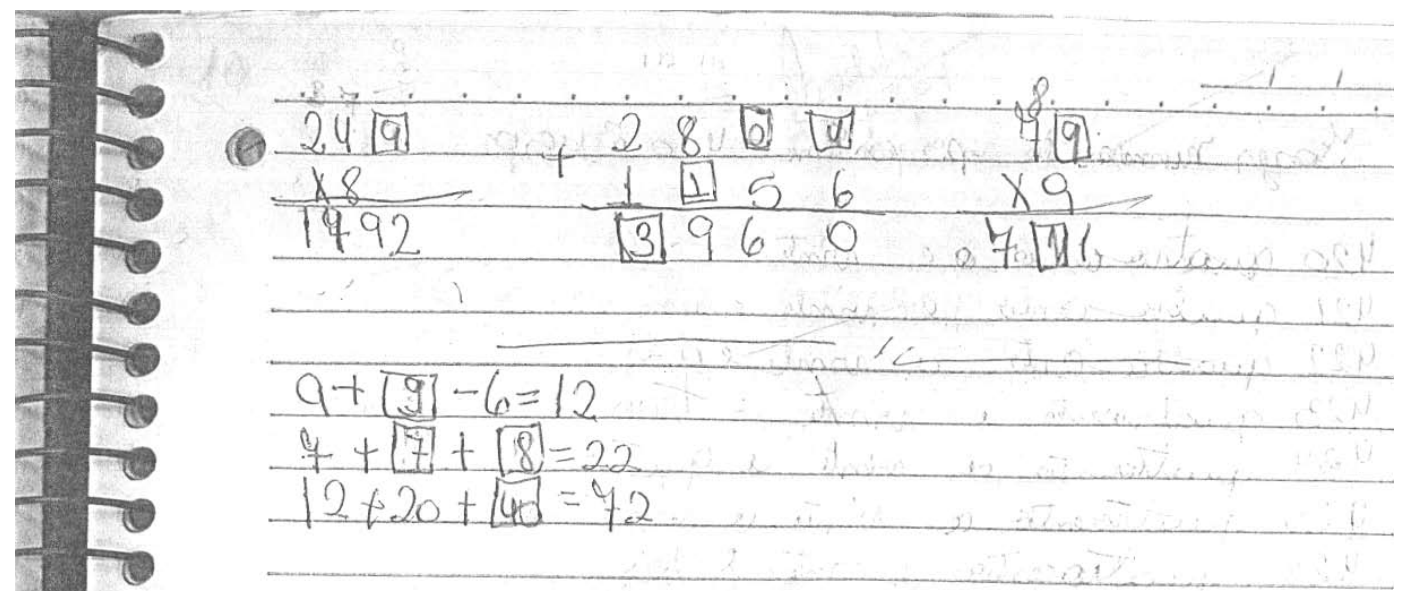

Figura 13. Atividade de matemática encontrada no caderno de Fabiana

Excetuando-se as atividades de Matemática, que são bem características, as demais disciplinas não podem ser completamente distinguidas pelo tipo de atividades e temas abordados. Por exemplo, é possível encontrar no caderno de Português uma atividade que solicita a produção de um texto cujo tema é a cadeia alimentar de animais terrestres. Algumas páginas adiante outro enunciado pede que os alunos comentem uma música que diz que a natureza chora. Ou seja, para temas tipicamente abordado em Ciências são propostas atividades semelhantes às que são solicitadas em Português. Redações também foram solicitadas em temas históricos e foram registradas no caderno de História. 0 formato cópia de texto e perguntas a responder

${ }^{19}$ Esse tipo de atividade se repetiu ao longo do ano. As seguintes seqüências foram solicitadas: 101 a 150; 150 a 200; 201 a 250; 250 a 350; 350 a 400; 400 a 420; 420 a 450, 0 a 500 de 10 em 10, 500 a 700,600 a 640 . 
compareceu em disciplinas como Português, Ciências e Geografia. No caderno de Ciências, por sua vez, é possível encontrar um texto copiado que versa sobre os direitos de seres humanos à liberdade e à dignidade. Ainda que tal tema possa ser abordado pela disciplina, não é um tema caracteristicamente abordado em Ciências. Poluição também é um tema que aparece nos cadernos de Português e de Ciências.

Esse modo de organização de temas e atividades, que faz com que não se possa reconhecer claramente à qual disciplina se refere um registro, remete a uma idéia de interdisciplinaridade. Esse conceito, há algum tempo bastante valorizado pela Educação, concebe o conhecimento de modo globalizante, rompendo as fronteiras das disciplinas (GADOTTI, 1999). Os conteúdos não teriam um pertencimento tão definido a uma área do conhecimento, sendo abordados de maneira integrada ao serem ensinados. No caso da sala de aula em questão, não se trata de uma interdisciplinaridade que faça parte de um projeto pedagógico e que tenha sido um objetivo das professoras.

Em nenhum momento, ao longo de um ano de acompanhamento da sala de aula, houve uma preocupação manifesta com essa forma de conceber o conhecimento e trabalhar com ele. 0 que ocorreu foi uma modalidade de interdisciplinaridade não planejada, quase acidental, ora proposta pelas professoras - por meio da forma de apresentar e organizar as atividades, ora assumida pelos alunos, que, ao não conseguirem encontrar diferenças evidentes entre as atividades de diferentes disciplinas, realizavam seus registros sem subdivisões. 0 caráter não intencional limita os alcances que essa abordagem não fragmentada dos saberes poderia alcançar na formação dos indivíduos, dado que não é explicitada a concepção segundo a qual as várias ciências contribuem para o conhecimento da realidade vivida.

As indicações de lições de casa a ser realizadas também constaram nos cadernos. Não são registros freqüentes e nem com uma periodicidade fixa. Foram mais freqüentes em Matemática, consistindo na resolução de problemas e operações, na escrita de numerais por extenso e realização de pesquisa de preços. Em Português, foi registrado o seguinte enunciado de lição de casa: 
Pesquise uma notícia de jornal e traga para a sala de aula para leitura.

(Caderno de Português de Fabiana, registro feito em 18 de junho) ${ }^{20}$

O caderno de Ciências foi bem menos usado, tendo apenas 18 páginas preenchidas ao longo de todo o ano. Destas, três foram reservadas ao Projeto Adolescer. Basicamente, as atividades de Ciências consistiram na cópia de textos didáticos, sucedidos por perguntas a ser respondidas. Houve uma solicitação de resumo da música "Planeta Água”. A presença de desenhos relacionados ao tema abordado foi mais expressiva em Ciências:
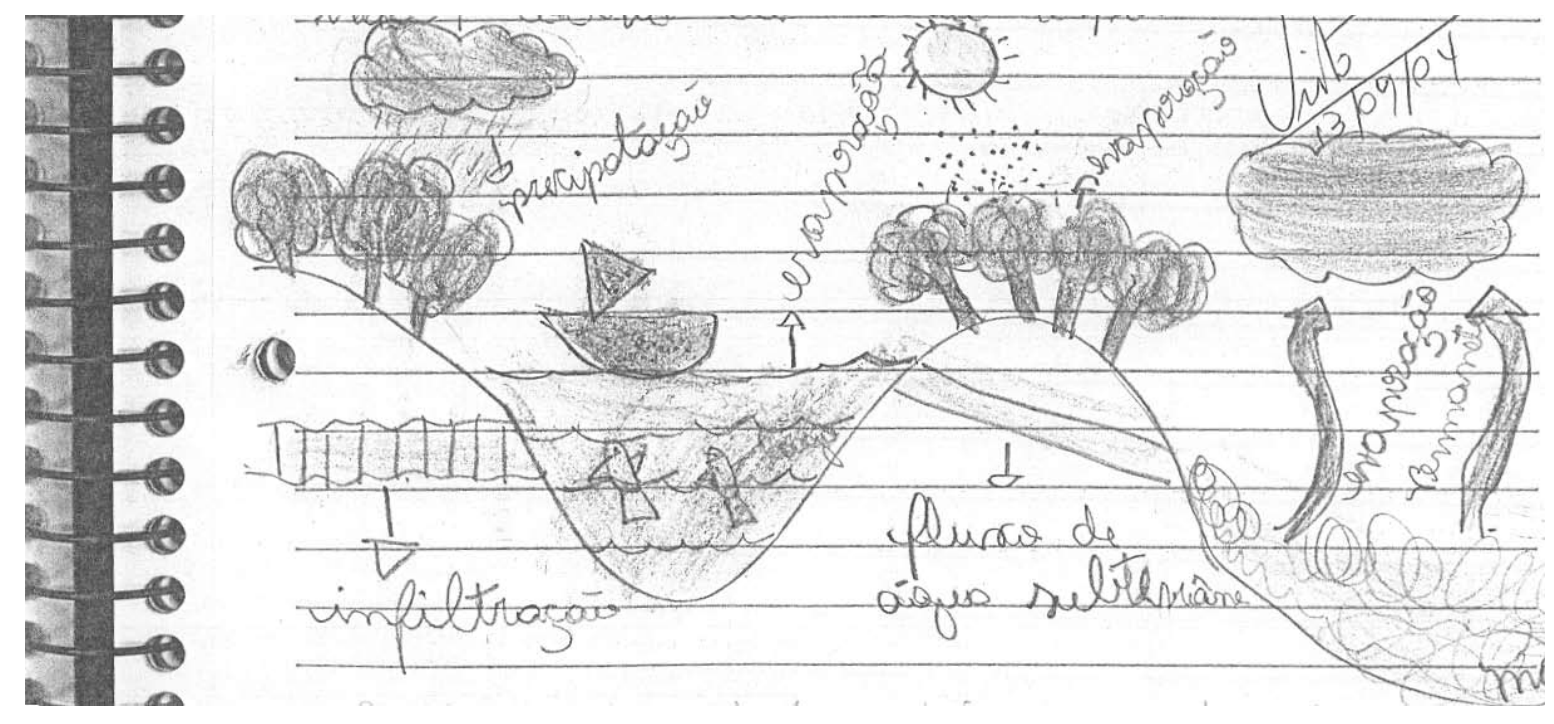

Figura 14. Desenho sobre o ciclo da água encontrado no caderno de Fabiana ${ }^{21}$

À disciplina Geografia foram dedicadas quatro páginas, que continham: uma cópia de texto, o desenho de um gráfico e perguntas relativas ao gráfico. História teve apenas uma página preenchida com enunciados de redações que não foram realizadas pela aluna.

\footnotetext{
${ }^{20}$ Embora analisar o conteúdo dos cadernos não seja o objetivo deste trabalho chama a atenção a solicitação de atividades que desconsidera a condição socioeconômica dos alunos.

${ }^{21}$ Legenda de palavras presentes no desenho, com correções ortográficas (da esquerda para a direita): infiltração, precipitação, evaporação, fluxo de água subterrâneo, evaporação e evaporação permanente.
} 
O caderno de textos era um caderno especial, reservado exclusivamente ao registro de textos produzidos pelos alunos. Silvia foi quem o adotou. Conforme mencionado, foi a própria professora quem comprou os cadernos e os entregou aos alunos, no começo de março. Eram cadernos brochura, pequenos. A intenção de Silvia era tornar mais fácil o transporte para que ela pudesse corrigir os textos e ao mesmo tempo reunir em um único suporte um conjunto de produções dos alunos. Silvia gostava de utilizar esse suporte e fez questão de me mostrar alguns desses cadernos na entrevista.

Quando Malu assumiu a sala de aula, o caderno de textos passou a ser menos utilizado. A professora chegou a manifestar, em final de outubro, não gostar de trabalhar com esse suporte, preferindo as folhinhas:

Malu conta que desistiu de usar aquele caderno de textos: "pra mim aquilo não funciona".

Para Malu, os cadernos de texto não facilitavam a realização das correções. Diferentemente de Silvia, que tinha carro, Malu utilizava-se de transporte público. Por isso, os cadernos de texto acabaram por não ser tão freqüentemente utilizados no segundo semestre. Pude fazer cópias de sete desses cadernos. A maioria tinha pouco mais de 10 páginas utilizadas, apenas o de Cleber apresentou 25 páginas preenchidas. 0 conteúdo era composto basicamente por textos escritos pelos alunos, além de correções e comentários feitas pelas professoras.

Independentemente da disciplina a que pertencia o caderno, outros dois tipos de conteúdos foram registrados: o roteiro do dia e os avisos à família.

0 roteiro do dia era uma lista das atividades que seriam desenvolvidas ao longo do período letivo. Quase diariamente, era registrado antes da primeira atividade realizada no dia. Por essa razão, não houve um padrão na escolha do caderno onde o roteiro seria registrado. A seguir, alguns exemplos de roteiros: 
Roteiro do dia

- Ciências: O ser humano

- Cópia, leitura e estudo do texto: págs 117 até 120.

(Caderno de Ciências de Fabiana, registro feito em 5 de agosto)

Roteiro do dia

- Português

- Vídeo

(Caderno de Português de Fabiana, registro feito em 14 de setembro)

Vários foram os desenhos solicitados pelas professoras. Algumas vezes os desenhos eram parte de uma atividade maior. Ou seja, os desenhos eram utilizados como forma de ilustrar algum tema abordado em sala de aula por meio de outras estratégias, como na última figura apresentada, em que o desenho sobre o ciclo da água vem complementar a cópia de um texto didático sobre o mesmo tema. Outras vezes, o desenho era o essencial da solicitação das professoras, como foi o caso da atividade que Malu me mostrou em agosto:

Malu me mostra vários desenhos feitos pelos alunos. Desenho feito pelos alunos sob o seguinte tema: "O melhor de mim para o melhor dos mundos". A professora me explica que orientou os alunos a mostrarem o que fizeram até agora para construir um mundo melhor.

Os avisos não eram tão freqüentes. Durante minhas observações em sala de aula, pude acompanhar que a professora usava o recurso de escrever um comunicado na lousa e pedir que os alunos o copiassem no caderno para depois mostrar aos pais. Tais avisos se referiam sempre a alguma alteração que fosse ocorrer na escola: a suspensão das aulas, ou o encerramento das atividades em horário diferente do habitual. Nos cadernos de Fabiana, apenas dois foram encontrados. Um deles apresentava o seguinte texto: 
Srs. Pais

Amanhã 04/11/04 não haverá aula para seu filho (a).

Motivo: Capacitação de professores

Profa. Malu 03/11/04

(Caderno de Português de Fabiana, registro feito em 11 de novembro)

As correções, feitas ora pelas professoras, ora pelos próprios alunos também foram freqüentes nos cadernos dos alunos. No entanto, mais de metade das atividades não tinha marcas de correções. Os bilhetes, outro tipo de registro feito pelas professoras, estiveram presentes especialmente nos cadernos dos alunos considerados indisciplinados ${ }^{22}$.

Os castigos também deixaram registros nos cadernos dos alunos. Esse tipo de registro compareceu em quantidades bastante diferentes, dependendo do aluno em questão. Nos cadernos de Fabiana, que foi nossa referência para o levantamento dos registros, não foram identificados castigos. Porém, o fato de uma das professoras utilizar freqüentemente castigos que implicavam escrever algo de cunho moral nos cadernos fez com que esse fosse um tipo de registro recorrente nos cadernos de alguns alunos. Houve castigos que consistiam em realizar cópias. Por exemplo, em uma das aulas de agosto, Malu deu a alguns alunos o castigo de permanecer em sala de aula durante o horário de recreio, fazendo a cópia do conteúdo de um livro. A razão alegada foi que tais alunos tinham incomodado a aula por falarem muito. Ralph, por exemplo, passou o intervalo fazendo a cópia de um livro que defendia o uso da expressão "por favor". Alguns dias antes, o mesmo aluno copiou em seus cadernos 23 vezes a frase: "Não respeito a professora. Ela fala o tempo todo comigo e eu não estou nem aí." ${ }^{23}$ Nos cadernos de alguns alunos, uma redação sobre "A fofoqueira e o fofoqueiro" foi registrada ${ }^{24}$. Foi um castigo imposto pela professora à sala de aula, pois alguns alunos tinham denunciado outros.

\footnotetext{
${ }^{22}$ As correções e os bilhetes foram abordados mais detalhadamente na seção anterior deste capítulo: III.2 Quem registra.

${ }^{23} \mathrm{Na}$ verdade, a frase não foi copiada sempre desse modo. À medida que a frase era repetida, algumas alterações eram feitas em seu conteúdo. Esse episódio será retomado mais adiante na seção III.4.4.2.

${ }^{24}$ No caso de Alex, foi usado o caderno de Matemática. Leonardo, diferentemente, utilizou o caderno de Português. Ambos os textos serão apresentados neste capítulo, na seção III.4.4.1.
} 


\section{III.3.2 CONTEÚDOS REGISTRADOS POR ALUNOS INDEPENDENTEMENTE DE SEREM PROPOSTOS PELAS PROFESSORAS}

Nem somente aquilo que era solicitado pelas professoras e esperado pela escola constituiu o conteúdo dos cadernos dos alunos da quarta série acompanhada. Diversos tipos de registro, feitos por opção dos alunos, podem ser verificados.

Havia alguns alunos, como Fabiana, cujos cadernos eram muito fiéis àquilo que era solicitado pela escola. Em seus cadernos, além das atividades escolares, foi possível encontrar algumas poucas formas mais pessoais de expressão. A mais constante foi a colagem de pequenos adesivos. Assim como outros alunos, Fabiana colava adesivos nas páginas de seus cadernos como enfeite. Em entrevista com ela, conversamos a respeito disso:

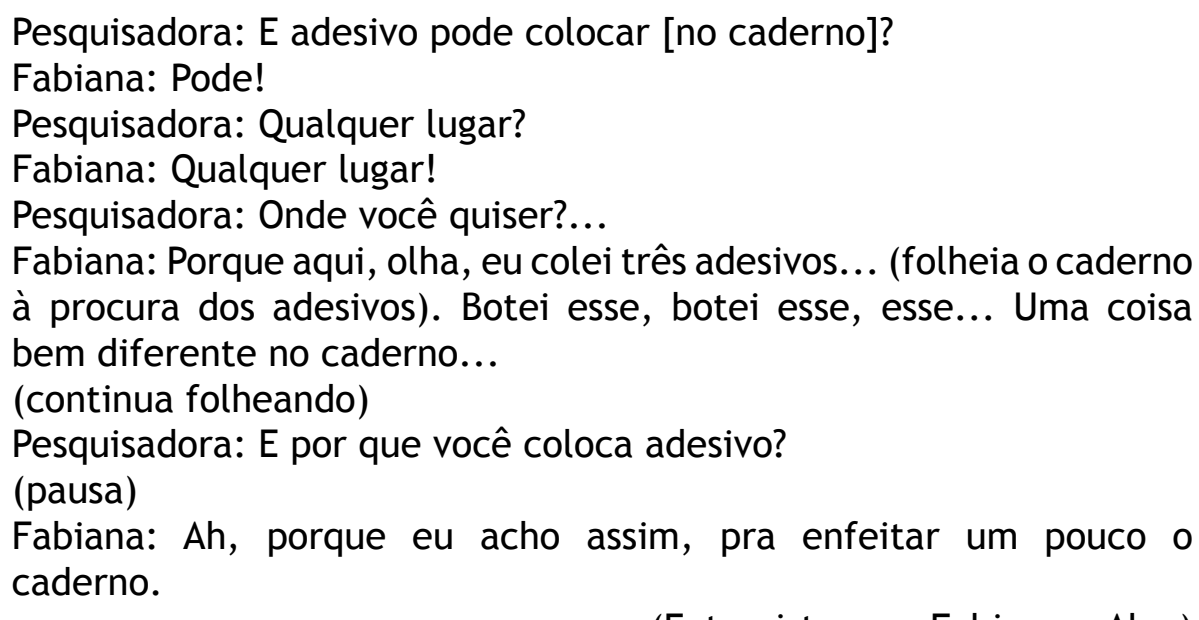

(Entrevista com Fabiana e Alex)

Os adesivos tinham conteúdos variados: propaganda de uma rádio, pontos de interrogação, personagens de desenhos animados, flores, entre outros. Como diz Fabiana, são formas de enfeitar os cadernos permitidas - e por vezes, até bem vistas - pelas professoras. Apesar de a aluna afirmar que podem ser colados em qualquer lugar, seu procedimento sempre foi o de colar os enfeites nos cantos das folhas, deixando livres as linhas para a realização das atividades. Ou seja, ainda que 
intuitivamente, Fabiana sabia como devia proceder para incluir em seus cadernos algo que não foi solicitado pela escola.

Nas margens superiores de uma das páginas do caderno de Português de Fabiana, havia uma declaração de amizade com o seguinte texto: “É Vitória é amiga". Na página seguinte o texto continua: "É a minha amiga". Novamente as margens das folhas foram utilizadas para que a aluna expressasse seus sentimentos. 0 uso dos cadernos para registrar o afeto foi recorrente.

Ronaldo escreve uma declaração de amor no seu caderno (na bolsa plástica que há no início do caderno). Escreve: "Esther meu amor".

Outra forma de expressão bastante comum foi a realização de desenhos não relativos ao conteúdo abordado. Cleber foi um dos alunos que mais expressou seu gosto por fazer desenhos nos cadernos. Na entrevista, fez questão de mostrar suas criações:

Cleber: Olha, esse aqui a professora não tinha falado nada, eu fui lá e desenhei!

(Entrevista com Cleber e Leonardo)

Em seus cadernos, foi possível encontrar diversas bandeiras do Brasil, fantasmas, árvores, estrelas, menino fazendo pichações, entre muitos outros temas. A primeira página de seu caderno de Geografia apresenta uma homenagem ao seu time de futebol: 


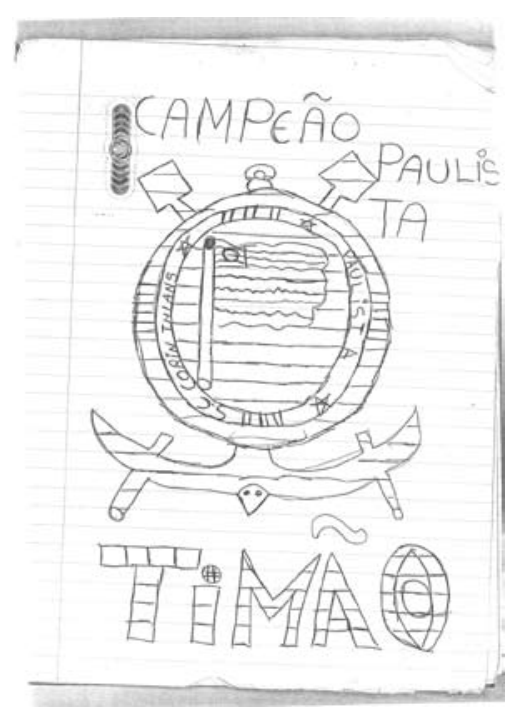

Figura 15. A homenagem de Cleber ao seu time de futebol

Os desenhos dos diversos alunos da quarta série eram sempre dispostos em espaços não necessariamente destinados à escrita, como as margens, a primeira e a última página dos cadernos e, mais raramente, fechando as atividades do dia.

Mas nem sempre os conteúdos dos desenhos eram tão adequados às regras escolares. Ralph reunia em seus cadernos desenhos de tipos variados: heróis de desenhos animados, animais e paisagens. Havia, porém, também outra categoria de desenhos, bastante praticada por Ralph e pouco bem vista na escola: os desenhos de cunho sexual. Desenhos de pênis, nádegas e corpos de mulheres nuas podiam ser encontrados com freqüência nos seus cadernos. Tais desenhos sempre eram dispostos pelo aluno de modo pouco exposto, evitando as repreensões da professora. Assim, ao fazer os desenhos, Ralph dava preferência às páginas anteriormente corrigidas pela professora ou às do fim do caderno.

\section{III.3.3 CONTEÚDOS REGISTRADOS PELOS ALUNOS QUE ESTÃO NA FRONTEIRA ENTRE O PROPOSTO E O NÃO PROPOSTO PELAS PROFESSORAS}

Alguns são os conteúdos que não se enquadram nos propostos pela escola, nem são completamente independentes das atividades escolares. 
Os rascunhos estão nessa fronteira entre aquilo que é proposto e o que não é proposto pela escola. Se, por um lado, são registros que servem de suporte à realização de atividades estritamente escolares; por outro lado, são feitos nos espaços geralmente destinados aos conteúdos não escolares (últimas páginas de cadernos, contracapas e margens), de modo desorganizado - sem respeitar linhas, espalhados nos espaços disponíveis. Alguns alunos se utilizavam com freqüência do procedimento de fazer contas ou ensaiar as diferentes possibilidades de escrita de uma palavra nos cadernos.

Jennifer me contou, em minha primeira visita à sala de aula, que naquele ano tinha optado por não ter agenda, pois preferia anotar o que fosse necessário no próprio caderno. Assim, comecei a identificar outra finalidade que os alunos deram aos cadernos que ficava no limite entre as utilizações propostas e as não propostas: o uso dos cadernos como agenda, ou seja, para registrar compromissos e tarefas futuras:

A vice-diretora entra na sala de aula para perguntar quem são os alunos que estão inscritos para fazer ginástica geral. Alguns alunos levantam as mãos e ela avisa que eles devem estar na escola amanhã às nove horas. Percebo que Alan e Talita anotam o compromisso na contracapa do caderno.

\section{III.4 COMO SE REGISTRA?}

\section{III.4.1 AS REGRAS: SEGUINDO E QUEBRANDO REGRAS...}

Abordar o tema de como eram feitos os registros implica fazer referência às regras, implícitas e explícitas, que regem o ato de registrar. Algumas regras são comuns à realização de registros escolares de modo geral, outras podem ser encontradas na maioria das escolas brasileiras, enquanto algumas são peculiares à sala de aula estudada e ao modo de trabalhar de cada professor. 
Considerando-se o estudo realizado na quarta série do ensino fundamental, os alunos tinham no mínimo quatro anos de vivência do contexto e das regras escolares. Assim, muitas dos preceitos estabelecidos para a realização dos registros eram absolutamente familiares. Os alunos conheciam os conceitos de margem, linha, capa e contracapa e dominavam os procedimentos necessários para a identificação dos cadernos.

Mesmo sem que fossem dadas recomendações pela professora, as regras básicas de manuseio e preenchimento dos cadernos eram seguidas. Um exemplo disso foi observado em minha primeira visita à sala de aula. A professora Silvia entregou cadernos novos aos alunos, os cadernos de textos. Mesmo sem que a professora solicitasse, um aluno colocou uma etiqueta na capa e escreveu seu nome. Outros alunos colocaram nome e telefone na contracapa. Diversos aproveitaram a primeira página e fizeram um desenho. Ou seja, os alunos conheciam bem os procedimentos a adotar para se iniciar um caderno. 0 fato de não haver uma regra rígida regendo esse momento favoreceu que os alunos adotassem formas diferenciadas de proceder.

Além disso, os alunos sabiam que deviam começar a escrever a partir da margem esquerda em direção à margem direita. Utilizavam corretamente a seqüência de linhas, começando pela superior, utilizando as subseqüentes até chegar às últimas de cada página. Conheciam o procedimento de não utilizar algumas linhas para criar uma separação entre atividades, conteúdos ou dias.

Ao longo das aulas, era recorrente as professoras darem indicações de procedimentos que os alunos deveriam adotar: escrever a data, responder, resolver copiar ou não copiar, colar.

Silvia continua dando orientações: "vocês vão pegar a folha [que ela tinha acabado de entregar], colar na primeira página do caderno, colocar a data...."

Não eram necessários, porém, maiores esclarecimentos a respeito de como cada uma dessas ações deveriam ser feitas. Como os alunos conheciam bem o manuseio 
dos diversos suportes de registro, os esclarecimentos dados diziam respeito a como os exercícios deviam ser feitos.

Ainda que a maioria das regras fosse conhecida pelos alunos, não seria possível afirmar que os cadernos revelavam total conformidade em relação àquilo que a escola esperava. Diversas transgressões e formas de utilização diferentes das esperadas pela escola foram encontradas nos registros.

O maneira de os alunos se relacionarem com as regras escolares para a realização de registros é bastante importante para a compreensão de aspectos do cotidiano escolar. Por isso, foi feita a opção de retomar, de modo mais detalhado e descritivo, tal questão no próximo capítulo, dedicado à comparação entre as formas de utilização dos suportes de registro na primeira e quarta série do ensino fundamental.

\section{III.4.2 AS DISCIPLINAS}

A questão da divisão dos conteúdos escolares em disciplinas foi abordada na seção anterior deste capítulo ${ }^{25}$, quando apresentei quais eram os conteúdos escolares presentes nos cadernos. 0 fato de as disciplinas escolares terem facilitado a apresentação dos conteúdos registrados denota o quanto realmente o uso dos cadernos é organizado sob grandes e tradicionais divisões do conhecimento: Português, Matemática, Ciências, História e Geografia. Ainda que tal separação tenha sido encontrada nos cadernos, vale relembrar que nem sempre ela estava presente, tema que também foi abordado com mais detalhes.

No geral, os alunos tinham familiaridade com as regras de dividir os conteúdos em disciplinas. Tal tema não mobilizou grandes explicações ou recomendações, ao longo do ano. Pude acompanhar o início de uma nova disciplina - o Projeto Adolescer - e verificar a facilidade com que os alunos reservavam, cada um ao seu modo, uma parte dos cadernos para ela:

${ }^{25}$ Seção: III.3.1 Conteúdos registrados pelos alunos que foram propostos pelas professoras. 
Valéria pede que os alunos reservem folhas de um caderno para fazer as anotações do Projeto Adolescer. Ressalta que não precisam arrancar as folhas. Jean avisa que vai pôr no fim do caderno. Vejo que os alunos se movimentam para pegar seus cadernos. Igor faz uma dobradura em triângulo e escreve Adolescer. Parece uma marca para abrir a parte do caderno reservada a tal projeto. Jean faz o mesmo.

(RA-17)

Mesmo no início do ano, bastava que a professora indicasse - verbalmente ou por escrito, na lousa - a disciplina referente às atividades para que os alunos iniciassem as atividades:

Silvia introduz mais uma atividade e diz: "vou passar atividade de Matemática, quem terminou copia..."

Os alunos conheciam as subdivisões de seus cadernos e eram capazes de explicar quais eram:

Juvenal me pergunta: "Você tem caderno de português?" Digo que:
"tenho esse (mostrando meu caderno de anotações)". Pergunto a
ele: “e você?" Ele mostra um caderno grande (aproximadamente 400
folhas) e conta que uma parte é Português, outra Matemática, outra
Ciências e outra, ainda, História e Geografia. Pergunto se ele nunca
erra a divisão na hora de fazer as atividades. E ele diz que não. (RA-09)

Apesar de conhecerem as regras, muitas vezes acabavam por fazer as atividades em sequiência, sem trocar de caderno a cada mudança temática. Assim fez Jackson, com o conteúdo do Projeto Adolescer:

Jackson vem falar comigo, me pergunta: "você está copiando?" (provavelmente ele me viu olhando para a lousa). Digo que sim. Pergunto a ele se também copiou e ele diz que sim, só que foi no caderno de português.

Nesse caso, assim como em muitos outros que pude observar, o registro realizado sem obedecer às regras de divisões em disciplinas não se tratava de um engano ou de 
desconhecimento do que deveria ser feito. Era uma opção dos alunos, e em geral não repreendida pelas professoras, de estabelecer separações entre os conteúdos.

\section{III.4.3 CADERNO DE MENINA E CADERNO DE MENINO}

A expressão "caderno de menina", facilmente, sugere um caderno organizado, completo, preenchido com capricho, cuidado e letra bonita. Quando se pensa em cadernos de meninos, esperam-se cadernos pouco organizados, com atividades feitas com desleixo. Tais expectativas, bastante perpetuadas no meio escolar e no senso comum, relacionam-se com os padrões de gênero socialmente construídos e são alimentadas por muitos dos cadernos de meninas e meninos que foram e são produzidos.

Conforme aponta Moreno (1999), a escola é um dos espaços sociais de constituição do feminino e do masculino:

A imagem de mulher e de homem que se passa aos alunos por meio dos conteúdos do ensino contribui intensamente para formar o seu eu social, seus padrões diferenciais de comportamento, o modelo com o qual devem identificar-se para ser "mais mulher" ou "mais homem". (p.36)

Os típicos "cadernos de menina" estariam em conformidade com um padrão de feminilidade assentado na obediência às normas, na organização e na submissão (CARVALHO, 2001). Além disso, seguem uma determinada estética, em que as várias cores de canetas destacam os diversos elementos do conteúdo registrado. Uma das professoras entrevistadas por Carvalho (2001) nomeou de forma interessante os cadernos caracteristicamente femininos, repletos de enfeites: "cadernos cor-derosa". Os relatos de observações estão repletos de descrições de alunas, enfeitando suas produções: 
Jennifer parece ter acabado. Levanta-se faz um coração flechado no canto da folha, pinta.

Selene decora com desenhos as laterais do poema.

Os meninos, diferentemente, dizem com um certo orgulho que seus cadernos não são perfeitos:

Pesquisadora: Seu caderno é esculachado, Cleber?

Cleber: Ah, um pouco eu acho!

Leonardo: Eu acho o meu!

(Entrevista com Leonardo e Cleber)

Assim como Carvalho (2001) descreve em seu relato de pesquisa, encontrei alunos que consideravam que o capricho com o caderno era algo tipicamente feminino:

Pesquisadora: Tem jeito diferente de como menina cuida de caderno e como menino cuida de caderno?

Cleber: Ah, tem. A menina é mais caprichosa.

Leonardo: Tem mais cuidado.

(Entrevista com Leonardo e Cleber)

Assim, não seguir esse padrão aparece como uma das formas de construir uma identidade masculina, mesmo que isso signifique ser menos bem avaliado:

Cleber: Ah, eu não sei, né? Um dos melhores (cadernos) mesmo que eu acho é o das meninas, que nem da Jerusa que ela já é mais caprichosa, a Tainá, Andressa...

(Entrevista com Leonardo e Cleber)

Cleber citou ainda Fabiana, Suzana e Lauriane. Ou seja, quase a totalidade das meninas da sala foi citada para responder à pergunta sobre quem tinha os melhores cadernos da sala. Como exceção, citou Talita: 
Cleber: A Talita parece caderno de moleque. Você já olhou o caderno dela? [...]

Pesquisadora: Olhei um pouquinho.

Cleber: Você viu como é que é? É o mais esculachado! Só que de vez em quando ela faz bem bonito, no capricho.

(Entrevista com Leonardo e Cleber)

Ou seja, mesmo que Talita escrevesse algumas vezes "bem bonito" e "no capricho", o fato de este não ser o seu padrão fez com que Cleber classificasse seu caderno como "caderno de moleque". Cleber apresenta os desleixos presentes nos cadernos de meninos como algo tolerável e até dignos de uma certa dose de orgulho. Para uma menina, no entanto, a falta de capricho é algo condenável.

Assim, como Talita tinha caderno de menino, alguns meninos eram conhecidos por ter cadernos mais bem cuidados. Ainda que não fizessem enfeites, primavam por manter os cadernos organizados. Uelinton e Alex podem ser considerados bons exemplos disso.

Alex foi citado por Leonardo como um dos melhores cadernos da sala:

$\mathrm{P}:$ E quem que tem o melhor caderno da sala?

L: O Alex $[\ldots]$

(Entrevista com Leonardo e Cleber)

O próprio Alex considerou seu caderno organizado em alguns momentos. Ainda que não seja possível estabelecer uma relação com o modo pelo qual Alex fazia os seus registros, vale ressaltar a opinião de Malu a respeito de Alex, manifestada por repetidas vezes:

Malu fala de Alex, comenta que ele é efeminado, "só não vê quem não quer”.

Tanto Silvia quanto Malu declararam não se preocupar tanto com a aparência dos cadernos, privilegiando o aprendizado em vez do registro: 
Não adianta ser organizado, fazer tudo bonitinho no caderno se ele não consegue produzir um texto, se ele não consegue resolver uma operação. Pelo menos uma operação, entendeu? Porque tem aluno que é super organizado, mas depois não consegue fazer nada.

(Entrevista com Malu)

Eu acho que tem que ter sentido aquilo que eles anotam, que eles aprendem. [...] Eu peço que eles tenham um caderno organizado, mas eu não sei se a aprendizagem vem [...] nem só desse caderno, desse registro. Vem de toda a construção que é feita na sala mesmo!

(Entrevista com Silvia)

Ainda que houvesse esse tipo de preocupação, em diversos momentos o estereótipo feminino de realização dos registros predominava na avaliação e nas exigências docentes para com os cadernos de seus alunos:

Silvia dá uma bronca em Juvenal: “Juvenal, seu caderno vai ficar desorganizado? Você lembra o que a gente combinou?"

Juvenal ficou de castigo nesse dia, durante o recreio, para colocar o seu caderno em ordem. Em outros dias, os castigos repetiram-se. Em maio, por exemplo, toda a classe teve de permanecer na sala de aula, pois havia alunos que tinham cadernos desorganizados:

Pergunto a Jordan se o caderno dele é desorganizado e ele diz que sim, Juvenal diz o mesmo. Alex diz que o dele não é. Pergunto, então, por que ele está passando o recreio na sala. Ele conta que é por causa do Guilherme que tem um caderno bastante desorganizado. Eles me dizem que todos os alunos da sala têm que cumprir esse castigo, independentemente de terem seus cadernos organizados ou desorganizados.

(RA-08)

\section{III.4.4 A AUTORIA: CRIANDO E REPETINDO AS FORMAS DE FAZER}

A questão da autoria é central para compreender diversos aspectos relativos ao modo pelo qual os cadernos, bem como os demais registros, são produzidos na escola. 
A importância do tema fez com que a autoria fosse um assunto recorrente nos trabalhos que se propõem a abordar o que é registrado no contexto escolar. Faria (1988) referiu-se a essa questão indicando não encontrar, nos cadernos de primeira série que analisou, canais para que o aluno pudesse se expressar. Ou seja, a autora considerou que os cadernos escolares têm uma possibilidade de autoria bastante restrita. Gvirtz (1999) alega que, mesmo no ato mecânico de reproduzir informações, há possibilidades para a apropriação dessas informações, fato evidenciado pelas pequenas modificações que os alunos fazem e pelas estratégias diferenciadas que utilizam. Apesar de apontar para as possibilidades de autoria existentes, a autora ressalta que, "enquanto a imensa maioria das atividades escolares obedece a uma mão infantil, o estilo de redação corresponde claramente a um adulto" (p.23).

Apesar de ser um tema citado com alguma freqüência, nenhuma das autoras se debruçou mais profundamente sobre a questão da autoria. Algumas perguntas permaneceram sem respostas: a) diante dos limites existentes, quais são as formas de autoria que os alunos encontram para realizar seus registros escolares? b) quem são os autores dos registros escolares?

Cheguei a iniciar uma busca pela resposta a essas perguntas em meu trabalho de mestrado (SANTOS, 2002). Com base nas informações recolhidas em uma sala de primeira série do ensino fundamental, considerei a autoria dos cadernos como múltipla, tendo alunos e professores como os principais autores. Naquele momento, utilizando-me das reflexões teóricas de Foucault (2001) sobre a autoria, as quais afirmam que o autor não é nem o produtor nem o inventor de seus textos, considerei que os modos pelos quais os múltiplos autores preenchiam os cadernos eram expressões das idéias que circulavam, de discursos instaurados. E, por isso, não representavam produções de sujeitos particulares.

Tal maneira de compreender a autoria foi satisfatório para explicar muitos dos conteúdos encontrados na primeira série, momento em que a pouca familiaridade com a escrita impôs limites consideráveis aos alunos. No entanto, novos elementos puderam ser acrescidos com a continuidade da pesquisa. A oportunidade de 
empreender um estudo com alunos da quarta série resultou em informações que apontavam para um nível maior de autoria. 0 conjunto de informações disponíveis suscitou a necessidade de ampliar os referenciais teóricos.

Passarei agora a considerar o conceito de autor com base em uma definição inspirada pelas idéias de Bakhtin e formulada por Faraco (2005):

O autor-criador é [...] quem dá forma ao conteúdo: ele não apenas registra passivamente os eventos da vida (ele não é um estenógrafo desses eventos), mas, a partir de uma certa posição axiológica, recorta-os e reorganiza-os esteticamente. (p.39)

\section{III.4.4.1 A autoria nas produções de texto}

Bakhtin (2003) apresenta algumas reflexões sobre a relação do autor com a palavra que podem auxiliar na compreensão de como a autoria ocorre, ou não ocorre, com os que se iniciam na arte de escrever. Bakhtin, ao descrever o processo de criação, aponta que o autor estabelece uma relação secundária com a palavra. Tal relação seria condicionada à relação com o conteúdo. Assim, a palavra "deve tornar-se expressão do mundo com os outros e expressão da relação do autor com esse mundo" (BAKHTIN, 2003, p. 180).

Durante o processo de alfabetização, a ênfase recai sobre como dar forma escrita às palavras ditas. A utilização das palavras como instrumento para expressar idéias ainda é algo que principia, não sendo muitas vezes suficiente para expressar a relação do autor com o mundo. Assim, as possibilidades de autoria ficam mais restritas. Na quarta série, em vez de alunos que se viam às voltas com os aprendizados básicos das regras escolares, do traçado das letras e das relações entre fonemas e grafemas, passei a acompanhar alunos que, em meio às dificuldades relativas ao uso da língua escrita e a erros de ortografia, ousavam redigir bilhetes e expressar idéias por meio de textos. Familiarizandose com as funções sociais da escrita, em alguns momentos, iam além do que a 
escola solicitava com atividades e tarefas. Igor, por exemplo, me mostrou, em final de setembro, um bilhete que tinha escrito para entregar a uma colega de outra sala. O texto perguntava se a menina queria the dar um beijo e oferecia as alternativas sim e não, para que ela respondesse. Outro momento profícuo de produções escritas foi quando Silvia deixou a sala de aula. A professora me contou a respeito disso na última etapa da entrevista:

Recebi uma cartinha do Ronaldo, dizendo que ele nunca vai me esquecer, que eu fui uma excelente professora, que ele sabe que eu também não vou esquecer ele.

(Entrevista com Silvia)

Como bem mostrou Certau (2005), as possibilidades de usos e práticas, assim como a possibilidade criativa, são multiplicadas quando se domina a linguagem, as práticas e as regras em questão. Ao conhecer a escrita, os alunos usam-na não somente para aquilo que a escola propõe e solicita, mas também para fins próprios. Por vezes, apropriavam-se do que a escola ensinava, ou seja, a escrita, para subverter regras da escola. Vários bilhetes trocados entre os alunos durante as aulas, bem como o bilhete de Igor à sua colega, foram momentos em que pude acompanhar isso.

Mas, afinal, de que modo se revelou a autoria nas produções de texto dos alunos da quarta série?

Certamente, as atividades que mais explicitamente propunham aos alunos o exercício autoral eram as produções de texto, momentos em que, sob um tema, era proposto que os alunos escrevessem. Os níveis de autoria para esse tipo de atividade foram bastante diversos.

É importante considerar que, ao produzirem textos, os alunos relacionam-se de formas diversas com outros textos e discursos que conhecem. Em alguns momentos, tal relação é tão direta que optam por copiar algo que conhecem. Foi o que fez, por exemplo, Sandro. Em resposta à solicitação de fazer uma redação sobre o tema “O planeta pede socorro", apresentou a seguinte produção: 


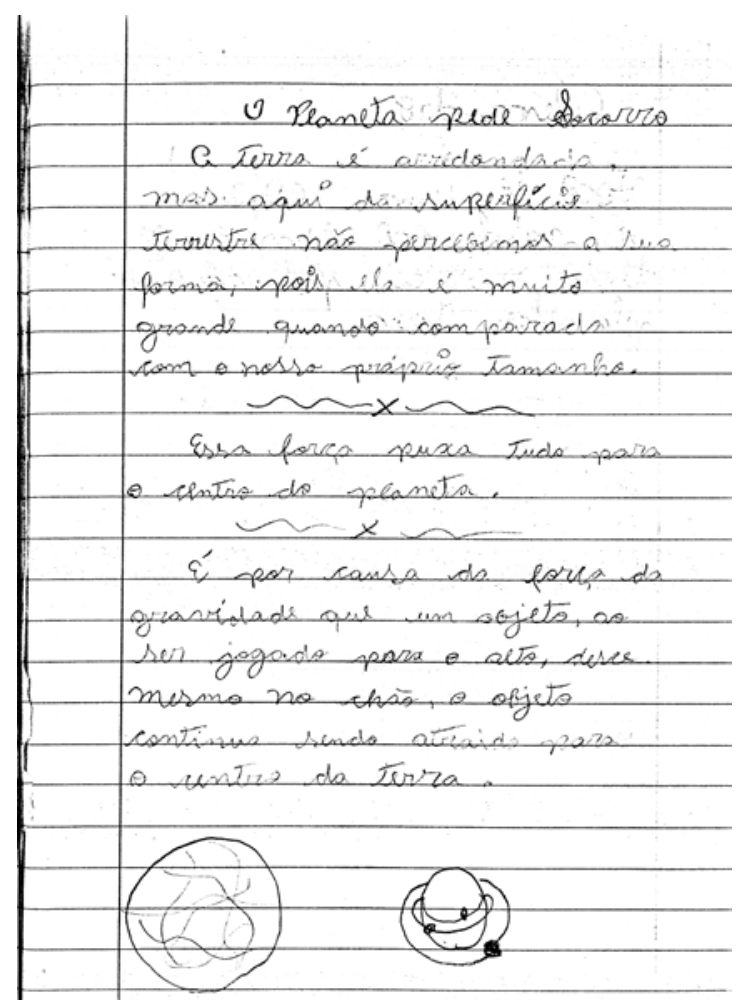

Figura 16. Produção de texto de Sandro com o tema “O planeta pede socorro"26

Tratava-se da cópia de trechos de um livro didático, devidamente escolhidos pelo aluno. Mais do que apenas reproduzir o conteúdo do livro, Sandro reorganizouo. Mas sua produção foi repreendida por escrito pela professora:

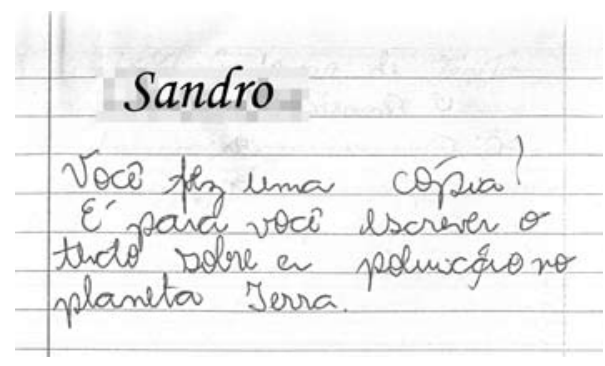

Figura 17. Bilhete da professora para Sandro

26 Conteúdo do texto de Sandro:

O Planeta pede Socorro

A terra é arredondada. Mas aqui da superfície terrestre não percebemos a sua forma, pois ela é muito grande quando comparada com o nosso próprio tamanho.

Essa força puxa tudo para o centro do planeta.

É por causa da força da gravidade que um objeto, ao ser jogado para o alto, desce. Mesmo no chão, o objeto continua sendo atraído para o centro da terra. 
O tema dos trechos copiados manteve apenas uma correspondência parcial com o assunto solicitado. Em vez de abordar a questão da poluição, Sandro escolheu um texto que abordava características do planeta. A cópia não foi aceita pela professora. Ao solicitar atividades de produção de textos, era previsto que o próprio aluno organizasse e apresentasse idéias, não bastando escolher um texto e reproduzi-lo.

Vejamos agora uma produção sobre o mesmo tema, elaborada por Jennifer e bem avaliada pela professora:

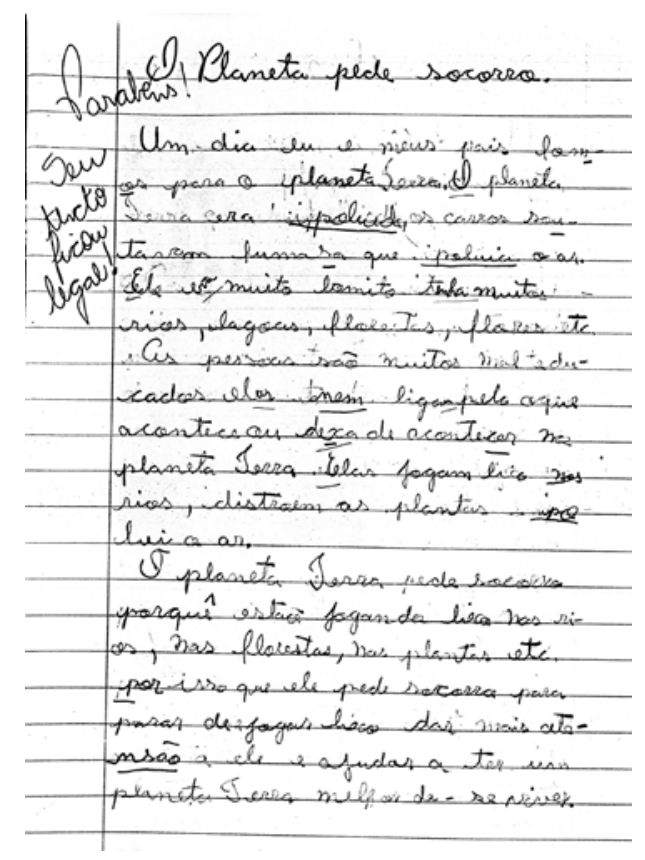

Figura 18. Produção de texto de Jennifer com o tema "O planeta pede socorro"27

É um texto que traz idéias e discursos recorrentes, tais como: a poluição no planeta, o descaso e a falta de educação daqueles que jogam lixo de modo inadequado, o apelo para que se cuide melhor do planeta. Tanto nos escritos de Jennifer como nos demais textos

27 Conteúdo do texto escrito por Jennifer, com correções ortográficas:

O Planeta pede socorro

Um dia eu e meus pais fomos para o planeta Terra. O planeta Terra era poluído, os carros soltavam fumaça que poluía o ar. Ele era muito bonito tinha muitos rios, lagoas, florestas, flores etc. As pessoas são muitos mal educados elas nem ligam pelo o que acontece ou deixa de acontecer no planeta Terra. Elas jogam lixo nos rios, destroem as plantas polui o ar. 0 planeta Terra pede socorro porque estão jogando lixo nos rios, nas florestas, nas plantas etc. Por isso que ele pede socorro para parar de jogar lixo dar mais atenção a ele e ajudar a ter um planeta Terra melhor de se viver.

Correção da professora: Parabéns! Seu texto ficou legal! 
produzidos pelos alunos, comparecem diversos outros textos. Ou seja, os alunos apropriamse de outros discursos que circulam na escola, na família, na mídia e nos demais contextos a que têm acesso e os reorganizam de modo singular. Como diz Bakhtin (1992):

Eu vivo em um mundo de palavras do outro. E toda a minha vida é uma orientação nesse mundo; é reação às palavras do outro (uma reação infinitamente diversificada). (p.379)

As fronteiras entre as próprias palavras e as palavras do outro não são claras, confundem-se com freqüência. É possível reconhecer nos textos produzidos pelos alunos o processo em que interpretam as palavras alheias e as tornam "minhasalheias". Esse é um estágio para que se tornem efetivamente palavras pessoais, ou seja, sem as aspas (GERALDI, 2003). O texto abaixo ilustra esse fenômeno:

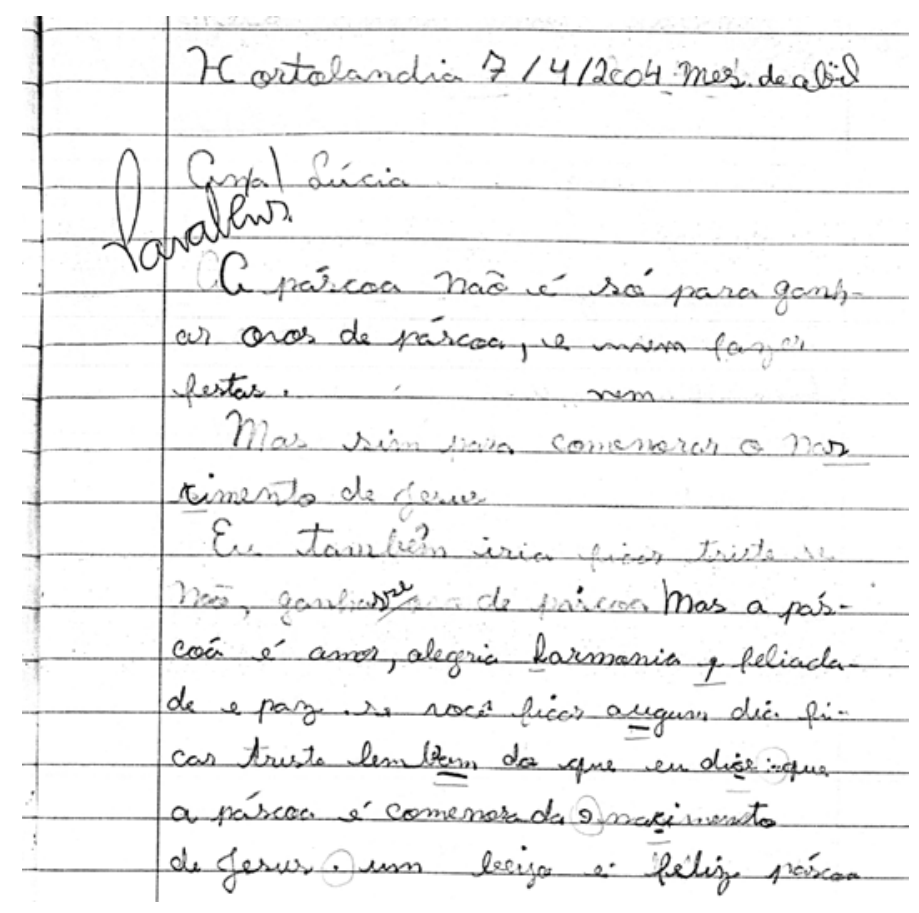

Figura 19. Produção de texto de Jennifer com o tema "Páscoa"28

${ }^{28}$ Conteúdo do texto de Jennifer sobre a Páscoa, com correções ortográficas: Hortolândia 7/4/2004

Ana Lúcia

A páscoa não é só para ganhar ovos de páscoa, e nem fazer festas. Mas sim para comemorar o nascimento de Jesus Eu também iria ficar triste se não ganhasse ovo de páscoa. Mas a páscoa é amor, alegria, harmonia, felicidade e paz. Se você ficar algum dia ficar triste lembre do que eu disse: - que a páscoa é comemorada o nascimento de Jesus. Um beijo e feliz páscoa. 
Jennifer escreve uma carta sobre os diversos significados da Páscoa: ganhar ovos, festa, nascimento de Jesus, amor, alegria, harmonia, felicidade e paz. Alguns significados são apresentados como os mais conhecidos: ganhar ovos e fazer festa. Mas, além destes, apresenta o significado recém-aprendido - comemorar o nascimento de Jesus -, buscando valorizá-lo. Chega a sugerir à destinatária da carta que se alegre ao lembrar que na Páscoa se comemora o nascimento de Jesus. A autora, por sua vez, diz que não ganhar um ovo de Páscoa seria motivo para ficar triste. As diversas significações relativas à Páscoa, oriundas de textos distintos, são entremeadas e apresentadas na produção de Jennifer. As significações aceitas socialmente aparecem lado a lado com as conhecidas e aceitas pela autora, construindo um texto que colige diferentes discursos.

Bakhtin (1992) descreve a autoria como um posicionamento axiológico diante dos eventos da vida. Assim, a criação envolve diversas operações, posicionamentos e uma reorganização diante do que foi vivido. 0 autor organiza um novo mundo por meio de um viés valorativo, ou seja, não transpõe o mundo da vida para a escrita, mas reorganiza-o sob uma nova unidade. O texto de Alex, escrito para cumprir um castigo, ilustra as possibilidades de posicionamentos encontradas pelos alunos de quarta série: 

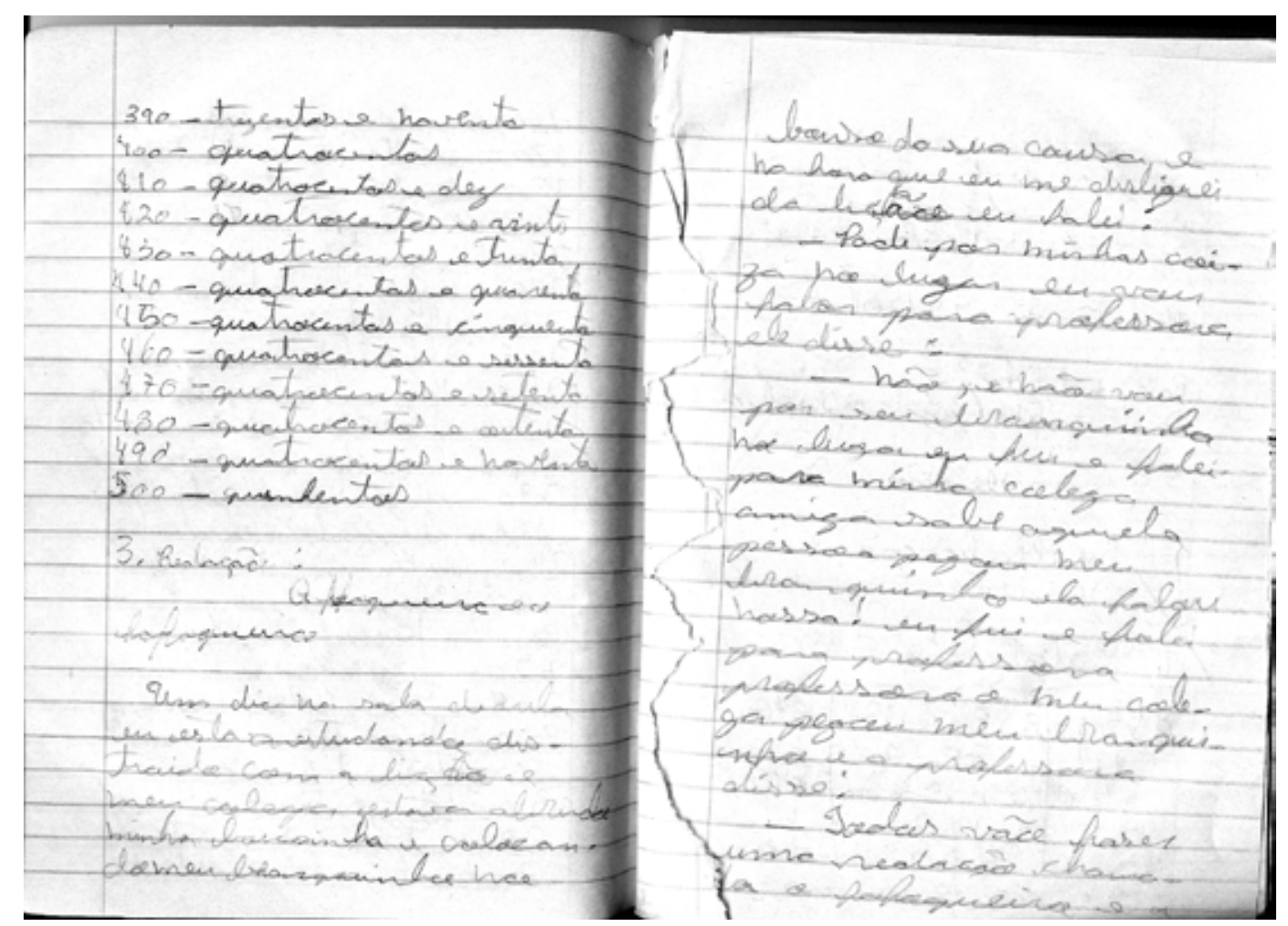

Figura 20. Redação de Alex, com o tema “A fofoqueira e o fofoqueiro"29

A redação "A fofoqueira e o fofoqueiro" foi solicitada pela professora a seus alunos como um castigo. Ao reprovar a atitude de alguns alunos, a professora infligiu que escrevessem sobre o tema da fofoca. Alex compreendeu a repreensão, mas utilizou a punição para relatar a situação que o fez denunciar algo à professora - o colega pegou o seu corretivo líquido e recusou-se a devolvê-lo. Em vez de se redimir pela “fofoca”, cumpriu o castigo, mas manteve a defesa da atitude tomada.

${ }^{29}$ Conteúdo da redação de Alex, com a estrutura de texto mantida. Foram feitas apenas correções ortográficas:

A fofoqueira e o fofoqueiro

Um dia na sala de aula eu estava estudando distraído com a lição e meu colega estava abrindo minha bolsinha e colocando meu branquinho no bolso de sua calça e na hora que eu me desliguei da lição eu falei:

- Pode pôr minhas coisas no lugar eu vou falar para a professora.

Ele disse:

- Não, eu não vou pôr seu branquinho no lugar. Eu fui e falei para minha colega amiga sabe aquela pessoa pegou meu branquinho ela falou

Nossa! Eu fui e falei para a professora

Professora o meu colega pegou meu branquinho e a professora disse:

- Todos vão fazer uma redação chamada o fofoqueiro e a fofoqueira por isso eu fiz essa redação escrevendo o que aconteceu. 
Ao ler as produções dos alunos, é possível perceber algo que transcende a relação com o próprio texto, trata-se de uma relação com as informações que circulam no mundo e que são gradativamente apropriadas pelas crianças. As produções escritas evidenciam as formas pelas quais as crianças passam a participar da textura de comunicação humana. (SMOLKA, GOES e PINO, 1998). São formas de relação intersubjetiva materializadas, de modos diversos, na produção dos registros escolares. Ao criarem textos, os alunos estabelecem todo o tempo relações com os outros e com o que conhecem do mundo. Relacionam-se com o suposto leitor - quase sempre a professora e apenas em algumas situações os colegas ou os pais -, relacionam-se com as alteridades presentes nos diversos discursos que conhecem. Considerando-se a importância das relações intersubjetivas para o desenvolvimento e para a formação da consciência (VIGOTSKI, 1989; BAKHTIN, 1992), os textos produzidos na escola têm, em alguns momentos, o potencial de participar dos processos de constituição dos sujeitos. São atividades que favorecem a utilização da língua escrita como instrumento de comunicação de idéias e fatos, exigindo uma organização do pensamento não utilizada corriqueiramente, a fim de que aquilo que pretendem dizer possa ser compreendido pelo leitor.

Cabe ressaltar que nem todas as atividades de produção de textos propostas pela escola são efetivamente ocasiões em que os alunos exercem sua potencialidade autoral. A disposição ou não para que os alunos se envolvam com a escrita de textos passa pela significação dos objetos sobre os quais a atividade é proposta. A fim de exemplificar, tomarei as produções de Leonardo.

Leonardo, um dos alunos entrevistados na pesquisa, era um dos poucos alunos negros da escola. Não era um dos melhores alunos, mas apresentava um bom rendimento escolar. De modo geral, cumpria as atividades propostas, deixando de fazer alguns dos trabalhos. Tinha cadernos razoavelmente completos, apesar de não primar por enfeitá-los. Estava sempre com um grupo de colegas de sala de aula. Cleber era a companhia mais constante. Comumente, Leonardo era repreendido de modo ameno pela professora, ora por conversar, ora por fazer algo considerado indisciplinado. 
Tive acesso a cadernos e folhinhas de Leonardo que abrangiam o período de março a novembro, ou seja, quase a totalidade do ano letivo. Pude encontrar apenas três produções de texto. A primeira, no caderno de Português, era referente ao mês de agosto:

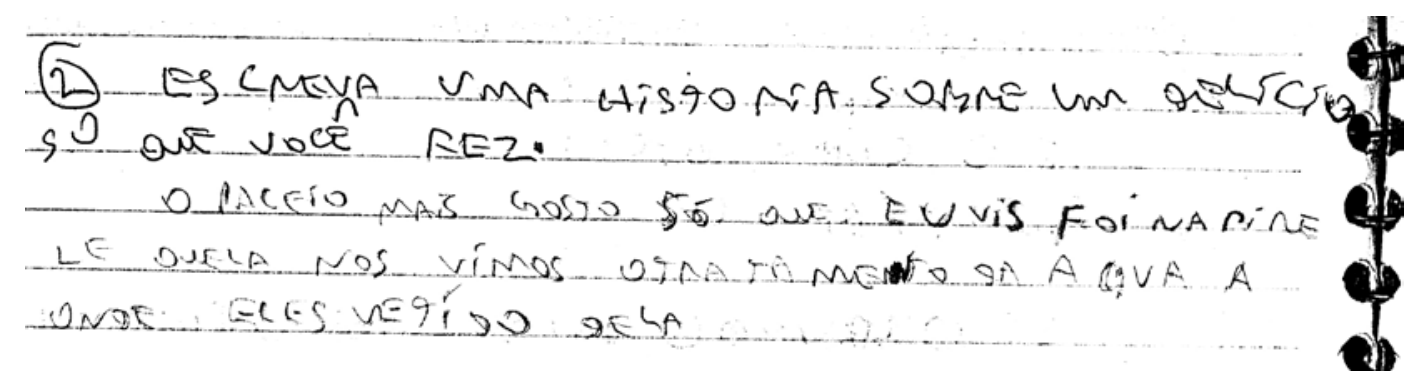

Figura 21. Produção de texto de Leonardo com o tema "Passeio delicioso" 30

A segunda data de outubro, também no caderno de Português, e foi feita como cumprimento do castigo imposto à sala. Tal produção tinha como tema "A fofoqueira e o fofoqueiro":

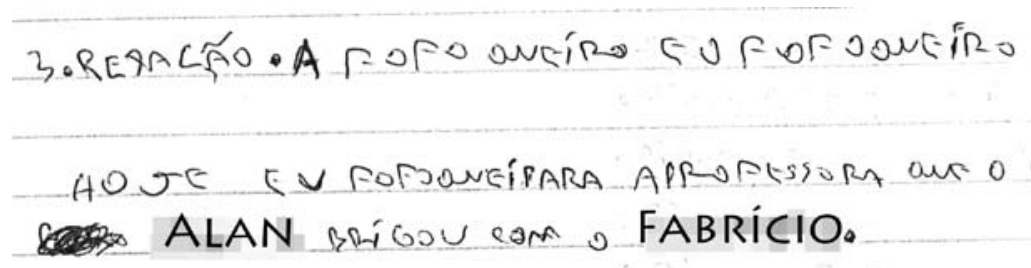

Figura 22. Produção de texto encontrada no caderno de Leonardo com o tema "A fofoqueira e o fofoqueiro" 31

Nos dois meses que separam esses dois trabalhos, é possível verificar um progresso no domínio da escrita. Ambas as produções, porém, têm em comum serem compostas por textos curtos, que apresentam e articulam uma pequena quantidade

\footnotetext{
${ }^{30}$ Conteúdo do texto com correções ortográficas:

O PASSEIO MAIS GOSTOSO QUE EU FIZ FOI NA PIRELLI QUE LÁ NÓS VIMOS O TRATAMENTO DA ÁGUA A ONDE ELES (TIRAM OS VESTÍGIOS?) DELA.

31 Conteúdo do texto:

A FOFOQUEIRA E O FOFOQUEIRO

HOJE EU FOFOQUEI PARA A PROFESSORA QUE O ALAN BRIGOU COM O FABRÍCIO.
} 
de informações, algo que contrasta com o texto produzido em novembro sob o tema "O que é discriminação":

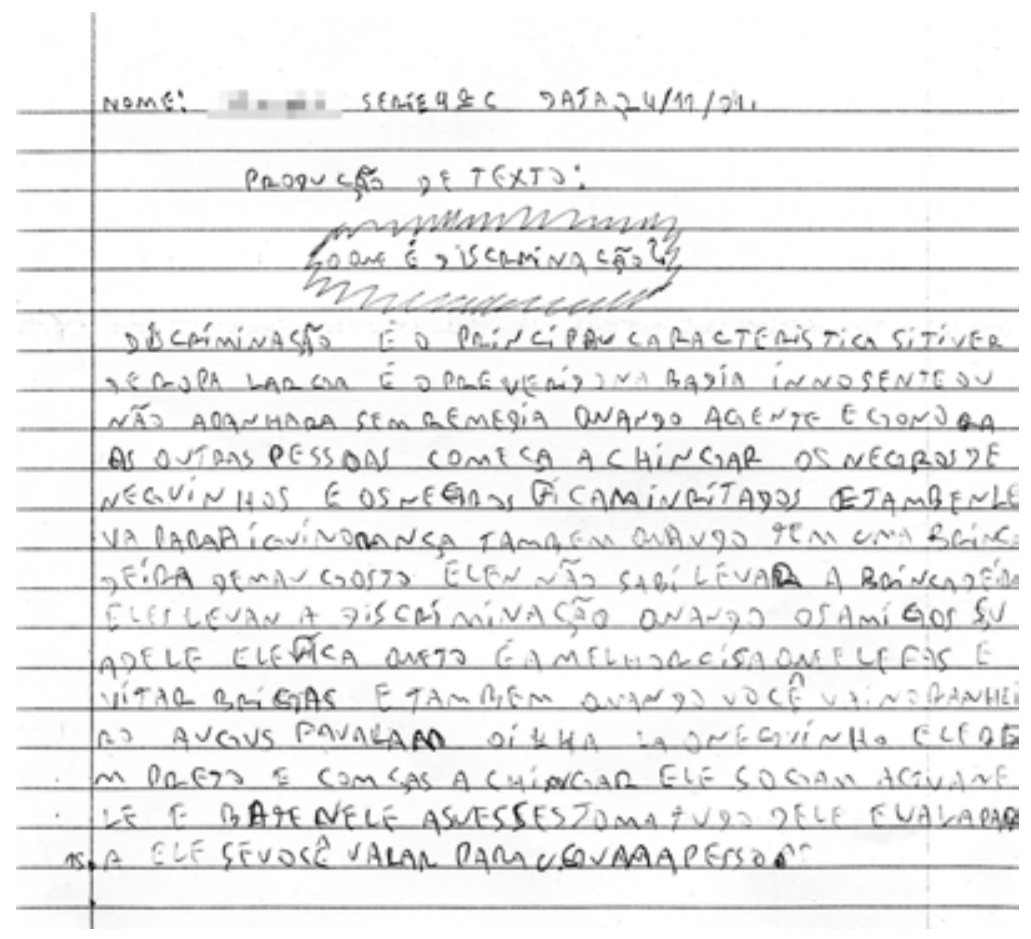

Figura 23. Produção de texto de Leonardo com o tema "O que é discriminação?" 32

32 Reprodução do conteúdo do texto:

NOME: LEONARDO SERIE $4^{\mathrm{a} C} \mathrm{C}$ DATA $24 / 11 / 04$

PRODUÇÃO DE TEXTO:

O QUE É DISCRIMINAÇÃO

DISCRIMINAÇÃO É O PRINCIPAL CARACTERÍSTICA SI TIVER DE ROPA LARGA É O PREVERIDO NA BADIA INNOSENTE OU NÃO APANHARA SEM REMEDIA QUANDO A GENTE EGONORA AS OUTRAS PESSOAS COMEÇA A CHINGAR OS NEGROS DE NEGUINHOS E OS NEGROS FICAM INRITADOS E TAMBÉN LEVA PARA A IGUINORANÇA TAMBEM QUANDO TEM UMA BRINCADEIRA DE MAU GOSTO ELES NÃO SABI LEVAR A BRINCADEIRA ELES LEVA NA DISCRIMINAÇÃO QUANDO OS AMIGOS ZUA DELE ELE FICA QUETO É A MELHOR CISA QUE ELE FAZ EVITAR BRIGAS E TAMBEM QUANDO VOCÊ VAI NO BANHEIRO AUGUS FAVALAM OILHA LA O NEGUINHO ELE DEM PRETO E COMÇAS A CHINGAR ELE JOGAM AGUA NELE E BATE NELE AS VESSES TOMA TUDO DELE E VALA PARA ELE SE VOCÊ VALAR PARA UGUMA PESSOA

Conteúdo do texto com correções ortográficas e gramaticais, com acréscimos baseados na leitura que Leonardo fez do próprio texto em entrevista:

Discriminação é a principal característica. Se estiver de roupa larga é o preferido na batida. (Igual assim, o policial vê um moreno escuro, roupa larga assim, aí já vai e começa a bater nele.) Inocente ou não, apanhará sem remédio. Quando a gente ignora, as outras pessoas começam a xingar os negros de neguinhos, e os negros ficam irritados e também levam para a ignorância. Também quando tem uma brincadeira de mau gosto, eles não sabem levar a brincadeira, eles levam a discriminação. Quando os amigos zoam dele, ele fica quieto, é a melhor coisa que ele faz, evitar brigas. E também quando você vai no banheiro, alguns falavam: "olha lá o neguinho." Ele [?] preto e começa a xingar. Eles jogam água nele e batem nele, às vezes tomam tudo dele, e falam para ele: "Se você falar para alguma pessoa (aí eles vão continuar batendo mais ainda)." 
Primeiramente, a produção sobre discriminação chama a atenção pela extensão. Em vez das costumeiras duas linhas, temos 14 linhas de texto. Além de ser longo para os padrões de Leonardo, é um texto que reúne diversos aspectos do tema proposto. Primeiramente aborda a situação de uma batida - supostamente policial - na qual não será a inocência ou a culpa que determinará o tratamento que a pessoa sofrerá, mas sim a vestimenta utilizada. A seguir, passa a ser abordada a questão racial. 0 modo pelo qual os negros são chamados, as brincadeiras de mau gosto, as agressões verbais e físicas que sofrem. Vários tipos de possíveis reações são apresentados: ficar irritado, “levar para a ignorância”, ficar quieto para evitar brigas.

Por ocasião da entrevista, da qual participaram Leonardo e Cleber, a redação foi comentada e lida. Com uma certa dose de timidez, Leonardo permitiu que o colega conduzisse a leitura. Cleber lia e a cada dificuldade de compreensão Leonardo assumia a tarefa, acrescentando alguns elementos, comentando e trazendo exemplos do que havia escrito. Foi nessa ocasião em que contou, por exemplo, uma situação ocorrida com seu tio:

A gente estava lá na frente da casa dele assim, daí a gente estava conversando, aí os policiais chegaram, desceram, e começaram a bater nele!

(Entrevista com Cleber e Leonardo)

Também durante minhas observações em sala de aula, pude presenciar situações bastante próximas às que Leonardo cita. Cleber, seu grande amigo, fazia piadas com o fato de Leonardo ser negro:

Cleber fala: “Ontem eu vi a família do Lelê pendurado tudo ali, um monte de urubu."

O envolvimento de Leonardo com o texto ficou evidente em diversos momentos. Além das estreitas relações entre suas vivências e o conteúdo escrito e do entusiasmo 
nos comentários, chamou a atenção o como 'lia’ sua produção. As últimas palavras escritas por ele diziam, de forma inconclusa: "se você falar para alguma pessoa". Ao realizar a leitura, Leonardo completa a frase, sem fazer interrupções no fluxo da fala, ou seja, completa o texto como se o lesse:

Leonardo: Se vo...

Cleber: Se você falar...

Leonardo: Pra alguém, alguma pessoa. Se você falar pra alguma pessoa, aí eles vão continuar batendo mais ainda.

(Entrevista com Cleber e Leonardo)

A produção de Leonardo sobre a discriminação é repleta de significados pessoais. Negro e pobre, Leonardo reconheceu em sua vida elementos diversos que embasaram a construção de um texto que resulta de um posicionamento axiológico diante do mundo. Ele mostra, do seu ponto de vista, o que viveu e conheceu. Descreve, comunica, interpreta, reorganiza, atribui sentimentos.

A diversidade das produções escritas de Leonardo ilustra o que ocorria, com freqüência, na sala de aula estudada. Alguns temas eram repletos de significação pessoal para alguns alunos que os tomaram com dedicação; outros temas foram abordados apenas para cumprir uma tarefa, ou até mesmo eram ignorados. Ocorreram desempenhos bastante diversificados de um mesmo aluno em diferentes temas, assim como diferenças bastante significativas entre alunos que trabalhavam a mesma proposta.

Além da solicitação de produções individuais, era recorrente o procedimento de construção coletiva de textos na sala de aula. Tal modalidade de texto sempre foi antecedida por uma atividade preparatória, na qual os alunos redigiam textos individuais sobre o tema. Posteriormente, dois diferentes tipos de produções eram propostas: um dos textos produzidos era corrigido coletivamente, dando origem a uma nova produção, ou a sala de aula produzia um texto único, reunindo as idéias presentes nos vários textos. Para exemplificar como se dava essa construção coletiva, tomarei uma atividade cujo tema foi "A higiene no nosso bairro", realizada em 16 de abril.

A professora Silvia iniciou a atividade, explicando como procederia: 
Agora eu vou ler os textos que vocês fizeram sobre o bairro de vocês. Depois a gente vai fazer um texto só.

Passou, então, a ler os textos individuais. Em sua maioria, eram textos curtos ilustrados com desenhos. Várias características do bairro foram apontadas: a falta de esgoto, a falta de segurança, a falta de serviço de recolhimento de lixo, a presença do lixão, os buracos nas ruas, a falta de transporte público.

Os procedimentos adotados pelos moradores da região em relação ao lixo geraram discussões. Vários alunos reclamaram dizendo que as pessoas jogam o lixo em qualquer lugar, até mesmo na casa dos vizinhos. Lembram as conseqüências dessa forma de proceder: o lixo é levado pelas enxurradas, ou espalhado pelos cães que vivem no bairro, causando riscos à saúde das pessoas. Um texto dizia que o bairro era limpo, mas em razão da ação de moradores que se encarregavam de cuidar da rua. Gianny contou que costumava jogar o lixo no "buracão"33, afirmação que causou desagrado na sala de aula. Diversos alunos vaiaram e reclamaram ao ouvir a declaração do colega. Gianny, que fez a afirmação de forma bastante convicta, pareceu não entender a razão para tal reação. A professora, que desconhecia a existência desses “buracões”, também não compreendeu a reação da sala:

Silvia pede que falem do lixão, contem onde é. Vários alunos querem dizer onde é o lixão. Gustavo explica que é perto do presídio (que fica a alguns quilômetros da escola). Aos poucos, é possível perceber que Silvia não quer saber do lixão, mas dos buracões onde as pessoas depositam o lixo. Silvia pergunta a Gianny: "é lá [no lixão] que você joga o lixo?". A partir dessa pergunta, as crianças percebem a confusão da professora e explicam que não é no lixão que as pessoas colocam o lixo, mas nos buracões.

Diante dessa informação, Silvia também recrimina o ato de Gianny.

Alguns alunos escreveram sobre como gostariam que o bairro fosse. Falam que gostariam que cada um fizesse sua parte para manter o bairro limpo. Ralph diz que gostaria

${ }^{33}$ A região caracterizava-se por ter grandes depressões não ocupadas por habitações, utilizadas, com freqüência, para o depósito de entulho e lixo doméstico. 
que houvesse limpeza, plantações e ajuda aos paralíticos. Foram poucos os comentários que trouxeram aspectos positivos do bairro: um aluno comentou que o bairro onde mora é limpo e bonito, e Fabrício apontou que o bairro é simples, mas é onde ele pode brincar. Após ler todos os textos individuais, Silvia perguntou aos alunos se gostavam do bairro onde moravam. A maioria dos alunos responde que sim. E, então, Silvia sintetiza o conteúdo dos textos: "Todo mundo gosta de morar no bairro, mas o bairro precisa de melhorias" (RA-05). A síntese parece agradar a quase todos os alunos, mas Ralph discorda, dizendo que mora em frente de duas "bocas" ${ }^{44}$ e que não se pode gostar de um bairro assim.

A seguir, Silvia iniciou a escrita propriamente dita do texto coletivo: "Agora vocês não vão copiar, vão me ajudar a escrever. Depois vocês vão copiar” (RA-05). Pede que eles digam o primeiro parágrafo:

Jackson diz: "o nosso bairro não pode ser sujo." Silvia não fica muito contente com a sugestão e pede que eles contem primeiro como é o bairro para depois dizer como não pode ser. Silvia quer que eles digam que gostam de morar no bairro. E a primeira frase é conseguida: "Nosso bairro é um lugar que gostamos de morar".

Silvia quer que eles digam se é melhor a palavra que ou onde Ela parece sugerir o onde. A sala opina, mas há uma divisão de opiniões. Há uma espécie de votação, os alunos dizem qual preferem. A maioria sugere o que e Silvia acaba desistindo.

Prosseguindo no texto, Silvia quer que eles digam porque gostam de morar lá. Alguns alunos dizem que é porque o bairro é bonito, tranqüilo. Nesse ponto, Silvia pergunta: “tem violência?”. Ela diz algo sobre não ser possível dizer que um lugar é ao mesmo tempo tranqüilo e que tem violência. Ronaldo diz que é um lugar onde gostamos de morar porque moramos há anos.

Silvia parece querer retomar os conteúdos de que eles gostam e faz uma pergunta (que acaba direcionando decisivamente o conteúdo da frase que foi colocada.). Silvia pergunta se eles brincam na rua. Muitos dizem que sim. Aí ela pergunta quais são as brincadeiras. A partir das respostas, continua a frase que fica assim: "Nosso bairro é um lugar que gostamos de morar porque dá para jogarmos burquinha, brincarmos de pega-pega, amarelinha, esconde-esconde e muitas outras brincadeiras".

Alguns alunos participam ativamente (Jackson, Ralph, Gianny...). Regina e Talita são alunas que copiam muito caladas.

34 Pontos de venda de drogas. 
Para escrever o segundo parágrafo, a negociação continua:

Para o segundo parágrafo, Silvia pede que eles contem como é a higiene do bairro. Ela fala do lixo a céu aberto, do lixão, mas tenta incluir outros elementos. Diz que eles falaram que há lugares mais organizados. Os alunos continuam falando de sujeiras: bairro feio, imundo, as ações das pessoas contribuindo para o mau cheiro. [...]

Ralph dá uma sugestão para solucionar o problema do lixo, Igor diz que "não deve jogar lixo". Silvia pede que eles contem primeiro como o bairro é, depois falarão das soluções. [...]

Silvia não quer começar de novo com 'nosso bairro'. Pergunta como pode começar. Ralph diz "com quebrada"35". Silvia não considera a sugestão ou realmente não ouviu o que ele disse. Alex sugere: 'onde nós moramos'. A sugestão é aceita.

Silvia continua fazendo perguntas que sugerem conteúdos: “os problemas aqui do bairro são sérios ou fáceis de resolver?” [...] Comenta que nesse tipo de texto não é bom ter rimas. Dois alunos estavam querendo rimar.

Para o terceiro parágrafo, o processo se repetiu. Silvia sugeria temas, os alunos traziam elementos, arriscavam frases. Algo era escrito na lousa, passava por uma avaliação da professora e dos alunos. Alguns ajustes eram decididos. Nem sempre a professora ficava satisfeita, assim como nem sempre todos os alunos se sentiam representados pelo conteúdo escolhido para compor o texto.

Apenas para o último parágrafo o procedimento foi diferente. Walkíria escreveu sozinha, em seu caderno, uma frase. Apresentou à professora, que leu em voz alta para a sala. Alguns alunos desaprovam o fato de a frase começar por "nosso bairro", mas por fim a sala acatou a sugestão da colega na íntegra. O texto coletivo, copiado pelos alunos, ficou da seguinte forma:

$\overline{35}$ Gíria para bairro. 
Texto coletivo: A higiene no nosso bairro

Nosso bairro é um lugar que gostamos de morar porque dá para jogarmos burquinha, brincarmos de pega-pega, amarelinha, escondeesconde e muitas outras brincadeiras.

Onde nós moramos não é perfeito, como qualquer outro lugar. Nós vivemos com falta de higiene. Não temos rede de esgoto, algumas ruas não são asfaltadas e tem muito lixo jogado.

Aqui no bairro nós temos vários buracões onde as pessoas jogam todo tipo de lixo, causando mal (sic) cheiro e o aumento de muitos insetos.

Nosso bairro precisa de higiene e isso depende de cada um. É só não jogarmos lixo nas ruas e nas calçadas, colocar lixos em sacos para ser coletados. Assim estaremos contribuindo com a limpeza de nosso bairro.

É possível encontrar no texto final muitos dos assuntos abordados ao longo da construção do texto. Alguns elementos, tais como as brincadeiras, surgem apenas no texto coletivo. As sugestões da professora guiaram fortemente a estrutura do texto, mas os alunos foram dando forma e conteúdo ao que lhes era solicitado. Certamente, a elaboração final não foi absolutamente de todos os alunos. Mas, a seu modo cada um contribuiu. A leitura inicial dos textos individuais abrangeu toda a sala. E até mesmo Walkíria, que não costuma se manifestar verbalmente, encontrou uma forma alternativa de colaborar. Temos, portanto, uma autoria coletiva. Ainda que alguns trechos possam ser atribuídos a este ou àquele aluno, no geral não é possível atribuir autorias individuais, dado que as idéias foram amplamente discutidas, reformuladas e ajustadas pelo conjunto da sala de aula.

Todo o processo de construção do texto traz uma importante questão relativa aos registros: o que escapa, o que não é passível de registro, o que não pode ser recuperado por meio de uma produção documentada. Assim como o texto final não permite reconhecer autorias individuais, também não permite identificar os bastidores que possibilitaram a formulação das cerca de 15 ou 20 linhas produzidas, registradas nos cadernos como uma cópia. Diversos processos subjacentes à produção do texto não comparecem nos documentos, tais como: a possibilidade de que a professora tivesse acesso a aspectos desconhecidos sobre o bairro onde a escola se localizava, conhecesse os hábitos de seus alunos; os aprendizados e as reflexões dos alunos 
sobre as condições do bairro e os procedimentos de higiene; as discussões sobre o tema; as negociações de conteúdos; as divergências; as orientações em relação à maneira pela qual se apresenta, conduz e encerra um texto.

O fato de os registros em si não possibilitarem o resgate ou a compreensão dos processos que lhes deram origem é fundamental para o trabalho do psicólogo em intuições educacionais ou com crianças em idade escolar. Tais reflexões serão retomadas, com mais detalhamento e cuidado, no capítulo VI.

\section{III.4.4.2 Outras formas de autoria}

Ainda que a atividade de escrever textos possibilite momentos privilegiados de autoria, outras formas criadoras puderam ser encontradas.

O modo de organizar esteticamente os conteúdos registrados constituiu uma importante forma de autoria. As regras vigentes na sala de aula eram bastante flexíveis, permitindo que os alunos fizessem opções. Pular ou não pular linhas, fazer desenhos, usar lápis ou caneta, escolher as cores para escrever, definir o tipo de letra eram possibilidades para os alunos. Sem desrespeitar regra alguma da sala de aula, era possível que cada aluno tivesse uma apresentação diferenciada das informações que registrava. Os cadernos, não necessariamente, pareciam-se. Mas tomavam características personalizadas, que podem ser exemplificadas pela cópia que Cleber realizou do cabeçalho e do roteiro do dia, em novembro: 


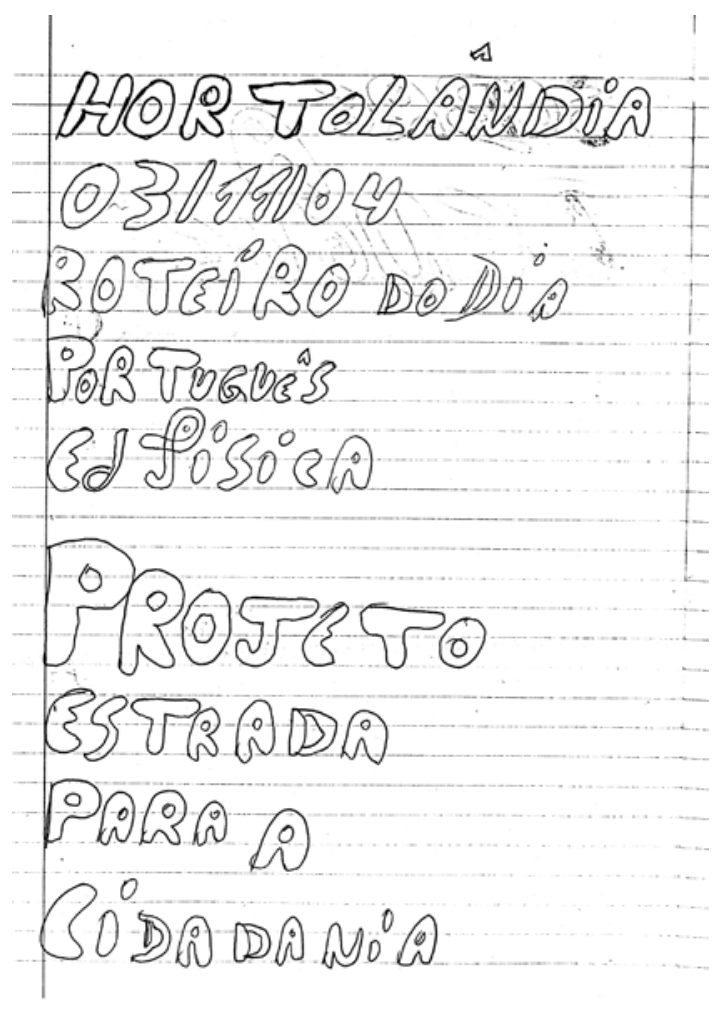

Figura 24. Roteiro do dia encontrado no caderno de Cleber

Uma situação ocorrida no início do ano, em março, exemplifica bem a liberdade dada aos alunos para decidir como iriam dispor as informações em seus cadernos. Para a resolução de um exercício de Matemática, era necessário construir uma tabela. A professora Silvia recomenda aos alunos que deixem oito linhas em branco. No entanto, uma das alunas, Paula, adota um padrão diferenciado para a cópia e a resolução dos exercícios: utiliza uma linha e deixa a seguinte em branco. Conhecendo essa forma de proceder da aluna, a professora recomenda a ela: "Aí, [como] você pula uma linha pra separar, 16" (RA-01). Ou seja, a própria professora adapta às instruções dadas ao padrão escolhido pela aluna para fazer a atividade. A cena ilustra tanto as possibilidades de escolhas existentes na sala de aula, quanto a aceitação e o apoio encontrados na escola para que cada aluno encontre modos individualizados de organização das tarefas escolares. 
Algumas situações em que os alunos deveriam realizar cópias também se revelaram momentos autorais. Cumprindo as tarefas de modo diferente do proposto, foi freqüente os alunos reformularem os conteúdos a ser copiados. Ao realizar a cópia do enunciado de um problema de matemática que tinha como tema um jogo de dardos, Fabiana substituiu por seis vezes a palavra "dardos" por "dados" 36 .

Heitor, por sua vez, ao copiar o cabeçalho e o roteiro do dia em 7 de outubro, fez algumas alterações.

Tabela 2. Comparação de registros entre a lousa e o caderno de Heitor

\begin{tabular}{ll}
\hline Na lousa & Cópia de Heitor \\
\hline Hortolândia 07/10/04 & Hortolândia 07/10/04 \\
Boa tarde! & Bom dia \\
Roteiro do dia & Roteiro do dia: \\
Teatro: A verdadeira história do lobo mau & Lanche \\
Português & A verdadeira história do lobo mal \\
Atividade & Portugueis \\
Conte a história como você entendeu & Atividade \\
& Conte a história que você entendeu \\
\hline
\end{tabular}

Um último exemplo dessa modalidade de autoria que consiste em fazer cópias modificadas vale ser citado. Ralph recebeu como castigo a incumbência de fazer diversas cópias da frase: "Não respeito a professora. Ela fala o tempo todo comigo e eu não estou nem aí." Depois de 16 cópias a frase sofreu uma modificação e passou a ser escrita da seguinte forma:

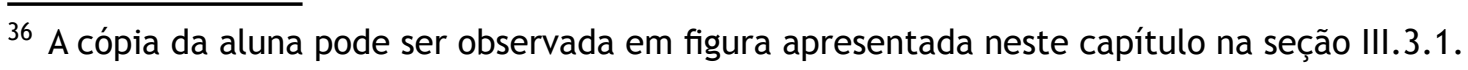




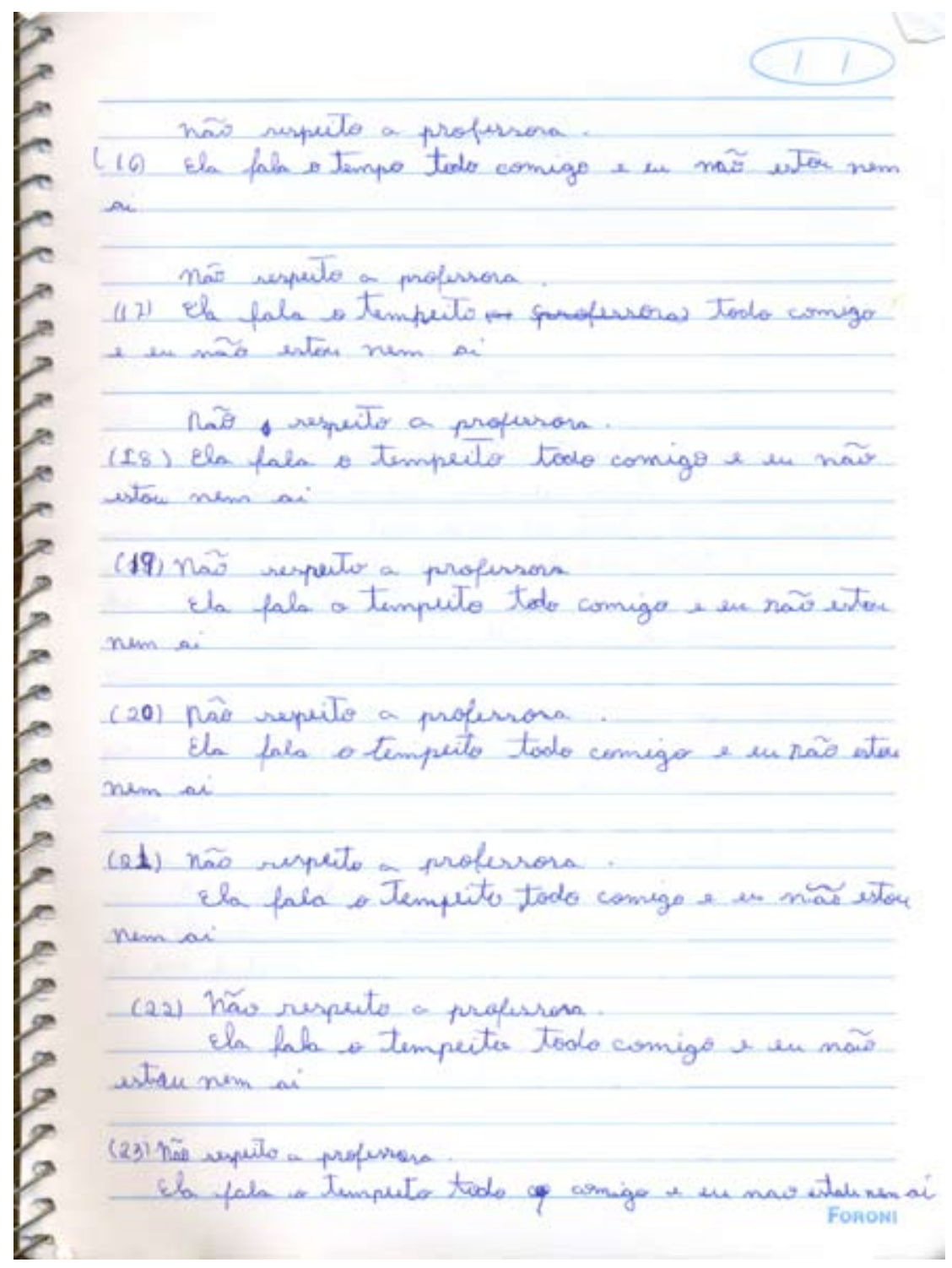

Figura 25. Castigo no caderno de Ralph ${ }^{37}$

Possivelmente nem todas as modificações efetuadas foram intencionais. Mas, sejam modificações acidentais, sejam deliberadas, foram formas de reorganizar os conteúdos de acordo com uma nova ordem que pareceu mais familiar, ou que fez mais sentido para os alunos. Possivelmente, Fabiana não conhecia a palavra "dardo" e, ao utilizar "dado", optou por uma forma com a qual estava mais acostumada. Heitor, ao realizar a cópia da lousa, reescreveu o roteiro do dia, fez adaptações em palavras e frases, acrescentou o lanche como uma das importantes atividades escolares a ser

${ }^{37}$ Frase escrita por Ralph, como cumprimento de castigo, a partir da $17^{\mathrm{a}}$ cópia: "Não respeito a professora. Ela fala o tempeito todo comigo e eu não estou nem aí." 
lembradas, trocou o boa tarde pelo bom dia. 0 castigo de Ralph traz um fenômeno mais obscuro. 0 aluno troca a palavra "tempo" pelo neologismo "tempeito". Mesmo conversando com Ralph a respeito, não foi possível compreender os meandros dessa alteração. Ele apenas riu envergonhado ao rever o resultado do que escreveu. Apresento duas hipóteses: uma delas, sugerida pelos desenhos de cunho sexual que compareciam em profusão em seus cadernos, é que a modificação teria ocorrido em razão das questões relativas à sexualidade e ao corpo feminino que tanto mobilizavam Ralph; outra possibilidade é que, baseado na primeira frase do castigo, Ralph teria mesclado as palavras tempo e respeito, sem nem mesmo perceber o engano.

Apresento, ainda, uma outra forma de criação que surpreendeu a professora Silvia: a inovação nos modos de resolução de exercícios matemáticos. Ela relatou, como exemplo dessa forma de autoria, uma situação em que propôs aos alunos um quadro mágico ${ }^{38}$. Alguns números do quadro foram apresentados e, além disso, informou-se que o somatório de cada linha e cada coluna deveria ser sempre 185:

Teve uma atividade que eu dei no quadro mágico, tanto nessa sala, quanto na outra. Era pra fazer uma operação inversa. Quando eu trouxe, tanto pra eles quanto pra outra turma, não foi na operação inversa que eles fizeram. Eles fizeram de várias maneiras e nenhuma criança fez do jeito que eu tinha pensado.

(Entrevista com Silvia)

Silvia esperava que os alunos, sabendo que a soma deveria ser 185 , fizessem a operação inversa, ou seja, a subtração, a fim de descobrir os números que completariam os quadrados. Em vez disso, diversas outras estratégias foram adotadas:

38 Quadro mágico é um problema matemático em que um quadro é dividido em quadrados que devem ser preenchidos com números. A peculiaridade é que a soma de cada uma das linhas verticais, horizontais ou diagonais, deve resultar num mesmo número. Por exemplo:

\begin{tabular}{|l|l|l|}
\hline 2 & 9 & 4 \\
\hline 7 & 5 & 3 \\
\hline 6 & 1 & 8 \\
\hline
\end{tabular}

Testando o quadro mágico do exemplo, temos que a soma de uma linha horizontal $(2+9+4)$ é igual à soma de uma linha diagonal $(2+5+8)$ e é igual à soma de uma linha vertical $(2+7+6)$, cujos resultados são 15 . 
Eles foram por aproximação. Teve criança que foi de um em um contando. Outros: "Ah, na unidade tem que dar cinco. Então, eu só vou usar número que dê cinco na soma". E não foram nem uma vez como eu tinha pensado!

(Entrevista com Silvia)

As formas de solução encontradas pelos alunos não são inéditas. São formas possíveis de resolução utilizadas, de modo intuitivo, por diversas pessoas. Então, onde reside o caráter criador? Reside no fato de que são formas de resolução não conhecidas pelos alunos. Diante do desafio de resolver a questão, eles buscaram formas de raciocínio. As buscas basearam-se nos conhecimentos que dominavam, mas resultaram em algoritmos diferenciados. São modos de proceder que pressupõem uma relação ativa com as informações numéricas. Em vez da repetição de procedimentos, ocorre uma reinvenção de estratégias de raciocínio.

\section{III.4.4.3 A repetição}

Os conteúdos dos registros estão repletos de formas autorais de organizar informações. Entretanto, ainda que esse aspecto tenha sido privilegiado até o momento, é importante ressaltar que nem sempre predomina a criação. A repetição também fez parte das atividades desenvolvidas na sala de aula.

Algumas das atividades propostas eram mais propícias a que os alunos apenas reproduzissem conteúdos, de modo mecânico e repetitivo, como é o caso da atividade de escrever números por extenso, solicitada ao menos por 10 vezes ao longo do ano letivo por Malu. A figura a seguir apresenta o início da tarefa cumprida por Cleber que consistiu em escrever por extenso os números de 500 a 700: 


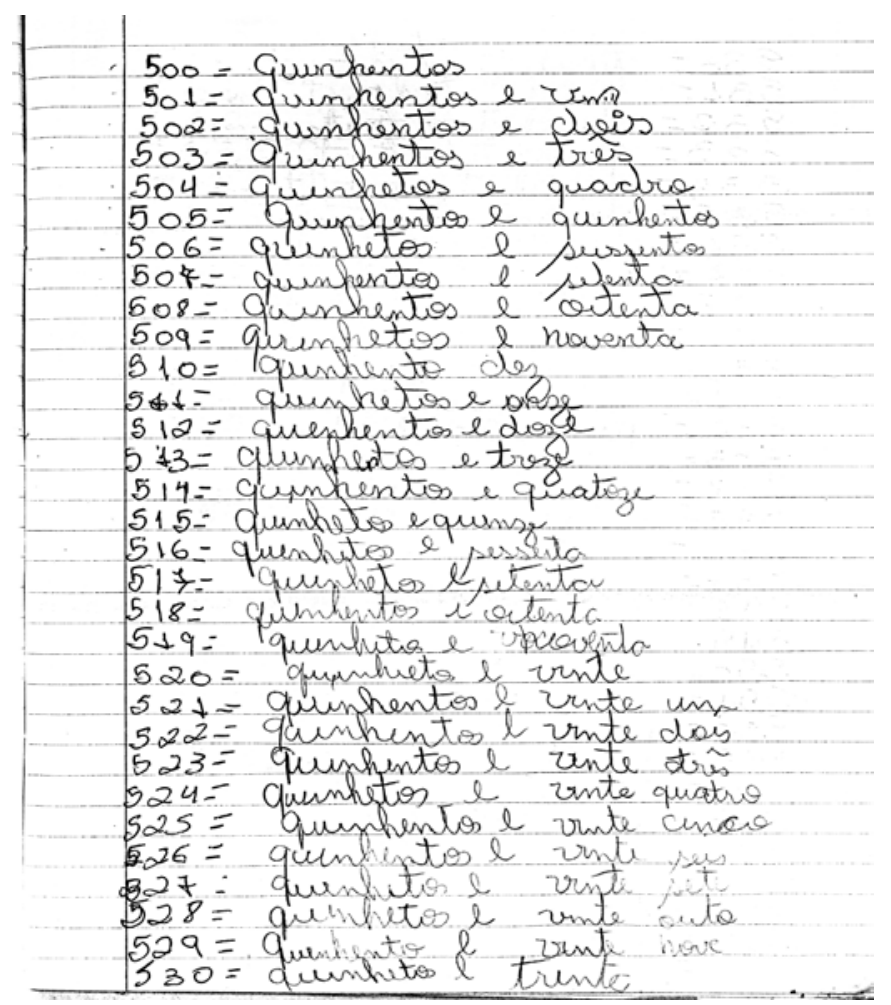

Figura 26. Números por extenso no caderno de Cleber

As cópias de textos, solicitadas com alguma freqüência, também foram momentos de realização de registros que abriam poucas possibilidades para a criação. Muitas vezes, foram momentos de reprodução mecânica que nem sequer possibilitaram aos alunos compreender o que copiavam. Foi o caso de um texto no qual era relatada a história de uma pessoa que se assustou com um esqueleto, copiado por alguns alunos:

Jordan vem me mostrar o texto que acabou de copiar. É um poema sobre alguém que fugiu de um esqueleto, ficou com medo. Diz que acabou e que agora só falta desenhar o esqueleto. Converso com ele sobre o conteúdo do texto copiado e ele me conta algo bastante diferente do que está registrado: "fala que tem que comer bastante para não ficar que nem ele" (indicando a figura do esqueleto). [...] Pergunto a Jackson, que acaba de copiar o texto do esqueleto, o que é que diz o texto, ele diz que não se lembra. Interessante observar que nenhum dos alunos com quem falei sabe o que copiou. 
Tanto Jordan como Jackson cumpriram a atividade solicitada com perfeição, fizeram cópias completas. Nenhum deles, porém, foi capaz de relatar o que estava escrito. Jordan, que ainda estava numa fase bastante inicial de alfabetização, não teria naquele momento condições de ler e compreender o texto. Assim, quando questionado a respeito do que havia escrito, inventou um conteúdo que mantinha relações com a figura do livro: um esqueleto.

Mesmo quando as atividades propostas se baseavam na criação, nem sempre a participação dos alunos se deu dessa forma. Continuarei apresentando algumas situações vividas por Jordan que poderão ilustrar isso. A participação de Jordan na construção do texto coletivo sobre a higiene no bairro foi assim descrita por ele:

Jordan: A dona passou um texto coletivo e eu não fiz. E copiei da lousa.

(Entrevista com Jordan e Uelinton)

Conforme foi apresentado na descrição do processo de construção do texto ${ }^{39}$, a participação dos alunos foi privilegiada. A professora solicitou aos alunos que não copiassem, pois teriam a oportunidade de fazê-lo posteriormente. Para os alunos que não cumprissem, havia um castigo: fazer a cópia novamente. Jordan não cumpriu o castigo e recebeu um bilhete:

Senhora mãe, hoje fizemos uma atividade chamada texto coletivo e pedi para que os alunos só copiassem quando terminássemos. 0 Jordan começou a copiar antes de todo mundo, e quando isso acontece, o aluno deve copiar duas vezes. Ele não quis copiar a segunda vez, e ainda ficou chupando bala o que é proibido, e jogando papel no chão, as balas foram guardadas no armário.

Silvia 16/04

(Texto de bilhete lido durante entrevista com Jordan e Uelinton)

Jordan explicou por que copiou antecipadamente o texto:

${ }^{39}$ A descrição do processo de construção desse texto coletivo foi apresentada na seção III.4.4.1 A autoria nas produções de texto, deste capítulo. 
Jordan: A dona falou que não era pra começar, ela estava falando, eu teimei e comecei. Eu queria terminar primeiro que todo mundo.

(Entrevista com Jordan e Uelinton)

Jordan foi um dos alunos da sala de aula que mais tiveram dificuldades. Tinha bons conhecimentos em matemática, mas ainda não estava alfabetizado. Silvia preocupavase muito com ele e freqüentemente preparava atividades especiais, visando garantir que ele aprendesse a ler e a escrever. Jordan, por sua vez, demandava muita atenção da professora, buscando todo o tempo auxílio e aprovação em relação ao que fazia:

Do Jordan, o que eu acho difícil de lidar é que ele pede atenção cinco horas por dia! [...] Aí ele traz o caderno, aí ele não usa o verso, mas ele quer que você fale que é pra ele usar... [...] Se ele está fazendo, ele pede ajuda. Se ele está a fim de fazer, ele pede ajuda.

(Entrevista com Silvia)

Apesar de ter obtido grandes avanços, durante o ano letivo, o garoto finalizou a quarta série sem ser capaz de produzir um texto simples. Por isso, foi retido.

Jordan era um típico aluno copista ${ }^{40}$. Conhecia bem suas limitações, assim como conhecia as possibilidades que um copista tem de cumprir certas atividades escolares:

Pesquisadora: Aí você já sabia escrever?

Jordan: Não, ainda não! O caderno inteiro, eu não sabia nem ler, nem escrever!

Pesquisadora: Inteirinho? E como você escreveu tudo isso se você não sabia?

Jordan: Copiando da lousa. Só copiava.

Pesquisadora: E só copiando dá pra fazer um caderno cheio de coisa assim?

Jordan: Dá.

(Entrevista com Jordan e Uelinton)

Em meio a um ano escolar tão marcado por insucessos, é compreensível que Jordan tenha se aproveitado, na situação da produção coletiva de texto, para fazer

\footnotetext{
40 Temple (2007) define o aluno copista da seguinte forma: "O aluno que desenvolveu a habilidade de escrever, mas não avançou à compreensão da linguagem escrita, que permaneceu apenas nesse momento de cópia. Os alunos copistas são capazes de copiar as atividades apresentadas pelo professor com bastante habilidade; conhecem algumas letras, sabem nomeá-las, mas não sabem ler. Também não sabem escrever quando solicitados que executem a atividade sozinhos."
} 
a atividade que dominava bem: copiar. 0 desejo dele era, além de fazer a cópia, fazer mais rápido que todos e sobressair-se por ter feito algo antes de seus colegas. Conforme descreve Temple (2007), para os alunos copistas, a realização da cópia assume grande importância, pois, ao realizá-la, aproximam-se das atividades que estão sendo feitas na sala. Mesmo que não saibam escrever, produzem algo escrito. É o momento em que a reprodução do que é apresentado na lousa os coloca, ainda que apenas na aparência, em condição de igualdade com os demais alunos da sala.

\section{III.4.4.4 Afinal, quem são os autores dos cadernos?}

Diante das informações apresentadas, vale retomar a questão: afinal, quem são os autores dos registros feitos na escola? Realmente, essa não é uma pergunta à qual se possa dar uma resposta simples.

Há momentos em que um caderno identificado por uma etiqueta com o nome de um aluno, o suposto autor, compila produções de outras pessoas (pais, colegas de sala, professora). Outras vezes, produções realizadas por um aluno apresentam um desempenho superior ao habitual e trazem a dúvida: será que foi o próprio aluno quem escreveu isso? Ocorre também de alunos imitarem o modo de escrever de pais e professores. Há, ainda, as produções coletivas, cuja autoria não pertence declaradamente a um indivíduo. Também é possível encontrar produtos resultantes de mediações diversas e irrecuperáveis pelo registro final.

São múltiplos os autores dos conteúdos registrados: alunos, professores, pais, escritores de livros didáticos, poetas e músicos. Em cada página, trecho ou frase é possível que diversos autores compareçam. Assim, ao copiar uma letra de música passada na lousa, os alunos conferem-lhe algo de pessoal, seja no modo de organização, seja nos adornos que adicionam, seja mesmo nas alterações que the imprimem. É isso que faz com que os cadernos se diferenciem entre si. Dessa forma, a autoria da cópia da letra de música divide-se. 
As diversas situações de sala de aula que acabei de apresentar ilustram os intrincados bastidores que dão origem ao que pode ser encontrado nos cadernos dos alunos. Embora tantas autorias estejam representadas nas atividades escolares, dificilmente é possível identificar unicamente com base nos registros quem, realmente, são os autores.

\section{III.5POR QUE E PARA QUE SÃO FEITOS TANTOS REGISTROS?}

A ação de registrar é uma das mais presentes na vida escolar dos alunos. É algo que ocupa grande parte do tempo que permanecem na escola e que caracteriza o papel do aluno. Perguntar por que e para que são feitos os registros nos remete a quais são os motivos, os fins e os sentidos subjacentes a essa atividade tão constitutiva do espaço escolar. As reflexões teóricas de Leontiev e Bakhtin sobre esses conceitos serão utilizadas para abordar essa questão bastante complexa. Não pretendo esgotar o tema, mas apenas apresentar algumas reflexões a esse respeito.

Os conceitos de significado e sentido são valiosos para compreender para que, e por que os registros fazem parte do dia-a-dia das salas de aulas. Tais conceitos são tomados tal como foram definidos inicialmente por Leontiev (1978), bem como pelas posteriores reflexões de Bakhtin (2003).

Leontiev (1978) apresenta os conceitos de significado e sentido no bojo da discussão sobre os estudos da consciência. $O$ autor defende que a consciência, o modo pelo qual esta se desenvolve, assim como a forma pela qual se constituem todos os processos psíquicos, dependem do modo de vida, ou seja, estão diretamente ligados às atividades desenvolvidas pelo sujeito.

As significações são "a cristalização da experiência e da prática sociais da humanidade." (LEONTIEV, 1978, p.94). O significado de um objeto é constituído e fixado na linguagem. É na significação lingüística, numa palavra ou numa locução, 
que se constitui o conteúdo da consciência social. A significação possibilita que o homem assimile a experiência humana generalizada e refletida.

Assim, temos os modos pelos quais os diversos suportes de registros são socialmente vistos e identificados. Os cadernos escolares, por exemplo, são vistos como objetos indissociáveis da idéia de estudo que materializam o trabalho escolar dos alunos. As provas, por sua vez, são identificadas como instrumentos supremos de avaliação. Os alunos têm acesso a essas formas de conceber os elementos que fazem parte da escolarização, freqüentemente, antes mesmo de sua iniciação no ensino formal.

A significação, ainda que seja algo essencialmente social, ganha existência nos indivíduos, ou seja, ocorre um processo por meio do qual um conceito se torna conceito para um indivíduo. Leontiev (1978) aponta que o homem depara com uma rede de significações pronta, mas o processo de assimilação de cada uma das significações é atravessado pelo sentido subjetivo e pessoal que cada objeto tem para ele. 0 sentido pessoal é algo que vai sendo criado na vida, por meio das atividades. É algo vinculado à vida concreta do indivíduo, às suas necessidades, motivos e sentimentos.

De um ponto de vista psicológico concreto, este sentido consciente é criado pela relação objectiva que se reflecte no cérebro do homem, entre aquilo que o incita a agir e aquilo para o qual sua acção se orienta como resultado imediato. Por outras palavras, o sentido consciente traduz a relação do motivo ao fim. (LEONTIEV, 1978, p. 97)

O motivo é aquilo que estimula uma atividade. Para compreender uma atividade, é primordial que se compreenda o que a desencadeia, por que ela ocorre. “A primeira condição para toda a atividade é uma necessidade" (LEONTIEV, 1978, p.107). E as necessidades humanas são de várias ordens e sofreram grandes alterações ao longo da história da humanidade. Das necessidades biológicas, passou-se a uma infinidade de necessidades novas, especificamente humanas e construídas historicamente. As necessidades de estudo e de conhecimento, por exemplo, não são necessidades naturais, mas necessidades que são criadas ao longo das experiências da vida. 
Os primeiros anos escolares são bastante importantes na formação deste tipo de necessidade (DAVIDOV, 1988).

Assim como as necessidades, os sentidos também são construídos. A cultura em que o indivíduo está inserido e os valores dos diversos grupos a que pertence comparecem na formação de sentidos. Nas situações e relações vividas, os sentidos são construídos e reconstruídos. Bakhtin (2003) fez algumas pertinentes reflexões a respeito de como o sentido se atualiza nas relações do indivíduo:

O sentido é potencialmente infinito, mas pode atualizar-se somente em contato com outro sentido (do outro) (...). Ele deve sempre contatar com outro sentido para revelar os novos elementos da sua perenidade (como a palavra revela os seus significados somente no contexto).

Desse modo, é por meio das atividades e experiências que compõem a escolarização dos alunos que se torna possível a formação de sentidos pessoais para o ato de ter cadernos, de fazer anotações, responder às provas. As possibilidades de criação de sentidos para a realização de registros são múltiplas e têm grande potencialidade de serem sempre renovadas. É nas relações estabelecidas no contexto de ensino que reside a possibilidade para a que os sentidos mais diversos sejam atribuídos à atividade de registrar conteúdos escolares. $\mathrm{O}$ ato de copiar e resolver contas de matemática pode, para alguns alunos, significar exercitar um novo conhecimento; para outros predomina o desejo de agradar o professor, para outros realizar um trabalho bonito é o que mais importa, outros fazem as atividades para não receber castigos.

Para compreendermos qual é o sentido pessoal que os registros assumem para os alunos, é necessário conhecer os motivos subjacentes à sua realização. $\mathrm{E}$ quais seriam os motivos e as necessidades dos alunos e professores da quarta série para a realização dos registros? Quais seriam os sentidos atribuídos à atividade de fazer registros?

Aescola tem como função "propiciar a aquisição dos instrumentos que possibilitam o acesso ao saber elaborado (ciência), bem como o próprio acesso aos rudimentos 
desse saber." (SAVIANI, 1996, p.19). Assim sendo, muitos dos registros solicitados aos alunos pelos professores têm como motivo possibilitar o acesso ao saber.

Foram diversas as estratégias utilizadas para mediar a tarefa de ensinar que resultaram em registros. Muitas delas compareceram fortemente nas descrições feitas até o momento.

Um dos recursos utilizados para favorecer a aprendizagem foi a realização de exercícios. Estes eram compostos por um enunciado solicitando que o aluno realizasse algum tipo de operação que se relacionava com os conteúdos abordados. As duas disciplinas que mais se valeram dessa estratégia foram Português e Matemática. Houve exercícios que trabalhavam com questões ortográficas e de compreensão de texto. Mas foi, sobretudo, em Matemática que os exercícios foram propostos. Ainda que os formatos e temas fossem muito variados, tais exercícios tinham como objetivo apresentar situações que poderiam ser resolvidas com as quatro operações matemáticas. Outra forma bastante usada para desenvolver a aplicação do raciocínio matemático eram as situações-problema.

Outra estratégia muito freqüente foi a cópia. Foram copiados enunciados de exercícios, bilhetes coletivos e, especialmente, textos. Os textos copiados foram utilizados posteriormente para fins diversos: trabalhar com aspectos gramaticais e/ou ortográficos, compreensão de texto, explicação de conteúdos relativos a ciências, história e até mesmo para promover o autoconhecimento. Ocorreu também a cópia de textos que se originavam de um trabalho anterior, como foi o caso dos textos coletivos.

Algumas das cópias serviam apenas como etapa preparatória para que as atividades fossem desenvolvidas, como é o caso dos enunciados de exercícios. 0 mesmo ocorreu em relação a alguns textos, cujo conteúdo servia para desencadear exercícios que tinham o intuito de exercitar outros saberes. Ainda que houvesse a intenção de que os alunos conhecessem e compreendessem o que tinham copiado algo imprescindível para a continuidade da atividade -, a ênfase recaía nas atividades feitas com base no texto. É o caso da atividade apresentada a seguir: 


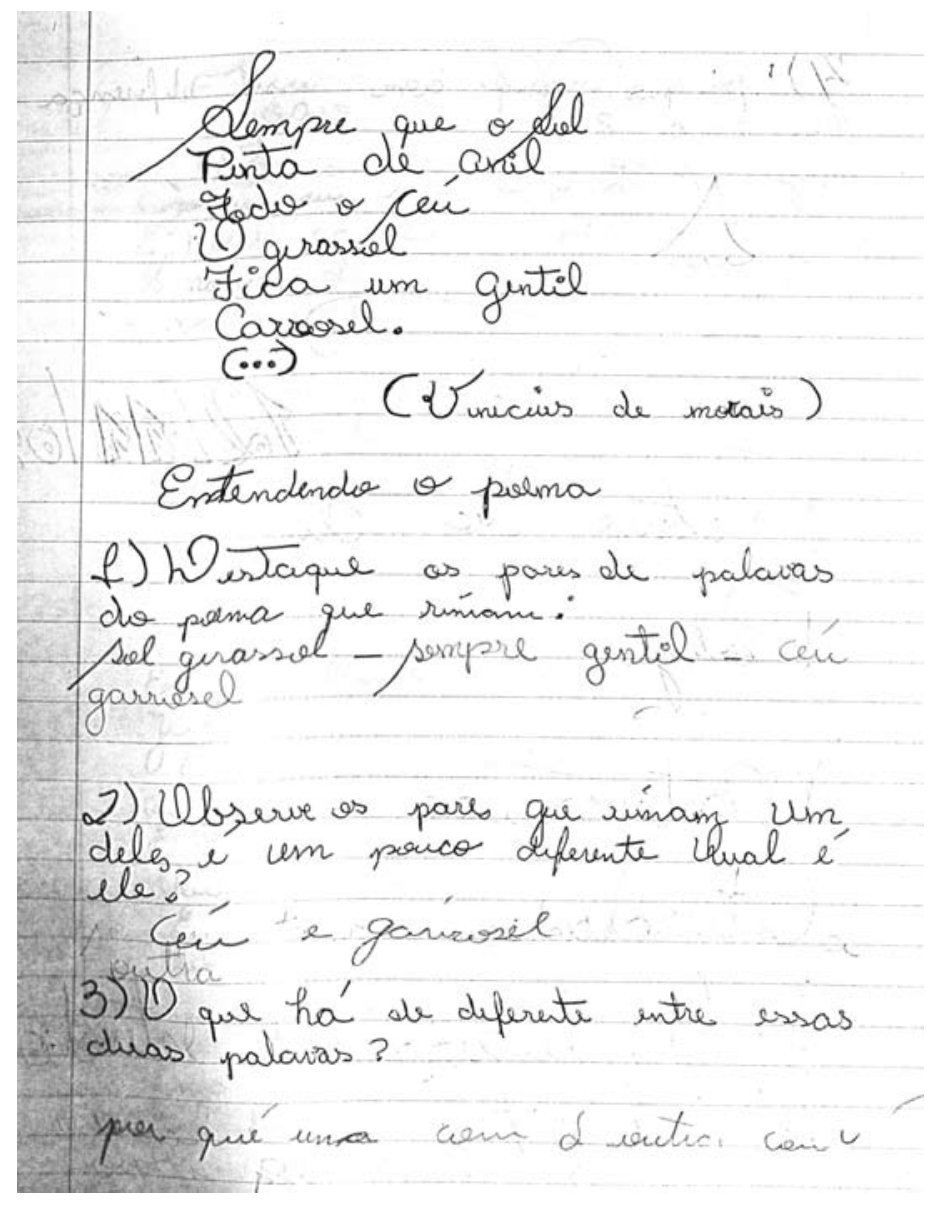

Figura 27. Poema e perguntas no caderno de Cleber ${ }^{41}$

Com base no poema de Vinicius de Morais, diversas perguntas são apresentadas. Muito mais do que a aprendizagem a respeito do girassol e o como essa flor se comporta quando há sol, as perguntas remetem-se questões de rima e ortografia presentes no texto.

${ }^{41}$ Conteúdo registrado no caderno de Cleber em 10 de novembro, com correções ortográficas: Sempre que o sol

Pinta de anil

Todo o céu

0 girassol

Fica um gentil carrossel

(...)

(Vinicius de Morais)

Entendendo o poema

1) Destaque os pares de palavras do poema que rimam: sol girassol - sempre gentil - céu carrossel

2) Observe os pares que rimam. Um deles é um pouco diferente. Qual é ele? Céu e carrosel.

3) 0 que há de diferente entre essas duas palavras? Por que uma (é) com l outra com u. 
Em outros momentos, o conteúdo copiado ganhava destaque como algo que deveria ser aprendido, como no caso de textos relativos a questões de saúde, higiene, conteúdos históricos, entre outros. Até mesmo as cópias realizadas como castigos tinham conteúdos que as professoras gostariam que seus alunos assimilassem ${ }^{42}$.

Outro motivo para que as professoras solicitassem cópias foi o desejo de que os alunos guardassem as informações tratadas na escola e as retomassem tempos depois, algo que foi expresso especialmente por Valéria:

Valéria diz que pensa no registro como algo "para daqui a alguns anos". Fala da possibilidade de daqui a alguns anos, "quando sobrar um tempinho", elas poderem ver coisas de que "não se lembram mais".

(RA-27 Entrevista com Valéria)

A professora chegou a dar exemplos de situações que possivelmente farão parte da vida dos alunos e que se relacionam com conteúdos registrados nos cadernos:

Valéria se pergunta: "será que daqui a alguns anos eles vão se lembrar se ter relações sexuais durante a gravidez 'machuca ou não' o bebê??" Hoje eles lembram, sabem. Mas será que daqui a alguns anos eles vão se lembrar? Aí daqui a alguns anos eles podem dar uma passadinha.

(RA-27 Entrevista com Valéria)

A prática de realizar cópias encerra uma possibilidade bastante grande de que a atividade seja realizada de modo meramente mecânico, sem que haja leitura ou compreensão do que é dito no conteúdo a ser reproduzido. Sabedoras desse risco implicado no tipo de atividade proposta, as professoras buscavam garantir que a realização da cópia pudesse constituir um momento de apreensão do conteúdo copiado. Um exemplo desse esforço ocorreu numa das aulas do Projeto Adolescer. A professora Valéria entregou folhas de papel sulfite aos alunos. Pediu que cada um colocasse o seu nome e uma qualidade que acreditasse ter. Em seguida, a folha passou a circular na sala de aula, e todos os alunos deveriam escrever, nas folhas de

\footnotetext{
${ }^{42}$ Como no castigo anteriormente citado, na seção III.3.1 Conteúdos registrados pelos alunos que foram propostos pelas professoras, em que Ralph teve de copiar um texto que se referia à importância do uso da expressão "por favor".
} 
seus colegas, as qualidades que reconheciam neles. Foi uma atividade que mobilizou bastante os alunos. Eles se empenharam em percorrer a sala, pedindo aos colegas que thes atribuíssem qualidades, e se divertiram, escrevendo nas folhinhas de seus colegas. A finalização da atividade consistiu em que cada aluno fizesse a cópia, no caderno, das qualidades a ele atribuídas:

Valéria pede aos alunos: "Eu quero que vocês copiem no caderno de vocês" [...] "Por que eu pedi para copiar?" Ela mesma explica: "Porque enquanto a gente está escrevendo a gente está lendo."

Mais do que apenas registrar uma atividade desenvolvida, Valéria tinha a intenção de que a ação de copiar possibilitasse aos alunos um processo de autoconhecimento e, até mesmo, uma mudança de auto-imagem:

Ela explica que "às vezes a gente só vê os nossos defeitos". Assim, a atividade teria o intuito de que eles se percebessem como pessoas com qualidades. Faz referência à adolescência, momento propício para que eles não se percebessem as próprias qualidades.

A fim de garantir seus objetivos com a realização da cópia:

Valéria enfatiza: "Quando vocês copiam, estejam lendo as qualidades que os colegas colocaram. Não é só para copiar."

Os alunos manifestaram-se de modos diversos em relação às atividades de fazer cópia. Alguns manifestaram gostar, outros não. Jordan, como apontado anteriormente $e^{43}$, era um aluno para quem a cópia tinha um sentido pessoal bastante importante. Era nesse tipo de atividade que ele conseguia ocupar a posição de aluno que cumpre as tarefas escolares com precisão. Eram os momentos de cópia que the possibilitavam executar algo bem-sucedido na escola. Ainda que tal significação aparecesse de forma mais evidente em Jordan, não era uma exclusividade dele a

$\overline{43}$ A relação de Jordan com as cópias foi descrita na seção III.4.4.3 A repetição. 
escolha por fazer cópias. Jackson, por exemplo, fez a opção de copiar em seu caderno um texto que apenas deveria ser lido:

Pergunto o que ele faz no caderno. Ele diz que está copiando para ler depois.

Pesquisadora: "Quem falou pra copiar?"

Jackson: "Eu que quero"

Houve alunos que reconheceram nas cópias uma possibilidade de aprendizagem. Por exemplo, durante a entrevista, Cleber referiu-se à prática de escrever textos como a melhor forma de aprender. Leonardo discordou, defendendo a cópia:

Leonardo: Quando eu copio da lousa, assim, eu presto mais atenção! Pesquisadora: Quando copia também aprende?

(Leonardo e Cleber fazem que sim com a cabeça)

(Entrevista com Leonardo e Cleber)

Para muitos alunos, a realização das cópias era movida por sentirem-se obrigados pela professora a realizá-la:

Ralph: "Professora, é obrigado a copiar isso aí, não é, dona?" Valéria não responde e Jordan pergunta a Ralph: “É obrigado?” Ralph responde de modo irônico: "Não". Vários alunos copiam, Ralph passa a copiar também.

Quando comecei a realizar as observações em sala de aula, a hipótese de que eu também estaria submetida à obrigação de copiar da lousa ocorreu a alguns alunos. Certo dia, quando a professora passava de carteira em carteira verificando os cadernos:

Igor me pergunta: "Você é obrigada a copiar a lição?"

Eu digo que não. Explico que eu copio, pois faz parte do meu trabalho.

Pergunto se ele é obrigado e ele diz que sim. 
Escrever e reescrever textos, de modo coletivo ou individual, foi um tipo de atividade bastante utilizado para trabalhar diversas questões relacionadas à escrita. Silvia e Malu referiram-se a esse procedimento como uma estratégia interessante para que os alunos apreendessem aspectos muito importantes da escrita, tais como o uso de parágrafos, títulos, pontuação, a organização do texto e das idéias a ser apresentadas.

Entre as professoras, foi Silvia quem se referiu especialmente às potencialidades de aprendizagens existentes na escrita e reescrita de textos. A professora relembrou suas experiências de faculdade, quando era comum escrever algo, entregar ao professor, receber as sugestões de correção e reescrever. Ela relatou que foi por meio desse processo que compreendeu:

Quando você escreve de novo e você lê, você melhora.

(Entrevista com Silvia)

Os alunos também referiram-se à escrita de textos como uma atividade importante para o aprendizado:

Leonardo: Todas as matérias que eu gosto é só coisa de texto!

Pesquisadora: De texto?

Cleber: É, você aprende mais a escrita!

P: Quando aprende mais a escrever? Quando você faz o texto?

C: É, quando nós mesmos fazemos o texto.

(Entrevista com Leonardo e Cleber)

Apesar de os alunos se referirem à escrita de textos como algo importante para que aprendam a escrever, tanto Silvia quanto Malu encontravam dificuldades quando propunham esse tipo de produção. Vários alunos manifestaram não gostar desse tipo de atividade:

Fabiana: Texto eu não gosto muito de fazer.

(Entrevista com Alex e Fabiana) 
E assim, nem sempre os alunos cumpriam o que era pedido, algo que ficou registrado nos cadernos sob a forma de temas propostos, porém não elaborados. Outras vezes, a qualidade das produções realizadas deixava as professoras insatisfeitas:

Malu comenta que os alunos "são muito desorganizados". Conta que trabalha com produção de texto e eles esquecem de colocar o título e de fazer os parágrafos.

E Silvia deu algumas explicações para isso:

Eles não fazem pra eles. 'Eu vou fazer pro professor'. Por isso que quando eles escrevem um texto eles não lêem pra perceber que tem palavra ali que está faltando letra e que ele não está entendendo. Porque quer entregar logo pra ficar livre, quanto mais rápido ele fizer, pra ele é melhor. Eu acho que é isso!

(Entrevista com Silvia)

Pude acompanhar diversas situações, ao longo das observações feitas em sala de aula, que evidenciaram as motivações citadas pela professora para a realização das atividades escolares. 0 desejo de ser bem visto, bem avaliado e reconhecido pela professora, bem como o medo de punições e repreensões, foram motivações que permearam a realização das tarefas escolares. A intenção de acabar rapidamente para poder brincar, dormir ou fazer bagunça também foi algo recorrente em minhas conversas com os alunos:

Fabiana: Na aula, quando eu termino a lição, eu peço pra dona deixar eu dormir. Ou fico brincando de alguma coisa.

Pesquisadora: E o que você fica fazendo (quando termina a lição), Alex?

Alex: Bagunça!

Pesquisadora: Que tipo de bagunça?

Fabiana: Correndo na sala.

Alex: Correndo na sala.

(Entrevista com Fabiana e Alex)

A escassez de motivações para a realização das atividades escolares que fossem relacionadas à necessidade de conhecer o que é ensinado na escola também foi de alguma forma explicada por Silvia: 
Eu acho que as aulas da gente tinham que ser mais interessantes. [...] Nós, professores, tínhamos que trabalhar um período e o outro preparar pra o outro dia. Mas, ir buscar. Porque hoje a gente fala assim, pra matemática, que muita coisa está mudando, que a gente aprendeu [de modo] mecânico [...] Mas eles têm que quebrar uma barreira entre como você aprendeu e o jeito que vai ensinar. Só que, aí, você não consegue sair daquilo. Só que, aí, você não tem tempo de elaborar coisas melhores e acaba ficando maçante e igual. E aí, o caderno fica o quê? "Ah, eu vou passar logo o que a professora faz, pra ela não me encher, pra eu deixar meu caderno organizado." Eu acho que é isso! Infelizmente é isso!

(Entrevista com Silvia)

A falta de condições de trabalho para o professor e as dificuldades encontradas para planejar as atividades foram apontadas pela professora como as principais razões para que os alunos não conseguissem encontrar motivações próprias a fim de cumprir as tarefas escolares. Silvia era uma professora que demonstrou, durante o semestre letivo que acompanhei, grande envolvimento com o trabalho docente. Tinha uma formação acadêmica superior à da maioria de suas colegas, sendo especialista em Educação Especial e tendo chegado a iniciar um mestrado. Suas aulas caracterizavamse por ter um ritmo acelerado. Sempre propunha diversas atividades em um mesmo dia e, freqüentemente, trazia algum tipo de material previamente preparado. Era, portanto, perceptível um razoável nível de planejamento do trabalho pedagógico. Ainda assim, a professora relatou o sentimento do quanto os seus esforços eram insuficientes para que os seus objetivos - que os alunos encontrassem motivações intrínsecas ao trabalho que realizam na escola - fossem alcançados. Tal sentimento remete à hipótese de que Silvia vivesse algum nível de burnout, categoria de sofrimento psíquico associado ao trabalho assim definido por Codo e Vasques-Menezes (2000):

Burnout é o nome da dor de um profissional encalacrado entre o que pode fazer e o que efetivamente consegue fazer, entre o que deve fazer e o que efetivamente pode, entre o céu de possibilidades e o inferno dos limites estruturais, entre a vitória e a frustração. (p.39) 
O desgaste emocional relacionado com o trabalho foi a causa atribuída por Silvia a um problema de pele que a deixou afastada do trabalho por uma semana no fim de abril.

No caso de Malu, o desgaste apresentou tons ainda mais garridos. Na semana que antecedeu o início das entrevistas com os alunos, Malu preocupou-se com o que os alunos iriam comentar a respeito dela. Revelou-me, então, saber que não fazia um trabalho tão bom quanto gostaria. A conversa, assim iniciada, continuou versando sobre todas as dificuldades enfrentadas por ela para conseguir trabalhar em dois municípios: longos percursos a ser transpostos a pé, a espera pelos ônibus, o tempo gasto com as deslocações, a necessidade de trabalhar aos domingos para compensar a ausência nos Horários de Trabalho Pedagógico Coletivo (HTPC). Malu comentou as dificuldades de ser um bom professor trabalhando em dois períodos, mas as necessidades financeiras não Ihe davam a opção de trabalhar menos. Sentia-se muito cansada e estressada. E, assim, teve dificuldades para acompanhar os cursos oferecidos pelo município. Sofria exigências para ingressar em um curso superior de Pedagogia e planejava dar início à faculdade no ano seguinte. As dificuldades financeiras e a falta de tempo seriam empecilhos grandes e que ainda não sabia bem como enfrentar. Ao longo do ano, diversos foram os sofrimentos físicos vividos pela professora nos meses em que acompanhei seu trabalho: dores nos pés e nas pernas, perda de voz, dores no peito, falta de ar, dores nos joelhos.

A exaustão emocional e física de Malu também pode ser caracterizada como uma forma de burnout. Tal como descreve Codo (2006), a professora estava encalacrada em uma situação de trabalho que não podia suportar, mas da qual também não podia desistir. Essa forma de sofrimento repercutia no trabalho desenvolvido com os alunos.

Nesse contexto, registrar cumpriu funções de ordens diversas na sala de aula, nem sempre diretamente ligadas a promover a aprendizagem dos alunos.

Houve momentos em que a solicitação de que os registros fossem realizados buscava manter os alunos ocupados. No meio de agosto, Valéria iniciou as aulas do Projeto Adolescer. Para que os alunos participassem desse projeto, era necessária a permissão dos pais. A escola providenciou circulares com uma breve descrição do 
projeto e um pedido de autorização que deveria ser assinado. Os alunos receberam esses documentos e deveriam apresentá-los no primeiro dia de aula para poder participar do projeto. No entanto, no dia em que Valéria veio à sala de aula para dar início ao seu trabalho com a classe, alguns alunos não tinham trazido as autorizações. Alguns tinham perdido, outros esqueceram. Nessa condição, não poderiam permanecer na sala de aula. Malu se encarregou deles.

Malu chama: "os que não estão com autorização vêm comigo". Os alunos vão saindo, Malu diz que vai dar um jogo para eles. Fabiana, que fica, diz indignada: “Jogo? Não é lição?" Malu desiste dos jogos, leva livros e pede que levem cadernos. Malu sai e vai ficar com os alunos.

(RA-17)

Após pouco mais de uma hora, Valéria encerrou o trabalho com a sala e os alunos que tinham ficado fora da sala retornaram. Jordan veio me mostrar o texto que copiou durante esse tempo. Vi que era um poema que contava uma situação em que uma pessoa ficava com medo ao ver um esqueleto e fugia. 0 texto foi copiado de um livro. Ao lado do poema, o desenho de um esqueleto. Quando perguntei a ele o que havia copiado, Jordan respondeu: "fala que tem que comer bastante para não ficar que nem ele". Outros alunos com quem conversei no mesmo dia também não souberam me dizer sobre o que falava o texto que tinham acabado de copiar.

A cena relatada ilustra uma das recorrentes utilizações dos cadernos na sala de aula: manter os alunos ocupados e, assim, manter a disciplina. 0 uso das atividades escolares como uma forma de garantir a ordem na sala de aula foi bastante freqüente:

Começa uma grande bagunça na sala. Malu ameaça: "vou dar lição pra vocês ficarem quietos." [...] Malu escreve na lousa um problema de Matemática e muitos alunos copiam.

Malu ameaça: "Se bagunçarem, eu passo lição." 
As comunicações com os pais também eram uma forma encontrada pelas professoras para que os alunos fizessem as atividades e mantivessem a disciplina. Os bilhetes comumente denunciavam atos de indisciplina e/ou a não realização de tarefas. Além disso, solicitavam - de modo explícito ou implícito - algum tipo de medida a ser tomada pelos pais, para garantir que os alunos agissem em conformidade com as regras escolares.

Não eram apenas os bilhetes que se direcionavam aos pais. Tanto Malu quanto Silvia manifestaram preocupações em relação a possíveis reclamações dos pais a respeito do trabalho que desenvolviam. Silvia, por exemplo, contou sobre um dia no qual diversas atividades foram desenvolvidas com os alunos: fizeram avaliação de Matemática, elaboraram uma história em quadrinhos sobre reciclagem e, por fim, assistiram a um filme. Nenhuma das atividades resultou em registros nos cadernos:

E no caderno não tinha nada. Então, se é um pai que acompanha, que pega o caderno da criança, ele fala assim: "Nossa você não fez nada na escola hoje?". E tem criança que, dependendo da atividade, fala: "não". Porque pra criança, se você brincar, ela não fez atividade! Então, se fala: "Você não fez nada hoje?" e ele fala: “Não", tem pai que vem reclamando! Às vezes é esse tipo de reclamação, às vezes é porque ele não gosta do jeito que você trabalha! Aí ele fala que ele discorda, que você não é uma boa professora, que ele quer mudar o filho dele com a outra professora, tem dessas reclamações assim.

(Entrevista com Silvia)

Silvia revela o quanto os cadernos funcionam como instrumentos de controle dos pais sobre o trabalho desenvolvido na escola. Por serem objetos que transitam na escola e nas casas das crianças, favorecem a circulação de informações entre esses dois espaços e prestam, com freqüência, à avaliação do trabalho do professor (SANTOS, 2002). Quando não há nada registrado, aumenta a possibilidade de que os pais reclamem.

Ambas as professoras comentaram que não tiveram problema algum com a sala de aula estudada. Nenhum pai fez reclamações sobre a quantidade ou a qualidade do trabalho realizado por elas. Ainda assim, tal preocupação motivava a solicitação de que os alunos fizessem diversos registros: 
Eu gosto que registre, mesmo que não tenha nenhuma lição pra passar no caderno. [...] Teve um dia que eu passei um filme, vai estar lá registrado que eu vou passar um filme, entendeu? Porque o pai tem que saber, se vai pegar o caderno do filho e ele vai ver o que a professora deu hoje, entendeu? Então é isso, registro é pra isso!

(Entrevista com Malu)

A frase com que Malu encerra o assunto é bastante reveladora a respeito de para que são feitos alguns dos registros:

O caderno é mesmo pra dizer que você trabalhou. De uma forma mais bonita!

(Entrevista com Malu)

Diversas atividades registradas tiveram como elemento motivador a preocupação com os pais. No entanto, a atividade diária que mais diretamente direcionava-se a comunicar aos pais o que tinha sido realizado na escola era o roteiro do dia, uma listagem das atividades que seriam desenvolvidas no dia, copiada logo em seguida à data.

Entre as várias razões para que os registros sejam feitos, uma delas é a avaliação dos conhecimentos dos alunos. Como vimos, solicitar registros e corrigi-los é uma prática diária e utilizada permanentemente. Diante disso, seria possível considerar que os documentos que vão sendo produzidos ao longo dos dias letivos possibilitariam um modo de avaliação contínua dos aprendizados e do desenvolvimento dos alunos.

Embora as potencialidades avaliativas existentes nos registros diários sejam muito grandes, foi importante verificar que tanto alunos quanto professoras atribuíam relevância secundária a esses instrumentos para a avaliação.

Quando perguntei às professoras se utilizavam os cadernos para a avaliação, a resposta imediata foi negativa.

Pesquisadora: E você acha que dá pra avaliar um aluno pelo caderno dele?

Malu: Pelo caderno? Só pelo caderno? Não!

(Entrevista com Malu) 
Pesquisadora: E você consegue usar quanto desse registro que eles fazem pra avaliação? Você usa isso?

Silvia: Eu uso não os cadernos para a avaliação. Nem a prova, assim. Eu uso o oral deles.

(Entrevista com Silvia)

A recusa das professoras em relação a avaliar os alunos por meio do que produzem em seu cadernos ficou com mais clara quando explicaram o que compreendiam por avaliar os cadernos:

Silvia: Eu não avalio [pelo caderno], igual tem professor que dá nota pelo caderno. Falar assim: "O caderno mais organizado vai ganhar isso", eu não acho justo! Tem gente que não tem o dom de ser organizado, não tem letra bonita. Eu mesma, eu acho que meu caderno não era organizado, bonito.

(Entrevista com Silvia)

Malu: Não adianta ser organizado, fazer tudo bonitinho no caderno, se ele não consegue produzir um texto, se ele não consegue resolver uma operação. Pelo menos uma operação, entendeu? Por que tem aluno que é super organizado, mas depois não consegue fazer nada.

(Entrevista com Malu)

Ou seja, para as professoras, usar os cadernos para avaliar os alunos significava levar em conta o aspecto formal da apresentação das informações nesses materiais escolares. Ambas diziam não considerar um critério importante a organização e a estética apresentadas nos cadernos. Alegaram, porém, atentar na avaliação dos alunos para conhecimentos freqüentemente expressos nos registros diários, tais como a habilidade de fazer contas e de redigir textos.

Quando conversei com os alunos a respeito de quais eram os fatores que as professoras levavam em consideração para avaliar, os cadernos foram citados. No entanto, nunca apareceram como os fatores mais importantes: 
Pesquisadora: E o que vai contar (na avaliação) além da prova?

Cleber: Aprendizagem na sala de aula e o comportamento!

Pesquisadora: Como (a professora) vai saber a aprendizagem na sala de aula?

Cleber: Porque ela olha o caderno todo dia. Quando termina, ela fala: "Todo mundo que terminou vem e mostra". Aí, ela vai olhando, vai corrigindo, vai dando as notas.

(Entrevista com Cleber e Leonardo)

Pesquisadora: E o que você acha? Ela (a professora) vai olhar no caderno pra ver quem vai passar e quem não vai?

Ralph: Ah, acho que ela vai ver assim como é que está o comportamento na sala de aula, a obediência e vai ver quem está sabendo fazer as coisas direito, ver o caderno pra saber quem está sabendo escrever. [...] $\mathrm{E}$, depois da prova, ela vai dizer se vai passar de ano ou se não vai!

(Entrevista com Ralph e Igor)

Além das atividades estritamente escolares, em vários momentos os alunos faziam registros não solicitados pelas professoras. Esse assunto foi abordado em tópicos anteriores e, por ora, vale a pena ser retomado, uma vez que esses registros tinham um papel fundamental para que os cadernos adquirissem importantes sentidos pessoais. Foi o caso dos desenhos.

Longe de serem apenas detalhes decorativos, os desenhos assumiam para alguns alunos uma importância que se sobrepunha a todo o restante registrado. Eram produções altamente valorizadas por eles e dignas de orgulho. Walkíria gostava tanto de fazer desenhos e de reunir desenhos de seus colegas que acabou reservando um caderno unicamente para isso. Alan, por sua vez, separou uma das disciplinas de seu caderno para fazer os desenhos. Em entrevista, Cleber e Leonardo contaram que, quando jogavam fora seus cadernos, tomavam o cuidado de retirar antes os desenhos. Igor fez questão de trazer desenhos atuais e outros que tinha feito nos cadernos da segunda série para que eu visse. Ralph também dedicou algum tempo da entrevista mostrando seus desenhos, ainda que bastante envergonhado.

Ao perceber o sentido que os desenhos realizados têm para seus autores, podese compreender melhor a tolerância - e, por vezes, o incentivo - que as professoras 
dispensavam a essas manifestações. Cleber relatou que um de seus colegas tinha muitos desenhos nos cadernos, e a professora consentia:

Cleber: Ele tem um par de desenhos no caderno dele, de vez em quando a professora dá visto nos cadernos, a professora não fala nada!

(Entrevista com Cleber e Leonardo)

Outro aspecto importante para compreender para que se registra é o fim que é dado a esses registros ${ }^{44}$. Nas entrevistas com os alunos, houve a manifestação de procedimentos diversos em relação ao que faziam com os cadernos depois que estavam completamente preenchidos.

A maioria disse que, depois de finalizada a utilização escolar, os cadernos são jogados no lixo.

Pesquisadora: Não tem nenhum que você guardou?

(Leonardo faz um não com a cabeça)

Pesquisadora: E por que você joga fora?

Leonardo: Costume...

Pesquisadora: Costume? E depois que acaba, você acha que serve pra alguma coisa?

Leonardo: Pra mim não!

(Entrevista com Cleber e Leonardo)

Pesquisadora: E, quando acaba (o caderno), o que você faz?

Alex: Eu jogava fora!

Pesquisadora: Quando você jogava fora?

Alex: Sempre que acabava.

Pesquisadora: Sempre?

Alex faz um gesto afirmativo com a cabeça.

Pesquisadora: E por que você jogava fora?

Alex: Porque eu acho que não tinha utilidade.

(Entrevista com Alex e Fabiana)

O fato de os cadernos serem jogados fora, após preenchidos, sugere que sejam suportes cujo valor reside na possibilidade de serem utilizados para a realização das diversas atividades. Os alunos não encontrariam razões para preservar os conteúdos por eles produzidos. No caso desses alunos, guardar ou não os cadernos não era

\footnotetext{
${ }^{44}$ A questão da terminalidade dos cadernos também foi abordada em Santos (2002).
} 
uma questão que os preocupava. Apenas se desfaziam do que tinha sido útil por um tempo, mas não era mais.

Ralph foi um aluno que descartou diversos cadernos ao longo do ano. Dois desses cadernos me foram entregues. Nem sempre os cadernos dos quais se livrava estavam terminados, freqüentemente tinham ainda diversas folhas em branco que poderiam ser utilizadas. Na entrevista, Silvia comentou sobre isso:

Ralph vira e mexe está com um caderno novo! Que ele fala que o caderno dele está relaxado, aí ele troca. [...]

P: Você sabe o que ele faz com o caderno?

S: Eu não sei o que ele faz! Mas ele, vira e mexe, troca e fala assim: "Ah, meu caderno estava muito bagunçado!". Porque ele fica atrasado, né? Aí, ele pula folha, só que depois ele não põe em ordem. Aí, quando eu falo: “Ah, vou olhar o caderno". Aí, eu falo: "Ih, Ralph, seu caderno está bagunçado". Daí, ele fala: "Não. Eu vou arrumar!". Daí, ele aparece com um caderno novo! Porque ele quer ter um caderno caprichado.

(Entrevista com Silvia)

O próprio Ralph chegou a comentar sobre essa preocupação em apresentar à professora o caderno organizado:

Ralph diz que ficou fazendo umas coisas no caderno durante a manhã, passando a limpo, copiando, pois está preocupado. Malu avisou que o caderno vai contar na hora de decidir quem vai passar de ano.

(RA-29)

Para Ralph, abandonar um caderno e iniciar outro era como um ritual por meio do qual se propunha, a partir daquele momento, a ser mais aplicado e organizado. Ao descartar o caderno antigo, descartava também produções - incompletas e desorganizadas - que simbolizavam uma forma de ser aluno que não era a que ele tinha como ideal. A cada novo caderno - preenchido tanto por atividades elaboradas com esmero, como por páginas em branco e atividades não realizadas ou incompletas - renovavam-se as intenções de ser um aluno diferente.

O fato de que apenas os cadernos dos bons alunos sejam preservados foi abordado por diversos autores (GVIRTZ, 1997; BUKIET e MÉROU, 2000; CHARTIER, 
2003) e repetiu-se na sala de aula estudada. Todos os que manifestaram sempre guardar e achar importante fazê-lo se caracterizavam por ser bons alunos. Walkíria, ótima aluna que permaneceu apenas os primeiros meses na escola onde foi realizado o estudo, me contou que guardava todos os seus cadernos. Mantinha esse costume desde a primeira série e ficou muito pesarosa por ter perdido alguns exemplares, molhados pela chuva. Foi a única aluna que me explicou o motivo pelo qual mantinha suas produções:

"Eu acho interessante a gente guardar recordações"

Ela planejava uma utilidade para os cadernos guardados:

Com 20 anos, quando eu estiver com meu namorado, vou olhar com ele: "Olha como era a minha letra, horrorosa."

Dessa forma, Walkíria guardava os cadernos, pois podia, por meio deles, lembrar e mostrar sua trajetória a pessoas queridas.

Fabiana e Uelinton comentaram, na entrevista, a respeito de guardar seus cadernos:

Uelinton: Eu guardo meus cadernos! Eu guardo todos!

(Entrevista com Jordan e Uelinton)

Pesquisadora: Guardava todos?

Fabiana: Todos!

Pesquisadora: Desde quando você entrou na escola?

Fabiana faz um sim com a cabeça.

(Entrevista com Alex e Fabiana)

Nenhum desses dois alunos tinha um motivo específico para manter seus cadernos. Entretanto, os cadernos guardados acabaram sendo utilizados de algum modo; no caso de Fabiana, para brincar de escolinha com as primas. Era em seus antigos cadernos que ela se inspirava para passar lições. Na casa de Uelinton, os 
cadernos passavam por uma censura. A mãe reservava apenas os mais "caprichados" para mostrar à madrinha de Uelinton.

Assim, os atos de jogar fora cadernos e de guardá-los contêm uma infinidade de significações possíveis. Descobri-las não é uma tarefa fácil e exige uma análise cuidadosa das motivações individuais que levam a guardar ou não as próprias produções escolares.

\section{III.6 COMO, POR QUE E PARA QUE SÃO FEITAS AS PROVAS?}

As provas são um suporte de registro bastante diferenciado dos demais utilizados na escola. Com o intuito de melhor contemplar as peculiaridades desse tipo de documento, a descrição de como, por que e para que as provas são feitas será reunida numa seção única.

Enquanto fazer registros nos cadernos é algo que compõe a rotina da escola, fazer provas é algo que institui uma ruptura na seqüência habitual. É um momento que mobiliza professores e alunos, despertando expectativas e sentimentos.

Como aplicar as provas era uma questão que mobilizava as professoras, elas se questionavam a respeito de quais seriam os procedimentos mais adequados a adotar por ocasião da realização dessas avaliações formais. Malu adotou o procedimento de não avisar previamente os alunos sobre a data em que a prova seria aplicada.

"Eu não falo que é prova [...] Tem aluno que se derrete". Comenta que até mesmo bons alunos "se derretem" e acabam indo mal na prova.

(RA-28)

Silvia, diferentemente, avisava sempre os alunos, com a intenção de que eles estudassem. 
Pesquisadora: Quando tem prova, por exemplo? Como eles estudam? Silvia: Eles não estudam! (Responde rapidamente)

Pesquisadora: Você marca a prova?

Silvia: Marco! Tal dia vai ter prova. Vai cair isso, isso e isso! Aí chegam aqui e eles não sabem porque eles não estudaram.

(Entrevista com Silvia)

A professora, porém, relatou uma experiência recente a partir da qual passou a questionar se esse seria o melhor procedimento:

Então, aí eu não avisei. Começaram a fazer a atividade aí eu falei: "Ah, então, eu tenho uma surpresinha: vocês vão fazer uma prova de matemática”. Aí eles ficaram assim: “Ai que chato!”. Então não deu tempo de eles ficarem pensando em casa, sabe? Aí, eles foram melhor na prova! Sem ter avisado, sem ficar com aquele medo de não conseguir fazer! [...] Acho que foi até melhor do que avisar antes, esperando que eles fossem estudar alguma coisa!

(Entrevista com Silvia)

As dúvidas das professoras sobre avisar previamente ou não a respeito da realização da prova relacionavam-se com as emoções despertadas por esse momento de avaliação. Embora a afetividade esteja presente em tudo o que é desenvolvido na escola, a avaliação é um momento que, mais evidentemente, produz marcas afetivas (KAGER, 2006). Uma das razões para que houvesse um envolvimento emocional tão grande com essa atividade era o fato de os alunos atribuírem à nota tirada na prova um grande poder decisório sobre o seu futuro escolar. Tomarei as declarações de Cleber e Leonardo para ilustrar esse fenômeno.

Cleber e Leonardo são alunos que passaram pela experiência de serem reprovados ao final da segunda série. Muito amigos desde essa época, receberam juntos a notícia de que teriam que cursar novamente a mesma série: 
Cleber: Olha que na última prova a gente tirou a mesma nota... Leonardo: Nota cinco!

Cleber: É. E ela (a professora) falou que quem tirasse menos de seis repetia! Estávamos, eu e o Lelê, sentados na carteira um do lado do outro. A gente se esforçando. Daí a dona falou: "Lelê, cinco!", aí, o Lelê já abaixou a cabeça. (...) Aí, “Cleber, cinco também!”. Daí eu falei, nossa, combinamos, Lelê, de repetir!

(Entrevista com Cleber e Leonardo)

Para Cleber e Leonardo, foi a nota da última prova o fator decisivo para que fossem reprovados. Quando conversamos a respeito de como seria a decisão da professora sobre a aprovação ou reprovação dos alunos, no ano corrente, voltaram a falar sobre o valor das notas nas provas:

Pesquisadora (sobre Alan): Ele foi mal?

Cleber: Ele tirou cinco na de português! Pode repetir, se a professora quiser.

Pesquisadora: Quanto que precisa tirar pra passar?

Cleber: Oito pra cima!

Pesquisadora: Oito pra cima?

Leonardo: Oito ou cinco?

Pesquisadora: Oito ou cinco?

Cleber: Não. Que nem de seis pra cima. Não pode ser de cinco pra baixo, que já é nota baixa!

Pesquisadora: Se tirar seis, passa?

Cleber: Passa!

Pesquisadora: Se tirar sete?

Cleber: Passa! Oito, nove, passa!

Pesquisadora: Se tirar cinco e meio, passa?

Cleber: Passa!

Pesquisadora: Passa?

Cleber: Passa!

Pesquisadora: Passa, Lelê?

Leonardo: Eu acho que passa!

Pesquisadora: E se tirar cinco?

Cleber: Não! Aí, fica no meio a meio! Aí, tem que ficar pra ver se vai aprender...

(Entrevista com Cleber e Leonardo)

A conversa com os alunos exemplifica a falta de clareza que os alunos têm a respeito de quais são os critérios utilizados para decidir aprovações e reprovações. Apesar de não saberem especificar como é tomada a resolução, têm várias hipóteses. Cleber começa dizendo que é preciso tirar oito para ser aprovado. Leonardo questiona, 
e eles concluem que seria necessário tirar acima de cinco e meio. No caso de o aluno tirar cinco, outros critérios seriam utilizados para que o veredicto fosse dado: a aprendizagem em sala de aula e o comportamento.

Sendo um instrumento tão poderoso de decidir destinos, não surpreendem os sentimentos despertados pelas provas nos alunos. Talita definiu a prova como uma situação difícil 45 . Jordan deixou de fazer uma das provas por não ter se sentido bem:

Pesquisadora: Você não fez a prova?

Jordan: Só uma. A outra eu não fiz. Estava com dor na barriga!

(Entrevista com Jordan e Uelinton)

Uelinton relatou o quanto a ansiedade despertada pela prova fazia com que ele não fosse capaz de mostrar o que sabia:

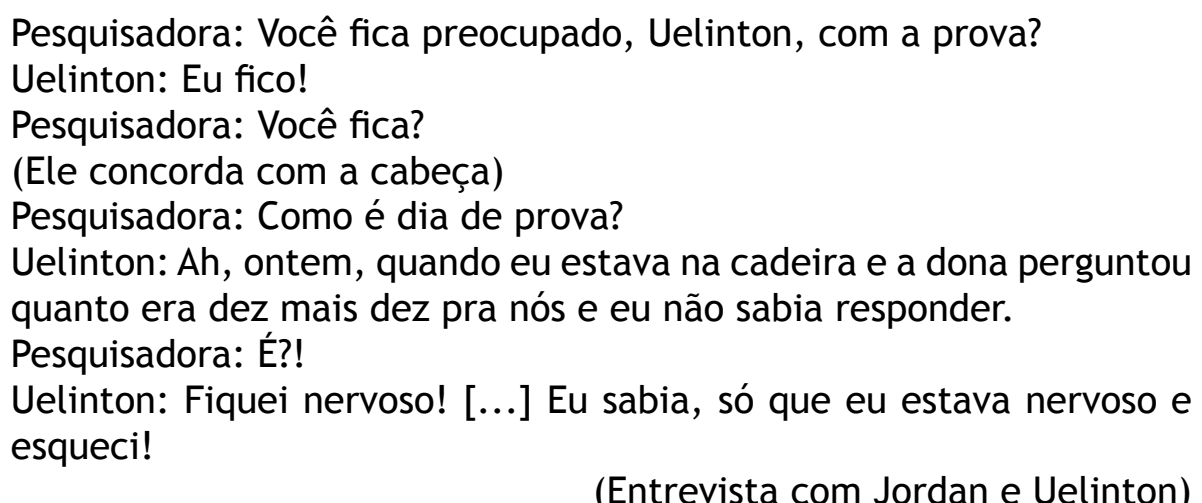

Apesar de ter ficado tão apreensivo em relação às provas, Uelinton acabou se saindo muito bem nas avaliações. Obteve notas altas e, na avaliação de Português, fez uma redação que surpreendeu a professora pela boa qualidade do texto e pela sensibilidade poética.

No geral, os bons alunos demonstraram maior tranqüilidade em relação às avaliações do que os alunos com percursos escolares mais atribulados. Durante as entrevistas, pedi aos alunos que elaborassem uma prova, respondessem a ela e a

$\overline{45}$ Declaração registrada no RA-06 e citada na abertura do presente capítulo. 
corrigissem. A disciplina, a extensão, o formato e as questões foram decididos e elaborados pelos alunos.

As produções de Fabiana e Ralph ilustram as diferenças nos significados atribuídos às provas por alunos com histórias escolares diversas.

Fabiana, uma ótima aluna com um histórico escolar de sucesso e aprovações, preparou as seguintes provas:

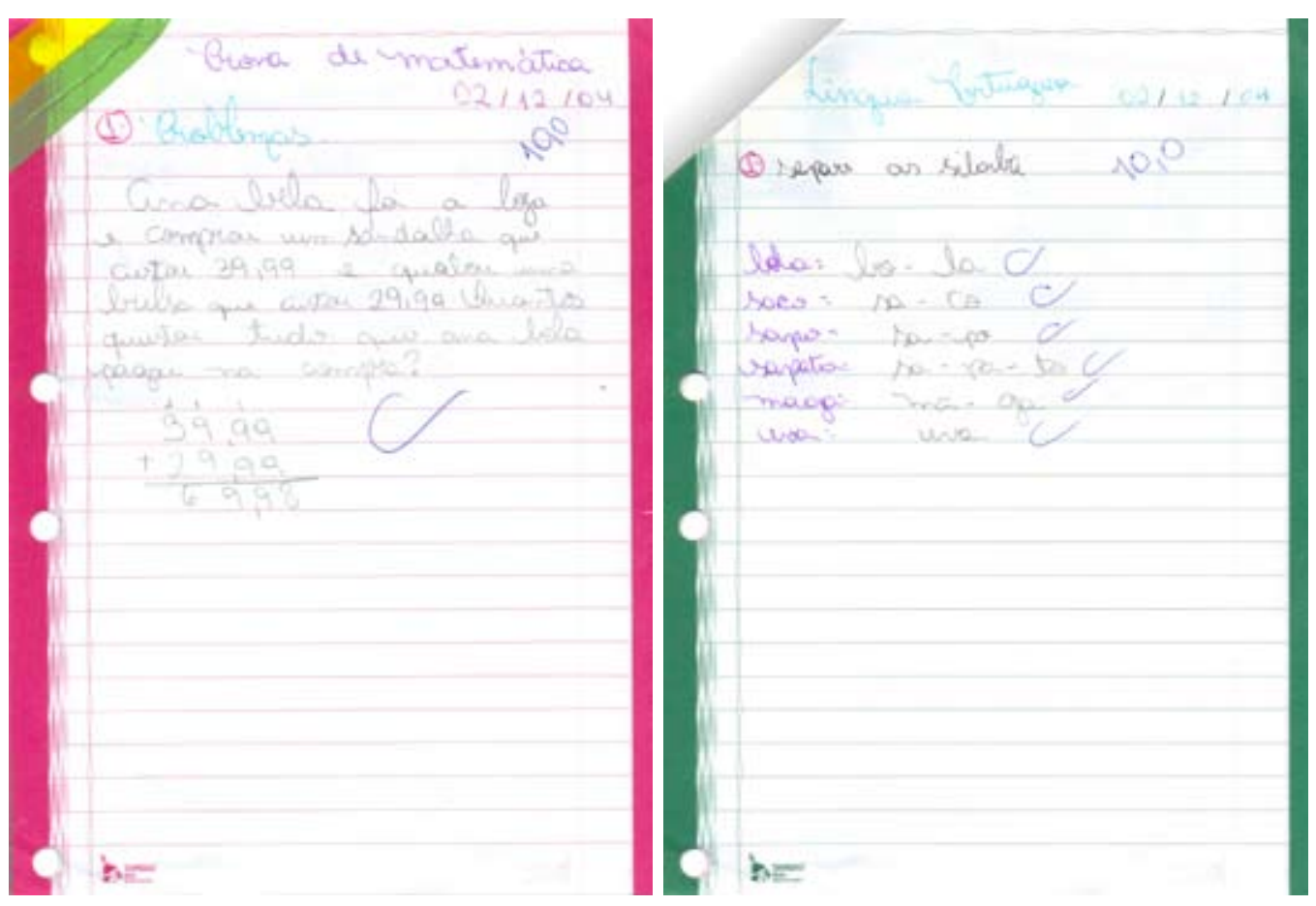

Figura 28. Provas elaboradas, resolvidas e corrigidas por Fabiana ${ }^{46}$

${ }^{46}$ Conteúdo das provas elaboradas por Fabiana, com correções ortográficas:

Prova de Matemática 02/12/04 Nota: 10,0

1- Problemas

Anabela foi à loja e comprou uma sandália que custou 39,99 e comprou (?) uma bolsa (ou blusa) que custou 29,99. Quanto custou tudo que Anabela pagou na compra?

$39,99+29,99=69,98$

Língua Portuguesa 02/12/04 Nota: 10,0

1- Separe as sílabas

bola $=$ bo-la

saco $=$ sa-co

sapo $=$ sa-po

sapato $=$ sa-pa-to

maga $=$ ma-ga

uva $=$ uva 
Foram duas provas, uma de Português e outra de Matemática. Ambas compostas por uma única questão, cuja resolução era razoavelmente simples e aquém das potencialidades e conhecimentos da aluna. As questões foram resolvidas sem grandes dificuldades. Ao corrigir, Fabiana foi bastante generosa consigo mesma e, desconsiderando uma falha na separação de sílabas da palavra "uva", atribuiu a nota 10 às suas provas.

A prova elaborada por Ralph foi sensivelmente diferente:

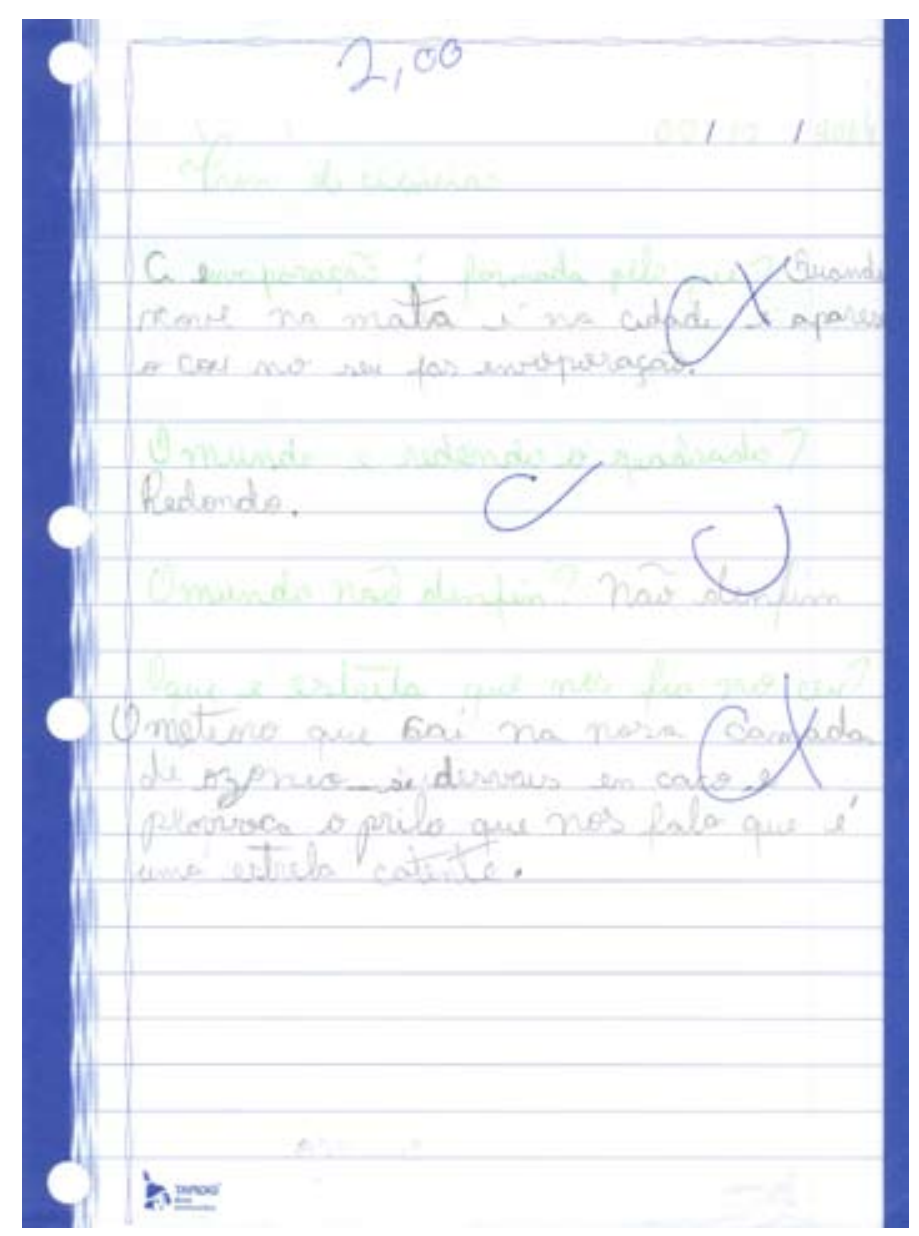

Figura 29. Prova elaborada, resolvida e corrigida por Ralph ${ }^{47}$

\footnotetext{
47 Conteúdo da prova elaborada por Ralph, com correções ortográficas:
Prova de Ciências
$02 / 12 / 2004$
Nota: 2,00

A evaporação é formada pelo quê? Quando chove na mata e na cidade aparece o sol no céu faz evaporação.

0 mundo é redondo ou quadrado? Redondo.

0 mundo não tem fim? Não tem fim.

0 que é [a] estrela que nós viu no céu? 0 meteoro que cai na nossa camada de ozônio se desfaz em caco e provoca o brilho (?) que nós fala que é uma estrela cadente.
} 
Ralph, que fez a quarta série com 12 anos, teve uma trajetória escolar confusa e com alguns pontos que permaneceram obscuros, mesmo após conversar com ele e com sua a família a esse respeito. Fez a terceira e a quarta série na escola onde foi realizado o estudo. Antes disso, passou por escolas de Campinas e Americana. Após diversos contratempos - aguardar por meses uma vaga na escola para poder se matriculado; ser expulso por mau comportamento, por ter brigado com um colega; e ter sido obrigado a cursar novamente uma série na qual acreditava ter sido aprovado -, Ralph chegou à quarta série em um estágio bastante inicial da alfabetização. Destacava-se na sala de aula pelas perguntas inteligentes e pelo alto grau de informação. Durante o ano letivo que acompanhei, fez grandes progressos na escrita. A prova produzida por ele mostra que, apesar dos diversos erros ortográficos, Ralph conseguia expressar suas idéias por meio da escrita.

Ralph optou por formular uma prova de Ciências, composta por quatro perguntas. Das quatro perguntas, duas previam respostas diretas, incluídas no enunciado da questão: a segunda e a terceira. A segunda questão - referente à forma de nosso planeta - era compatível com os conteúdos aprendidos, e Ralph foi capaz de responder a ela. Para a questão referente à finitude do mundo - tema bastante complexo, tanto do ponto de vista científico, quanto do filosófico -, Ralph também foi capaz de encontrar uma resposta que o satisfez. A primeira e a quarta perguntas também são complexas e têm enunciados pouco claros para o leitor. Para Ralph, no entanto, os enunciados foram elaborados prevendo as respostas que pretendia dar. A resposta à primeira pergunta deixa claro o seu objetivo de abordar a questão da evaporação que ocorre no ciclo da água, tema bastante destacado ao longo do ano letivo. Na última pergunta, Ralph pretendia tratar do fenômeno das estrelas cadentes. Ambos os temas propostos por ele têm explicações complicadas. Ralph elaborou respostas de acordo com seus conhecimentos, mas não reconheceu em suas formulações a abrangência necessária. Ao corrigir, adotou o "C" cortado que simboliza algo parcialmente correto. Para as demais questões, foi condescendente 
consigo próprio. A nota final, no entanto, é baixa. Apenas as questões corretas são consideradas e, sem adotar alguma regra de proporcionalidade, atribuiu apenas "2" à avaliação elaborada, respondida e corrigida por ele mesmo.

O modo escolhido pelos alunos para representar as provas expressa algumas das significações por eles atribuídas a esse instrumento de avaliação. Para Fabiana, a prova era um momento que servia para que a professora conhecesse o que os alunos sabem:

Fabiana: Eu acho que a prova não é só pra você passar de ano, é pra saber assim como a pessoa está, o jeito que ela está naquela prova, se ela está fazendo bem. Como a dona passou na prova de Língua Portuguesa, passou pra gente fazer um texto. Por exemplo, pra mim, eu pensei que ela queria saber nossa letra, pra saber se a gente faz um texto melhor.

(Grupo com Ralph e Fabiana)

A prova foi apresentada pela aluna como algo pouco ameaçador. Ela era uma aluna que, geralmente, conhecia o conteúdo e bastava a ela mostrar isso na prova. Assim, as provas eram atividades que não representavam momentos especialmente difíceis da escolarização:

Pesquisadora: 0 que você achou da prova?

Fabiana: Foi fácil.

(Grupo com Ralph e Fabiana)

Diferentemente para Ralph, a prova era algo que o preocupava. Freqüentemente, perguntava à professora quando seriam as provas.

Ralph: Professora, quando a gente vai ter a próxima prova?

O aluno se preocupava, pois sentia a necessidade de estudar para poder fazer as avaliações. Freqüentemente tirava notas baixas, assim como na prova que ele mesmo corrigiu. Chama a atenção o fato de Ralph ter se proposto a resolver questões cuja resposta não saberia dar de modo completo. Ele próprio criou uma armadilha, da qual não conseguiu sair. 0 modo pelo qual Ralph lidou com a situação proposta na 
pesquisa sugere uma forma de conceber as provas. Ele apresentou esses instrumentos de avaliação contendo questões de difícil resolução e nos quais as possibilidades de se sair são bem restritas.

Mas a que se prestam as provas, no contexto de ensino?

Se, para os alunos, as provas realmente representam algo que sela destinos, para as professoras os motivos para a utilização das provas são outros.

Malu: É, foram eles que pediram (as provas). Porque eles acham que a prova é que vai falar se eles vão passar de ano, entendeu? Imagina, é só no dia-a-dia mesmo, filha!

(Entrevista com Malu)

A significação social de prova atribui a esse instrumento a finalidade de avaliar os conhecimentos do aluno. Esse, porém, não era o sentido que as professoras que participaram da pesquisa atribuíam a tal forma de avaliação. A realização de provas não agradava a nenhuma das educadoras. Silvia comentou isso numa das conversas com a pesquisadora, em junho:

Perguntei sobre uma gincana cultural que ela estava organizando com a sala. Ela contou que foi muito boa. [...] Contou que se surpreendeu com a sala, pois tiveram um desempenho acima das expectativas. [...] No geral, percebe que os alunos demonstram muito mais conhecimentos nesse tipo de atividade do que costuma acontecer quando ela dá provas. Comenta que o desempenho em provas, em geral, é muito inferior.

Malu também foi enfática, em diversos momentos, ao afirmar que as provas não auxiliam o professor na avaliação dos conhecimentos de seus alunos:

Conta que não queria dar prova. [...] Diz saber muito bem quem sabe e quem não sabe na sala de aula. "Então, eu não sei quem sabe e quem não sabe fazer conta?"

Além de manifestarem que outros procedimentos, utilizados na rotina da sala de aula, são mais interessantes para avaliar os conhecimentos, as professoras 
questionaram a possibilidade de que a prova fosse uma avaliação que abrangesse o processo de desenvolvimento de cada aluno:

Aí, faz aquele monte de prova. E às vezes você vai lá, soma as notas e divide por dois! E aí você não analisou nada do crescimento do aluno.

(Entrevista com Silvia)

Apesar de não apreciarem essa forma de avaliação, ambas trouxeram um fator importante para utilizá-la: o fato de a prova ser um documento.

Aí no conselho, quando tem o conselho de classe para os alunos que têm mais dificuldade e vão ficar com nota vermelha, aí eu levo. Esse é um documento que eu tenho [...] Eu acho, assim, que a prova é um documento. Mas ela não é tudo.

(Entrevista Silvia)

Tanto Silvia quanto Malu referiram-se ao fato de ser necessário guardar provas no caso de se pretender reter um aluno:

Malu diz que o professor precisa ter documentos para comprovar que um aluno não pode passar, pois o pai pode entrar na justiça.

Assim sendo, a prova, muito mais do que um instrumento diagnóstico do processo de desenvolvimento dos alunos ou um referencial que poderia servir ao professor para avaliar e conduzir o trabalho pedagógico, presta-se a resguardar o professor. As provas ganham, portanto, um sentido jurídico de comprovar que o professor tomou uma decisão acertada.

\section{III.7 FINALIZANDO}

O presente capítulo teve o intuito de descrever o modo pelo qual os registros se inseriam no contexto escolar de uma sala de aula de quarta série de uma escola 
pública. Teve a intenção também de descrever como esses registros passavam a fazer parte da rotina, das relações e das decisões que constituíam tal espaço.

Por meio da busca pelas respostas a cinco questões-chave - onde, quem, como, por que e para que se registra -, foi realizada uma descrição dos meandros que envolveram a prática de realizar registros no contexto de ensino de uma sala de aula de quarta série, um processo que estabelece relações diversas com o objetivo mor da educação escolar: possibilitar o acesso ao conhecimento acumulado pela humanidade. Por vezes, as atividades que envolviam registros eram absolutamente comprometidas com esse grande objetivo, outras vezes ocorriam tentativas que se afastavam desse objetivo. Havia momentos em que registrar apenas resvalava na possibilidade de garantir o aprendizado e outros momentos em que, por circunstâncias institucionais diversas, registrar prestava-se exatamente a manter os alunos distantes da possibilidade de ampliar seus conhecimentos.

A partir de agora, outros contextos nos quais também são produzidos registros serão analisados: uma primeira série de escola brasileira e salas de aula francesas. Com base no que há de comum e de diferente, buscarei acrescentar elementos à compreensão de como os registros se inserem nos contextos escolares e passam fazer parte destes. 


\section{REGISTROS NA PRIMEIRA E QUARTA SÉRIES: percursos de uma aprendizagem fundamental para a inserção na cultura escolar}

No capítulo anterior, foi descrito o modo pelo qual os registros são utilizados numa sala de aula de quarta série, momento em que, após pelo menos três anos de vivência no contexto escolar, diversos conhecimentos relativos aos conteúdos, ao funcionamento e às regras da escola estão razoavelmente garantidos. Mas como acontecem tais aprendizados? Quais são os percursos necessários para que os alunos possam, efetivamente, participar das atividades que envolvem a prática de fazer registros?

Neste capítulo, serão descritos aspectos da trajetória necessária para que, ao chegar à quarta série, tais saberes deixem de constituir obstáculos às demais aprendizagens escolares. Será pela análise de como os alunos se iniciam na prática de fazer os registros escolares, que se pretende fazer alguns apontamentos sobre o percurso necessário para que os alunos de quarta série manifestem familiaridade com atividades tais como a realização de provas ou de anotações e exercícios nos cadernos.

A primeira e a quarta séries ${ }^{48}$ representam o início e o encerramento de um ciclo. No caso da escola pesquisada, a primeira série representava para quase todos os alunos a primeira oportunidade de uso escolar de cadernos. Em razão da escassez de vagas para a pré-escola, foi possível acompanhar o início da escolarização da maioria dos alunos, ou seja, o momento em que se dava a aprendizagem do uso escolar de cadernos.

A quarta série, por sua vez, encerra a etapa em que os alunos têm uma professora que os acompanha na quase totalidade do tempo letivo, propondo e corrigindo atividades de diversas disciplinas, organizando as regras sob as quais trabalhará a sala de aula e verificando aquilo que os alunos produzem.

\footnotetext{
${ }^{48}$ As informações foram recolhidas em 2000 e 2004, quando a primeira etapa do ensino fundamental ainda tinha apenas quatro anos.
} 
Ao acompanhar o ano inicial e final dessa etapa de quatro anos de escolarização, foi possível conhecer importantes aspectos do modo pelo qual os alunos se iniciam na utilização de cadernos e realização de registros e como, aos poucos, adquirem autonomia para fazer desses materiais escolares espaços autorais, repletos de marcas pessoais.

\section{IV.1 PRIMEIRA SÉRIE: MOMENTO DE INICIAÇÃO}

Ao conviver durante todo um ano com os alunos da primeira série, pude acompanhar o início de vários processos, entre os quais a inserção dos alunos no contexto escolar e o início da aprendizagem formalizada da leitura e da escrita. Em ambos, os cadernos participam como importantes mediadores.

Ao entrar na escola, faz-se necessário que o aluno se insira na cultura escolar, ou seja, no conjunto de práticas e normas vigentes na instituição de ensino. É preciso aprender o que se deve fazer, em quais momentos e de que modo. Os cadernos fazem parte desses aprendizados. Há saberes necessários para a escolarização que são estritamente ligados ao fato de se utilizar esse suporte de escrita, isto é, os cadernos produzem saberes escolares (GVIRTZ, 1997). É necessário que o aluno saiba que o caderno é composto de capa, contracapa e folhas; que as folhas têm margem e linhas. Para utilizar o caderno, é necessário saber que as tarefas devem suceder-se umas às outras, é preciso dominar as regras de cópia de conteúdos da lousa, entre muitos outros saberes. São conhecimentos que aparecem de forma tão consolidada nos alunos que têm algum tempo de permanência na escola, que chegam a parecer saberes intuitivos, que não careceriam de aprendizado.

Além desses saberes mais gerais a respeito da utilização dos cadernos, que se mantêm na maioria das instituições de ensino, há outros variáveis. As variações presentes no modo de uso proposto e exigido dependem da metodologia utilizada no ensino, das condições concretas existentes, de questões institucionais e até mesmo das preferências pessoais do professor. Dessa forma, é possível que apenas o uso de lápis preto seja permitido ou, diferentemente, que seja solicitado e incentivado o uso 
de lápis de cor e até de canetas. Pode ser que o correto numa determinada sala de aula seja escrever até o limite marcado pela sombra da linha vermelha da margem, enquanto em outra classe seja solicitado que o aluno escreva até o final da linha.

Ao entrar na escola, há uma infinidade de normas e procedimentos a ser aprendidos. $\mathrm{O}$ uso dos cadernos, com toda a complexidade e diversidade de saberes que reúne, faz parte dessa inserção. Algumas crianças, após alguns percalços, adquirem um mínimo de conhecimentos que permite que utilizem os cadernos como suporte para a realização das atividades escolares. Para muitos professores, não é clara a necessidade de ensinar os alunos como se deve trabalhar com os cadernos.

Por ocasião da realização das observações na sala de aula de primeira série, pude estabelecer importante troca de informações com a professora. Eram momentos em que, a partir das situações ocorridas em sala de aula, manifestavam-se muitas reflexões a respeito do uso dos cadernos. Uma das conversas com Ana, a professora da primeira série que acompanhei, foi reveladora a respeito do quanto o aprendizado do uso dos cadernos nem sempre participava das preocupações docentes. Em outubro, ou seja, próximo ao final do ano letivo, ela revelou sua recente constatação: "Não é natural para elas [as crianças] usar o caderno". Tal constatação foi possibilitada quando conversávamos a respeito de Severino, um dos alunos de sua classe.

Na primeira série do ensino fundamental, Severino estava no seu primeiro ano de escolarização. Era uma criança que raramente conversava com os colegas, ou se envolvia em brincadeiras. Passava a maior parte do tempo só. Sua fisionomia revelava seriedade, e sua postura, sobriedade. Em sala de aula, estava sempre sentado à sua mesa, tendo à frente os materiais escolares envolvidos nas tarefas propostas. Buscava todo o tempo realizar as atividades escolares, sem obter sucesso. Diferentemente da maioria de seus colegas, procurava pouco a professora para obter esclarecimentos ou mostrar o que fazia. Era um aluno reservado.

Seu desempenho acadêmico na primeira série foi bastante fraco, como fica evidenciado na figura apresentada no capítulo I e agora retomada: 


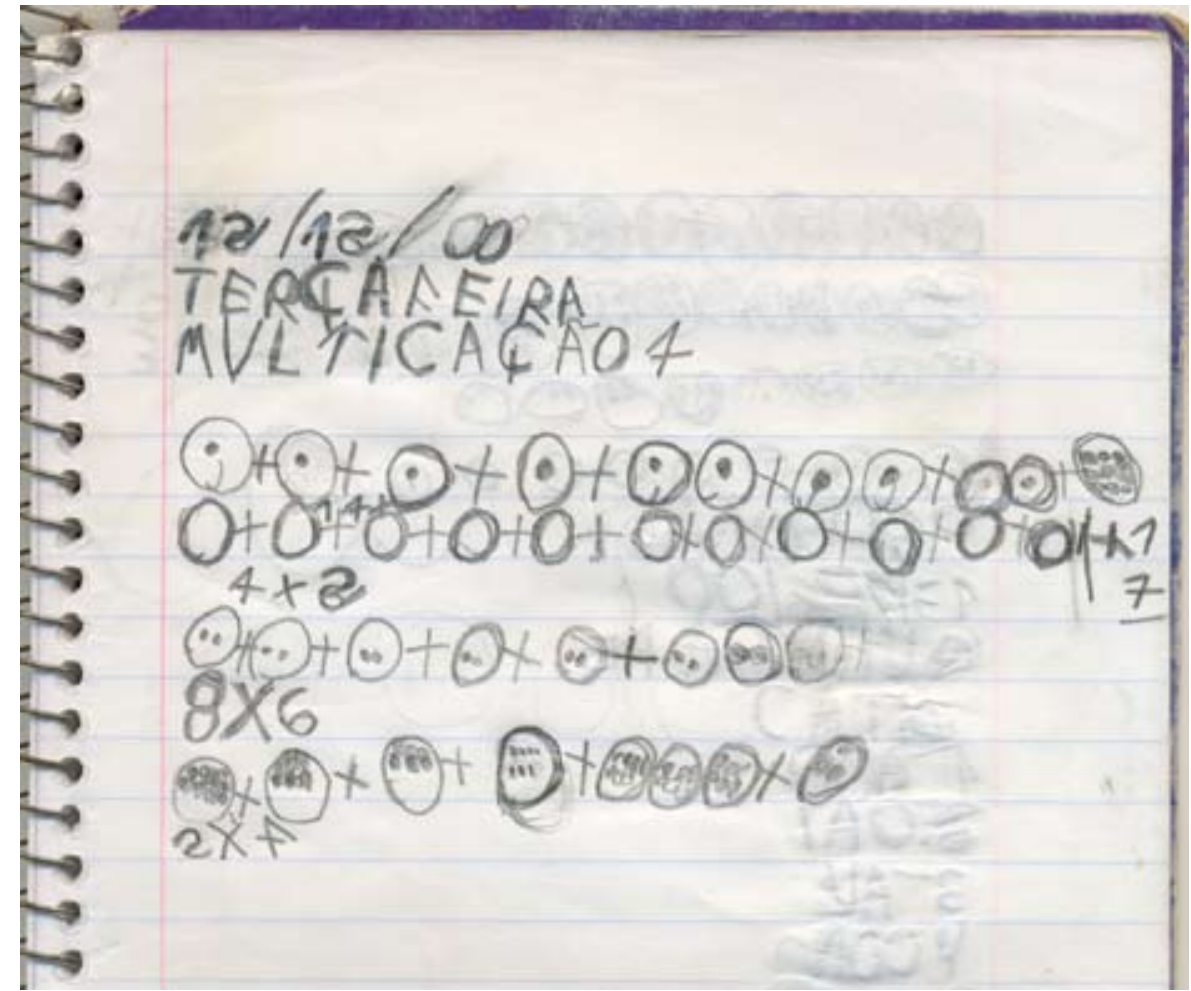

Figura 30. Cópia sobre a multiplicação do número 7, realizada em dezembro por Severino

Nos cadernos de Severino, não foi possível encontrar dias em que as lições foram feitas de modo completo e correto. Ainda assim, é possível afirmar que progrediu ao longo do ano. No início, quando ainda não estava familiarizado com o formato de letras e números, seu caderno mostrava apenas tentativas, malsucedidas, de cópia do cabeçalho. Após alguns meses, era possível encontrar, além do cabeçalho, atividades copiadas e a resolução de alguns exercícios. Foram progressos sensíveis, ainda que insatisfatórios.

No entanto, o aprendizado de alguns preceitos básicos da realização de cópias nos cadernos absorveu Severino de tal forma que, durante boa parte do ano letivo, não pôde se dedicar aos demais saberes abordados. A cópia de pequenos conteúdos, freqüentemente, exigia de Severino horas de dedicação. Durante as observações em sala de aula, foi possível acompanhar uma situação em que 1 hora e meia foi dedicada 
à cópia do cabeçalho ${ }^{49}$. Ele começava ora pelas primeiras letras de cada linha, ora pelas últimas. Não se satisfazendo com o resultado, apagava e reescrevia diversas vezes. 0 traçado das letras ainda não era algo que dominava bem; então, algumas eram desenhadas, sem muito sucesso. 0 resultado final de um intenso trabalho era, em geral, bastante confuso, incompleto e incompreensível.

Essas cenas se repetiram ao longo do ano, e Severino ficou cada vez mais atrasado, em termos de aprendizagem, em relação aos seus colegas. Mas o que tanto perseguia o aluno ao copiar? Por que tal atividade the tomava tanta dedicação e atenção? Não era possível deduzir isso pelos seus cadernos e nem por meio da simples observação de seu trabalho. Para compreender o que ocorria com Severino, tive que empreender uma cuidadosa aproximação. Foram necessárias diversas horas de observação e uma busca reiterada por conversar com ele sobre o que fazia. Após muito buscar a resposta, um dia Severino revelou-me o que the causava tantas dificuldades: "A linha de lá [da lousa] é grande e essa [a do caderno] é pequena." Ou seja, Severino empenhava-se em reproduzir aquilo que estava na lousa tal e qual como era apresentado. Assim, quando uma frase estava colocada na lousa, em uma única linha, ele procurava fazê-la também em uma linha de seu caderno, tarefa que se revelava difícil na maioria das vezes, especialmente pelo fato de seu caderno ser pequeno e de sua letra ser grande.

De modo algum tal objetivo pode ser considerado sem razão. Era recorrente ouvir recomendações da professora a toda a sala para que fizessem igual ao que estava na lousa. Severino, que não conseguia ainda diferenciar em que momentos era fundamental fazer igual e em quais era possível fazer adaptações, apenas buscava cumprir o que the era freqüentemente solicitado. Imerso em tais preocupações, o aluno deixava de voltar sua atenção para os conteúdos realmente fundamentais dessa etapa da escolarização.

49 O conteúdo do cabeçalho era:

HORTOLÂNDIA, 29 DE MAIO DE 2000.

TERÇA FEIRA

EU SOU CAPAZ DE SER MELHOR DO QUE JÁ SOU. 
Certamente, as dificuldades de Severino para trabalhar com o caderno agravaram-se pelo fato de interagir pouco com a professora. Ele, muito tímido e reservado, raramente falava com quem quer que fosse. A professora, por sua vez, considerava que as dificuldades de Severino se deviam à falta de interesse e preguiça. Houve sensíveis avanços no desempenho do aluno, nos raros momentos em que a professora acompanhou mais de perto seu trabalho, auxiliando-o com as recomendações necessárias. E foi após esse processo que, ao fim do ano, a professora afirmou que o uso do caderno prejudicou muito as possibilidades de Severino aprender os demais conteúdos da primeira série. Considerava que, se ele pudesse recomeçar a escolarização após ter aprendido a trabalhar com o caderno, certamente teria um desempenho bem melhor.

Severino não foi um dos alunos típicos da sala de aula. Sua trajetória na primeira série, marcada por tão grandes dificuldades, se diferencia da média de alunos. Então, por que esse caso foi apresentado? De que forma Severino pode auxiliar na compreensão de como os alunos de primeira série aprendem a trabalhar com os cadernos?

Por ser um caso extremo, no qual dificuldades relacionadas ao uso dos cadernos escolares se apresentam de modo bastante intenso, Severino auxilia a visualizar em mais cores garridas o que pode ocorrer quando alunos aprendem a trabalhar com cadernos. A ambigüidade e a imprecisão presentes na recorrente frase "façam como está na lousa", repetida diariamente por professores, abre a possibilidade para que os alunos fiquem sem ter parâmetros sobre como devem proceder e acabem incorrendo em erros. As dúvidas sobre em que momentos se deve copiar tal como está na lousa e em quais momentos é possível fazer adaptações também ocorria com os outros alunos da sala, ainda que de maneiras menos paralisadoras. Um exemplo interessante ocorreu em outubro, quando a professora escreveu em um espaço restrito da lousa a seguinte frase, dividida conforme é apresentado a seguir:

\author{
"SOU FELIZ E JESUS \\ ME AMA"
}


A frase deveria ser copiada nos cadernos dos alunos. Por ser curta, caberia em uma única linha até mesmo dos cadernos pequenos. Apesar disso, alguns alunos copiaram tal e qual se apresentava na lousa. João foi um deles. Tão certo estava de que seu modo de realizar a atividade estava correto que, vendo que a colega Catarina tinha feito a cópia toda numa só linha, discutiu com ela.

Outros tipos de confusões foram identificados. Alguns deles diziam respeito mais diretamente aos saberes relacionados à escrita. Considerando-se que os cadernos são a base principal utilizada para o aprendizado e a prática da escrita, os conhecimentos relativos a essa forma de expressão comparecem e se confundem com as dificuldades que os alunos encontram ao utilizar cadernos.

Ao acompanhar o dia-a-dia de uma primeira série, foi possível encontrar casos quase risíveis que não causam surpresa a muitas professoras alfabetizadoras. Patrícia era uma das alunas que realizava a cópia rapidamente. Assim que a professora começava, ela seguia. No entanto, em vez de escrever da esquerda para a direita, escolheu escrever da direita para a esquerda. 0 resultado de cópia do cabeçalho foi:

AICÍRTAP

0002 ED OÇRAM ED 82 AIDNALÔTROH

A situação, ocorrida apenas no início do ano, não perdurou, pois a professora passou a acompanhar de perto o início da realização das atividades de Patrícia. Ao perceber que a aluna começava de modo incorreto, dava indicações de que a cópia devia começar junto à linha da margem esquerda.

Em outra situação, a professora colocou na lousa as letras do alfabeto, uma abaixo da outra. Em seguida, pediu aos alunos que dissessem nomes de animais iniciados com cada uma das letras. Ao final da atividade, a lousa estava repleta; para cada letra foram citados diversos animais. A indicação da professora foi para que os alunos copiassem tudo nos cadernos ${ }^{50}$ :

\footnotetext{
${ }^{50} \mathrm{~A}$ atividade abrangeu todas as letras do alfabeto. Foram selecionadas para apresentação apenas as primeiras linhas do conteúdo da lousa.
} 

A DE ABELHA, ÁGUIA, AVESTRUZ, ARARA, ARANHA
B DE BEIJA-FLOR, BALEIA, BURRO, BOTO, BÚFALO
C DE CABRA, CAVALO, CACHORRO, CABRITO, COBRA
D DE DRAGÃO, DINOSSAURO, DROMEDÁRIO
E DE ELEFANTE, ÉGUA, EMA, ESCORPIÃO

Mateus, um dos alunos, realizou a cópia da seguinte forma ${ }^{51}$ :

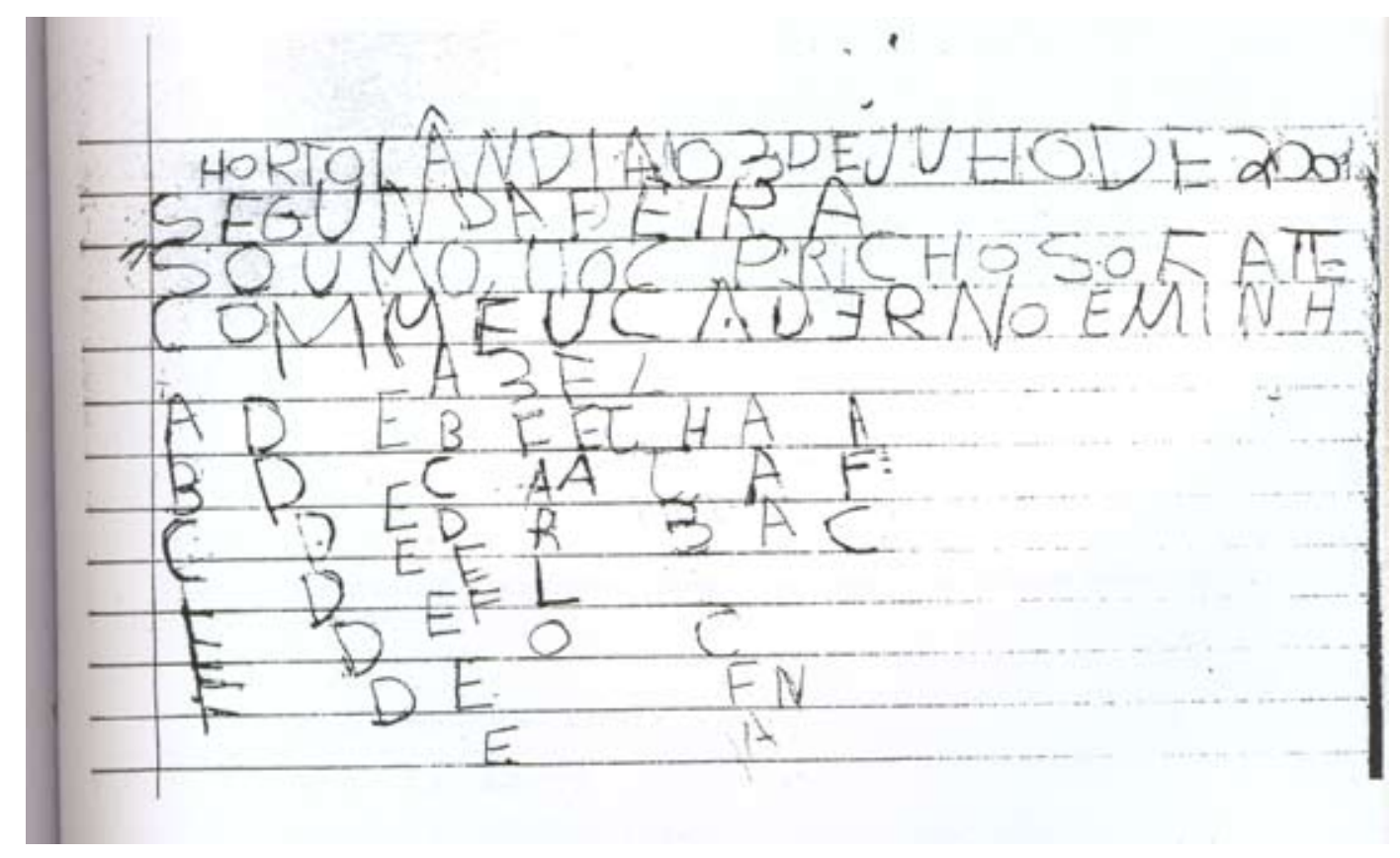

Figura 31. Cópia de Mateus

O resultado caótico e pouco compreensível ocorreu porque Mateus seguiu o procedimento inicial da professora que escreveu as letras do alfabeto na lousa formando uma coluna. Ele passou a copiar buscando colunas no texto apresentado na lousa. Se as letras inicias de cada linha, bem como a palavra 'DE' que aparecia na seqüência, podiam ser copiadas dessa forma sem maiores problemas, o mesmo não acontecia com o texto a seguir. Mateus buscava no texto, apresentado na lousa em linhas, possíveis colunas para copiar. Copiava em colunas que começavam e terminavam ora mais acima, ora mais abaixo. Tal procedimento dificulta a compreensão do resultado

\footnotetext{
${ }^{51}$ A figura acima foi inicialmente apresentada no Capítulo I e agora é retomada à luz do contexto em que foi produzida.
} 
final e torna difícil para alguém que observa o trabalho pronto deduzir qual foi a lógica subjacente à elaboração da cópia.

Mateus desconsiderou uma regra básica da escrita ocidental: escrevemos em linhas. Para Mateus e Patrícia, que se iniciavam nos saberes da língua escrita, ainda não eram claros os preceitos dessa forma de expressão: escreve-se iniciando no lado esquerdo da folha, seguindo para a direita e formando linhas, de cima para baixo. Como utilizavam os cadernos como suporte, foi nesses materiais que as dificuldades se manifestaram.

Às voltas com o aprendizado da escrita e seus suportes, os alunos ficavam sujeitados a buscar proceder tal como era o esperado pela escola. Poucos foram os alunos da primeira série por mim acompanhada que puderam ir além disso e fazer da possibilidade de registrar nos cadernos uma forma de expressão criativa. Eduardo foi um aluno que utilizou caderno de modo peculiar e bastante pessoal. Um dos melhores alunos da sala, Eduardo chegou ao final do ano com bom domínio da leitura e da escrita. Era capaz de ler e compreender os livros disponíveis na sala de aula e escrevia pequenos textos, cometendo apenas erros ortográficos. Demonstrava grande familiaridade com o caderno e com as regras para seu uso. Utilizava as folhas seguindo corretamente a sequiência temporal, sem deixar folhas incompletas ou em branco; em geral, tomava decisões corretas a respeito de quando era necessário, ou não, deixar linhas em branco em seu caderno. Ao copiar da lousa, conseguia distinguir quando era necessário seguir fielmente a divisão em linhas, feita pela professora no quadro negro, e quando era possível adequar a cópia ao tamanho da linha de seu caderno.

O que mais chamava a atenção no modo de proceder de Eduardo era a possibilidade que ele encontrava de fazer do caderno um espaço com significações que transcendiam as estritamente escolares. Em uma das aulas, próxima ao final do ano, Eduardo escreveu na contracapa de seu caderno o nome de todos os que estavam na sala de aula: alunos, professora e até a pesquisadora. la olhando para a sala e anotando, um a um. Conversei com ele a respeito: 
P: Pra que vai servir fazer assim?

E: Quando, quando eu tiver... Quando eu sair da escola, pra eu lembrar deles.

P: Ah. O que você vai fazer com esse caderno quando você sair da escola?

E: Vou guardar ele.

P: Vai guardar. E como você vai fazer para lembrar dos seus colegas?

E: Está escrito aqui, eu lembro o nome deles.

P: Você vai olhar? (Ele acena afirmativamente com a cabeça.) Onde você vai guardar?

E: No meu guarda-roupa. Quando eu sentir saudade... (ele continua escrevendo o nome de um colega dizendo em voz alta as letras) (...) P: E quando você guardar seu caderno lá no guarda-roupa, você vai olhar ele pra mais alguma coisa, além de você lembrar dos seus colegas?

E: Vou... Posso lembrar do que eu escrevi.

P: Hum...

E: Lembrar o que eu aprendi... Aqui está o nome da minha namorada, sabe? (Eduardo mostra algo que eu já havia visto em outra ocasião: há o nome de uma menina da sala e uma declaração de amor)

P: Ah, mas... É aqui da sala?

E: É. (resposta rápida)

P: Está aí?

E: Está ali. (Eduardo indica que ela está um pouco atrás de nós)

$P$ : Ela sabe que é sua namorada? (ele estala a língua em sinal negativo) Não?

Eduardo continua escrevendo o nome de alguns colegas, sempre falando em voz alta os nomes: Jéssica, Angélica...

E: É bem legal lembrar dos amigos, né?

$\mathrm{P}: \mathrm{O}$ quê?

E: É legal lembrar dos amigos.

$P$ : Eu acho que é bem legal lembrar.

E: Jéssica... (continua escrevendo os nomes dos colegas)

(Trecho de anotação realizada em campo)

Eduardo se utilizava do caderno e da escrita, ou seja, dos recursos escolares para fins pessoais. Assim, registrava para poder se lembrar, fazia escolhas a respeito do que gostaria de recordar. Anotou o nome de todos os seus colegas, mas deu maior destaque à menina por quem tinha especial afeto. Era uma utilização diferente da que podiam fazer muitos de seus colegas, para quem os cadernos eram apenas suportes para a exercitação de conteúdos escolares, cenários para fracassos e sucessos, que nem sempre lhes eram inteligíveis. Eduardo compreendia o que era possível fazer nos cadernos seguindo os preceitos escolares e ia além. Utilizava-os de modo pessoal e autoral. 
Eduardo era uma exceção. A maioria dos alunos enfrentou, durante boa parte do ano, dificuldades para realizar os registros. Os empecilhos encontrados por muitos alunos no trabalho com os cadernos faziam com que a professora tomasse algumas medidas tanto para auxiliar os alunos a superar o que faziam em desacordo com o esperado, quanto para minimizar o impacto que as dificuldades tinham sobre o andamento das atividades da sala.

Uma das medidas era o uso de folhas mimeografadas previamente preparadas com o enunciado de exercícios, materiais chamados de folhinhas. Assim, restava aos alunos resolver o que era proposto e, ao final, colar a folhinha no caderno. Ao restringir a dimensão da atividade proposta, as diferenças de ritmos entre os alunos da sala tornavam-se menos significativas, o que auxiliava a professora a desenvolver o trabalho didático. A estratégia foi mais utilizada no primeiro semestre, quando havia dias em que a única atividade elaborada pelos alunos diretamente sobre as folhas dos cadernos era a cópia do cabeçalho. À medida que a escrita se tornou menos penosa, diminuiu o uso das folhinhas.

Outras medidas utilizadas para auxiliar os alunos se davam por meio da interação entre a professora e os alunos. As instruções para o uso dos cadernos eram dadas à medida que as dificuldades se apresentavam. Eram comuns as instruções verbais como da professora no caso descrito da aluna Patrícia, que escrevia da direita para a esquerda. Outras vezes, indicações gráficas eram usadas como complementação. Horácio, por exemplo, era um aluno que costumava fazer as tarefas dispersas nas várias páginas do caderno, sem respeitar a sequiência proposta pela professora. Em uma das aulas:

Ana veio até Horácio e disse: “Vamos lá, Horácio, organizar este caderno." Procura pela borracha dele, não encontra. Ana vai buscar uma borracha e continua a dar orientações: "Horácio, tem que ser aqui." Ana faz um $X$ no início da linha onde Horácio deve começar a copiar."

(Trecho de anotação realizada em campo) 
É importante destacar que os alunos que buscavam mais o contato com a professora ao longo da aula, querendo mostrar suas produções para que fossem avaliadas, criavam maiores possibilidades de receber indicações sobre como proceder de acordo com o esperado. No caso dos alunos mais reservados e que interagiam menos com a professora, como nos casos de Mateus e Severino, as dificuldades costumavam se prolongar por mais tempo, aparecendo em diversas atividades.

Outro procedimento usado pela professora para que os alunos trabalhassem em seus cadernos de acordo com o esperado consistia na redação de bilhetes. Os bilhetes eram, em sua maioria, direcionados aos pais - ou mais especificamente às mães. Relatavam algum problema e, de modo direto ou indireto, solicitavam aos pais que tomassem providências:

Mãe, a Catarina não está fazendo suas lições direito, não tem feito a lição de casa, seu caderno não tem capricho, fica brincando o tempo todo, arruma confusão com os colegas e não me obedece, ela precisa mudar seu comportamento urgente. Ana

(Texto de bilhete encontrado no caderno de Catarina)

Os bilhetes eram indecifráveis para a maioria dos alunos, dado que se encontravam em processo de alfabetização. Enquanto eram alfabetizados em letra de forma, os bilhetes eram redigidos em letra manuscrita. Ainda que os alunos não soubessem o que continham, os bilhetes eram muito temidos e indesejados. Não era raro que resultassem em sérias punições por parte da família, como aparece na seguinte comunicação entre escola e família ${ }^{52}$ :

Mãe,

A Sueli não está fazendo suas lições, seu caderno está uma bagunça. Não fez a lição de casa e fica brincando na hora que deveria fazer a lição.

Ana

52 Souza, Lima e Braga (2001) realizaram importante pesquisa de iniciação científica, demonstrando que grande parte da violência doméstica contra a criança tem sua origem no fracasso nos primeiros anos de escolaridade. 
Shra Professora

Eu não sei que lição é essa do filme que ela assistiu, eu não assisti. Se ela não sabe eu é que não sei.

Ela vai apanhar aqui hoje por isso, é a shra. pode ficar brava com ela pega no pé dela não dá moleza não.

Obrigada

Silvia

(Texto de bilhete e resposta escrita pela mãe encontrados no caderno de Sueli)

Mais raramente, havia bilhetes dirigidos aos próprios alunos, solicitando que modificassem algo na sua forma de proceder. Por exemplo: “cuidado para não pular a folha", ou "precisa melhorar a letra”. Apesar de serem em menor número, também havia elogios escritos pela professora.

Algo se configurou nessa sala de aula que parece ser bastante significativo: o fato de a professora escrever algo nos cadernos passou a ser visto como absolutamente negativo pelos alunos. Incapazes de ler, sempre diziam, quando questionados a respeito do conteúdo dos bilhetes, que essas comunicações denunciavam alguma falha cometida. Foi o caso, por exemplo, de Mateus. Folheando seu caderno, encontrei um bilhete escrito pela professora que comunicava à mãe do aluno que Mateus tinha se machucado na escola. Perguntei a ele o que estava escrito ali e ele me disse: "não fez lição".

Assim, entre erros e acertos, entre esforços imensos e momentos de desistência, entre regras aprendidas e regras mal compreendidas, entre lances de sorte e outros de azar, os alunos vão se apropriando do modo que a escola propõe para a utilização dos cadernos. Para alguns alunos, esse processo implica grande sofrimento. Ao elaborar seus registros diários, vivenciam repetidos insucessos e, assim, passam a acreditar pouco em suas potencialidades como estudantes. Não encontram brechas para expressões pessoais nesses materiais escolares que os acompanham.

Para outros alunos, a elaboração dos registros são momentos que apresentam obstáculos que, com alguma ajuda, podem ser superados. A atuação da professora apontando erros e indicando o procedimento correto pode ser decisiva.

Apenas alguns alunos passam por essa etapa de modo mais ameno, chegando a conseguir fazer de seus cadernos espaços de criação. Utilizações pouco freqüentes 
nessa etapa da escolarização, tais como apresentou Eduardo, podem ser definidas como ações táticas. Certau (2005) caracterizou as táticas como formas de ação possíveis àquele que é mais fraco, que não pode organizar ou modificar as regras do espaço onde se movimenta. São possibilidades de imprimir marcas pessoais a espaços que têm seu uso previsto pela escola, são momentos criativos que possibilitam uma ressignificação dos suportes de registro.

O que surge como um fato esporádico no início da escolarização passa a compor o modo de estar na escola dos alunos mais experientes. Vejamos agora como se configurou tal aspecto no fim do primeiro ciclo do ensino fundamental.

\section{IV.2 QUARTA SÉRIE: AMPLIAM-SE AS POSSIBILIDADES DE CRIAÇÃO}

Como vimos, na quarta série acompanhada por mim, um contexto bastante diferenciado em relação ao uso dos cadernos se delineou. A maioria dos alunos conhecia com clareza as nuances das regras de uso dos cadernos. Em vez de arriscarem formas que supunham ser as mais adequadas de proceder, oscilavam entre cumprir as regras e desrespeitá-las. No lugar da ingenuidade e do desconhecimento, ganhava espaço a possibilidade de fazer opções.

As cópias de enunciados e pequenos textos não chegavam a ser procedimentos excessivamente morosos; eram apenas tarefas necessárias para o cumprimento das demais atividades propostas.

As folhinhas continuavam sendo usadas, porém em situações mais específicas, não mais por causa das dificuldades dos alunos em utilizar os cadernos, mas para possibilitar alguma comodidade à professora. Como, por exemplo, quando as atividades seriam corrigidas fora da escola. Assim, em vez de transportar 30 ou mais cadernos, bastava carregar um maço de folhas. Raramente, a intenção de tornar o trabalho mais dinâmico mobilizava esse tipo de procedimento. 
Os bilhetes continuaram sendo um recurso bastante utilizado pelos professores para garantir que os alunos realizassem as tarefas e se comportassem de modo considerado disciplinado. Freqüentes desencadeadores de punições familiares, continuavam sendo temidos pelos alunos. No entanto, se na primeira série o fato de um professor escrever no caderno é visto pelo aluno como algo que necessariamente denuncia que foi feita alguma coisa negativa, na quarta série isso muda. Os alunos, em sua maioria capazes de conhecer o significado das comunicações feitas pelos professores, passavam a demonstrar maior gosto pelo fato de o professor escrever em suas produções. Eram freqüentes, até mesmo, as imitações do modo de correção e da letra da professora.

Na primeira série, o conteúdo dos cadernos se restringia às cópias e à resolução de exercícios que previam respostas simples - ainda que não necessariamente fáceis para os alunos - e, quase sempre, únicas. As produções mais livres, que abriam a possibilidade para que os alunos respondessem de formas mais diferenciadas, restringiam-se à formação de frases simples. Na quarta série, ampliava-se esse formato de atividade que solicita dos alunos a produção de textos com base em reflexões, opiniões, experiências e desejos. 0 conteúdo dos cadernos torna-se mais autoral, como vimos no capítulo anterior.

Certamente, a familiaridade e o domínio da língua escrita abriam inúmeras possibilidades para que os alunos dessem aos cadernos conteúdos mais pessoais e diferenciados. Além de produzirem textos, ao saberem ler e escrever, os alunos podiam, ainda, tomar decisões de modo embasado sobre como deviam proceder em relação aos seus cadernos. Em vez de copiarem uma série de palavras e frases cuja significação desconheciam, os alunos passavam a reconhecer as informações, sabendo que eram, por exemplo, textos didáticos ou enunciados de exercícios. Faziam opções estéticas que, em geral, não prejudicavam a compreensão do conteúdo.

Observando os exemplos de Eduardo e dos diversos alunos da quarta série, seria possível concluir que o domínio da escrita exerceu papel determinante na conquista dessa autonomia. Jordan, um dos alunos que mais tiveram dificuldades diante dos conteúdos desenvolvidos na quarta série, pode trazer nuances desse processo. Ele foi 
um dos poucos reprovados ao fim desse ano de escolarização, pois estava numa etapa da alfabetização pouco compatível com as atividades da quarta série. Apesar de ter evoluído bastante ao longo do ano, os textos por ele produzidos próximo ao final do ano ainda eram de difícil entendimento para o leitor. 0 texto abaixo foi produzido por ele. Em busca de avaliar em que nível de aprendizado de leitura e escrita estava Jordan, a professora solicitou que ele lesse para ela o que tinha escrito. Foi assim que obteve o conteúdo transcrito, que aparece abaixo do texto original:

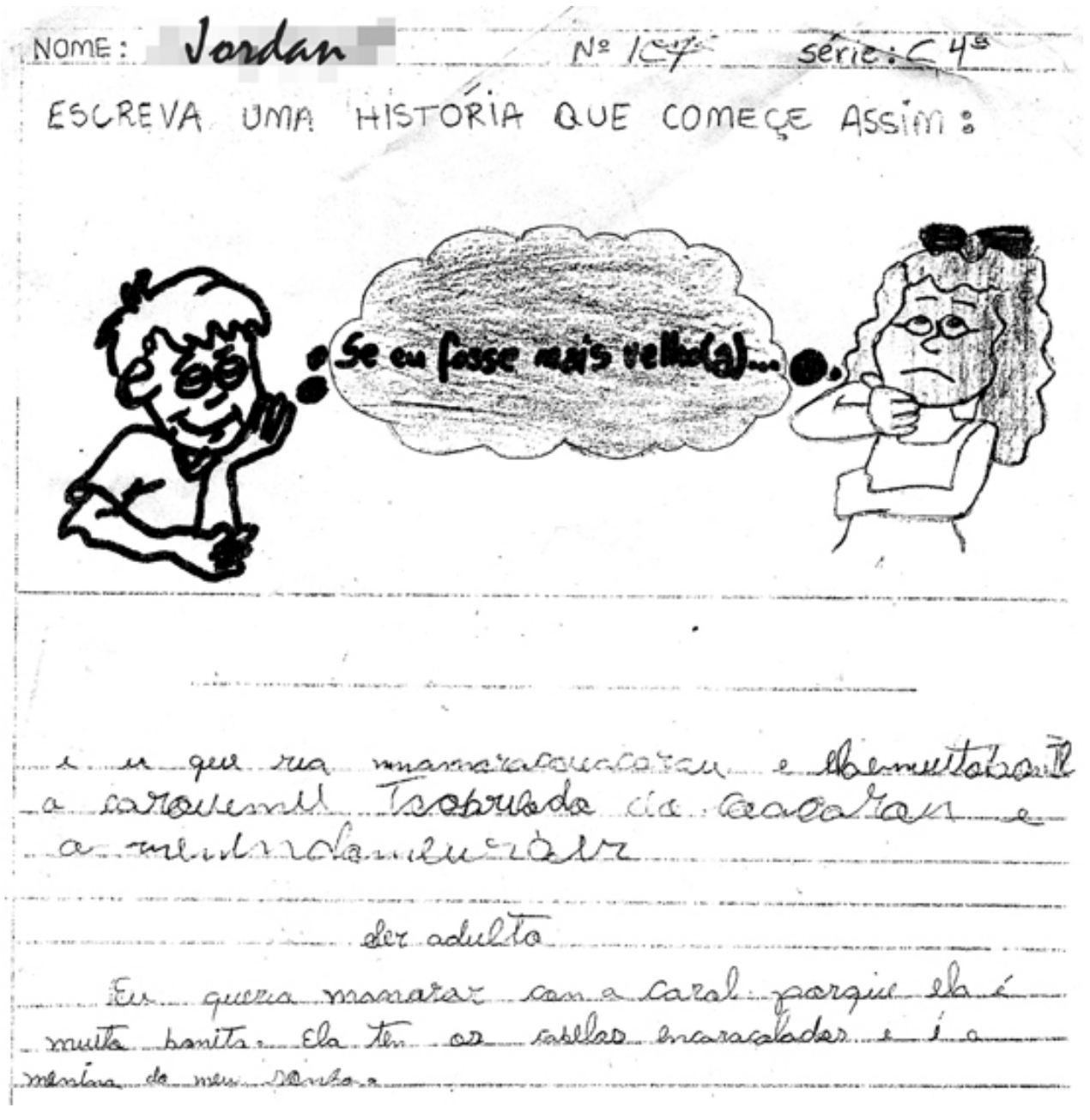

Figura 32. Produção de texto de Jordan com transcrição feita pela professora $^{53}$

\footnotetext{
53 Transcrição do texto produzido por Jordan anotada na folhinha pela professora:

Ser adulto

Eu queria namorar com a Carol porque ela é muito bonita. Ela tem os cabelos encaracolados e é a menina do meu sonho.
} 
É possível pela transcrição identificar a maioria das palavras. No entanto, os erros e a forma utilizada para separar as palavras comprometiam bastante a possibilidade de que Jordan comunicasse por escrito o que pretendia. Jordan também tinha muitas dificuldades para compreender conteúdos escritos.

Ainda assim, o aluno mostrava muita familiaridade com o uso dos cadernos, conhecendo profundamente suas regras de utilização, algo que expunha verbalmente, em especial, quando fazia comentários a respeito do caderno que eu utilizava para fazer minhas anotações de campo. Certa vez, percebendo que meu caderno estava desorganizado, com anotações que extrapolavam o tamanho das linhas e com várias palavras riscadas, Jordan insistiu em que eu usasse o corretivo líquido - chamado por ele de "branquinho". Outra vez, percebeu que mudei de linha antes que esta acabasse e sem usar ponto final. Ele se aproximou de mim e comentou que era estranho fazer aquilo. Perguntei se podia fazer desse modo e ele disse que, se eu quisesse, sim, acrescentando: "Pode, cada pessoa tem seu gosto". Quando perguntei como ele fazia, disse: "vou escrevendo até terminar a linha".

Jordan demonstrava dominar as normas de uso do caderno. Expressava ainda mais sua familiaridade ao comentar que as regras não são rígidas e podem ser flexibilizadas, em muitos momentos, segundo as preferências daquele que escreve. Ou seja, mesmo não estando alfabetizado, Jordan era capaz de utilizar os cadernos de modo adequado. Os três primeiros anos de uso dos cadernos garantiram-lhe a familiaridade necessária com as regras escolares de utilização dos suportes de escrita. Ao dominar essa "tecnologia" ${ }^{54}$, Jordan ganhava autonomia. Mesmo que a escrita ainda não the oferecesse tantas possibilidades de autoria, o aluno criava nos modos de utilizar o caderno. Primava pelo conforto ao escrever e, sendo assim, não utilizava as últimas linhas de cada folha:

${ }^{54}$ Oliveira (2002) usa a expressão "tecnologia" para referir-se aos cadernos, objetos que, quando começaram a ser utilizados, desencadearam inúmeras transformações no espaço escolar. 
“Machuca a mão escrever na última linha”

Também não gostava de usar o verso da folha:

Estou escrevendo na última linha de uma folha e Jordan me pergunta:
"O que você vai fazer quando acabar a folha?". Explico que vou virar e
continuar na outra. Ele me explica que não escreve nunca nas costas
da folha. Pergunto o porquê e ele explica que escreve forte, então
não gosta de escrever na parte de trás da folha. "Eu tento escrever
tudo nessa." (RA-03)

Em relação aos conhecimentos de leitura e escrita, Jordan equiparava-se a muitos dos alunos da primeira série, mas conhecedor das regras da escola e do uso dos cadernos, encontrava brechas para fazer utilizações pessoais. A professora não apreciava as escolhas de Jordan para o uso dos cadernos, contudo tolerava que ele assim fizesse.

Logo, o fato de conhecer as regras não faz dos alunos, de forma alguma, grandes cumpridores daquilo que é proposto. Diferentemente dos alunos iniciantes que freqüentemente desrespeitam as normas por desconhecimento, os alunos da quarta série usam-nas com astúcia. Fazem do conhecimento que possuem um recurso para fazer operações próprias, para deixar marcas nos objetos e espaços da escola. Como aponta Certau (2005), os indivíduos constroem modos de proceder que compõem uma rede de antidisciplina. Conhecer a maneira pela qual a escola propõe o uso dos cadernos dá aos alunos as informações necessárias para que eles, de modos diferenciados, encontrem formas para transgredir. Tais formas seguem caminhos imprevisíveis pela escola.

Ralph era um dos alunos da sala de aula que pode nos auxiliar a compreender esse processo. Ele gostava muito de fazer desenhos. A ação de decorar os cadernos não era malvista na sala de aula, e, assim, seus cadernos tinham desenhos de tipos variados: heróis de desenhos animados, animais e paisagens. Havia também outra categoria de desenhos, bastante exercitada por Ralph e pouco bem-vista na escola: os desenhos de 
cunho sexual. Com 12 anos, Ralph vivia o início da adolescência bastante mobilizado por tudo aquilo que se referisse à sexualidade. Desenhos de pênis, nádegas e corpos de mulheres nuas podiam ser encontrados nos seus cadernos escolares.

No entanto, o modo pelo qual Ralph dispunha seus desenhos nos cadernos revelava sua familiaridade com as regras - claramente expressas ou tácitas - de utilização dos cadernos. Os desenhos permitidos pela escola eram feitos em lugares que sabidamente seriam mais facilmente vistos pela professora: ao final das atividades propostas ou nas páginas subseqüentes que seriam ocupadas nos próximos dias. Diferentemente, os desenhos que podiam ser malvistos eram feitos nos espaços menos expostos: as últimas folhas do caderno, ou folhas ocupadas anteriormente por atividades, devidamente verificadas e corrigidas pela professora. Assim, Ralph transgredia as regras vigentes na sala de aula, assumindo os conhecidos riscos a que estava sujeito de ser repreendido e castigado. Resguardava-se, porém, usando com habilidade subterfúgios que minimizavam as probabilidades de ser descoberto.

Durante o tempo que passei em campo, pedi a alguns alunos que me emprestassem ou dessem cadernos. Certo dia, Ralph me prometeu um caderno seu. Logo depois que conversamos, percebi que ele arrancou várias folhas de seu caderno, fazendo com elas uma bola grande, aproximadamente do tamanho de um melão. Guardou as folhas arrancadas na mochila e me entregou o que restou do caderno. Quando perguntei a razão de ter tirado as folhas, Ralph disse: “as folhas que eu tirei, é que tinham desenho sujo". A resposta demonstra que ele não só sabia que tais desenhos não eram aceitos na escola, mas que também não devia ser adequado mostrá-los à pesquisadora. No entanto, uma figura ${ }^{55}$ de um menino nu permaneceu. Um pênis bastante detalhado e evidente contrastava com o traçado simplificado do desenho.

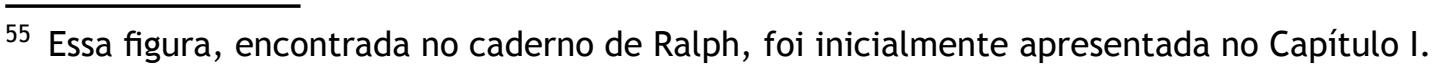




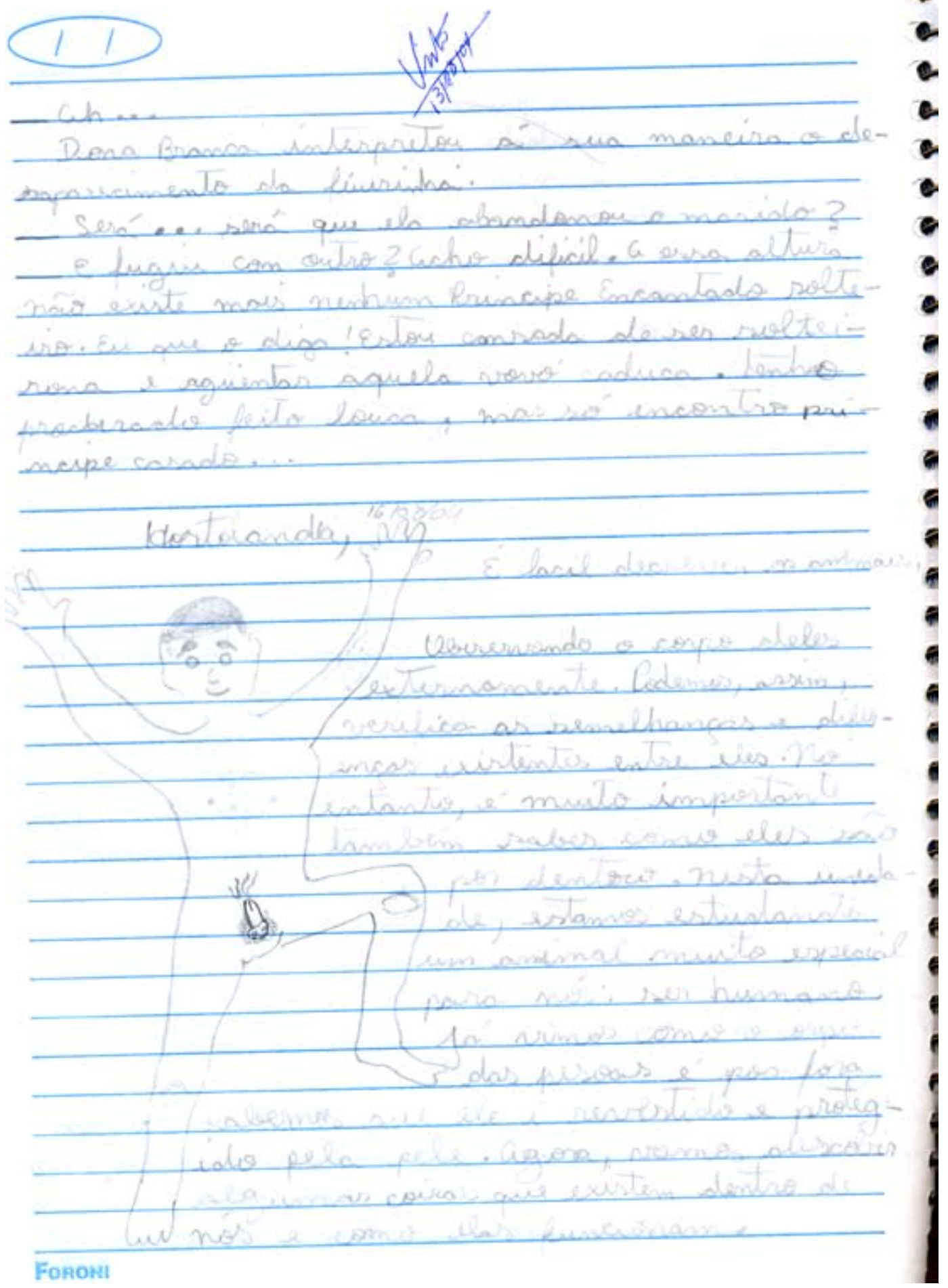

Figura 33. Cópia e desenho no caderno de Ralph ${ }^{56}$

56 Hortolândia, 16/08/04

É fácil descrever os animais observando o corpo deles externamente. Podemos, assim, verificar as semelhanças e diferenças existentes entre eles. No entanto, é muito importante também saber como eles são por dentro. Nesta unidade, estamos estudando um animal muito especial para nós: ser humano. Já vimos como o corpo das pessoas é por fora, sabemos que ele é revestido e protegido pela pele. Agora, vamos descobrir algumas coisas que existem dentro de nós e como elas funcionam. 
Tratava-se da ilustração da cópia de um texto que falava sobre o corpo humano. E, nesse caso específico, o desenho de um pênis era pertinente ao conteúdo abordado. Aliás, foi sabendo disso que Ralph o fez e o mostrou à professora que, naquela circunstância, recebeu o desenho com aprovação. E também foi por saber que esse seria um desenho permitido que ele deixou no caderno após o processo de censura ao qual submeteu sua produção.

Chama a atenção o modo extremamente hábil que o aluno encontra para fazer com que aquilo que corriqueiramente é condenado na escola possa ser bem aceito, ainda que de maneira circunscrita. Assim como Eduardo e Jordan, Ralph utiliza-se de uma tática:

As táticas são procedimentos que valem pela pertinência que dão (...) às circunstâncias que o instante preciso de uma intervenção transforma em situação favorável. (CERTAU, 2005, p. 102)

Dessa forma, Ralph e seus colegas se aproveitavam de circunstâncias para subverter a ordem estabelecida. Percebiam brechas nas quais podiam agir e, com astúcia, livravam-se, ou minimizavam castigos e repreensões.

À medida que os alunos se apropriavam das normas vigentes na escola para o uso dos cadernos, podiam fazer escolhas de procedimentos dentro do que thes era permitido, ou tolerado. Vislumbravam formas variadas de modos de proceder e faziam escolhas em uma gama de possibilidades. Também era a intimidade com as regras estabelecidas que thes permitia encontrar caminhos para burlá-las, flexibilizálas ou, simplesmente, transgredi-las.

O domínio das regras vigentes na escola, da leitura e da escrita amplia as possibilidades de autoria, fazendo com que os cadernos possam ser espaços de criação e subversão do que é imposto. As transgressões dos alunos podem ser entendidas como tendo potenciais emancipatórios, pois abrem a possibilidade de que os alunos não fiquem subjugados aos usos que a escola prevê. Surgem as infinitas possibilidades de uso dos cadernos (OLIVEIRA, 2002), que recebem declarações de amor e de amizade, 
desenhos, anotações, letras de músicas. Por vezes, prestam-se a mediar uma discreta conversa por escrito. Outras vezes, viram matéria-prima para fazer bolinhas que serão arremessadas nos colegas. Ou seja, servem a uma infinidade de coisas que não seria possível abranger.

Certau (2005) descreve como os jogos, os contos e as lendas funcionam como espaços nos quais é possível ensaiar táticas e esquemas de ação que poderiam ser utilizados no sistema social. Também na prática cotidiana de fazer registros são ensaiadas pequenas transformações:

0 reconhecimento do papel fundamental dos fazeres da vida cotidiana e das novidades que eles são capazes de criar na tessitura da emancipação social nos permite supor que é também nesses espaços que tecemos o futuro, a partir do presente. Por meio dos usos cotidianos que cedemos às regras estabelecidas que possibilitam desde aquilo que se refere ao consumo dos produtos mais banais, até aquilo que diz respeito à recriação dos modelos de comportamento social que nos chegam como "leis", nossas astúcias cotidianas tecem nossas utopias. (OLIVEIRA, 2002, p.40)

E dessa forma, é no uso cotidiano dos cadernos e demais suportes de registros que são criadas, por alunos, pais e professores, as possibilidades de novos usos. É no dia-a-dia das escolas que se dá a reinvenção dessas tecnologias. 


\section{CADERNOS FRANCESES}

\section{V.1 “ESSE É UM CADERNO DE RASCUNHO?”}

A minha ida à França, para conhecer o modo pelo qual os franceses utilizavam os cadernos escolares, só foi possível pela disponibilidade da pesquisadora AnneMarie Chartier, que vem estudando o assunto há alguns anos.

Quando nos encontramos pela primeira vez, ela me pediu que eu the mostrasse um caderno brasileiro. Levei um dos cadernos que tinha recolhido durante minhas pesquisas de campo. Escolhi um dos melhores que tinha em meu poder: um caderno preenchido em sua totalidade, repleto de atividades, cópias, bem decorado. Após folhear o caderno, Anne-Marie me perguntou: “Esse é um caderno de rascunho?".

Quando vi, pela primeira vez, um caderno de um aluno francês, surpreendeume especialmente a apresentação: muito organizado, a letra traçada com capricho. Parecia-me um caderno impecável, preenchido com um raro grau de esmero.

As primeiras impressões que tivemos - Anne-Marie sobre o caderno brasileiro e eu sobre o caderno francês - são bastante significativas. São impressões baseadas nas expectativas que construímos, baseadas em nossos referenciais, sobre como são os cadernos escolares. Foi com base no modo pelo qual os franceses preenchem os seus cadernos - com conteúdos escolares registrados a caneta de forma bastante organizada - que o caderno brasileiro pareceu à pesquisadora francesa um caderno de rascunho. Foi baseada na cultura escolar brasileira, bastante tolerante em relação a formas personalizadas de uso dos cadernos, que o caderno francês me pareceu excessivamente ordenado.

Certamente, há muitas características comuns no modo de apresentação dos cadernos das duas nacionalidades. Prova disso é que tanto eu quanto Anne-Marie fomos capazes de reconhecer os suportes de registros alheios às nossas culturas como cadernos escolares. Mantêm-se o uso de cabeçalho, os enunciados de exercícios 
seguidos de resoluções, as correções feitas pelos professores, entre outros aspectos. Ainda que, possivelmente, as semelhanças sejam maiores que as diferenças, apresentarei a seguir aspectos que, por serem díspares, trazem a possibilidade de questionarmos o que entendemos como incontestável e natural.

\section{V.2 ALGUMAS INFORMAÇÕES SOBRE O CONTEXTO DE ENSINO FRANCÊS}

Conforme apontado anteriormente, não há a pretensão de apresentar uma completa descrição das características do sistema educacional público na França. Pretendo apenas trazer informações, recolhidas em escolas elementares públicas francesas, que possam auxiliar na compreensão de como os cadernos franceses se inserem em tal contexto e como são utilizados.

As aulas acontecem às segundas, terças, quintas, sextas e sábados, ou seja, as quartas-feiras e os domingos são dedicados a pausas. Durante a semana, as aulas se dão em período integral, totalizando 6 horas de aulas por dia ${ }^{57}$. Os alunos chegam pela manhã e, após cerca de uma hora e meia, têm uma pausa para recreação. Há outra pausa, um pouco mais longa, para o almoço. Alguns dos alunos permanecem na própria escola, outros voltam para suas residências para almoçar. As aulas são retomadas no período da tarde, que também tem uma pausa de recreação. Aos sábados, as aulas acontecem apenas pela manhã, com uma única pausa.

A organização das aulas em período integral tem algumas implicações no modo pelo qual se organizam as escolas, os professores e suas práticas. Primeiramente, um professor tem, a cada ano, uma única classe, podendo centrar o seu trabalho nas necessidades de um único grupo. Fisicamente, pode contar com uma sala de aula apenas para si, organizar o espaço de acordo com o planejamento de sua aula e, até mesmo, manter anotações na lousa para retomá-las em outro momento. Outra possibilidade que se amplia com o uso exclusivo da sala - e que os professores franceses

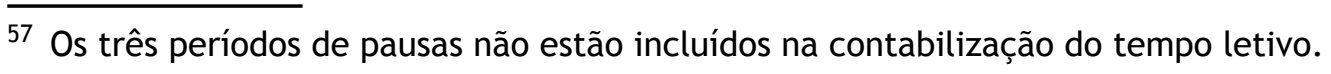


que conheci utilizavam em profusão - é a utilização das paredes para a afixação de produções dos alunos e de recursos auxiliares do ensino, tais como alfabeto, listas de palavras, letras de músicas, mapas, linhas do tempo, entre outros.

Cada aluno possui uma carteira utilizada somente por ele. Dessa forma, muitos materiais podem ser deixados na escola e somente o que será utilizado em casa é transportado. Algo que compõe uma situação com várias diferenças em relação àquilo que se observa nas escolas brasileiras: os alunos possuem maior quantidade de materiais, as atividades realizadas na escola transitam com menor freqüência nas casas dos alunos, as condições fornecidas de armazenamento possibilitam que os livros e cadernos sejam menos manuseados e, assim, podem ser mais bem conservados.

O professor não trabalhava só. Havia, em cada escola, alguns professores auxiliares. Eram eles que assessoravam os professores de cada sala de aula em determinados momentos, trabalhando com parte dos alunos ou com a totalidade da classe. Dessa maneira, o professor, apesar de trabalhar em tempo integral, tinha momentos em que podia desenvolver atividades sem a presença dos alunos, tais como preparar aulas, corrigir atividades ou, até mesmo, fazer cursos que complementassem sua formação. Em outros momentos, o professor auxiliar desenvolvia atividades com parte da sala de aula, algo que possibilitava o desenvolvimento de atividades mais adequadas a grupos de menores dimensões.

Não somente em relação à quantidade de profissionais se identifica a riqueza das escolas francesas das ZEPs. Também em relação aos recursos materiais há diferenças consideráveis, quando se toma a realidade das escolas públicas brasileiras como referência. Isso se torna visível não só pela presença de equipamentos caros, tais como filmadoras, máquinas fotográficas digitais, aparelhos de som, computadores, freqüentemente disponíveis na própria sala de aula; mas também pela disponibilidade oferecida pela escola de materiais bem mais acessíveis. Por exemplo, em cada sala de aula havia um conjunto de materiais de uso comum, que poderiam ser usados, durante o transcorrer das aulas, por qualquer aluno que deles necessitasse. Lápis 
pretos e coloridos, giz de cera, canetinhas, borrachas, ardoises $^{58}$, tesouras e outros materiais podem ser trazidos de casa, ou, em caso de esquecimento ou falta de recursos da família para adquiri-los, estão disponíveis para que os alunos os utilizem a fim de realizar as atividades. Apesar de poucas movimentações serem permitidas aos alunos, durante a realização das atividades, o acesso à mesa de materiais de uso comum era livre. Ao aluno que sentisse falta de algo bastava levantar-se para pegar. Devolver ao final da utilização era uma condição necessária.

As bibliotecas de sala de aula também eram freqüentes e utilizadas como importante material de apoio para a alfabetização e para ocupar os alunos que terminavam primeiro suas atividades.

O que parece a alguém acostumado às escolas públicas brasileiras uma abundância de recursos não soa assim aos franceses. Pude presenciar algumas atitudes de professores organizando-se para conseguir incrementar tal acervo de materiais.

A presença e a disponibilidade de tais recursos não são, em si, sinônimos de uma educação de alta qualidade. É inegável, porém, que as condições materiais auxiliam no desenvolvimento do trabalho pedagógico, incluindo alternativas e possibilitando a utilização de maior diversidade de estratégias. A previsão de que uma parte do tempo de serviço do professor será dedicada ao planejamento de atividades, à correção dos trabalhos dos alunos e à formação continuada garante uma série de condições fundamentais ao desenvolvimento de um bom trabalho. 0 fato de a escola fornecer aos alunos, sem necessidades de justificativas ou constrangimentos, os recursos materiais necessários para a realização das atividades trazia um respaldo muito importante para a realização das atividades escolares. Tal medida reduzia um problema recorrente nas escolas brasileiras, que é o custo imposto às famílias para manter suas crianças estudando, ainda que a educação seja fornecida pelo Estado 59 .

\footnotetext{
58 Pequenas lousas brancas ou verdes individuais utilizadas para realizar exercícios, em especial de matemática.

59 Campos e Goldstein (1981) introduzem essa discussão no Brasil, no início dos anos 1980, ao analisar, do ponto de vista da Sociologia da Educação, o fato de que os pais das camadas populares têm apreço pela escola e o quanto a escola para essa população, embora pública, não é gratuita.
} 
Os cadernos escolares estão entre os materiais que são fornecidos aos alunos. São fornecidos vários exemplares que se diferenciam pela cor da capa, pelo tamanho e pela configuração das páginas. No caso parisiense, as capas têm as inscrições “Mairie de Paris"60 e "fournitures scolaires gratuites"61 e um espaço reservado para que os alunos coloquem o nome da disciplina a que se refere o caderno, seus nomes e salas. As características desses cadernos serão mais cuidadosamente descritas a seguir.

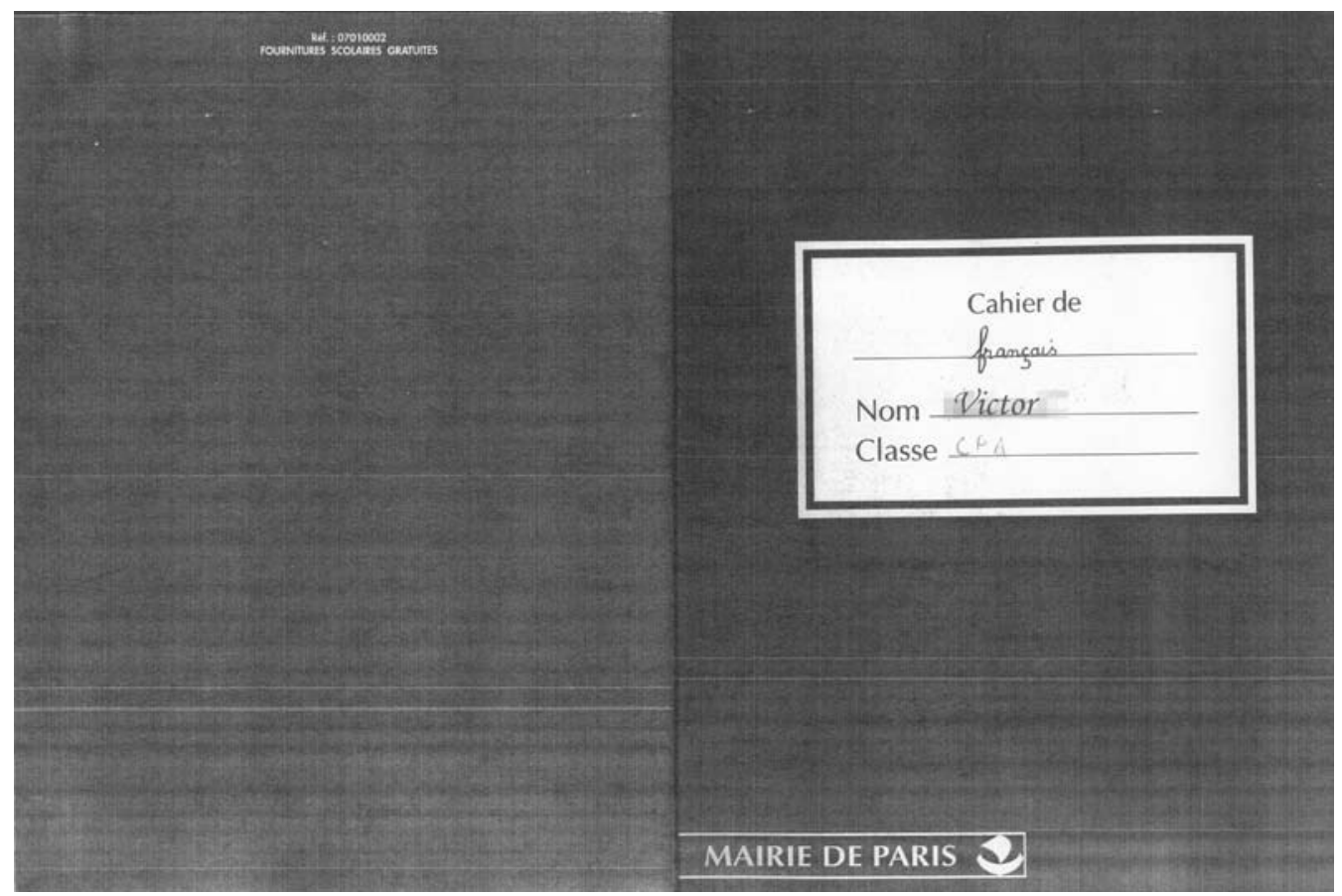

Figura 34. Capa de caderno fornecido pela Mairie de Paris

No geral, vigora nas escolas francesas algo que, para o olhar de uma pesquisadora do Brasil, pode ser considerado uma rígida disciplina. As salas são bastante silenciosas, os alunos pouco se levantam durante as aulas. Atos que se afastem, ainda que ligeiramente, daquilo que é considerado o modo correto de proceder como aluno são repreendidos de modo vigoroso pelos professores. Certamente, os cadernos não estão fora desse cenário e o trabalho diário sobre esses suportes de escrita é marcado por uma série de rígidas regras que serão descritas mais detalhadamente ao longo deste capítulo.

\footnotetext{
60 Mairie é o equivalente à Prefeitura no Brasil.

61 Fournitures scolaires gratuites significa, em português, fornecimento escolar gratuito.
} 


\section{V.3 OS CADERNOS COMO OBJETOS}

O modo pelo qual os cadernos franceses se apresentam difere materialmente em diversos aspectos do que encontramos no Brasil. Tais diferenças que, a princípio, podem parecer meras curiosidades imprimem características importantes ao trabalho desenvolvido na escola. Chartier e Renard (2005) destacam que os alunos trabalham "com" os cadernos e não simplesmente "sobre" esses materiais. Assim, como apontam as autoras, os suportes materiais compõem atitudes e usos, exercem limites, restringem ou ampliam as utilizações possíveis. Suporte e registro não podem, assim, ser compreendidos de maneira independente. Os sentidos atribuídos ao que é registrado são atravessados pelos sentidos atribuídos aos suportes de escrita.

Para começar a abordar as diferenças, vale a pena relatar como foi a minha experiência de adquirir, na França, um caderno para anotar as minhas observações de campo. Após alguns poucos dias em Paris, fui em busca de um caderno em uma pequena papelaria de Malakoff, uma cidadezinha vizinha a Paris onde me alojei. Chegando lá, não vi as costumeiras pilhas de cadernos que ocupam as papelarias brasileiras no início dos anos letivos ${ }^{62}$. A vendedora me atendeu, perguntando o que eu desejava. Disse que queria comprar um caderno. Ela se virou de costas e pegou na estante um pequeno caderno brochura de capa amarela que dispôs sobre o balcão. Perguntei se havia um outro com espiral, e ela, novamente, virou-se de costas e me apresentou outro caderno. Agora com espiral, mas com a mesma capa amarela.

Nesse momento lembrei-me com saudades da diversidade de capas de cadernos brasileiros que, como descreve Mignot (2005), abrangem uma imensa gama de temáticas:

${ }^{62}$ Cheguei à França para a realização da pesquisa em início de outubro de 2005. 0 ano letivo era recém-começado. 
Uma breve visita em qualquer papelaria permite esbarrar em cadernos escolares que estampam capas de cantores, atores, jogadores de futebol, personagens de quadrinhos e jovens pegando onda na prancha de surf, desafiando o mundo sobre patins ou escalando montanhas. (p.175, itálico da autora)

Mobilizada pelas minhas expectativas criadas em solo brasileiro, perguntei à vendedora se havia outros modelos de capas. A vendedora me perguntou qual era a cor que me agradava. Frustrada por ter que decidir sem ter a oportunidade de conhecer os modelos disponíveis, respondi: “azul”. A vendedora fez uma rápida procura em sua sucinta pilha de cadernos e me apresentou um outro, com uma padronagem geométrica bastante simples e semelhante à dos dois primeiros cadernos, porém agora azul. Mais tarde, tive a oportunidade de ir a outras lojas maiores, especializadas em materiais escolares e identifiquei que a diversidade de capas era mínima.

0 fato de os cadernos escolares serem fornecidos gratuitamente a todos os alunos da rede pública certamente diminui consideravelmente o tamanho do mercado consumidor desse material escolar. No Brasil, esse é um mercado que envolve grande volume de recursos financeiros e que usa a tonelada como unidade de medida para avaliar o sucesso de suas vendas (Mignot, 2005). Os estudantes certamente constituem a maioria desses consumidores. Na França, os estudantes não compõem de forma tão maciça esse mercado. Talvez esta seja uma das explicações para que lá os cadernos escolares não sejam mercadorias que mereçam tantos investimentos da indústria papeleira. Em vez de serem objetos de desejo e consumo, os cadernos escolares são padronizados, entregues a todos os alunos independentemente de suas necessidades.

Além de ter de me contentar com a capa que me foi oferecida, tive que me adaptar a uma configuração totalmente inédita das páginas. Quando abri o caderno, percebi que havia uma quantidade imensa de linhas horizontais e verticais. A disposição das linhas parecia-me uma grande confusão, uma poluição visual que atrapalhava consideravelmente $o$ ato de escrever e, sobretudo, tornava a leitura bastante cansativa: 


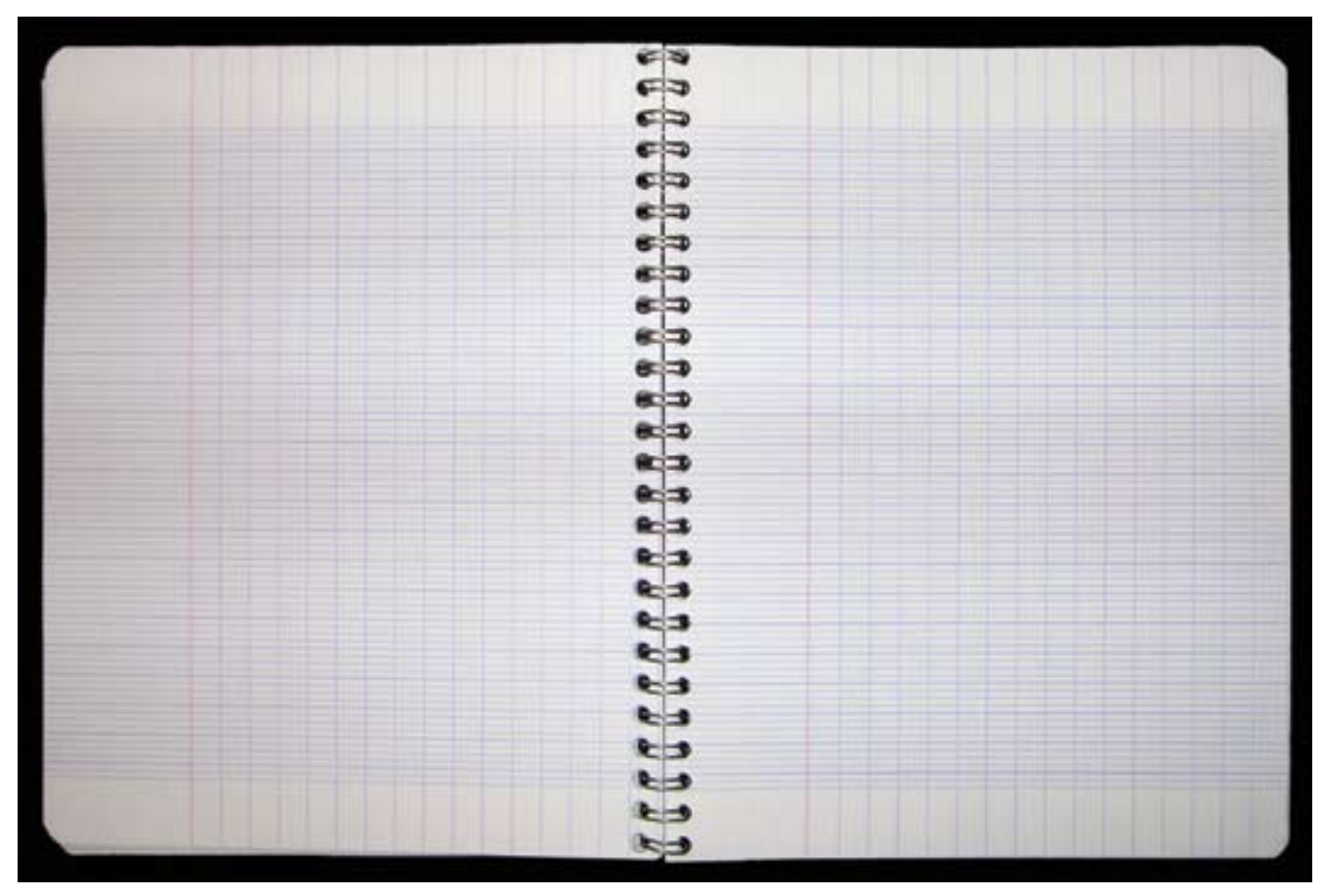

Figura 35. Padrão de linhas de um caderno francês

Esse padrão de linhas, tipicamente francês, foi criado em 1892 por Jean-Alexandre Seyès, um livreiro de Pentoise. Conforme descreve Dancel (2000), tal leiaute foi motivado pela preocupação com a estética da escrita dos estudantes. Numa época em que ter uma letra bonita poderia ser decisivo na conquista de um emprego, o uso de cadernos que tivessem apenas linhas seria insuficiente. Seria necessário "fornecer aos alunos uma forma de traçar as letras corretamente inclinadas e proporcionadas" (Dancel, 2000, p.128, tradução minha). Foi assim que nasceu o padrão até hoje utilizado: "um quadrado de 0,8 cm de lado cortado horizontalmente em 4 espaços de 0,2 cm de altura” (Dancel, 2000, p.128, tradução minha). Chama a atenção a permanência de uma configuração que teve sua pertinência durante muitos anos, mas cujas razões são atualmente anacrônicas.

Antes que o padrão criado para os cadernos por Jean-Alexandre Seyès fosse difundido na França, era comum encontrar cadernos semelhantes aos que atualmente predominam na maior parte do mundo, como mostram as figuras apresentadas por Bukiet e Mérou (2000): 


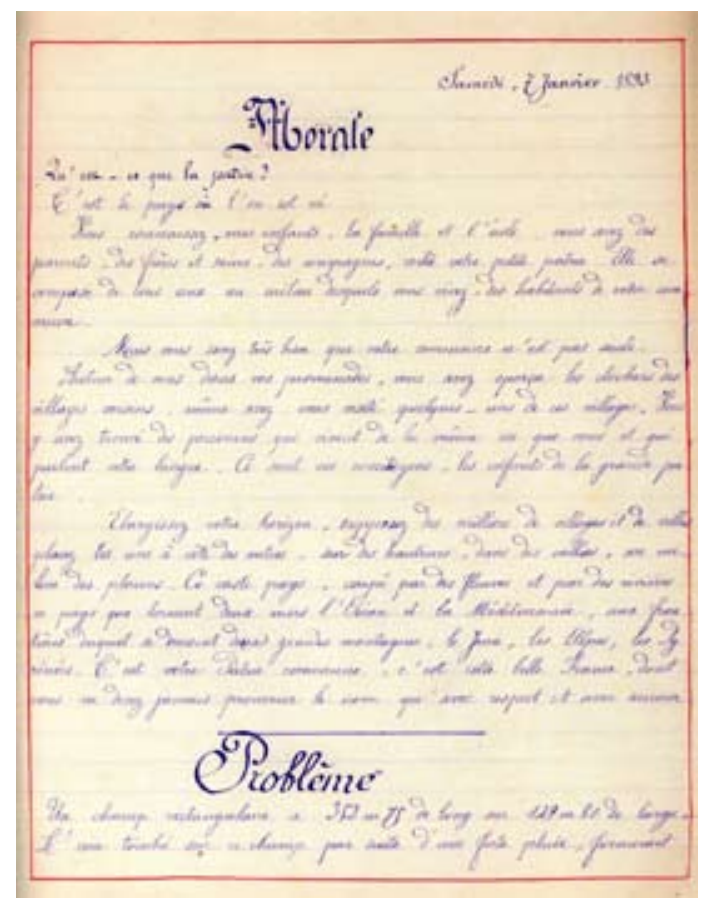

Figura 36. Cópia de Moral realizada no ano de 1893

A figura mostra um traçado das letras bastante elaborado, algo que contrasta com as formas mais simplificadas dos cadernos atuais.

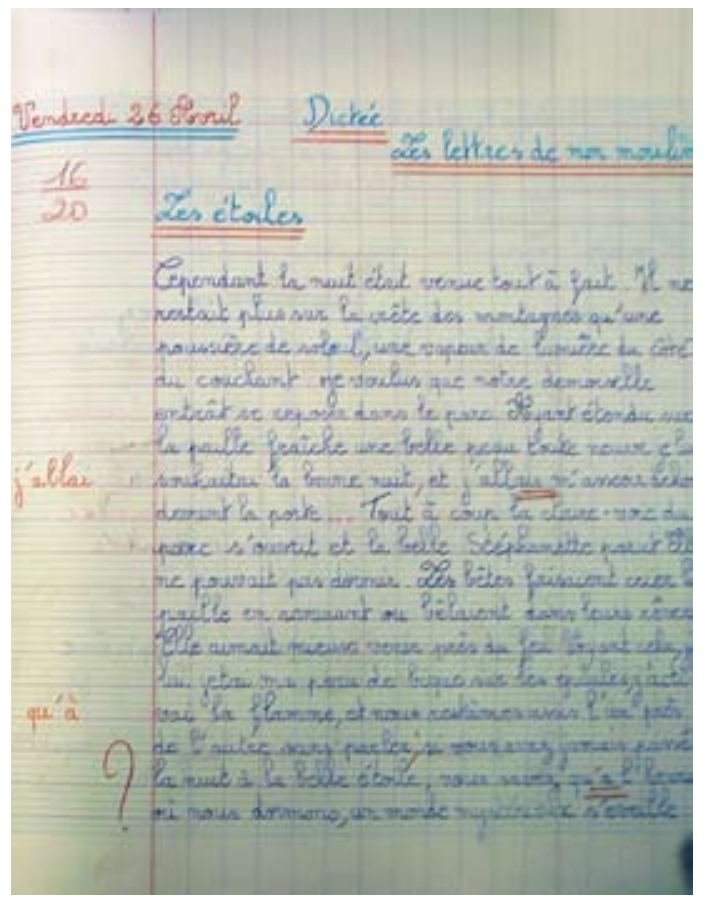

Figura 37. Ditado registrado em 2002 no caderno de aluna de CM2, corrigido pela professora 
Embora atualmente ter uma bonita letra seja menos decisivo no futuro profissional, é possível observar no texto registrado no caderno de uma aluna francesa em 2002 o quanto as linhas continuam guiando o tamanho e o traçado das letras.

Outro aspecto físico importante dos cadernos franceses que vale a pena ressaltar são as margens. Dancel (2000) relata que a linha vermelha que separa a página do caderno em dois espaços - a margem e o resto da folha - é utilizada desde o século XI. A margem destina-se às correções do professor, espaço que somente pode ser utilizado pelos alunos em casos especiais, tais como escrever um título ou responder às correções do professor. A figura acima ilustra o uso francês da margem. A aluna utilizou o espaço apenas para colocar a data, deixando espaço livre para que a professora colocasse a nota e fizesse algumas correções.

No Brasil, a margem não costuma ter uma utilização tão definida. Ainda que, por vezes, ela seja utilizada para as correções, não se caracteriza por ser um espaço de uso exclusivo dos professores. É, até mesmo, muito comum encontrar correções feitas em outros espaços. Em geral, a margem simplesmente delimita o espaço a partir do qual os alunos devem escrever. Possivelmente a subutilização desse espaço esteja relacionada com o fato de as margens no Brasil serem significativamente menores que na França. Encontrei cadernos brasileiros que tinham margens com pouco mais de um centímetro e outros que nem possuíam esse espaço delimitado por uma linha. Os cadernos franceses a que tive acesso, por sua vez, tinham margens de quatro centímetros.

\section{V.4 OS PRIMEIROS APRENDIZADOS SOBRE OS CADERNOS}

No capítulo anterior, relatei aspectos da experiência escolar de alunos de uma primeira série de uma escola pública brasileira. Diante de como eram desenvolvidas as atividades e do não planejamento do ensino do uso dos suportes de escrita, alguns alunos viviam com muitas dificuldades os primeiros aprendizados relativos à escrita e 
ao uso dos cadernos. 0 estudo que realizei em uma sala de aula, sem dúvidas, não tem a potencialidade de expressar o que ocorre de modo geral nas salas de aula brasileiras. Contudo, manifesta algo que é possível e recorrente nas etapas iniciais de ensino.

Se não posso com meu trabalho de pesquisa contemplar a totalidade brasileira, menor ainda é a possibilidade de abranger o que ocorre na França. As 16 observações, realizadas num período de dois meses e meio, apenas me possibilitaram estabelecer um contato inicial e levantar primeiras impressões. Ainda que, de modo algum, haja a intenção de estabelecer verdadeiras comparações entre a educação nos dois países, pretendo, ao apresentar as informações recolhidas nesse contexto distinto do nosso, estabelecer um contraponto. A confrontação com o diferente é tomada, neste trabalho, como algo que abre a possibilidade para questionamentos e reflexões.

Realizei cinco observações em salas de CP, o primeiro ano do Ensino Elementar que recebe alunos de 6 anos. Quatro dessas observações foram realizadas, com freqüência semanal, em uma sala de aula parisiense. Foi uma das salas na qual desenvolvi uma convivência razoavelmente continuada e que me permitiu acompanhar o trabalho de Géraldine, uma professora experiente responsável pela classe.

Quando dei início às observações, as aulas tinham começado havia menos de um mês. Em minha primeira estada na classe, tive a oportunidade de presenciar o procedimento utilizado para que os alunos aprendessem e praticassem o traçado cursivo de letras, sílabas e pequenas palavras da escrita francesa. Os cadernos de todos os alunos tinham sido previamente preparados pela professora, que escreveu da seguinte forma, nas margens das páginas os modelos de letras e sílabas, que deviam ser copiadas pelos alunos ${ }^{63}$ :

\footnotetext{
${ }^{63}$ A figura apresentada refere-se a um caderno utilizado no ano anterior às minhas observações. Quando solicitei à professora alguns cadernos de sua sala para fazer cópias, ela me ofereceu os de alunos que haviam concluído meses atrás o CP. Dessa forma, eu teria mais tempo para providenciar as cópias sem prejudicar o andamento dos trabalhos da sala. Apesar de não se tratar da atividade cuja elaboração acompanhei, a figura apresenta uma estrutura bastante similar.
} 


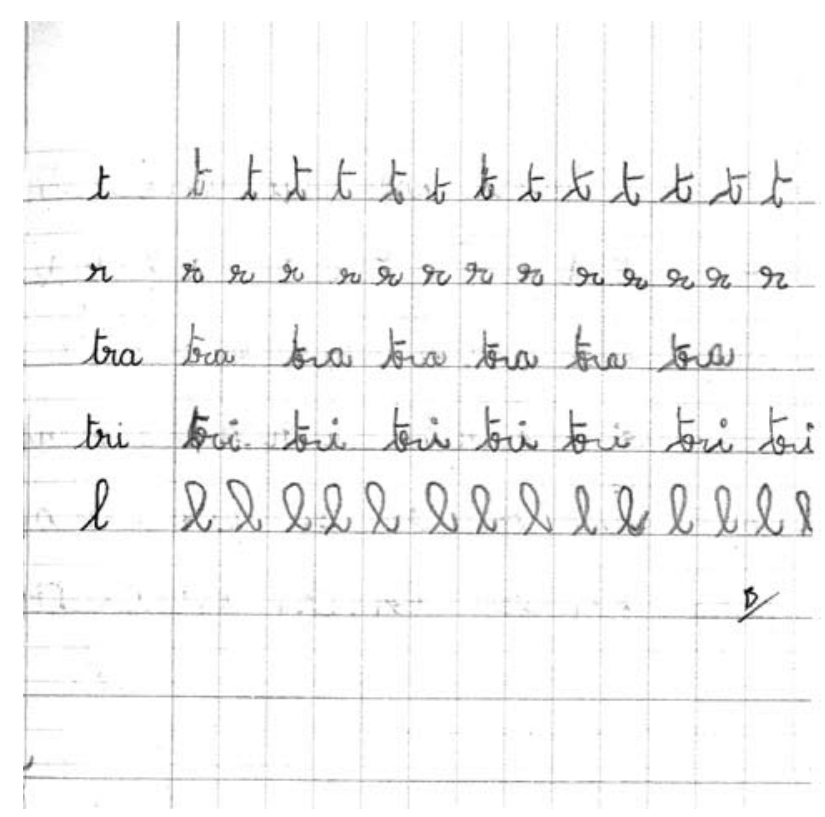

Figura 38. Caderno de Sophie com traçado de letras e sílabas.

Antes que os alunos fizessem a cópia das letras e sílabas, minuciosas instruções foram dadas:

As sílabas-modelo apresentam-se do lado esquerdo da folha dos cadernos. Há algumas linhas entre cada um dos modelos para que os alunos copiem. Os alunos devem escrevê-las algumas vezes (vi repetirem cerca de 6 vezes). Géraldine ensina aos alunos o traçado. Primeiramente faz na lousa, explicando como os alunos devem fazer o "re" em letra cursiva. De costas para a sala, faz o desenho no ar. Os alunos acompanham, repetindo com as mãos erguidas a execução feita pela professora. Enquanto isso, descreve o que faz, de um modo sempre igual, fazendo uma espécie de cantilena que é repetida com o movimento. Os alunos parecem conhecer a cantilena que descreve o traçado das letras e acompanham a professora. Depois de fazer o traçado no ar à frente da sala, vai para o fundo e diz que vai fazer atrás deles para ver como eles fazem.

(RAF 1)

Alguns aspectos me chamaram a atenção. Um deles foi a simplificação do exercício solicitado. Nessa fase de iniciação à escrita cursiva ${ }^{64}$, em que os alunos ainda tinham dificuldades em representar adequadamente cada letra, as atividades restringiam-se ao máximo. Não havia a colocação de cabeçalho ou data. A preparação

\footnotetext{
${ }^{64}$ A iniciação na escrita dá-se com letras de forma na École Maternelle, anterior ao CP.
} 
do exercício feita pela professora, ao mesmo tempo que oferecia aos alunos um modelo, restringia ainda mais o que lhes cabia fazer. A extensão dos conteúdos a ser registrados ia sendo aumentada gradativamente: primeiro apenas letras isoladas, depois sílabas, pequenas palavras, palavras maiores e frases.

Outro aspecto significativo foi o ritual utilizado pela professora para ensinar o modo de traçar cada uma das letras: o movimento corporal de traçar a letra no ar, repetido pela professora e pelos alunos diversas vezes, acompanhado de uma descrição declamada em coro. Por exemplo, ilustra esse ritual o ensino do traçado da letra "u" cursiva:

A professora vai escrevendo na lousa e descrevendo como se faz o u: faço um i e termino, faço outro. Faz para um dos lados da sala, faz para o outro. É interessante este procedimento: quando o professor escreve, cobre com seu corpo, inevitavelmente, a visão para um dos lados da sala. Géraldine faz o traçado duas vezes, mudando de posição e possibilitando que todos os alunos vejam.

(RAF 2)

Ao explicar como deveriam executar o traçado, todas as letras eram associadas a letras que os alunos conheciam:

Explica como devem fazer o traçado da letra u: "u é duas vezes a letra i, mas sem o ponto".

(RAF 2)

Assim, o "t" era um " $\mathrm{i}$ " mais comprido cortado por um traço, o " $m$ " era um " $n$ " e outro "n", e assim por diante. Cada letra com sua cantilena.

Após a explicação, os alunos deviam copiar o modelo em seus cadernos uma série de vezes. Enquanto os alunos faziam a cópia, Géraldine circulava pela sala de aula, conferindo o andamento do trabalho.

Os alunos fazem as letras e Géraldine acompanha. Vai passando pelas carteiras e dizendo "perfeito"; "é uma letra pequena, ela não passa o limite da linha"; "Muito bem"; "Menor, faz nesse espaço aqui"; "Assim está melhor." 
Quando considerava que o traçado estava muito distante do esperado, utilizavase de técnicas, tais como pegar na mão do aluno para conduzir o movimento, ou fazer um novo modelo, desta vez pontilhado, para que o aluno tivesse mais referências para copiar:

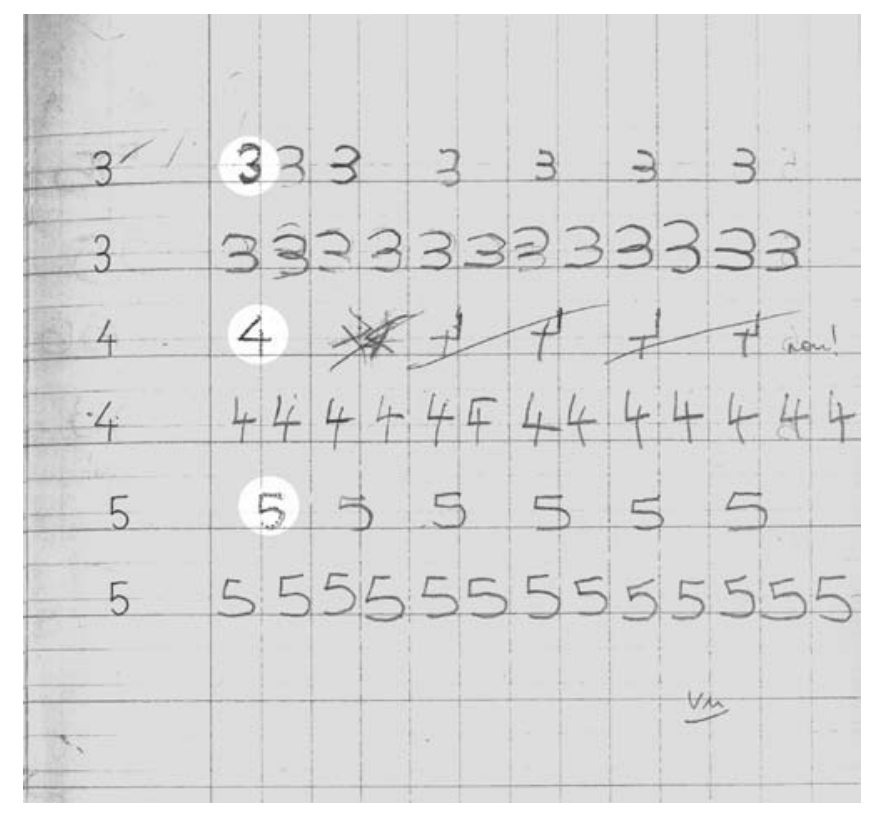

Figura 39. Caderno de Sophie com cópia de números

Todos os procedimentos utilizados para o ensino do traçado das letras acabavam por consistir num modo, bastante gradual e supervisionado pela professora, de iniciar os alunos nas regras básicas de utilização dos cadernos. Saberes tais como o uso de linhas, a seqüência temporal e espacial e os preceitos básicos da escrita compareciam nesses primeiros exercícios solicitados ${ }^{65}$.

\section{V.5 O ACOMPANHAMENTO DOCENTE DOS CADERNOS}

Como ficou evidente na descrição da iniciação dos alunos no uso dos cadernos, as atividades feitas pelos alunos são acompanhadas muito de perto pela

\footnotetext{
${ }^{65}$ Nessa etapa da escolarização, o uso de lápis ainda é permitido. A partir do momento em que os alunos alcançam maior autonomia na escrita, passa a ser permitido escrever apenas a tinta nos cadernos.
} 
professora. Mas não são somente os primeiros passos que contam com um bom acompanhamento docente. Também pude identificar tal proximidade nas salas de séries posteriores que conheci.

Uma característica que me chama a atenção nos cadernos franceses é a recorrente presença de correções, escritos ou assinalamentos feitos pelos professores, freqüentemente, com caneta vermelha. Em cada página preenchida pelos alunos, é possível encontrar traços de verificação docente. As margens, como dito anteriormente, são efetivamente usadas pelos professores para fazer avaliações do trabalho realizado pelos alunos. Nesses espaços, a cada página, é possível encontrar inscrições, tais como, “B”, “AB", “TB”, "Vu”, “à revoir”"66. Também são feitas correções mais diretamente sobre o que foi escrito pelo aluno, como mostra a figura a seguir onde tudo o que está em vermelho (salvo os traços separadores e os sublinhadores) foi feito pela professora:

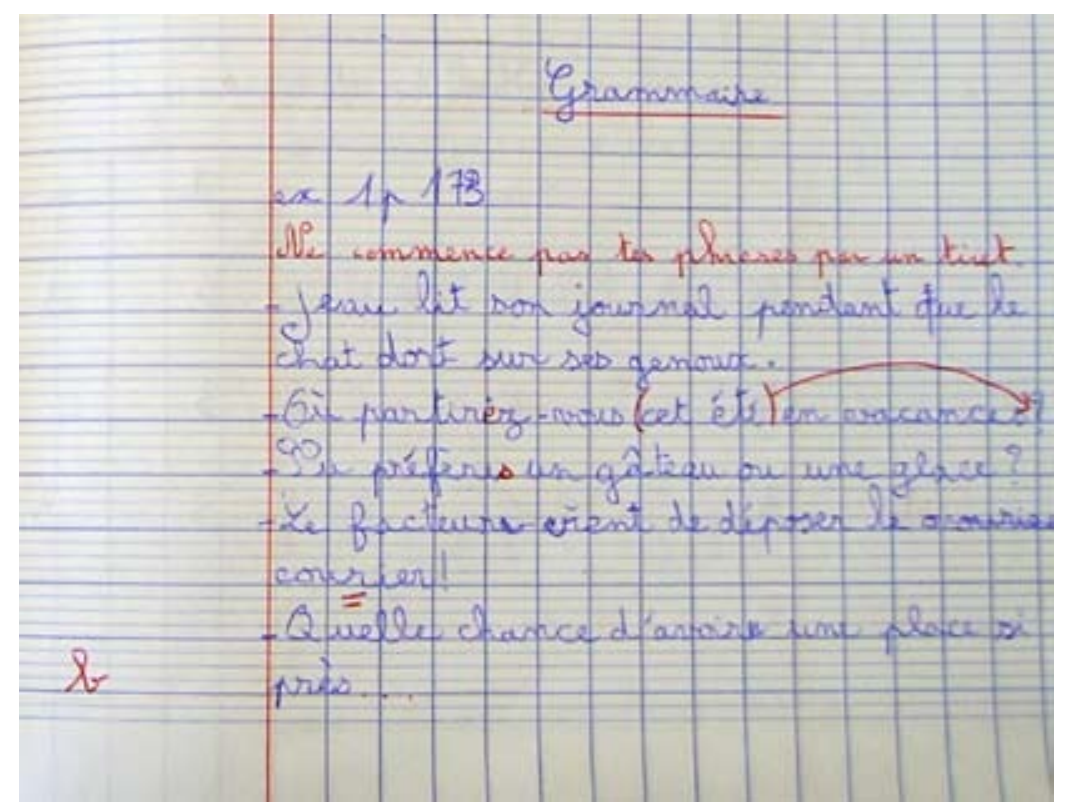

Figura 40. Caderno de Louise, aluna de CM1, com correções da professora ${ }^{67}$

66 “B”, "AB" e "TB" são, respectivamente, abreviações de Bien, Assez Bien e Très Bien, ou seja, Bom, Suficientemente Bom e Muito Bom. "Vu" significa visto e "à revoir" indica que o trabalho deve ser revisto pelo aluno.

${ }^{67}$ Tradução da correção escrita pela professora em vermelho: "Não comece suas frases por um travessão". 
As professoras que acompanhei costumavam formular exercícios personalizados que abordassem os erros mais recorrentes de um determinado aluno. A figura abaixo exemplifica isso:

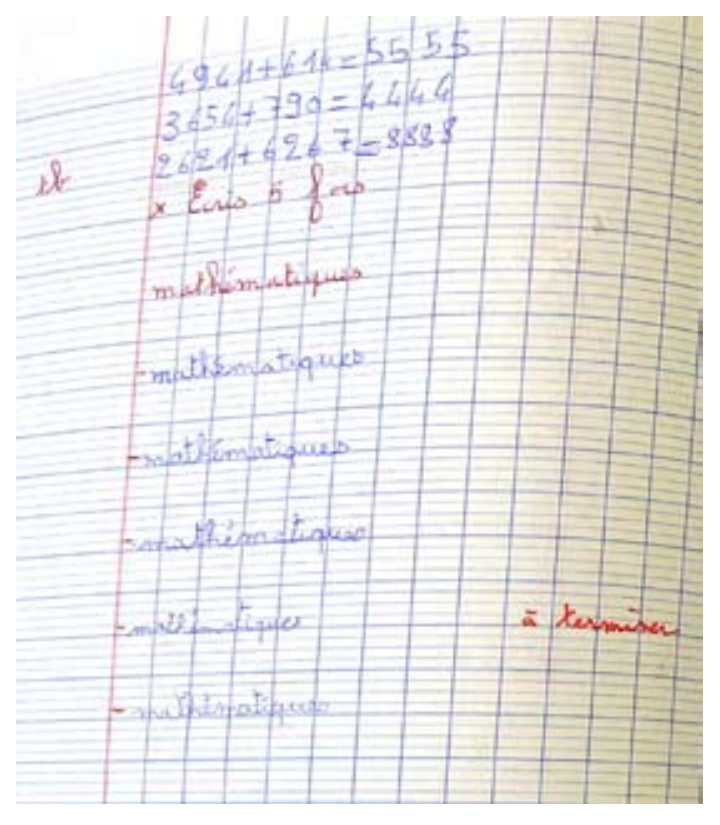

Figura 41. Atividade individualizada solicitada pela professora encontrada no caderno de Lucille

Lucille, aluna de CM1, tinha escrito de modo incorreto em quatro dias consecutivos a palavra "Mathématiques" ${ }^{68}$, que aparecia como título das atividades referentes à disciplina matemática. Ora se esquecia do acento, ora do "s" ao final da palavra; algumas vezes cometia os dois erros. A professora sempre fazia em vermelho as correções, mas os erros persistiam. Diante disso, preparou a atividade acima. Nas atividades subseqüentes desse caderno, a incidência de erros em relação a essa palavra diminuiu.

Outro aspecto significativo são as comunicações escritas que as professoras escreviam para seus alunos. Para exemplificar, destaco comunicações que encontrei nos cadernos de dois alunos de Gisele, uma jovem professora de CM1. Um dos alunos, Hadi, que tinha ascendência árabe, era um dos que mais tinha dificuldades na sala de aula. Segundo a professora, tinha algum nível de deficiência mental e recebia

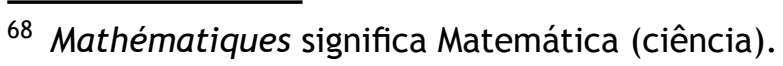


atendimento especializado na própria escola. Havia comunicações de incentivo da professora nas páginas de seus cadernos:

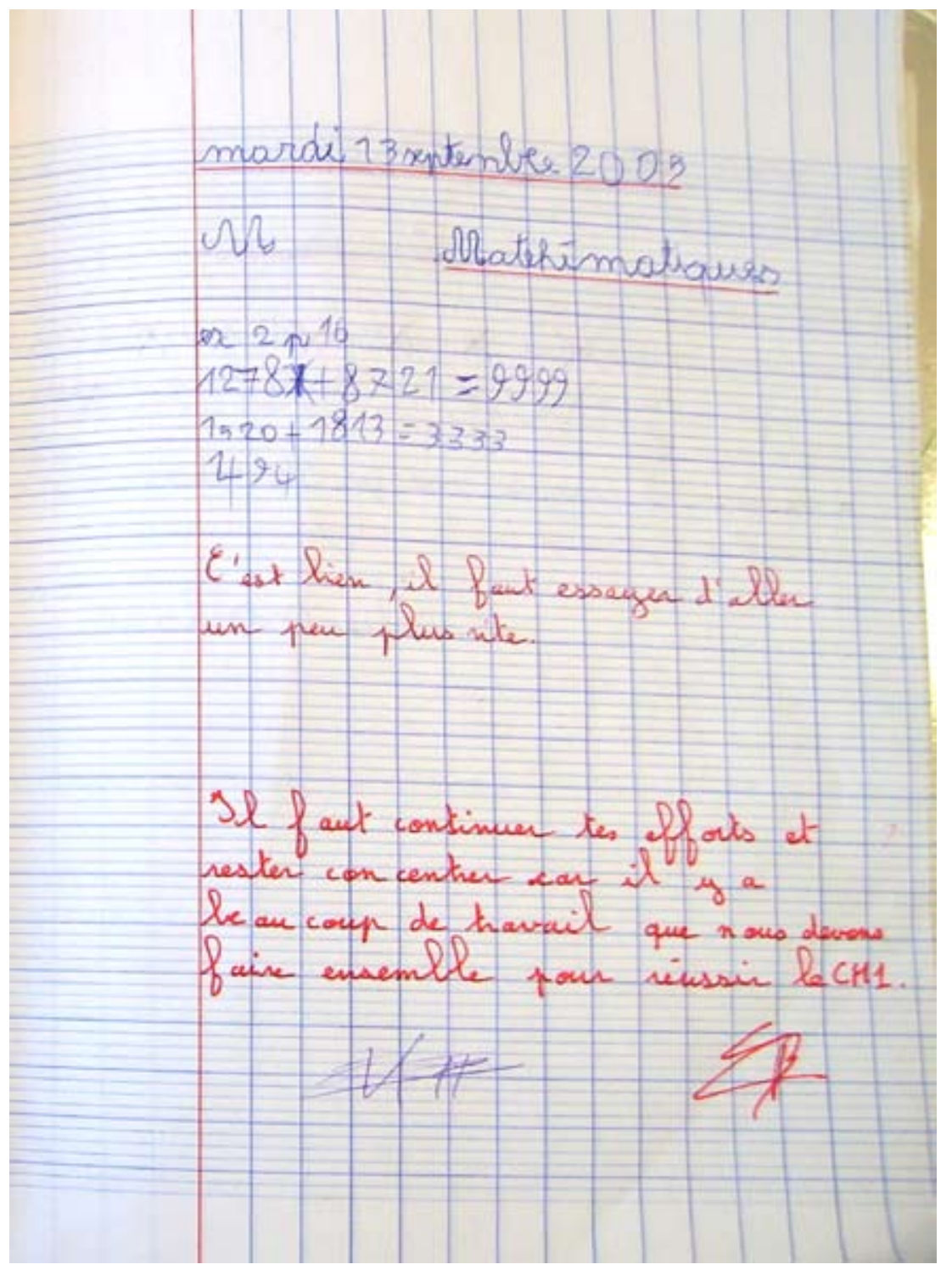

Figura 42. Somas e comunicação docente no caderno de Hadi ${ }^{69}$

Comunicações que faziam repreensões de caráter disciplinar também podiam ser encontradas:

69 Tradução das comunicações escritas pela professora:

“Está bem. É necessário tentar fazer um pouco mais rápido.

Você deve continuar seus esforços e manter-se concentrado, pois há muito trabalho que nós devemos fazer juntos para passar no CM1." 


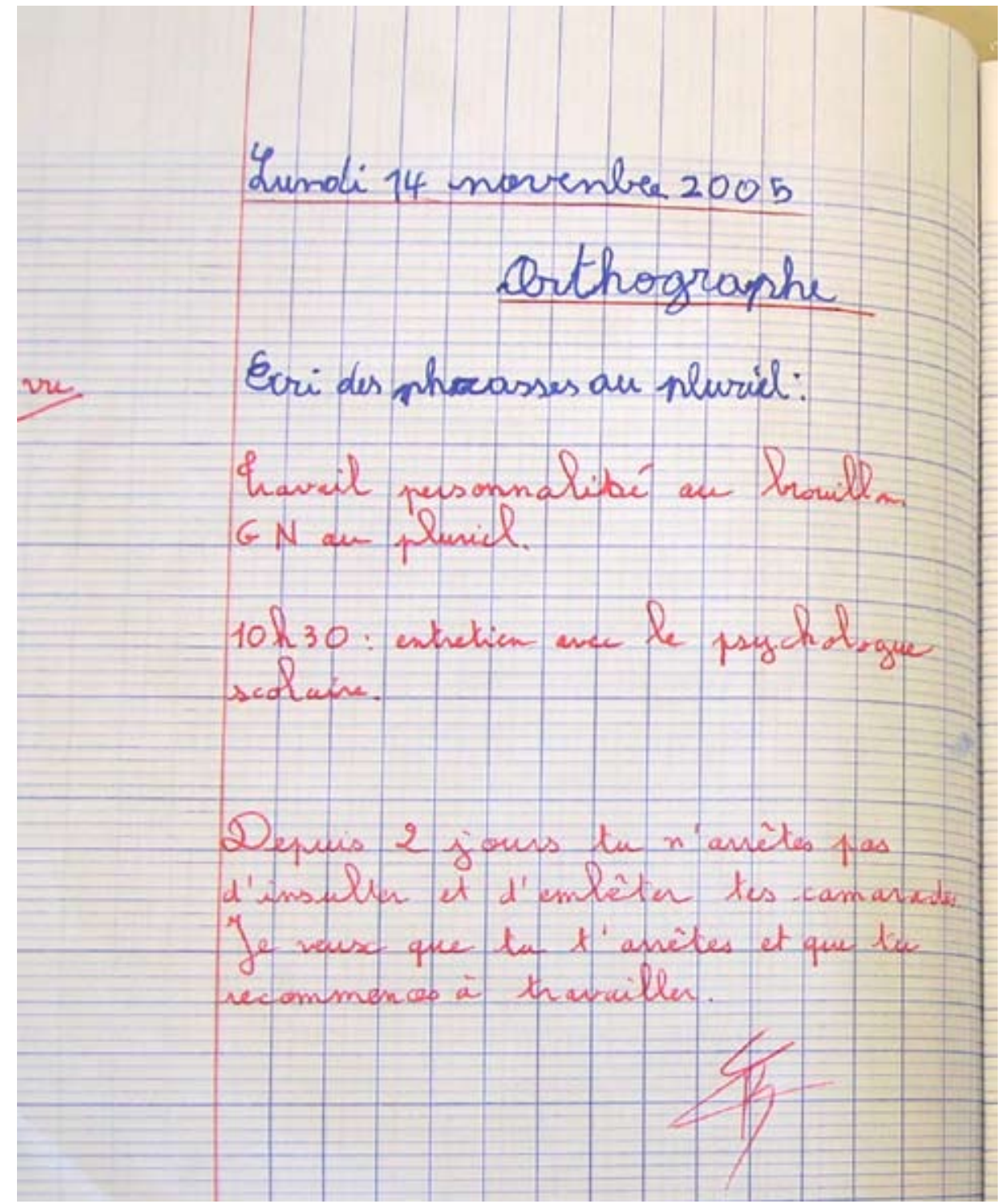

Figura 43. Tarefa não realizada no caderno de Hadi, justificativa da professora e comunicação relativa à disciplina ${ }^{70}$

70 Tradução da página de caderno:

"Segunda, 14 de novembro de 2005

Ortografia

Escreva as frases no plural

Trabalho personalizado no caderno de rascunho (GN?) no plural.

10h30: entrevista com a psicóloga escolar.

Há 2 dias você não pára de xingar e incomodar seus colegas. Eu quero que você pare e recomece a trabalhar". 
Ainda que esse último tipo de comunicação tenha conteúdo bastante próximo do que apresentam os freqüentes bilhetes brasileiros, uma diferença é marcante. Os bilhetes que encontrei aqui se direcionavam invariavelmente aos pais dos alunos, solicitando deles providências em relação a algo que ocorria na escola. No caso das comunicações que apresentei agora, a professora dirige-se ao aluno. Expressa sua opinião a respeito de algo que ocorre, relativo à aprendizagem ou à disciplina, e manifesta a expectativa de modificação. Em geral, a própria professora se implica na resolução da situação apresentada. Na primeira comunicação que apresentei, ela comenta que terão muito trabalho pela frente para que o aluno passe de ano. Em outros momentos, dizia que medida tomaria no caso de um ato indisciplinado persistir (colocar o aluno de castigo no fundo da sala, por exemplo). A maioria das comunicações que vi foram assinadas pelos pais. Ou seja, embora os pais não sejam chamados a resolver as questões, de alguma forma tomam conhecimento e participam do que ocorre na escola.

Esse tipo de comunicação não se restringia aos alunos com maiores dificuldades ou problemas disciplinares, também nos cadernos dos bons alunos era possível encontrar escritos das professoras. Lucille, por exemplo, era uma aluna que se destacava positivamente na sala de aula. Quando pedi à professora para ver os cadernos dos alunos, Gisele separou os cadernos de Lucille e os deixou disponíveis para que eu fizesse cópias. Nesses cadernos, encontrei as seguintes comunicações:

Travail toujours très sérieuse.

Tu as fait des efforts pour prendre la parole plus souvent, c'est très bien il faut continuer.

Bravo pour ton comportement pendant la sortie. ${ }^{71}$

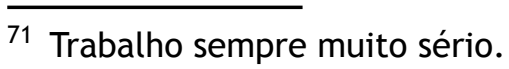

Você tem feito esforços por tomar a palavra mais freqüentemente. Isso é muito bom. Você deve continuar.

Parabéns pelo seu comportamento na saída.
} 


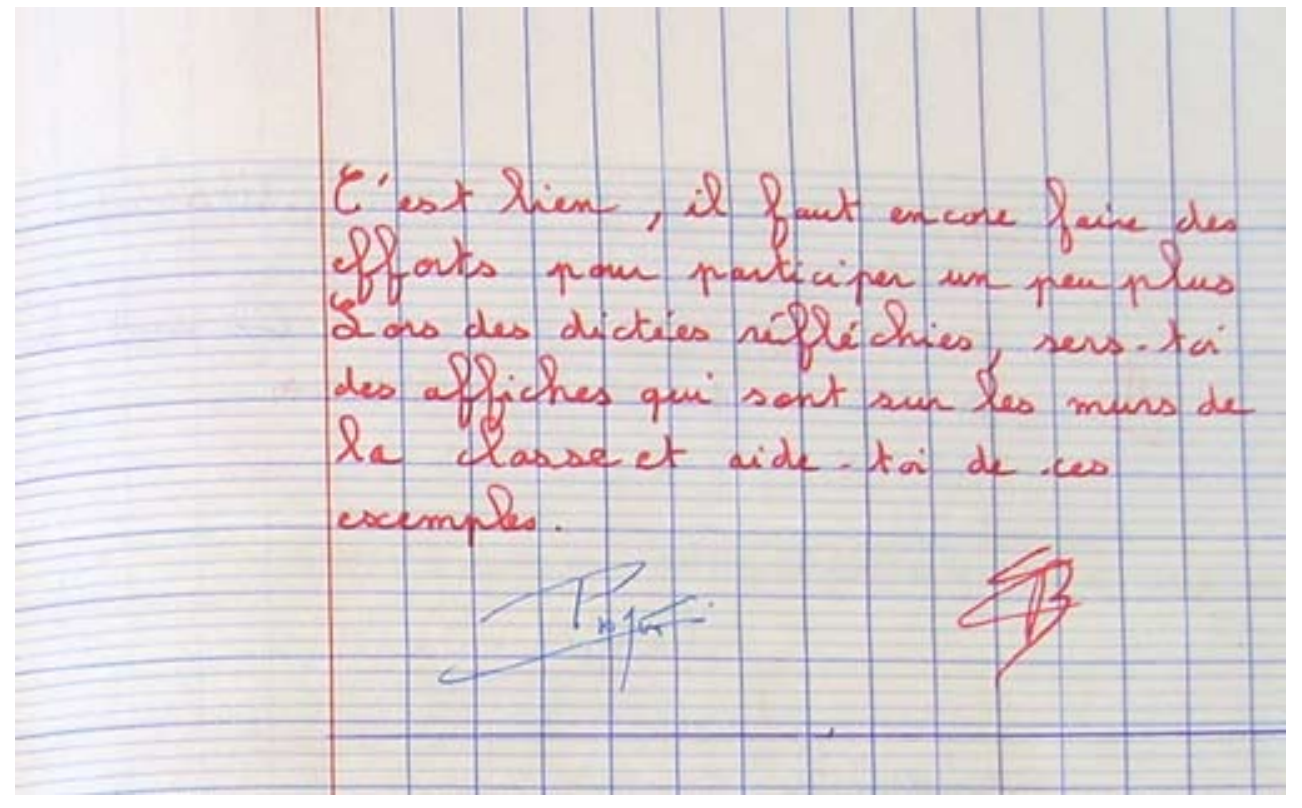

Figura 44. Comunicação feita pela professora no caderno de Lucille $^{72}$

Além dos elogios, apareciam nessas comunicações incentivos, para que a aluna pudesse superar a timidez, e sugestões para melhorar ainda mais o seu desempenho acadêmico.

A fim de que as professoras pudessem realizar esse acompanhamento tão próximo dos cadernos de seus alunos, algumas rotinas eram estabelecidas nas salas de aula. Um procedimento usual era que, ao final de cada aula, os alunos entregassem seus cadernos para que fossem corrigidos. Pude acompanhar salas em que os alunos, antes de saírem no final do período, deixavam seus cadernos abertos na página correspondente aos trabalhos do dia, formando uma pilha em cima da mesa do professor.

É importante ressaltar que a verificação detalhada e sistemática das produções discentes é algo que requer condições de trabalho. 0 modo pelo qual os professores franceses acompanhavam os cadernos de seus alunos indica que tais procedimentos faziam parte de suas atribuições, constituindo uma parcela importante de seu

\footnotetext{
72 "Está bom. Você ainda deve fazer esforços para participar um pouco mais. Durante os ditados refletidos, use os cartazes que estão nas paredes da classe e utilize os exemplos." (Os ditados refletidos são de uma modalidade especial de ditado. Primeiramente, frases eram ditadas e os alunos as escreviam. Depois, era feita uma reflexão, baseada em aspectos gramaticais, a respeito de como cada uma das palavras devia ser escrita).
} 
trabalho. Nas escolas que conheci na França, os professores cumpriam essa tarefa na própria escola, durante seu período de trabalho. Nas escolas públicas brasileiras, usualmente, os horários de trabalho pedagógico fora de sala de aula são bastante restritos, e, em geral, professores verificam os cadernos enquanto os alunos realizam as atividades, ou utilizam seus momentos de descanso para fazer as correções.

\section{V.6 AS REGRAS DE UTILIZAÇÃO DOS CADERNOS}

Os cadernos de alunos franceses a que tive acesso pareciam-se muito mais entre si do que os cadernos de alunos brasileiros. No Brasil, como foi descrito nos capítulos anteriores, é comum que os alunos façam diversas escolhas a respeito do modo pelo qual vão dispor as informações em seus cadernos. Deixar linhas em branco, mudar de página ou continuar na mesma página, utilizar lápis ou caneta, registrar de modo colorido ou monocromático e fazer desenhos são algumas das opções que, freqüentemente, podem fazer. Diferentemente, nas salas de aula francesas que pude conhecer, todos esses procedimentos são determinados pela professora e seguem um padrão que deve ser adotado por todos os alunos da classe.

Embora entre os diferentes cadernos de alunos franceses haja mais semelhanças do que entre os de brasileiros, certamente não existem regras únicas em todas as salas de aula francesas. Para organizar as páginas dos cadernos, os alunos seguiam alguns preceitos, que variavam de sala de aula para sala de aula, mas sempre presentes e exigidos pelas professoras. A fim de exemplificar os tipos de normas existentes, descreverei as regras que pude observar nas salas de aula das professoras Claire e Gisele de CM1. Elas trabalhavam na mesma escola, em salas de aula vizinhas. Organizavam-se de modo que ambas trabalhavam com os alunos das duas salas, cada uma era responsável por um conjunto de disciplinas. Gisele era uma professora jovem, bastante rígida e severa. Claire, também jovem, parecia mais tolerante. Do conjunto de educadores cujo trabalho pude conhecer, Claire seria uma das professoras menos rígidas em relação às regras de utilização dos cadernos. Foi nas salas de aula dessas 
professoras que pude acompanhar situações que, mais explicitamente, ilustram o modo pelo qual as regras de uso dos cadernos compõem a rotina de uma classe francesa. Além disso, foram professoras com as quais tive a possibilidade de conduzir um estudo mais prolongado, que consistiu num conjunto de cinco observações. Outro aspecto que contribuiu para a escolha da descrição das regras dessas salas de aula foi o fato de o CM1 corresponder ao quarto ano do Ensino Elementar, assim como a quarta série brasileira.

Foi Gisele quem me disponibilizou cadernos de alunos para que eu pudesse fazer fotos. A cada dia, o registro nos cadernos era iniciado pela escrita da data no seguinte formato:

Lundi 14 novembre $2005^{73}$

A data deveria ser escrita com caneta azul e sublinhada com caneta vermelha. Caso houvesse anteriormente algum outro registro nessa página, um traço horizontal azul, começando na margem e indo até o fim da linha, devia ser feito para separar um dia do outro. A seguir, deixando uma linha em branco, vinha o título da atividade. O título devia ser escrito com caneta azul e sublinhado com a caneta vermelha. Era recomendado que fosse posicionado com um recuo em relação à margem, e assim devia ser escrito a partir do quinto quadrado. Referiase ao tipo de conhecimento abordado, por exemplo: “Mathématiques", "Lecture”, "Sciences" ou "Conjugaison"74.

No caso de mais de um tipo de conhecimento ser abordado em um mesmo dia, um traço horizontal deveria separar as atividades. Nesse caso, era feito um traço, mais curto que o utilizado para separar um dia do outro, que ocupava apenas cinco quadrados.

\footnotetext{
73 Em português: Segunda-feira, 14 de novembro de 2005.

74 Em português, respectivamente: Matemática, Leitura, Ciências ou Conjugação.
} 
Os desenhos somente compareciam nos cadernos quando relacionados com o tema abordado e devidamente solicitados pela professora. Os enfeites eram padronizados e estabelecidos.

No geral, nas salas de aula que conheci, o uso do lápis era raro, permitido somente nos cadernos de rascunho. Nas aulas de Claire, essa regra era relativamente mais flexível e, assim, era possível encontrar algumas atividades feitas a lápis nos cadernos de seus alunos.

Escrever a caneta era a regra, nessa etapa da escolarização. Até mesmo os cálculos eram realizados a tinta. A caneta vermelha era preferencialmente utilizada pelas professoras para fazerem as correções e as demais comunicações. Também podia ser utilizada pelos alunos para sublinhar palavras ou fazer os traços separadores, mas não era usual que utilizassem essa cor para escrever. A caneta verde também era bastante utilizada pelos alunos, sobretudo nos momentos em que faziam autocorreções. 0 código de cores adotado possibilita, por exemplo, que alguém que verifique o caderno reconheça e diferencie atividades corrigidas pela professora e correções efetuadas pelo próprio aluno.

Chartier (2001) aponta que a realização dos trabalhos escolares em conformidade com os padrões dá aos professores indícios importantes de que os alunos interiorizaram as normas escolares, e, assim, garantir que seguissem as regras era objeto de preocupação da professora. Com freqüência, eram dadas indicações verbais e/ou escritas buscando garantir que os alunos mantivessem o modo de apresentar as informações nos cadernos. Na imagem a seguir, por exemplo, a professora escreveu uma recomendação, indicando que a aluna sublinhasse o título: 


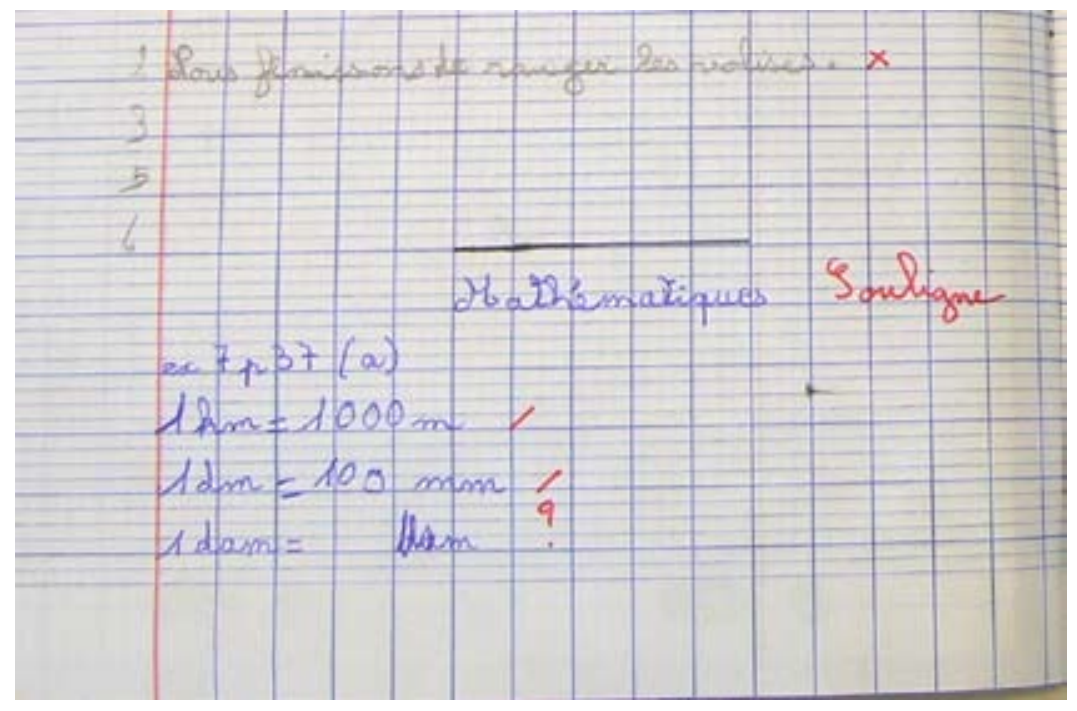

Figura 45. Recomendação para que a aluna sublinhe o título, escrita pela professora no caderno de Lucille

No mesmo caderno, a professora adverte a aluna por ter escrito o título na margem do caderno e recomenda que ela "escreva o título a partir do quinto quadrado":

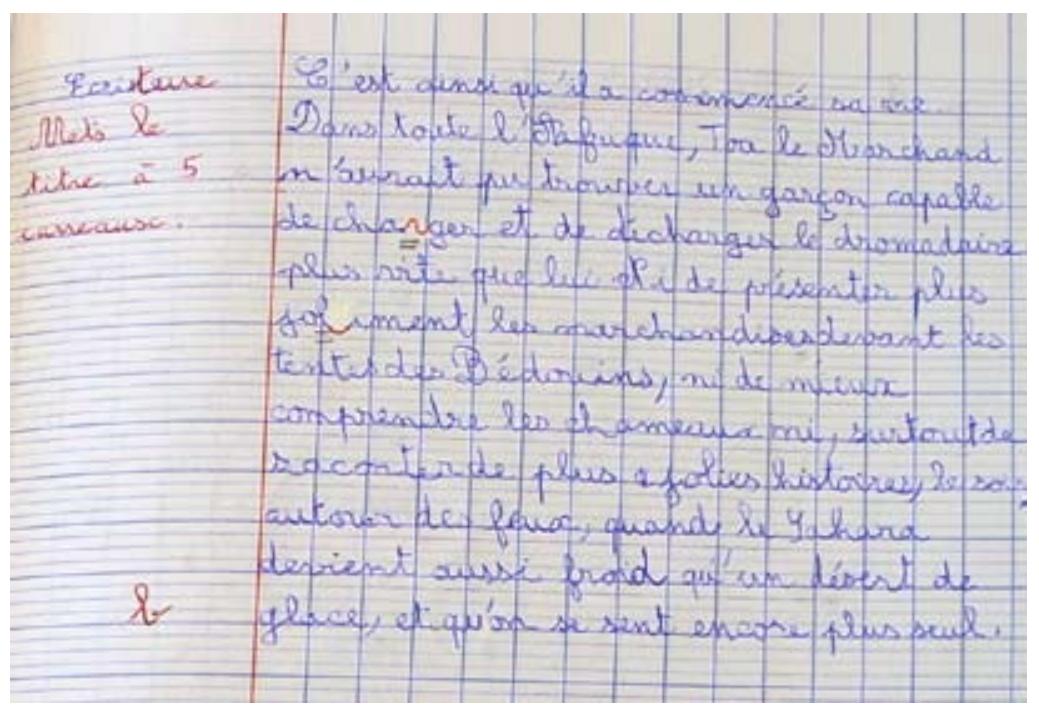

Figura 46. Advertência relativa ao local onde deve ser escrito o título, encontrada no caderno de Lucille

Mesmo alunos como Hadi, que tinham dificuldades para cumprir as atividades propostas e apresentavam cadernos mais desorganizados, seguiam os preceitos de preenchimento dos cadernos. 
Tive acesso a cadernos de outras escolas e foi possível identificar que os padrões de organização dos cadernos tinham diferenças quanto aos espaços onde as informações deveriam ser dispostas e às cores utilizadas. Nos cadernos de CM2 de uma escola rural, por exemplo, a data deveria ser escrita em vermelho e duplamente grifada em azul. Os títulos deveriam ser escritos em azul e duplamente grifados em vermelho. Apesar das diferenças, algo se mantém: a padronização das normas utilizadas para dispor as informações.

Acompanhar a rotina da sala de aula de Claire pode ilustrar a maneira pela qual tais normas compareciam no desenvolvimento das atividades. Apresentarei um trecho de uma das observações realizadas que consistiu numa aula sobre os estados físicos da água e teve como atividade inicial a cópia do seguinte texto:

$. \quad . \quad$. Leçon : L'eau ${ }^{75}$
L'eau se transforme en eau
solide (glace) à $0^{\circ}$. Cette transforma-
tion s'appelle : la solidification.
La glace se transforme en eau
liquide à $0^{\circ}$. Cette transformation
s'appelle : la fusion.
L'eau liquide peut se transformer
en vapeaur d'eau (gaz). Cette
transformation s'appelle l'evaporation
On remarqué que l'evaporation est
plus rapide quand la temperature
est élevée et quand la surface
entre l'eau et l'air est grand
On remarqué que l'eau
en se solidifiant augmente
de volume (prend plus
de espace)

75 “Lição: A água. A água se transforma em água sólida (gelo) a $0^{\circ}$. Essa transformação se chama: solidificação. $O$ gelo se transforma em água líquida a $0^{\circ}$. Essa transformação se chama: fusão. $A$ água líquida pode se transformar em vapor d'água (gás). Esta transformação se chama evaporação. Nós observamos que a evaporação é mais rápida quando a temperatura e quando a área de contato entre a água e o ar é grande. Nós observamos que a água, ao se solidificar, aumenta de volume (ocupa mais espaço)". 
A professora começa a passar na lousa um texto. Ela escreve lentamente, dizendo em voz alta o que escreve e convidando os alunos a participar. Faz perguntas sobre o conteúdo. Em geral, antecipa em suas perguntas o que vai escrever na lousa momentos depois. Ou seja, a escrita do texto na lousa se dá de modo bastante interativo com os alunos.

Começa dizendo: "pulem 4 quadrados e escrevam...". Assim, após os quatro quadrados, indicados na lousa por pontinhos, os alunos devem escrever o título: "Leçon : L'eau"

Ela faz na lousa a margem dos cadernos e os quatro pontinhos (indicando o número de quadradinhos a ser pulados).

Após escrever o título na lousa, a professora recomenda: "sublinhem em vermelho". [...]

Ela ia avisando, no começo de todos os parágrafos, a necessidade de pular uma linha: "então, vocês vão pular uma linha e na próxima linha vocês vão escrever a partir da margem".

Especialmente no começo da atividade, é surpreendente a quantidade de indicações que a professora dá a respeito de como devem ser copiadas as informações. Quando ela acaba de escrever a primeira linha, diz: "eu mudo de linha, mas vocês continuam porque pra vocês haverá espaço". [...]

A professora chega, novamente, ao fim da linha. Desta vez tem que dividir a palavra "transformation" com um hífen, pois não há espaço na lousa. Avisa: "eu vou cortar a palavra, mas vocês terão espaço".

Fala a palavra "solidification", sílaba a sílaba, algumas vezes. Diz que é importante que os alunos conheçam essa palavra.

Vejo que os alunos copiam.

Quando acaba o parágrafo, Claire diz: “em seguida, vocês pulem uma linha". Ela vai escrevendo na lousa e perguntando aos alunos: "qual é a temperatura em que a água se transforma em gelo?" [...]

Um dos alunos estranha a separação da palavra "transformation" na lousa. Pergunta por que a professora não continuou na parte branca da lousa (há duas lousas, lado a lado, uma verde e uma branca). A professora explica que o giz não funcionaria na outra lousa, pois ela é branca. Acrescenta que é a mesma coisa que acontece com eles: quando acaba a página do caderno, eles não escrevem na mesa.

Os alunos copiam.

Professora diz: "Em seguida, pulem uma linha". Explica que vai mudar de lousa, mas que eles podem continuar embaixo.

Um aluno pergunta: "nós continuamos?", e a professora repete: "pule uma linha".

Escreve a primeira condição para que a evaporação aumente e pergunta aos alunos se eles sabem qual é a outra. Um aluno fala de aumentar a superfície. Ela concorda e diz que é exatamente isso.

Aluno reclama que está muito pequena a letra da professora na lousa. E ela concorda e logo providencia uma cadeira para que ele se sente à frente.

Professora pára um pouco, vai observando o andamento do trabalho dos alunos. Parece esperar por eles. Depois de um tempo, pergunta: "Posso apagar este lado?" (um dos lados da lousa). Os alunos não apresentam oposição. [...]

No texto escrito na lousa, ela utiliza a palavra "aumenta". Pergunta aos alunos o que a palavra quer dizer. Uma aluna diz "subir", 
a professora não concorda. Outros alunos dão sugestões e, por fim, ela escreve na lousa "tomar mais espaço".

Um aluno pergunta: "é aqui que nós terminamos?". Ela concorda.

Por fim, escreve na lousa quais são as palavras que eles devem sublinhar em vermelho: "solidification, fusion, evaporation".

Ao acompanharmos as atividades da sala de Claire, é possível identificar que, durante toda a realização da cópia, houve recomendações relativas a como deveria ser a apresentação do texto copiado. A cor de cada uma das partes do texto, a distância a ser adotada entre a margem e o título, as linhas a ser puladas, tudo isso foi estabelecido pela professora. 0 fato de Claire ser uma professora relativamente tolerante quanto à apresentação dos cadernos nos ajuda a compreender o quanto o seguimento de alguns preceitos básicos foi essencial no modo de organização das salas de aula que acompanhei. Essa maneira de configurar os cadernos comparecia nos cadernos da sala de aula.

Ainda que as regras fossem variáveis de sala de aula para sala de aula, a presença de preceitos bastante definidos para o registro das informações nos cadernos era uma constante.

Todo esse conjunto de regras que regem o preenchimento dos cadernos pode auxiliar a compreender algumas características que diferenciam cadernos brasileiros e franceses. As regras vigentes em cada um dos países, arraigadas na cultura escolar local, compõem fortemente o modo pelo qual se conforma a apresentação desses registros.

\section{V.7 A DIVISÃO DE CADERNOS}

Chartier e Renard (2000) conduziram uma pesquisa com professores franceses a respeito dos suportes de escrita que utilizavam com seus alunos. Considerando os professores que atuavam nos níveis de ensino equivalentes ao primeiro ciclo do ensino fundamental brasileiro, as autoras encontraram educadores que utilizavam entre seis e 16 diferentes suportes de escrita. Os professores relatavam usar diversos tipos de cadernos, ardoises, fichários e livros de atividades. 
Outra pesquisa sobre o mesmo tema foi realizada por Giguere e Reuter (2003), em salas de Cours Élémentaire 2 (CE2) e CM1, em duas escolas, sendo uma escola tradicional e uma escola que utiliza a pedagogia Freinet $^{76}$. Os pesquisadores fizeram, primeiramente, um levantamento entre os professores a respeito dos suportes de escrita utilizados, obtendo números que variavam entre 12 e $14^{77}$.

Essa diversidade de suportes de escrita foi algo que me chamou a atenção nas salas de aula cujo trabalho acompanhei. Os cadernos utilizados pelos alunos não seguiam uma divisão padrão nas escolas visitadas. No entanto, em qualquer dos estabelecimentos de ensino, a quantidade de cadernos utilizada sempre foi grande. A lista de cadernos utilizados em uma das salas de aula de CM1 acompanhada pode ilustrar como essa organização se dava:

Tabela 3. Lista de cadernos de uma sala de aula francesa

Nome do Caderno $\quad$ Forma de Utilização

Utilizado para as atividades realizadas em sala de aula.

Cahier de Classe É o mais utilizado. Permanece na escola. Todos os dias é corrigido e a cada 15 dias é enviado aos pais com comentários da professora. Os pais devem assinar.

Cahier de Devoir
Onde são realizadas as tarefas para casa. Utilizado e levado para casa diariamente.

\footnotetext{
${ }^{76}$ Célestin Freinet, educador francês crítico da escola tradicional e da Escola Nova, desenvolveu um movimento pedagógico centrado na criança e baseado em princípios tais como: senso de responsabilidade e cooperação, sociabilidade, julgamento pessoal, autonomia, expressão, criatividade, comunicação, reflexão individual e coletiva e afetividade. Algumas técnicas, tais como a aula passeio, a imprensa escolar, o livro da vida, a correspondência interescolar e a auto-avaliação são características da pedagogia Freinet.

77 A segunda etapa da pesquisa consistiu na realização de entrevistas com alunos das salas de aula para identificar se eles eram capazes de nomear e descrever todos os cadernos e fichários utilizados, bem como para verificar se conseguiam associar as disciplinas escolares aos cadernos e fichários correspondentes. Ainda nesta seção, serão abordados os resultados dessa etapa da pesquisa.
} 
Nome do Caderno

Cahier de Recherche

Cahier de Travail Autonome

Cahier de Histoire e Géographie

Cahier de Science

Cahier de Éducation Civique

Cahier de Poésie

Cahier de Textes
Forma de Utilização

Caderno destinado a rascunhos; sua utilização fica a critério do aluno. Não são feitas correções pela professora, exceto quando utilizado para rascunho de textos que serão passados a limpo.

Utilizado quando os alunos acabam de fazer as tarefas solicitadas em classe. Os alunos podem solicitar à professora que thes passe uma lição extra segundo suas preferências ou a professora determina de acordo com as dificuldades identificadas no aluno. Permanece na escola.

Utilizado para os textos de história e geografia (Os exercícios são feitos no cahier de classe). Há a pretensão de torná-lo um caderno de referência, utilizado por três anos letivos, do CE 2 ao CM 2. Permanece na escola.

Utilizado para copiar os textos de ciências. Diferenciase por ter folhas em branco para fazer esquemas. Permanece na escola.

Caderno destinado ao conhecimento das instâncias de decisão do país.

Utilizado para a cópia de poemas, em geral de autores reconhecidos, para que os alunos os conheçam, guardem e decorem. Caderno de referência. Permanece na escola.

Utilizado como agenda, é o lugar para que os alunos anotem aquilo que devem fazer. Destaca-se que este é o único caderno comprado pela família do aluno, os demais cadernos são dados pela Mairie. Levado diariamente para casa. 
Nome do Caderno

Cahier de Anglais

Cahier de Liaision

Cahier de Contrôle
Forma de Utilização

Reúne todas as atividades de língua inglesa, disciplina ministrada por uma professora especializada.

Permanece na escola.

Destinado às comunicações com a família. Levado diariamente para casa.

Onde são coladas todas as avaliações feitas pelo aluno. Há um sistema de quadradinhos pintados para indicar como o aluno está em cada modalidade avaliada. Os resultados dessas avaliações são enviados aos pais numa ficha que deve ser assinada.

Além desses 12 cadernos, a professora Gisele relatou pretender fazer mais um com seus alunos: o Cahier de Mots. Seria um caderno de referência utilizado para que os alunos decorassem a grafia correta das palavras. A professora hesitava em levar adiante sua intenção, pois havia um dilema para o qual ainda não tinha encontrado solução: ou passava as palavras na lousa e corria o risco de que os alunos as copiassem de modo incorreto, ou teria que corrigir, um a um, os cadernos. Além dos cadernos, pude acompanhar o uso freqüente das ardoises.

Uma professora da mesma escola, Lina, sabendo do meu interesse em pesquisar o uso dos cadernos na França, gentilmente preparou uma descrição da divisão adotada em sua sala de CP. Vale a pena mostrá-la para que fiquem exemplificados os tipos de suportes de escrita utilizados nos diferentes níveis de ensino: 

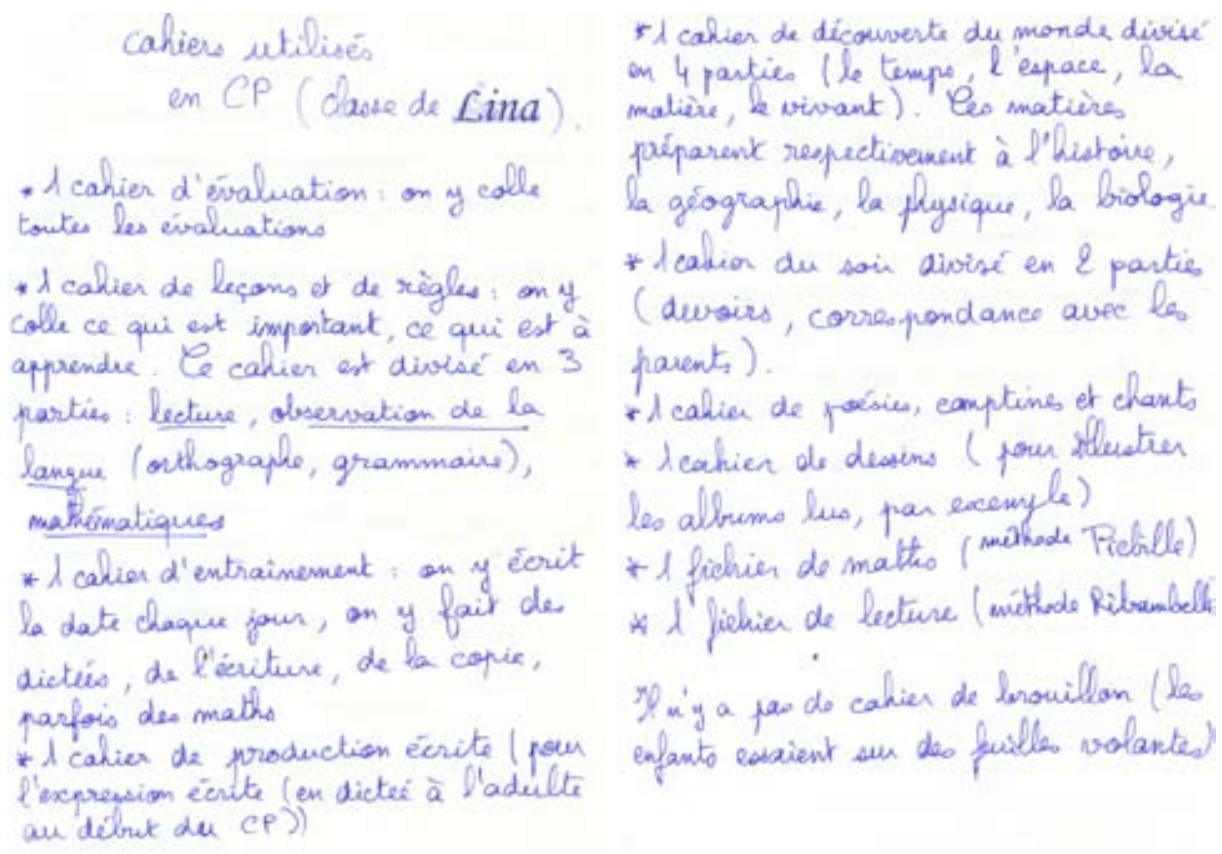

Figura 47. Lista de cadernos utilizados em sala de $\mathrm{CP}^{78}$

Confesso que as listagens e descrições relativas aos vários suportes de escrita me deixaram bastante confusa. Apesar do empenho e da disponibilidade das professoras para esclarecer minhas dúvidas, em nenhum momento cheguei a ter clareza de qual atividade deveria ser feita em qual caderno, dado que tanto havia cadernos que reuniam diversas áreas de conhecimento, quanto disciplinas que estavam presentes em mais de

78 Tradução da listagem preparada pela professora:

Cadernos utilizados no CP (classe de Lina)

- 1 caderno de avaliação: onde colamos todas as avaliações

- 1 caderno de lições e de regras: onde colamos o que é importante e que deve ser aprendido. Este caderno é dividido em 3 partes: leitura, observação da língua (ortografia e gramática), matemática - 1 caderno de exercícios: onde escrevemos a data, exercícios de escrita, cópia e, às vezes, matemática.

- 1 caderno de produção escrita (feita por meio de ditado ao adulto, no começo do CP)

- 1 caderno de descoberta do mundo dividido em 4 partes (o tempo, o espaço, a matéria, os seres vivos). Essas matérias preparam, respectivamente, para história, geografia, física e biologia.

- 1 caderno de fim de tarde dividido em 2 partes (deveres e correspondência com os pais)

- 1 caderno de poesias, canções infantis e músicas.

- 1 caderno de desenhos (para ilustrar os livrinhos lidos, por exemplo)

- 1 livro de exercícios de Matemática (método Picbille)

- 1 livro de exercícios de leitura (método Ribambelle)

Não há caderno de rascunho (as crianças fazem rascunhos em folhas soltas) 
um caderno. Surpreendia-me que crianças de 6 anos, como as de CP, tivessem que se organizar para utilizar corretamente tantos cadernos diferentes e subdivididos.

Para os alunos, obedecer tal divisão não era uma tarefa simples. As professoras relatavam a constante vigilância necessária para que os alunos pegassem os cadernos corretos, os freqüentes enganos e a insuficiência de nomear a disciplina a que se referia cada atividade, o que implicava na necessidade de recorrer à cor ou ao tamanho do caderno para indicar aos alunos onde deveriam trabalhar. Era recorrente que alunos e professoras reconhecessem os cadernos pelas cores:

Gisele indica qual é o caderno que os alunos devem utilizar: “É o caderno rosa pequeno".

Claire pede aos alunos que peguem os cahiers de sciences. Um aluno procura entre os cadernos embaixo da carteira e pergunta à professora: "É o verde?"

(RAF 6)

Minhas impressões de espanto e confusão quando conheci o número elevado de cadernos e fichários com os quais os alunos franceses tinham que se organizar poderiam, a princípio, revelar apenas um choque de culturas. Minha dificuldade em compreender esse sistema poderia dever-se apenas ao estranhamento oriundo da minha condição de estrangeira. No entanto, a pesquisa desenvolvida por Giguere e Reuter (2003) revela que a tarefa de utilizar os suportes de registro como costumam ser organizados na França é, realmente, bastante complexa. Os pesquisadores entrevistaram 12 alunos de salas de aula CE2 e CM1 e pediram que fossem nomeados e descritos todos os cadernos e fichários utilizados. Nenhum aluno foi capaz de citar espontaneamente todo o conjunto de suportes utilizados. Os alunos erravam e inventavam nomes de cadernos, além de algumas vezes negarem utilizar cadernos de uso corrente em suas classes. Não sabiam dizer para que serviam alguns dos cadernos 
adotados (como por exemplo, o cahier d'évaluation ${ }^{79}$ ), nem diferenciavam os usos entre alguns dos cadernos.

Embora cada escola e cada sala de aula adotem uma divisão um pouco diferente, o número de cadernos utilizados, em geral, é equivalente. Como verificaram Chartier e Renard (2000), a profusão de suportes de escrita, bem como a metódica divisão dos saberes entre eles, é algo que caracteriza o atual ensino francês. A utilização do caderno correto para cada um dos conteúdos é algo considerado importante pelas professoras, que destacam fazer questão de que os alunos adotem sempre o suporte correto para a realização de suas atividades. As autoras atribuem essa preocupação docente a uma "secundarização" do ensino, ou seja, a divisão dos conhecimentos em disciplinas utilizada nas séries mais avançadas passou a ser adotada também nas séries iniciais.

Mais do que uma mera formalidade, a organização dos diversos suportes de escrita compõe o modo pelo qual os alunos formam uma concepção a respeito de cada disciplina, conforme aponta Chartier (2005):

Ao escrever dia após dia, ano após ano, conforme o modo imposto, cada um compõe, de modo permanente, uma certa classificação dos saberes, cujos limites conceituais the são impostos. Seja bemsucedido ou fracassado, a partir dessa rotina, [o aluno] forma uma intuição do que seja história, geografia, gramática. (p.3, tradução minha)

Chartier e Renard (2000), ao identificar a grande preocupação existente nos professores em dividir os conhecimentos em disciplinas, lembram as discussões trazidas pelas correntes da pedagogia que defendem a integração dos saberes e privilegiam a organização das atividades escolares por temas geradores, em vez da subdivisão em disciplinas. Neste ponto, vale retomar a discussão apresentada no capítulo III sobre a divisão em disciplinas dos cadernos brasileiros. Se na França ocorre uma intensa subdivisão dos saberes em disciplinas, pude observar uma situação bastante diversa nas salas de aula brasileiras que conheci. Em vez de muitas subdivisões, são

$\overline{79}$ Caderno de avaliação. 
utilizadas poucas e flexíveis separações, o que constitui, em alguns momentos, uma forma não intencional de interdisciplinaridade.

\section{V.8 OS CADERNOS COMO VITRINES}

Em Chartier e Renard (2000), as autoras utilizam a expressão "vitrines do trabalho da classe" (p.137) para se referirem aos cadernos escolares. A palavra "vitrine" nos remete à idéia de os cadernos reunirem o que se pretende que seja visto, mostrado àqueles que não necessariamente participam do processo de elaboração de tais registros. Sem dúvidas, a expressão "vitrine" também poderia ser aplicada aos cadernos brasileiros, dado que são objetos que se prestam ao controle nas instituições de ensino. No entanto, com base no que observei nas salas de aula francesas, a utilização do termo "vitrines" para designar os cadernos escolares ganhou outra dimensão.

Para abordar essa questão, talvez seja pertinente começar pelo que não é registrado nos cadernos, ou seja, pelo que não se pretende mostrar por meio dessas vitrines.

Acompanhei o recorrente uso de dois suportes de escrita não permanentes: as ardoises e os pedaços de papel. Basicamente, os dois suportes tinham a mesma função, a saber, prestavam-se ao registro fugaz de alguma informação.

As pequenas lousas, chamadas de ardoises, eram amplamente utilizadas pelos alunos para a realização de atividades. A professoras que acompanhei solicitavam o uso desse suporte de escrita especialmente para a disciplina Matemática. As ardoises eram utilizadas para realizar cálculos e fazer atividades das quais participava toda a sala. Gisele, por exemplo, propôs a sua sala de CM 1 um exercício de escrita de números: 
Gisele diz à sala: "Peguem suas ardoises e escrevam em numerais: 'vingt e un million deux mil et dix-huit ${ }^{80}$ '",

Os alunos escreviam cada um em sua pequena lousa. Após algum tempo, a professora solicitava a todos que mostrassem a ela o que tinham feito. Os alunos levantavam suas ardoises com a face escrita voltada para a professora, que ia indicando se estavam corretos ou não os números apresentados pelos alunos. Quando havia erros, ela mostrava na lousa o número correto, indicando em uma tabela a diferença entre milhões, milhares e unidades, desta forma:

\begin{tabular}{c|c|c} 
Milhões & Milhares & \\
\hline 21 & 002 & 018
\end{tabular}

Após apresentar a resposta correta, a professora pedia aos alunos que apagassem suas ardoises e reiniciava o processo dizendo um novo número, como: "six million treize mil et quatre ${ }^{81}$ ".

(RAF4)

As ardoises prestavam-se à realização de atividades rápidas. Os alunos registravam as respostas a uma instrução dada. E logo em seguida, antes de serem apagadas, a professora verificava se estavam certas. Os pedaços de papel, por sua vez, permitiam a condução de atividades menos imediatas, dado que era possível que a professora recolhesse os registros.

Para exemplificar o uso das folhas de papel, voltemos à aula de Claire sobre os estados físicos da água.

Quando a maioria dos alunos termina de copiar, chega um menino com um copo cheio de gelo.

A professora dá início a uma atividade. Explica que vai distribuir pedaços de papel para os alunos. "Quem não acabou, escute as instruções. Vocês podem fazer as duas coisas ao mesmo tempo". Em seguida, Claire explica em que consistirá a atividade: "Vocês devem desenhar um copo cheio de água com gelo dentro".

Um aluno pergunta: “Quanto gelo?”.

Claire: “Um".

(RAF 6)

A intenção de Claire era colocar os alunos diante da questão: qual a posição do gelo dentro da água?

${ }^{80}$ Vinte e um milhões, dois mil e dezoito.

81 Seis milhões, treze mil e quatro. 
Os alunos vão desenhando e Claire avisa que vai recolher as folhas. A professora pede a uma aluna: "Annie, seu desenho". A menina diz que não terminou e conta que vai colorir o desenho. A professora diz que isso não foi pedido.

Logo consegue recolher todos os papéis. A partir dos desenhos feitos, Claire monta uma tabela na lousa, mostrando quantos alunos achavam que o gelo ficaria no fundo, no meio ou na superfície.

Por fim, Claire faz a demonstração com o gelo e a água.

Ao fim da atividade, Claire joga fora todos os papéis com os desenhos dos alunos.

(RAF 6)

Pude acompanhar, algumas vezes, procedimentos semelhantes a esse. Uma determinada questão era feita aos alunos que deviam utilizar o pedaço de papel para responder. As respostas eram recolhidas pela professora que, posteriormente, revelava aos alunos quais seriam as respostas acertadas. 0 que chama atenção é a estratégia de registro utilizada. Em vez de utilizar os cadernos, que seriam um suporte de escrita mais duradouro, são utilizadas as descartáveis folhas. Os cadernos não são considerados os suportes mais adequados para as hipóteses, tentativas ou rascunhos. São espaços reservados ao registro dos conhecimentos mais consolidados, de atividades previamente ensaiadas e corrigidas nos cadernos de rascunhos. Há um esforço para que se tornem materiais de referência, em que os alunos possam encontrar informações que thes sejam úteis futuramente. Dessa forma, não seria interessante haver erros nos cadernos.

Em diversas situações, professoras expressaram o desejo de fazer efetivamente dos cadernos materiais de consulta sobre os conteúdos abordados. Gisele foi com quem pude conversar mais longamente a esse respeito. Ela contou sobre os planos de utilizar os cahiers de histoire e géographie por três anos letivos, do CE2 ao CM2. Além da intenção de criar nos alunos o hábito de retomar o que foi registrado, as professoras desses anos preocupavam-se com o fato de esses cadernos serem subutilizados. Ao final do ano, muitas folhas em branco sobravam, e diversos materiais de referência, tais como mapas e linhas do tempo, eram descartados. Todos esses recursos de apoio 
tinham que ser produzidos novamente. A reutilização dos cadernos seria adotada a partir do ano seguinte, e as professoras começavam a se preparar para isso.

Outro momento representativo da preocupação das professoras francesas com tornar os cadernos materiais de referência ocorreu quando acompanhei uma aula de História na sala de CM2 de Séraphine:

Séraphine diz aos alunos que darão início ao estudo da II Guerra Mundial. Conta que vão estudar o assunto "muito profundamente". Vão ver filmes e reportagens a respeito. Conta que vem se dedicando ao estudo desse tema e por isso quer trabalhar seriamente com eles. Seu interesse em abordar a II Guerra Mundial é tão grande que vão fazer uma quebra na seqüência temporal da história. Até então vinham trabalhando com um momento histórico anterior, e alguns temas relativos ao século XIX terão de ser retomados posteriormente.

Séraphine explica, então, que teriam que pular algumas páginas do cahier de histoire para que não fosse desrespeitada a seqüência cronológica dos fatos. Porém, como não sabem o número exato de páginas que seriam utilizadas, a II Guerra Mundial será registrada nas folhas de fichário.

(RAF 16)

Após essa breve explicação de como iriam trabalhar, Séraphine dá início a uma explanação sobre os antecedentes da guerra. Apresenta os fatos de forma muito envolvente, provocando nos alunos grande curiosidade e interesse. Ao fim da aula, tive algum tempo para conversar com ela e tentei compreender as razões para que fosse tão importante manter nos cadernos a ordem dos fatos históricos. Séraphine voltou a explicar o que tinha dito em sala de aula, parecendo não compreender sequer a razão do meu questionamento. Apenas dizia que iriam usar o fichário, pois não estavam seguindo a ordem cronológica dos fatos. $\mathrm{Na}$ impossibilidade de deixar o número adequado de páginas em branco no caderno, utilizariam as folhas de fichário.

Dessa forma, o modo de utilização dos cadernos que pude conhecer na França formava registros que eram vitrines de saberes e conhecimentos. Como vitrines, apresentavam produtos finais menos marcados pelo processo de ensino-aprendizagem. Com essas experiências, pude compreender o estranhamento de Anne-Marie Chartier quando, em meados de 2005, lhe contei sobre meu projeto de pesquisa. Naquele 
momento, os objetivos de pesquisa ainda eram identificar o que os registros escolares documentavam do processo de ensino-aprendizagem, o cotidiano e a cultura escolar, bem como caracterizar o modo pelo qual tais informações eram registradas. Tal objeto de pesquisa pareceu estranho à pesquisadora francesa. Não the era possível sequer supor que alguém pensasse em um problema de pesquisa semelhante. Ela alegava que os cadernos não poderiam jamais se prestar a tal documentação. Afinal, não havia registros de processos escolares nos cadernos, que eram objetos reservados a ser vitrines das aquisições do aluno.

\section{V.9 ALÉM DAS DIFERENÇAS}

Certamente, os modos de utilização dos cadernos no Brasil e na França apresentam várias diferenças, diferenças ancoradas numa diversidade sóciocultural muito mais ampla do que a mera utilização escolar de suportes de escrita. A descrição dos aspectos que me chamaram a atenção ao longo da etapa francesa da pesquisa centrou-se no que se destacava pela divergência. No entanto, é importante ressaltar que muitas eram as semelhanças.

Ao se observar um caderno francês, é possível identificar várias características semelhantes àquelas que compõem um caderno brasileiro. Em alguns aspectos, aproximam-se tanto daquilo que se concebe, ainda que intuitivamente, como caderno escolar, que, mesmo sem compreender palavra alguma de francês, é possível afirmar que se trata, sem dúvidas, de um caderno escolar.

A presença de textos sobre conteúdos diversos, exercícios, correções feitas pelo professor, a presença do nome e da série para a identificação, uma página inicial reservada a abertura do caderno. São aspectos que compõem os cadernos em 
geral. Foi possível, até mesmo, encontrá-los em cadernos de outras nacionalidades, tais como portugueses, mexicanos e cubanos ${ }^{82}$.

Em cada parte do mundo, em cada país, há aproximações e distanciamentos no modo de compor os cadernos. Muitas das diferenças que podem ser encontradas se devem ao fato de que cada contexto educacional, com suas concepções pedagógicas e regras, imprime características bastante significativas aos cadernos.

Para que se compreenda os conteúdos desses materiais, sempre é necessário analisá-los com base no contexto institucional, educacional e cultural em que tiveram origem.

${ }^{82}$ Foi possível ter acesso a um caderno mexicano, pertencente a uma aluna de escola particular, a um caderno português, de um aluno de escola pública e a um conjunto de cadernos de um aluno cubano. 


\section{CONSIDERAÇÕES E PROPOSIÇÕES}

FINAIS

A pesquisa apresentada nesta tese proporcionou que conhecêssemos cadernos muito variados. Vimos páginas de atividades realizadas com sucesso, outras marcadas pelo fracasso; trabalhos elogiados pelas professoras, outros repreendidos; tentativas bem-sucedidas e outras nem tanto; páginas bonitas, preenchidas com capricho, outras mais despojadas; cadernos preenchidos em conformidade com as regras escolares e outros caracterizados pelas transgressões; produções repletas de criação e outras calcadas na repetição.

Diante da diversidade que vigora quando tratamos de cadernos escolares, voltemos à pergunta inicial desta tese: como a psicologia pode compreender os registros escolares?

Em busca de responder a essa pergunta, foram realizadas as diversas incursões em escolas, no interior das salas de aulas, acompanhando o dia-a-dia do uso dos cadernos escolares e outros suportes de escrita. Considerou-se que, para que cadernos escolares e demais registros escolares fossem utilizados como recursos auxiliares do trabalho do psicólogo, era necessário conhecer como tais materiais se inserem no contexto escolar e passam a fazer parte do processo de ensino-aprendizagem, do cotidiano e da cultura escolar.

O acompanhamento de salas de aula com características diferentes - quanto ao nível de ensino e quanto ao contexto cultural - incrementou consideravelmente a diversidade de materiais encontrada. Tal fato evidencia que, muito além de serem expressões de características individuais e intrapsíquicas daqueles que os produzem - sejam estas de ordem emocional ou neuropsicológica -, os conteúdos dos registros escolares são marcados pelo contexto pedagógico em que são produzidos.

Retomo agora, à luz das informações obtidas e apresentadas neste trabalho, as proposições de Chartier (1999) a respeito de como os suportes de escrita se constituem 
dispositivos no contexto escolar. Como dispositivos, cadernos, provas e folhinhas articulam uma rede formada por instituições, discursos, leis, regras, medidas administrativas, proposições científicas, filosóficas e morais. E todos esses componentes, de alguma forma, comparecem nos registros que são elaborados nas salas de aula.

Esta tese está repleta de exemplos desse fenômeno. A fim de relembrá-los, podem ser citadas as produções de texto precárias de alunos de quarta série, as quais manifestam efeitos de políticas públicas; a forma e os conteúdos das comunicações escritas nos cadernos dos alunos - os bilhetes - forma e conteúdos estes calcados em concepções de educação, valores e modos de funcionamento institucionais. A cada página de caderno novos exemplos se apresentam. Certamente, apesar da intenção e do esforço de contextualizar cada uma das produções, não foi possível esmiuçar como essa rede se configurava em cada caso. Esse é um estudo aqui iniciado e que ainda tem um longo caminho a percorrer.

A oportunidade de desenvolver o estudo no Brasil e na França acrescentou elementos importantes à compreensão de como contextos culturais distintos imprimem peculiaridades aos registros. Ainda que entre dois países haja diferenças realmente evidentes, não são necessárias distâncias físicas tão grandes para ter condições diversas de produção de registros. Até mesmo salas de aula de uma mesma escola podem adotar modos diversos de registrar.

Além de todos os aspectos contextuais, as produções escolares carregam também marcas individuais daqueles que as realizam. Alunos e professores têm possibilidades de expressão mediadas pelos suportes e pelas atividades escolares. Os cadernos e demais suportes de escrita são sempre espaços de expressão delimitados, inseridos no contexto sociocultural em que são utilizados.

A realização de registros na escola implica aprendizagens diversas. Para utilizar com desenvoltura a prática de registrar, é necessário conhecer, além das letras, das correspondências grafema-fonema e das regras de ortografia, qual é a cor adequada, o tamanho da letra, qual caderno deve ser usado. Os suportes de registro configuramse, dessa forma, como espaços de inserção na cultura escolar. Estar inserido na 
cultura escolar possibilita tanto o exercício de uma conformidade com o que está estabelecido quanto os atos insubordinados. Os suportes de registro são, pois, cenário para diversas táticas ${ }^{83}$ praticadas pelos alunos.

Nesse jogo de ora proceder conforme o estabelecido, ora burlar as regras, ora buscar modos aceitáveis de transgredir, os alunos vão assumindo os suportes de escrita. Mais: vão fazendo deles registros de conteúdos escolares, tentativas, hipóteses, situações vividas, amizades, emoções.

Ao registrar uma gama tão ampla de conteúdos, relações, fenômenos e circunstâncias, os registros escolares raramente são decifráveis com facilidade. Nas páginas dos cadernos aparece um emaranhado de vestígios que só podem ser compreendidos com base em uma cuidadosa análise do contexto em que os registros foram produzidos.

As figuras de páginas de cadernos apresentadas na introdução desta tese, acrescidas das situações e relações vividas por Severino, Mateus e Ralph exemplificam como conclusões que desconsideram as condições de produção dos registros podem ser errôneas. Esses três alunos, assim como os demais presentes neste trabalho, nos possibilitaram apreender que a compreensão dos registros produzidos na escola exige que se atente para aspectos diversos, tais como: o grau de familiaridade que o aluno tem com a realização de registros, o nível de alfabetização, as relações envolvidas no ato de registrar, as regras vigentes na instituição de ensino, as intenções do aluno ao realizar o registro.

\section{VI.1 UMA PROPOSTA DE OLHAR}

Caminhando para encontrar maneiras cada vez mais adequadas de compreender os registros produzidos na escola, em especial os cadernos, apresento algumas sugestões. Não há a intenção de apresentar um protocolo de análise, mas

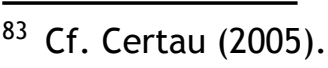


algumas indicações que buscam adotar um referencial crítico para a compreensão das produções escolares.

Os cadernos e demais registros escolares podem ser úteis instrumentos para o diagnóstico e a intervenção em questões escolares. Não são, porém, documentos que falam por si, ou que contenham informações facilmente dedutíveis para olhares experientes ou tecnicamente bem preparados. Apesar disso, podem ser utilizados como importantes instrumentos diagnósticos, se, em vez de serem tomados como materiais repletos de respostas sobre a criança e a sua situação escolar, forem vistos como importantes desencadeadores de perguntas.

Tendo em mente que os cadernos pertencem ao aluno, é importante que seja com a sua concordância que o psicólogo tenha acesso a esse material. Muitas vezes a criança não se sente à vontade em expô-los, especialmente quando as produções escolares representam para o aluno o não-saber e fracasso na escola. Nesse caso, pode ser pertinente buscar outras formas de aproximação. Conforme aponta Moysés (2001), uma mesma característica, habilidade ou capacidade pode ser expressa de modos diversos em diferentes situações. Uma criança pode, por exemplo, saber escrever, ter conhecimentos matemáticos, capacidade de organização, coordenação motora, expressando isso ou não nos cadernos. Assim como conhecimentos ainda não adquiridos podem fazer parte, de modo impecável, do conteúdo desses materiais, há casos de alunos copistas, que se encontram num estágio muito inicial de alfabetização, mas que têm cadernos completos, bem apresentados e com atividades realizadas com perfeição. Certamente há modos de organização das atividades em sala de aula que facilitam isso, enquanto outros inviabilizam. Dessa forma, convém sempre verificar como aquilo que o caderno nos faz supor, do ponto de vista clínico, se manifesta em outros contextos e em outras situações, considerando tanto o processo de escolarização quanto outros espaços culturais e sociais.

Sadalla, Bariani e Rocha (1999), ao dar indicações para a análise de material escrito, enfatizam pertinentemente a importância de que a criança seja ouvida e possa comentar o seu próprio material e produções. Desse modo, é possível: compreender 
o que seleciona de seu trabalho como sendo bom ou ruim; quais são os critérios que julga serem os mais importantes ao trabalhar com os cadernos - estética, qualidade da letra, realização correta das atividades, recebimento de menções de aprovação da professora, dentre outras; obter informações sobre as situações em que determinadas atividades foram realizadas; ouvir comentários sobre aspectos diversos dos cadernos. É possível, ainda, que o diálogo com base nos materiais escolares traga elementos sobre a relação com a escola, os colegas, o professor, a família. Ou seja, o caderno pode ser um importante mediador nas conversas com a criança, possibilitando o acesso a informações referentes, direta ou indiretamente, à sua escolarização.

Algo bastante importante oferecido pelos cadernos é a existência de produções realizadas ao longo de um determinado tempo. Tal característica permite observar oscilações de desempenho, progressos, retrocessos ou estagnações ${ }^{84}$. Mais do que constatar esses processos, seria fundamental investigar em que situações acontecem. Como a criança se sai em diferentes tipos de atividades (cópias, produções mais livres, diferentes disciplinas etc.). Houve mudança de procedimento do professor?

\section{VI.1.1 CONTEÚDO DOS CADERNOS}

É importante que o psicólogo investigue em que condições foram elaboradas as diferentes atividades que são apresentadas. Há formas de organização da atividade didática que possibilitam ao aluno copiar quase a totalidade dos conteúdos e das resoluções de exercícios de uma disciplina. Então, um dos aspectos relevantes é diferenciar aquilo que foi realizado por meio de cópias e o que foi uma produção mais autônoma do aluno.

As atividades produzidas de modo mais autônomo podem trazer informações sobre aquilo que o aluno domina. As cópias também podem trazer elementos

\footnotetext{
${ }^{84}$ Em diversas culturas, como pude observar mais diretamente nos cadernos brasileiros, franceses e portugueses, os cadernos utilizados no princípio do ano, em geral, revelam atividades realizadas com maior esmero, o que resulta em trabalhos mais organizados e com uma apresentação estética mais cuidada. Esse fenômeno também é freqüente com cadernos enquanto novos.
} 
interessantes, sobretudo nos erros que revelam. Por exemplo, quando uma criança copia cometendo um erro ortográfico (tal como escrever a palavra "acidente" como “assidente"), é possível supor que ela já tenha feito importantes aquisições nesse campo de conhecimento. Afinal, em vez de apenas reproduzir letras apresentadas na lousa, realiza uma operação que envolve os sons da palavra copiada.

0 conteúdo dos bilhetes encontrados nas páginas dos cadernos também pode ser revelador, dando possivelmente indícios das exigências que vigoram em sala de aula, da relação entre o professor e o aluno, bem como das estratégias que vêm sendo adotadas pelo professor em sala de aula para lidar com as dificuldades.

Ainda que as atividades registradas nos cadernos não possam ser consideradas documentos que revelem fielmente as práticas pedagógicas adotadas e nem os conteúdos abordados em sala de aula, podem dar indícios de como são organizadas as atividades didáticas em sala de aula. Por meio dos registros, é possível conhecer quais são as estratégias que o professor utiliza para ensinar. Serão as atividades propostas interessantes ou desinteressantes para o aluno? Variadas ou repetitivas? Adequadas ou não ao nível de conhecimento do aluno? Um exemplo recorrente se apresenta nas queixas escolares de crianças que passam a aula distraídas ou que se mostram indisciplinadas, enquanto seus cadernos revelam a solicitação de atividades que requerem a interpretação de textos, apesar de ainda se iniciarem no processo de aprendizagem da leitura e escrita.

\section{VI.1.2 CONVERSA COM O PROFESSOR}

Como os registros realizados na escola não falam por si mesmos, é importante conversar com aqueles que fazem parte direta ou indiretamente dessas produções, os professores. 0 diálogo com a escola tem se revelado uma das estratégias fundamentais para a compreensão e intervenção em casos que incluem questões escolares, e os cadernos escolares podem intermediar o diálogo. 
É importante possibilitar que o professor comente as produções de seu aluno. Quais considera boas? Com quais não ficou satisfeito? Por quê? A possibilidade de conversar com o professor a respeito do material pode ser um momento fundamental para compreender em que situações as produções se deram; para conhecer qual é o seu modo de trabalhar com a sala de aula e, em especial, com a criança em questão, a fim de investigar quais são as estratégias que utiliza. Também pode ser um momento oportuno para compreender situações que levaram o professor a escrever bilhetes. Como os bilhetes são, em geral, direcionados aos pais, podem possibilitar que sejam tematizadas as concepções que o professor tem a respeito da família da criança e qual é a relação que estabelece com ela.

Verificar materiais de outros alunos da mesma sala de aula pode ajudar a compreender quais são as regras e as exigências vigentes na sala de aula. Permite, ainda, reunir elementos para avaliar como está o aluno em questão em relação aos demais alunos da classe.

O momento de conversa com o professor pode ser relevante também do ponto de vista da intervenção em relação à queixa escolar. 0 atendimento clínico já pode ter revelado elementos importantes para discutir e problematizar com o professor. Produções que se diferenciem do que comumente é apresentado pelo aluno em seus cadernos, por exemplo, podem ser ricas para produzir reflexões.

Assim, as produções escolares podem ser recursos auxiliares muito úteis na tarefa de obter informações a respeito da criança e de sua situação escolar. Isso, porém, não é um procedimento simples. Como diz Deleuze:

Desemaranhar as linhas de um dispositivo é, em cada caso, traçar um mapa, cartografar, percorrer terras desconhecidas, é o que Foucault chama de "trabalho em terreno". É preciso instalarmo-nos sobre as próprias linhas, que não se contentam apenas em compor um dispositivo, mas atravessam-no, arrastam-no, de norte a sul, de leste a oeste ou em diagonal. (1989, p.185, tradução minha) 


\section{VI.2 FINALIZANDO}

Esta tese foi elaborada com o intuito de constituir referenciais para a compreensão, do ponto de vista da psicologia escolar crítica, dos registros - elaborados prioritariamente pelos alunos. Em busca desse propósito, foi desenvolvido um longo trabalho de pesquisa em salas de aula diversas.

As informações obtidas indicam que os cadernos escolares, se compreendidos como produções unicamente da criança, por meio de análises que os descontextualizam e desconsideram o conjunto de relações e questões institucionais em meio às quais são produzidos, podem conduzir a interpretações errôneas. Não é possível compreender cadernos e demais registros realizados na escola somente por aquilo que apresentam em si. É preciso realizar umaanálise que faça desse material um conjunto de indícios, pistas iniciais que devem ser averiguadas cuidadosamente.

Com certeza, é impossível ter acesso a todas as informações de como os cadernos são produzidos na escola. No entanto, essa impossibilidade, em vez de paralisadora, deve ser instigadora na busca de informações que transcendam as aparências imediatas e que auxiliem a problematizar aquilo que nos é apresentado na forma de registro. Dessa perspectiva, os cadernos podem constituir úteis recursos de avaliação e intervenção clínicas, permitindo a aproximação e a investigação das questões escolares.

Por ora, foram apresentados alguns referenciais para que psicólogos possam utilizar os registros produzidos na escola como ferramentas em seu trabalho. As sugestões aqui apresentadas - fruto de um trabalho de inserção em salas de aula e acompanhamento dos processos pelos quais tomam forma cadernos e demais registros - são apenas diretrizes iniciais para uma tarefa que ainda requer mais estudos. 
ANEXOS 


\section{ANEXO A \\ RELAÇÃO DAS OBSERVAÇÕES EM SALA DE AULA}

\begin{tabular}{|l|l|l|}
\hline & Data & Duração \\
\hline RA-01 & $03 / 03 / 2004$ & $2 \mathrm{~h} 15$ \\
\hline RA-02 & $12 / 03 / 2004$ & $2 \mathrm{~h} 30$ \\
\hline RA-03 & $19 / 03 / 2004$ & $2 \mathrm{~h} 30$ \\
\hline RA-04 & $26 / 03 / 2004$ & $1 \mathrm{~h} 40$ \\
\hline RA-05 & $16 / 04 / 2004$ & $3 \mathrm{~h}$ \\
\hline RA-06 & $23 / 04 / 2004$ & $2 \mathrm{~h}$ \\
\hline RA-07 & $30 / 04 / 2004$ & $1 \mathrm{~h} 45$ \\
\hline RA-08 & $14 / 05 / 2004$ & $2 \mathrm{~h} 10$ \\
\hline RA-09 & $21 / 05 / 2004$ & $2 \mathrm{~h} 00$ \\
\hline RA-10 & $28 / 05 / 2004$ & $1 \mathrm{~h}$ \\
\hline RA-11 & $04 / 06 / 2004$ & $1 \mathrm{~h} 20$ \\
\hline RA-12 & $09 / 06 / 2004$ & $2 \mathrm{~h}$ \\
\hline RA-13 & $16 / 06 / 2004$ & $2 \mathrm{~h} 30$ \\
\hline RA-14 & $23 / 06 / 2004$ & $2 \mathrm{~h}$ \\
\hline RA-15 & $02 / 07 / 2004$ & $2 \mathrm{~h}$ \\
\hline RA-16 & $06 / 08 / 2004$ & $1 \mathrm{~h} 30$ \\
\hline RA-17 & $13 / 08 / 2004$ & $2 \mathrm{~h}$ \\
\hline RA-18 & $19 / 08 / 2004$ & $2 \mathrm{~h} 30$ \\
\hline RA-19 & $26 / 08 / 2004$ & $1 \mathrm{~h} 45$ \\
\hline RA-20 & $03 / 09 / 2004$ & $1 \mathrm{~h} 40$ \\
\hline RA-21 & $09 / 09 / 2004$ & $2 \mathrm{~h} 30$ \\
\hline RA-22 & $16 / 09 / 2004$ & $1 \mathrm{~h} 30$ \\
\hline RA-23 & $23 / 09 / 2004$ & $1 \mathrm{~h} 40$ \\
\hline RA-24 & $30 / 09 / 2004$ & $1 \mathrm{~h} 30$ \\
\hline RA-25 & $07 / 10 / 2004$ & $1 \mathrm{~h} 40$ \\
\hline RA-26 & $14 / 10 / 2004$ & $2 \mathrm{~h}$ \\
\hline RA-27 & $28 / 10 / 2004$ & $1 \mathrm{~h} 40$ \\
\hline RA-28 & $05 / 11 / 2004$ & $2 \mathrm{~h}$ \\
\hline RA-29 & $11 / 11 / 2004$ & $2 \mathrm{~h} 20$ \\
\hline RA-30 & $18 / 11 / 2004$ & $1 \mathrm{~h} 30$ \\
\hline RA-31 & $06 / 12 / 2004$ & $2 \mathrm{~h} 30$ \\
\hline RA-32 & $10 / 12 / 2004$ & $1 \mathrm{~h} 45$ \\
\hline Duração total & & $55 \mathrm{~h} 25 \mathrm{~min}$ \\
\hline & & \\
\hline
\end{tabular}




\section{ANEXO B \\ EXEMPLO DE RELATO AMPLIADO}

\section{RA-30 18.11.2004}

Ontem, eu havia ligado para a escola para lembrar os alunos da entrevista. Falei com Sandra, a diretora da escola. Ela disse que pediria a alguém para avisar na sala. A princípio, antes que eu falasse o nome dos alunos que iriam participar, Sandra perguntou se seriam apenas o Ralph e o Igor. Expliquei que não pretendia falar com eles no dia seguinte, mas sim com Fabiana, Alex, Uelinton e Jordan. Sandra anotou e, hoje, pelos comentários dos alunos percebo que, realmente, eles foram avisados.

9:10h Eu e Natali chegamos um pouco atrasadas, preocupadas. Assim que nos aproximamos da escola, após atravessar um percurso de barro escorregadio, vemos Alex e Fabiana na frente da porta da escola. Pedimos desculpas pelo atraso e Alex diz que tinha chegado fazia pouco tempo, Fabiana tinha chegado primeiro. Fico contente por ver que tudo tinha dado certo. Na semana passada, eu não tinha conseguido falar diretamente com Fabiana, pois ela tinha faltado. Agora, ela lá estava. 0 compromisso que os alunos têm demonstrado com as entrevistas tem me surpreendido.

Enquanto nos encaminhamos para a sala, pergunto se eles fazem grupo de apoio e eles dizem que não, nenhum deles. Logo encontramos Célia, que conversava com um aluno, me aproximo e aguardo um pouquinho. Ela me cumprimenta e logo diz que a sala do grupo de apoio está disponível. Aviso que vou entrevistar Alex e Fabiana agora (eles estão ali, pertinho de nós), depois virão Jordan e Uelinton. Carla diz não saber quem são.

Vamos para a sala e Fabiana me avisa que Uelinton não vai poder vir, pois está na peça de teatro. Ele estaria caracterizado e, por isso, não poderia vir. 
Logo começamos a entrevista. Eu apenas filmo um pouquinho e mostro a eles, nos organizamos no espaço e começamos.

Definitivamente, esta foi uma entrevista tranqüila, produtiva, centrada no assunto proposto por mim. A princípio, eles pareciam um pouco incomodados, intimidados pela câmera. Alex, por exemplo, mantinha o seu caderno embaixo da carteira, onde não podia ser filmado. Mas aos poucos foram ficando à vontade. Pedi a Alex para colocar o caderno em cima da mesa e ele colocou. A relação entre a dupla também me pareceu muito boa. São amigos, já viveram algumas coisas juntos. Mas, ao mesmo tempo, tinham algumas experiências diferentes que possibilitaram que mostrassem visões diferenciadas sobre fatos.

A demora para que a entrevista realmente 'engrenasse' acabou fazendo com que eu decidisse levá-la um pouco adiante no horário. Afinal, Jordan e Uelinton ainda não tinham aparecido. Encerrada a entrevista com eles, arrumam as suas coisas. Alex diz não saber se voltará para a aula mais tarde. Está com sono. Vai dormir um pouco.

Eu os acompanho até o lado de fora da sala, para ver se vejo Jordan, se consigo falar com Uelinton. Nada de Jordan. Uelinton está na coxia do teatro, completamente inacessível. Alex assiste um pouco da peça antes de ir embora. Pergunto a ele se teria visto Jordan. Ele diz que não. Vejo também Valéria, e estranho o fato de ela estar na escola de manhã. (Depois, encontrei um bilhete no caderno dos alunos comunicando que haveria uma reunião entre ela e os pais, nesta quinta-feira, às 7:30h da manhã.) Saio pela escola procurando, e, depois de um tempo, reencontro Alex que está na porta da escola. Ele me avisa que Jordan está vindo. Volto para a sala onde as entrevistas vêm sendo realizadas e fico esperando. Nada de Jordan. Volto a sair, para dar uma volta na escola, para ver se o encontro, mas nada de encontrá-lo. Volto para a sala e lá está ele, todo molhado, roupa molhada, cabelo molhado. Já conversava com Natali. Conta que caiu na quadra, mostra o cotovelo machucado. Diz que não poderá ficar para a entrevista, parece chateado. Ficamos tentando combinar como faríamos. Duas possibilidades: marcar outro dia ou esperar que ele voltasse. Jordan 
disse que não demoraria muito. Penso que talvez seja a solução ideal, pois Uelinton também estava preso na peça ainda.

Jordan vai tomar banho e eu e Natali vamos ver a peça: Os Saltimbancos. Alcina, professora da escola, está como jumento. Outras professoras que não conheço também atuam. Cássia, que eu conheço há anos, assiste e parece controlar a música. Ela continua na coordenação dos projetos Teatro e Brinquedoteca.

Uelinton entra apenas no final da peça, como que numa dança final, ele é um dos pequenos jumentos. Parece contente de participar, quando me vê, ainda lá do palco, abre um grande sorriso para mim. Ficamos aguardando, afinal Jordan ainda não tinha aparecido. Imaginei que Uelinton estaria livre agora, mas não foi o que aconteceu. Cássia conversou por cerca de 10 minutos com eles, elogiou o desempenho na peça. Dizia que quando estavam no palco não era mais eles próprios, mas os personagens que representavam. Para dizer isso imitava um pouco de cada personagem. Foi perguntando o nome de vários alunos para dizer que eles não eram mais os seus próprios nomes. Deu uma bronca no comportamento deles na coxia. Avisou que seria servido um lanche para eles e que depois à tarde se apresentariam de novo.

Cássia me vê no final de sua fala, e vem logo me cumprimentar. Parece bastante feliz em me ver, diz que sonhou comigo naquela noite mesmo e me dá um forte abraço. Também fico contente por vê-la. Havia mais de um ano que não a encontrava. Pergunta o que estou fazendo por ali e conto que estou fazendo a pesquisa de doutorado. Pergunta por uma amiga que temos em comum. Pergunto como é que estão as coisas. E ela conta que estão com 3.600 crianças nos Projetos Teatro e Brinquedoteca. Pergunto como ficará a continuidade dos projetos na próxima administração e ela parece animada. Diz que acha que vão continuar, sim. São projetos que têm tido uma participação muito grande, falou do aumento no número de multiplicadoras. Diz que está montando uma espécie de relatório para entregar. Mas, diz que o que importa para eles são os números. Pergunto se ela quer continuar na coordenação e ela diz que sim. Comento que iria entrevistar um dos meninos que participava da peça e, 
muito prestativa, Cássia pergunta o nome dele. Vai até o palco e providencia que Uelinton me acompanhe.

Ele vem todo contente. Faço algum comentário elogioso sobre a peça e ele faz uma expressão contente. Comenta que hoje tinha umas 5 coisas para fazer, tinha que sair com a sua mãe, ir à casa de sua tia, tinha a entrevista, mas acabou não conseguindo fazer nada por causa da peça. Estranho um pouco esse comentário de Uelinton. Tudo fará sentido algumas horas depois, quando Malu vai me contar que os pais de Uelinton são cegos e que é ele quem os acompanha para tudo.

Aproximadamente 11:30h Eu pretendia começar a entrevista com Uelinton e quando Jordan chegasse se juntaria a nós. No entanto, logo Jordan chegou. Comentou que ainda estava com uma certa dor na cabeça, mas que não havia ferida. Eles se ajeitam nas cadeiras da sala e nós pedimos a eles que fiquem nas carteiras que separamos para as entrevistas.

Perguntei se eles já tinham sido filmados e Uelinton contou que já tinha aparecido na TV por causa de uma entrevista. Perguntei o que ele tinha dito e ele contou que não tinha dito nada, apenas a sua mãe tinha falado. Fizemos como de costume: filmamos um pouquinho e depois mostramos a eles. Jordan disse que tinha saído muito feio.

A entrevista transcorreu de um modo bastante conturbado, especialmente pela forma como Jordan lidava com a câmera. Ele parecia um tanto fascinado por ser filmado, então ficava todo o tempo buscando chamar a atenção da câmera, queria mostrar o caderno, levantava-se. Mesmo quando Uelinton falava, Jordan continuava buscando a atenção da câmera, atrapalhando um pouco a dinâmica da entrevista. Foram raros os momentos de interação. A entrevista acabou tendo de ser interrompida, pois Jordan estava com fome e Uelinton também. A possibilidade de que eles comessem na própria escola facilitaria a continuidade, afinal eles poderiam comer e nós continuarmos em seguida. No entanto, Uelinton vai se informar e lhe dizem que a comida acabou, ele terá que retornar à sua casa. Interrompemos a 
entrevista e combinamos continuar na semana que vem. Uelinton ainda tenta combinar para hoje mesmo, após a peça. Eu digo que não poderia. Além disso, eles estariam em aula e eu não gostaria de retirá-los da aula.

Peço a eles os cadernos emprestados, para que eu xerocasse. Uelinton me empresta sem problema algum, assim como Fabiana e Alex tinham feito. Jordan, a princípio, me empresta, mas depois me ouve dizer a Uelinton que eu iria fazer cópia (Eu já tinha dito isso antes a ele.). Então, Jordan diz que não quer que seja feita cópia de seu caderno. Eu penso que não posso perder a oportunidade de levar o caderno dele e pergunto, então, o que exatamente ele não quer que eu copie. Diante disso, ele diz que não quer que mais ninguém na escola veja, apenas eu. Eu me comprometo a não mostrar seu caderno a ninguém da escola e ele permite que eu leve seu caderno.

Vamos embora. Uelinton e Jordan nos acompanham. Jordan nos acompanha só um pouquinho. Uelinton nos acompanha bem mais, até à linha do trem. Enquanto caminhamos, conversamos um pouco sobre a vida escolar de Uelinton. Pergunto se ele sempre estudou naquela escola e ele conta que sim, depois diz que fez a préescola em um outro lugar que não entendo bem onde é. Pergunto se é na escolinha da Jane e ele diz que não. Interessante que eu me lembro de ter ouvido falar muito lá, na escolinha da Jane, sobre um casal de cegos que tinha filhos. Já não me lembro bem, mas tive a impressão, em 98, de que ao menos uma das crianças estudava lá.

Pergunto se ele sempre morou ali e Uelinton conta que morou em Araras, diz que seu pai mora lá. Conta que lá é mais tranqüilo, não tem tanto carro passando (Uelinton mora exatamente às margens do asfalto). Tem amigos por lá e sempre volta. Fala também de sua terra 'natal', como ele próprio diz, a Bahia. Conta que gostaria de ir pra lá, conta que não conhece. Era muito pequeno quando sua família veio. Logo chegamos à sua casa.

14:40h Após longas horas no xerox - onde ouvimos o comentário de que os cadernos dos alunos da quarta série pareciam ser de primeira série, pois eram muito 
desorganizados; e providenciamos a (DEMORADA!!!!!!!!!) cópia de todo o material cedido pelos alunos - conseguimos voltar à escola. A idéia era apenas devolver o material aos alunos, marcar a continuação da entrevista com Jordan e Uelinton, e marcar a entrevista com Leonardo e Cleber. Porém, quando chegamos à escola, os alunos estavam no teatro. A peça "Os saltimbancos" tinha começado havia pouco. Se não me engano, a galinha acabava de se apresentar. Vamos até perto de Malu. Sento-me ao lado dela, Natali ao meu lado. A peça está bem montada, as professoras capricharam na produção das fantasias e nos ensaios. É admirável o resultado, considerando que não são profissionais de teatro. As crianças da escola, que fazem parte do projeto teatro, participam de partes musicais da peça. Cada grupo representa um dos personagens. Os alunos que assistem parecem interessados. A platéia fica em silêncio, presta atenção. Riem, batem palmas nas músicas. Parecem muito atentos. Ocorreu até uma brincadeira interessante. Na peça, os quatro animais identificam os seus patrões ao fundo do teatro, ou seja, exatamente onde está sentada Malu. Alguns alunos brincam com ela dizendo que ela é a patroa.

Malu, por sua vez, parece muito cansada. Está quase dormindo durante a peça. Chega a comentar que não agüenta ficar muito tempo parada, mesmo. Algo é dito na peça sobre estar desclassificado e Malu comenta comigo que quem estava desclassificada era ela. Irritava-se quando os alunos, nas músicas, em vez de apenas bater palmas, batiam nas carteiras. Conta-me sobre uma situação em que fizeram isso na sala de aula. Reclama sobre o fato de os alunos não terem se sentado apenas de um dos lados do teatro, como ela havia pedido. Jackson pede para ir beber água, no meio da peça, e Malu não permite.

Quando a peça acaba, os alunos se levantam. E vão saindo do teatro. Chamo Jordan para devolver-lhe seu caderno (o que está em uso) e perguntar se poderia entregar o outro (já preenchido) na próxima semana. Ele diz bastante sério que tudo bem. Mostra-me um bolo de figurinhas do Yu-Gi-Oh, bem grande. A expressão de Jordan é, nesse momento, extremamente séria. Pergunto a ele se está tudo bem, se aconteceu algo, e ele responde que está tudo bem, sim. Porém, sua resposta 
não parece (nem a mim, nem a Natali) ser verdadeira. Vamos saindo do teatro meio junto de Cleber. Ele conta que só não foi chamado para participar da peça pois tinha faltado na quinta-feira, dia em que a professora escolheu os participantes. Ele seria o jumento. Conta que tinha ensaiado todas as falas, estava sabendo tudo. Parecia um pouco chateado por não ter participado. Combinamos sobre a entrevista. Será na próxima quinta-feira, em sua casa. Nos encontraremos na escola para ir.

Converso também com Leonardo, que apenas aceita, sem comentários, o que proponho. Fica tudo combinado.

15:20h Entramos na sala, que ficará bastante agitada por todo o tempo de nossa permanência. A sala está repleta como raramente. Não havia sequer nenhuma carteira disponível para que nos sentássemos. Os alunos se movimentam para que tenhamos lugares, arrumam cadeiras. Não sei se a "razão" para que Ralph se sentasse junto com Jennifer foi essa. Mas, o fato é que ele deixou sua carteira livre e sentou junto a carteira de Jennifer, tendo lá ficado todo o tempo. Ralph tem, realmente, o hábito de se sentar com outros alunos. É comum sentar-se com Juarez, por exemplo. Porém, havia um clima explícito de paquera por parte de Ralph. Como Jennifer estava exatamente de costas para mim, não consegui vê-la muito bem, não sei o quanto ela também paquerava e aceitava ser paquerada.

Ralph está com um caderno de Alex e faz que o rasga. Alex faz um cara de bravo e Ralph the devolve o caderno.

Já há algumas contas na lousa, parece uma atividade iniciada antes que eles saíssem para o teatro.

Alex escreve na lousa, faz um coração com as letras R e T (ver o desenho no caderno de anotações)

Uelinton entra na sala, todos os alunos já lá estavam havia algum tempo. Conversa com a professora, parece que ele não pode ficar na sala. Malu diz algo a ele sobre ter vindo só para o teatro e não para a aula. Não está brava por isso, parece compreensiva. 
Edieverson, que também participava da peça, entra na sala.

Alan apaga a lousa. Leonardo passa e bate nele.

Malu anuncia: "Vou corrigir na lousa"

Ralph reclama: “Ah, não". Percebo que ele e Jennifer ainda estão terminando de fazer.

Uelinton volta para a sala (parece que ele tinha ido justificar a sua saída para a direção). Pega suas coisas. Chamo Uelinton para que ele venha ate mim. Ele vem, me dá um abraço. Devolvo seu caderno. Tento devolver a prova, mas ele diz: “É da professora". Combinamos continuar a entrevista na próxima quinta-feira às 9h.

Heitor mostra seu caderno a Malu

Malu dá uma severa bronca em Jordan. Não sei o que estava acontecendo, mas tudo girou em torno das figurinhas do Yu-Gi-Oh. Malu pega as cartas de Jordan. A professora está muito brava, grita com Jordan, a sala pára. Malu: "Abre o caderno e copia essas contas agora! (...) Se não tiver com essas contas no caderno, vai lá com a Célia. Tem 5 minutos." Não cheguei a ver, enquanto estive na sala, que Jordan fizesse algo em seu caderno. Malu chegou a cobrar dele mais uma vez, mas também não fez mais que isso. É interessante que a ameaça é Célia, a vice-diretora, e não Sandra, a diretora. Imagino que a vice seja mais responsável pela disciplina.

Malu se aproxima de mim. Fala para mim, mas suficientemente alto para que os alunos ouçam: "Não dá pra dar aula com essas figurinhas." Me pergunta: "Você já viu essas figurinhas?” Digo algo como já dei uma olhada. E Malu começa a dizer “maldição", referindo-se às figuras que aparecem nelas. Um pouquinho depois, Ralph vem me mostrar uma de suas figurinhas, mostra uma cujo título é réptil. Aparece nela uma tartaruga, me parece uma tartaruga gigante. Já vi também algumas que representam partes do corpo de uma espécie de robô. 0 que sei é que a discussão sobre essas figurinhas é bem mais ampla. Adoradas pelas crianças, esas figurinhas, em geral, são malvistas pelos adultos.

Jordan está com seu caderno aberto, apóia-se sobre ele, os olhos muito vermelhos. 
Estão 31 alunos na sala. Só sinto falta de Uelinton.

Ralph e Jennifer fazem as contas. Olham a tabuada.

Jordan fica abrindo uma carta, parece uma conta de luz ou algo assim. Juarez copia.

A professora auxilia Jackson a fazer uma conta.

Havia muito tempo que eu não acompanhava uma aula de matemática de Malu. (Nem me lembro da última que acompanhei.) A dinâmica é um pouco diferente das aulas de português. Malu vai passando pelas carteiras e parece ser mais solicitada pelos alunos.

Igor desenha algo na lousa. Inicialmente me parece um coração. Malu the dá uma bronca: "Igor, ô Igor”. Ele vai fazer no cantinho da lousa, próximo à porta e leva nova bronca. Algum dos alunos perguntam o que ele está fazendo e ele diz que é uma luva de boxe. Realmente, agora que ele conta, parece uma luva de boxe. É uma forma de fazer corações...

Ralph mostra aos colegas, em especial a lgor, uma folha repleta de desenhos de corações estilizados. É uma página de seu caderno. Ele afirma ter sido ele quem desenhou. Igor duvida: "Lógico, você copia dos cadernos que acha na reciclagem" (Imagino que a família de Ralph trabalhe com reciclagem. Realmente, tenho visto sempre muitas garrafas PET no quintal). Ralph diz que não copia. Alan interfere em sua defesa, contando que Ralph já fazia isso na primeira série. Depois, Alan chega a se questionar se foi realmente na primeira série que estudaram juntos. Ralph continua folheando seu caderno, e mostra agora outro desenho - de um herói de desenho japonês (me parece ser) -, e desafia: "Fala que não fui eu”. Mostra vários outros desenhos e continua desafiando: "Fala que não fui eu".

Igor está com as figurinhas Yu-Gi-Oh.

Alan fica rindo com Ralph.

Percebo que Suzane tem sua prova consigo

Lauriane faz as suas contas

Jordan ainda nada faz. 
Malu vai passando pelas carteiras e auxilia Talita (grande).

Talita (pequena) entrega sua prova

Algo que eu pretendia compreender, mas que acabei nem sequer perguntando a Malu, foi a razão pela qual alguns alunos ficaram com suas provas e outros não. $\mathrm{Na}$ entrevista, Alex relatou ter pedido a prova e Malu, e a professora não deixou a avaliação com ele. No entanto, vejo que diversos alunos ainda estavam com suas provas. $\mathrm{O}$ fato de eu perceber que as provas estão apenas com os bons alunos seria uma mera coincidência?

Cristiano e Edieverson fazem as contas, estão sentados juntos. Cleber, em pé ao lado da carteira deles, observa.

15:40h Ralph avisa Malu : "Professora, já passaram 10 minutos" Parece-me que ele se referia à contagem de tempo imposta por Malu a Jordan. Bem se sabe que Ralph, assim como Igor, não gostam de Jordan. Eles ficaram bastante contentes por ver o "inimigo" nessa difícil situação.

Malu olha o caderno de José, escreve algo. Faz o mesmo no caderno de Cláudio.

Igor vai sentar-se na cadeira de Malu, fica algum tempo em sua mesa.

Ralph e Jennifer continuam juntos. Ralph parece estar todo o tempo se fazendo charmoso e interessante.

Malu passa por mim e comenta: "Dia de matemática é essa loucura aqui."

Diego chama Malu e pergunta "É esse número aqui?"

Igor vem até a minha mesa e me mostra um bilhete. Conta que a professora escreveu no dia em que estive lá pela última vez. 
Elis, hoje o lgor brigou de tapas na sala de aula. Gostaria que soubesse que apesar do outro aluno ter ido até onde ele estava, ele chamou o menino de ladrão e por isso ele disse que brigou com ele.

Oriente lgor a ser mais tolerante pois sinto muita violência nas atitudes dele.

Atenciosamente, Profa. Malu

Favor assinar o bilhete

Hortolândia, 10/10/04

Copio o bilhete e o levo para Igor novamente. Aí, pergunto a ele com quem tinha brigado. Igor conta que foi com Jordan. Depois de descrever a briga em si - bateu aqui, bateu lá -, Igor diz que Jordan é ladrão mesmo. Conta várias situações em que ele teria roubado coisas de alunos: roubou suas cartas e chegou a roubar um bombom da professora. Diz que ele se justifica, inventa uma história e todos acreditam. Mas Igor não acredita, sabe que ele é ladrão. Pergunto a lgor se ele mostrou o bilhete a sua mãe, e ele diz que não. Não mostrou nem irá mostrar. Alan, que está imediatamente atrás de Igor, entra na conversa e diz que mostra os bilhetes para sua mãe. Pergunto por que e ele diz que se não mostrar: [“Apanha duas vezes. Por não ter mostrado e por ter feito bagunça."]. Pergunto se ele sempre apanha quando leva bilhete e ele diz que depende da bagunça.

Malu dá outra bronca em Jordan.

Alan me chama, logo depois da bronca, para falar mal de Jordan: "Ainda responde à professora, você viu?" Não sei o que realmente aconteceu nessa última bronca, nem sei se Jordan disse algo. Eu estava entretida conversando com lgor e não consegui prestar bem atenção. Só sei que Igor ficou feliz com a bronca.

16:00h 0 tempo na sala de aula foi passando e não sei por qual razão as crianças não saíram para o recreio. Parece que, realmente, algo mudou na rotina da escola, pois nem sequer os sinais dos recreios anteriores tocaram. Pelo barulho, não parecia que os alunos estivessem no pátio. Quando me dou conta disso, resolvo me aproximar de Malu antes que ela comece a fazer a correção das contas na lousa. Estou muito cansada e já mal consigo prestar atenção àquilo que ocorre. 
Levanto-me e, com a desculpa, de entregar as provas de Uelinton me aproximo dela. Entrego as provas, a respeito das quais Uelinton havia dito "são da professora", agradeço por elas. E ela diz que deixou com Uelinton, pois ele contou que iria me encontrar e pediu. Pergunto como os alunos foram nas provas e ela faz uma cara ruim e diz "não foram muito bem, não". A princípio Malu começa a criticar a prova elaborada por ela própria. Pergunta se eu vi a prova e digo, sinceramente, que apenas xeroquei junto com uma série de outras coisas. Mal tive a oportunidade de vê-la. Malu diz que não queria ter feito daquela forma, diz que queria ter mimeografado. Estranho o fato de Malu dizer isso e pergunto a ela: "Mas você não mimeografou?". Ela diz que sim, que tinha se enganado. Na verdade, queria fazer xerocado, mas não havia material suficiente, "os pais não mandam" e por isso precisou fazer daquela forma. Diz que para mandar dinheiro para o material ninguém tem, mas para tirar a foto todos arrumam. Eu já tinha ouvido falar dessa foto algumas vezes, e perguntei que tipo de foto era. Ela conta que é uma foto de toda a turma para eles guardarem como recordação.

Volta a falar da prova e diz que há várias falhas no texto, devido ao mimeógrafo, isto é, há alguns trechos quase apagados que dificultam a compreensão. Mas, conta que tomou o cuidado de ler toda a prova com eles e de anotar na lousa tudo, para que eles completassem. Conta que nem todos quiseram fazer as correções na prova. Por ela, fazia uma prova escrita a mão, por eles mesmo, achava que teria sido melhor. Eles copiavam tudo. Conta que não queria dar prova, foram os próprios alunos que pediram. Diz saber muito bem quem sabe e quem não sabe na sala de aula. "Então eu não sei quem sabe e quem não sabe fazer conta?”. Mas acabou fazendo a prova. Diz que a sua letra está muito pequena, havia poucas folhas e ela teve que fazer tudo bem apertado. Novamente, Malu fala mal de si própria e de seu trabalho, como que assumindo a autocrítica, antes que eu tenha a oportunidade de criticar ou ver os defeitos de seu trabalho. É interessante o quanto ela centra suas críticas nos aspectos mais formais de seu trabalho. Nisso, parece reproduzir algo tão comum na 
cultura escolar: a valorização excessiva da apresentação e da forma em detrimento do conteúdo.

A sala de aula está uma bagunça, como quando eu ainda estava sentada. Muito barulho, diversos alunos em pé. Enquanto conversávamos, Igor anotava os nomes na lousa e Malu nem sequer olhava para aquilo que ocorria. Apenas conversava comigo. Interrompemos a conversa apenas em duas situações. A primeira foi quando Heitor veio pedir ajuda para fazer uma das contas. Nem sei bem o que ele perguntou, pois ele falou baixinho, a sala bastante barulhenta. Malu deu alguma orientação que me pareceu lembrar-lhe a tabuada. Parece ter feito um pedacinho da conta junto com ele. Outra situação que provocou a interrupção foi quando dois alunos, Sandro e Ronaldo, apareceram na porta da sala de aula com a cabeça molhada, água escorrendo na roupa. Estavam todos molhados. Aparecem na porta da sala de aula rindo e os outros alunos chamaram a atenção de Malu para o fato. Malu vai até a porta. Dá uma severa bronca nos alunos e diz que eles não vão entrar daquela forma. Vão ficar lá fora até secarem. Empurra alguns alunos que estavam na porta, dizendo para que eles não se intrometam. Alan tenta fazer algum comentário e Malu diz para ele parar de ser fofoqueiro.

Malu volta à nossa conversa, após a bronca. Diz algo sobre as dificuldades de ser professor conta que está estressada e pergunta "como é que eu vou corrigir prova aqui?” Diz que não tem jeito.

Conta que amanhã não virá. Pergunto se não haverá aula e ela diz que não é isso, ela é que vai faltar mesmo, "pra resolver umas coisas". Diz que vai aproveitar para corrigir provas. Em casa é melhor, mais tranqüilo. Fala dos riscos de corrigir na sala de aula e fazer alguma correção errada, [“vem um pai em cima de mim”]. Diz que vai corrigir em casa. Corrige um pouco, pára quando cansa. Faz isso enquanto assiste a novela. Malu conta sorridente que não virá amanhã. Novamente, fica evidente o quanto ela está sobrecarregada. Afinal, até mesmo no dia em que vai faltar, se dedicará a algo que diz respeito à escola: vai corrigir as provas. 
Malu fala de seu medo de castigar um aluno e ser punida pelos pais. Pergunta se eu estou sabendo do caso de Nova Odessa. (Um caso que, depois vim a saber, está sendo bastante divulgado e explorado pela imprensa local. Parece ser uma situação bastante controversa. Um aluno teria sido castigado pela professora por não ter entregue um livro da biblioteca no dia. 0 castigo era ficar atrás da porta. A mãe teria encontrado o filho quatro horas depois do término das aulas em estado de choque. A escola diz que isso não aconteceu, que houve uma reunião com diversas famílias após as aulas e que o menino foi visto, tendo chegado a ajudar algumas pessoas a conseguir cadeiras. Não entendi bem, mas soube que há uma busca, agora, pelo caderno do aluno. A professora diz que vistou todos os cadernos e também o dele. 0 caderno serviria como prova de que o aluno realmente estava na aula.) Digo que não, e ela conta sobre um aluno que tinha ficado atrás da porta, por um castigo da professora. Todos os alunos e a professora teriam ido embora e o aluno teria ficado atrás da porta. Mais tarde, a mãe deu conta da sua falta e foram encontrá-lo atrás da porta. Malu fala de suas dúvidas a respeito da possibilidade de que isto tenha acontecido. Imagina que não seja possível todos os alunos saírem e ele não perceber, mantendo-se atrás da porta. Diz que: ['nenhum aluno é tão obediente, assim']. Passa a contar um caso ocorrido na outra escola em que dá aula. Diz que um grupo de pais estava na frente da escola para linchar a professora. A situação que gerou tal reação foi o fato de uma mãe de aluno ter visto a professora 'batendo' em um outro aluno. Essa mãe organizou um grupo de outras mães e elas estavam protestando contra o que teria ocorrido. Segundo Malu, a professora teria apenas segurado no braço do menino (ela demonstra no meu braço como teria sido, pegando com força e sacudindo; confesso que não foi um chacoalhão agradável, ainda mais que fui pega de surpresa, mas também não diria que ela me 'bateu'). 0 próprio menino diz que a professora não the bateu, a mãe do menino também estaria contrária à movimentação das demais mães.

Malu diz que é preciso tomar cuidado com os pais, especialmente esses que vivem na escola (fala de modo extremamente pejorativo dessas mães). 
Faz comentários sobre as dificuldades para lidar com os alunos. Comenta o episódio de hoje com Jordan. Diz que pegou as figurinhas dele, pois senão eles não param. Conta que vai devolver, afinal 'custa dinheiro'. Depois, conta que não restringe tanto assim. Até permite que eles joguem, mas só quando já acabaram as lições ou [“"na última meia hora de aula, quando já não dá para fazer nada, mesmo"].

Faço menção de ir embora, já havia chamado Natali (que enquanto eu conversava com a professora, conversou com Jordan, que estava arrasado em sua carteira; pedi a ela, também, que marcasse nosso encontro com ele na semana que vem). Mas, Malu me segura mudando de assunto. Agora, Natali nos acompanha. Ela passa a falar da prova de Uelinton. Minha sensação foi de que ela realmente queria me segurar lá. Mudou de assunto para algo que ela sabe ser do meu interesse. Esta é uma relação repleta de ambigüidades. Por um lado, sou alguém que exerce alguma vigilância sobre o trabalho de Malu, que the suscita a necessidade de dar explicações e de assumir suas falhas. Por outro lado, em alguns momentos, ela parece gostar da minha presença. Quais seriam as razões para isso? Malu teria em mim uma possibilidade de escapar um pouco do barulho e das exigências da sala de aula? Ou, seria eu uma pessoa com quem ela pode dividir, desabafar as dificuldades que encontra em seu trabalho?

Malu começa, então, a comentar a prova. Mostra a prova de Matemática de Uelinton. Diz que ele foi bem, errou apenas uma coisinha. Depois mostra a redação, pergunta se eu já tinha lido. Digo que não. Lemos juntas. Mas, antes, Malu diz que Uelinton tanto escreve muito bem, como muito mal. Começamos a ler, e o texto, apesar de ter uma série de erros de ortografia, mostra uma sensibilidade poética que me surpreende. Ele faz referência a um desejo de voltar para a Bahia, de conhecer sua 'terra natal', como ele nos havia dito um pouco antes, ao voltarmos das entrevistas. Uma das minhas perguntas de pesquisa tem sido o quanto o conteúdo dos textos relaciona-se com aquilo que os alunos realmente vivem e querem. Aqui, neste texto de Uelinton, aparece uma expressão bastante pessoal de desejos. Interessante haver a possibilidade deste tipo de expressão num texto feito em uma prova. Malu parece 
gostar, também, do resultado. Diz que ele usou muitos elementos do texto que ela havia dado na prova. Malu lê uma parte do texto em que há imagens usadas por Uelinton em seu texto: o zíper da mala que quebra, a necessidade de amarrá-la. Malu volta ao texto de Uelinton, e lê a frase final, na qual ele fala que gostaria que sua mãe voltasse a ver. Então, Malu me conta uma história que já me era familiar: Uelinton é filho de pai e mãe cegos. Eu já tinha ouvido falar que havia uma família assim na região. Uma vez tinha visto uma mulher cega entrar na sala de aula, mas não imaginava que Uelinton fizesse parte dessa família. Malu conta que ele é quem faz uma série de coisas na casa. É ele quem acompanha a mãe quando ela tem que sair. Conta que agora a mãe se separou do pai e mora com outra pessoa, o novo namorado também é cego.

16:10h Um aluno chama Malu e nos interrompe. Aproveito a pausa para me despedir dela, dizer que volto na semana que vem. Quando ela vai se despedir de Natali, a chama de Silvia, e se desculpa pelo engano.

Me despeço de Ralph, que está praticamente no meio do caminho. Ainda está sentado perto de Jennifer. Ele diz que tem uma coisa para mim, vai até sua carteira e pega um caderno. Diz que é para mim. Pergunto se não vai mais usar e ele diz que não. Parece que desta vez não houve uma censura prévia. Ou a censura foi tão premeditada que eu não vi ser realizada. Preciso olhar com calma o material que ele me deu. 


\section{ANEXO C \\ ENTREVISTA COM PROFESSORA}

Transcrição da primeira etapa da entrevista com Silvia

P - Pesquisadora

S - Silvia

P: Aquilo que você estava falando, com certeza...

S: Eu acho que não é no caderno só que está a aprendizagem. Porque eu tenho caderno, porque a minha relação com o caderno nem sempre é aquela relação de aprendizagem. Porque às vezes eu não registro, assim: “ai, hoje a aula foi legal, tal.”. E a minha vida com o caderno, chegou uma época quando eu fiz faculdade, que o caderno não tinha mais significado, porque eu aprendia muito mais ouvindo e discutindo do que anotando. Então, eu cobro o caderno deles, que eles tenham organização. Mas que eles saibam pegar o caderno e ver o que que aconteceu e explicar o que é aquilo. Eu acho que tem que ter sentido aquilo que eles anotam, que eles aprendem. Então quando tem as atividades, assim, de corrigir texto, né? Aí, eles ficam assim: “É pra copiar? É pra copiar”. "Olha, quem está a fim de só registrar no caderno e não saber o que que é copia, quem está a fim de participar..." Porque eu acho que a sala de aula é muito rica. Tanto que uma vez eu fui em uma palestra e o professor falou: "Por mais organizado que o professor seja, por mais certinho que ele tente organizar, em uma sala de aula acontecem coisas que ele não dá conta." Porque é briga que você separa, às vezes você não está esperando e eles fazem. Você pensa de um jeito, eles fazem de outro. Teve uma atividade que eu dei no quadro mágico, tanto nessa sala, quanto na outra. Era pra fazer uma operação inversa. Quando eu trouxe, tanto pra eles quanto pra outra turma, não foi na operação inversa que eles fizeram. Eles fizeram várias maneiras e nenhuma criança fez do jeito que eu tinha pensado.

\section{$\mathrm{P}: \mathrm{O}$ que que é o quadro mágico?}

S: Tinha que dar uma soma de 185. Aí, tinha uns números. Vamos supor, tinha $25 \ldots$ O valor que dava 185. Tinha dois números, eu somaria, tiraria depois e via o que falta. Eles foram por aproximação. Teve criança que foi de um em um contando. Outros: "Ah, na unidade tem que dar cinco. Então, eu só vou usar número que dê cinco na soma". E não foram nem uma vez como eu tinha pensado! A atividade de sexta-feira, que era do dobro. Quando eu vi, na hora, eu pensei em somar um número que dava 9. E eles não conseguiram fazer. Mas quando um fala e o outro fala... Porque a aprendizagem vem dessa interação. Então, quando a gente trabalhou as regiões, né? E quando eu vi... Peguei um livro, estava trabalhando no assunto, que eu percebi que eles não tinham conhecimento. Que país era esse, que espaço que representava o mapa. E eu trouxe para a sala. Eu sei que hoje, se eu for perguntar cada estado, eles não vão saber, podem errar. Mas, eu percebo, assim, que foi significativo aquilo. Que fez o mapa...E tudo isso que aprendeu não está no papel. Então, assim, a relação com o caderno, eu não sei se a criança consegue ter essa importância. Porque eles jogam fora o caderno... Eu já perguntei. "Ah, não serve pra nada eu jogo fora!" Eles não têm essa relação de registro, de guardar, de saber o que que é. Troca de caderno, não tem organização. O Ralph, vira e mexe, está com um caderno novo! Que ele fala que o 
caderno dele está relaxado, aí ele troca. Mas, aí, ele não traz o caderno. Às vezes, você vai usar, e não tem...

\section{P: Você sabe o que ele faz com o caderno?}

S: Eu não sei o que ele faz! Mas ele, vira e mexe, troca e fala assim: “Ah, meu caderno estava muito bagunçado!". Porque ele fica atrasado, né? Aí, ele pula folha, só que depois ele não põe em ordem. Aí, quando eu falo: “Ah, vou olhar o caderno". Aí, eu falo: “Ih, Ralph, seu caderno está desorganizado". Daí, ele fala: "Não, eu vou arrumar!” Daí, ele aparece com um caderno novo! Porque ele quer ter aquele caderno caprichado. Mas, como ele perde... Então, eles não têm. Porque, assim, caderno pra eles não é aquele material de estudo. Nem pra prova... Quando eu ia pra escola, que eu não tinha livro, era caderno que eu usava. Mas, eles não têm essa coisa de pegar o caderno, estudar. Tanto que às vezes eu até faço assim: deixo passar dois dias, daí a gente volta pra olhar no caderno, procura data. Eu peço que eles tenham um caderno organizado, mas eu não sei se a aprendizagem vem... É como você falou, nem só desse caderno, desse registro. Vem de toda a construção que é feita na sala, mesmo! Tipo correção de texto, o que vai pro caderno, que é o registro do texto corrigido, quando você olha aquele texto... Ontem, eu dei. Então, está lá colado o texto que era pra corrigir. A idéia, né? Não tinha ortografia. E o texto corrigido em baixo. Então, você olha e não tem aquele contexto... Aí, diz: é uma copia de um texto corrigido. Mas a gente discutiu, viu que estava faltando idéia. Acho que aprendizagem vem disso mesmo, de troca mesmo.

P: Foi interessantíssimo quando eu acompanhei aquele dia que vocês estavam fazendo o texto juntos...

S: Hum hum. (riso) E aí a gente sempre, eu faço correção de texto. Ou, assim, pra registrar um conteúdo, ou é pra corrigir mesmo. Então, a ortografia. Porque, às vezes, eles escrevem e como têm bastante dificuldade, eles não percebem as sílabas complexas. Aí eles escrevem.... Ontem eu fiz uma frase: "O meio ambiente ..." Eles escrevem grudado, põem o ' $n$ '. Quando coloca o ' $n$ ', que já é erro de ortografia, mas você deixa, que pelo menos percebeu o som da letra. Aí, eu vou lá e leio com eles. Aí, eles vão falando o que está faltando. Eles começam a perceber, também, que tem que ter uma clareza na hora de registrar alguma coisa, que eu penso... Tanto que ontem, o texto, eles falaram que o texto estava maravilhoso. Aí, eu falei :"Gente, olha o segundo parágrafo, vamos ler". Li várias vezes. "Ah, não está dando pra entender o segundo parágrafo do texto". Estava bem confuso. Eu falei: "Oh, sabe o que deve ter acontecido? Porque a mão da gente não acompanha o pensamento. Aí, faltou uma palavra, perdeu todo o sentido". Aí, a pessoa que tinha escrito, ela olhava pra mim. Aí, eu falei: "Olha, não estou falando que o texto...Não quero..."

\section{P: Era o texto de uma pessoa da sala?}

\section{S: De uma pessoa!}

\section{(pausa - pessoa entra na sala para falar com Silvia)}

S: Aí, era o texto da classe, de uma pessoa da classe. Mas, eu não ponho o nome. Se a pessoa quiser se identificar... Na outra sala, no final, eles acabaram se identificando. Nessa sala, ainda ninguém se habilitou a se identificar.

P: É, eu já acompanhei. 
S: Eles não se identificam! Aí: "Não é que eu estou falando que esse texto está ruim. É que escrever é difícil mesmo, a gente escreve uma vez. Só que tem que estar claro, primeiro, pra gente, que tem que se preocupar com o leitor"

(pausa - a diretora da escola interrompe a entrevista para falar de um aluno que tem vindo à escola sem uniforme)

S: A gente estava falando do texto lá, né?

P: É!

S: Aí, é o texto de uma pessoa. Eu deixo claro, assim, que eu não estou pegando o pior texto. É o texto melhor para se analisar. Às vezes é de ortografia, ou é parágrafo, que está faltando parágrafo, pontuação. E ontem, era a idéia, mesmo, que estava bem confusa. Faltava uma palavra. Aí, eu explico o que é aquilo. Sei que a pessoa não gosta muito, não; que ela fica meio constrangida. Mas pra eu corrigir aluno por aluno... E no caderninho, às vezes, eles não fazem de novo. Eles querem ver só se tem bilhete bom. Assim, quando está 'parabéns', 'que legal', 'você está melhorando', aí eles ficam felizes! Aí quando está assim 'reescreva seu texto', aí, às vezes, não retorna. Mas, lá no caderno, quando eu fiz, é mais um registro pra mim do que acho que pra eles. Porque você vê o desenvolvimento deles no primeiro texto, do último texto. Teve criança que foi assim: "Você vai ter que fazer porque está faltando parágrafo. Aqui podia ser um parágrafo, aqui poderia ser outro.” . Teve dois que pediram pra irmã poder ajudar. $\mathrm{E}$, hoje, eles já sabem que têm que usar parágrafo. Eles já estão usando parágrafo. Aí você vê o rendimento assim da sala.

P: E isso você leva pra casa?

S: Levo pra casa, leio.

P: Aí, você leva todos?

S: É, eu vou corrigindo aos poucos esse caderninho. Aí, quando eu consigo corrigir a maioria, aí eu devolvo pra eles...

P: É um caderno à parte?

S: Isso! Você quer dar uma olhada? Está no meu armário!

P: Se você quiser mostrar.

S: Acho que tem um no meu armário. Porque o ano passado, eu dava bastante coisa de português, só que estava em folha. E eu achei que na folha você não consegue ver o que acontece com a criança. Vai a folha, eu dava pra eles corrigirem, mas às vezes não devolvia. $E$, aí, no caderno eles estão sempre em contato. Quando devolve o caderno, eles ficam procurando bilhete que eu escrevo.

P: Você acha que pra eles fica...

S: Pra mim fica mais fácil de ver. E, pra eles, assim, não é só porque eles escrevem errado que... (Silvia folheia um caderno). Essa foi, acho, que a primeira atividade você acompanhou.

P: Foi! 
S: Que é do alfabeto, e eles tinham que fazer outro! Aí teve isso, tal... Aí, eu já não coloquei muito bilhete. (pausa)

P: Esse aqui é de quem?

S: Acho que é do Leonardo! Da Tainá, aí, ela já não tem tanta dificuldade, então ela já usa parágrafo, já.

P: Aí você sempre faz algum recadinho?

S: Sempre faço algum recado pra eles! Oh, o da Bruna eu corrijo, tem palavras assim, olha: 'Parabéns, cada dia seus textos vão ficando melhores'. Aí, tem os outros...

P: E eles lêem esses...

S: Lêem! A hora que devolve o caderno, a primeira coisa que eles vão olhar é pra ver se está escrito parabéns! Aí, quando tem aquele parabéns, você vê aquele rostinho de satisfação, assim.

P: E quando tem algum erro de escrita, eles atendem, eles fazem?

S: Olha, o Heitor refez. Mas, eu vou ter que sentar com ele. Ele usou a idéia do texto. Se você ler, você percebe uma seqüência. Aí, ele não usou o parágrafo. Aí, eu marquei o ponto final e o parágrafo. Mas, ele não conseguiu fazer de novo. Daí, eu falei: "Henrique, depois eu sento e faço com você". Tem criança que não atende não!

P: Mas, você acha que ele não entendeu o que você tinha pedido?

S: Eu acho que ele não conseguiu entender aqui, olha. Eu marquei aqui, oh, segundo parágrafo. E eles não têm o hábito de usar letra maiúscula, de dar espaço de parágrafo. Eles vieram para a quarta série sem esse conhecimento. Não dão importância, assim, não têm essa preocupação de escrever certo. Aí, eu escrevi um bilhete. Eu chamei ele e falei: "Olha, você tem que fazer de novo, está marcado, escrevi”. Aí, ele fez. Mas, acho que ele não conseguiu entender o que era pra estar sendo feito, pra ler de novo, tal. Oh, do Cristiano eu não consigo ler a letra dele.

P: Que é pequenininha, né?

S: Oh, era assim, e eu não conseguia ler. Aí, ele diminuiu. Mas, aí, eu estava fazendo tipo um caderno de caligrafia, mas eu não estava entendendo o que ele escrevia.

P: É, outro dia eu estava vendo e a letra dele é pequenininha de tudo. Olha que clarinho, né?

S: Oh, ele diminuiu assim. Essa aqui eu consegui ler...

P: É, ele deu uma mudadinha, né?

S: Isso, ele está se esforçando. Eu falo: “Olha, faz um pouquinho maior”.

P: Aí você colocou: 'Consegui ler o texto, mas ainda você tem que tornar sua letra legível' (risos de Silvia) 
S: E texto que eu dou, sempre é de assunto que está relacionado. A gente trabalha um assunto...

P: São os temas que vocês têm trabalhado?

S: Isso!

P: Tá. Tem dicas assim: “Não precisa pular linha depois do parágrafo”.

S: Isso, isso. Porque quando eu fui falando de parágrafo, não sei se foi a minha maneira de falar, o Cleber, o Alan, o outro Alan, quando eles iam fazer parágrafo, eles estavam marcando primeiro parágrafo, segundo parágrafo. Porque eu fico: “Oh, primeiro parágrafo faz assim, olha". Eles marcam com um travessão.

P: E travessão, mas não é travessão de diálogo?

S: Não, não é de diálogo. É travessão para marcar o parágrafo.

P: Entendi, entendi. Mas, você tinha usado isso na lousa?

S: Não usei, mas eu acho que eles sentiram a necessidade de marcar que eles estavam usando parágrafo.

P: Tá. Esse é do Jean... Como se fosse um jeito de te contar: 'olha, eu fiz'.

S: Isso, isso! Olha: "Parabéns pelo esforço, já melhorou bastante”. Aqui. oh, aqui ele reescreveu, o lgor. 0 Igor resiste a tudo o que é de leitura e escrita.

P: 'Você vai reescrever seu texto deixando espaço para os parágrafos. E não se esqueça de corrigir as palavras grifadas.'

S: Ah, mas, tudo o que é de leitura escrita, o lgor...

P: Ele reescreve? Não?

S: Não, ele nem... Quando é o Ralph, também, ele não faz. Oh, o Alan que gracinha. Não usava parágrafo. Esse aqui foi um texto que eu dei e que a maioria teve dificuldade. Aqui, ele começou a usar em um, aqui ele já esqueceu do outro. Ele apagou os travessões que ele marcava, ele apagou. Aí, aqui ele já usou parágrafo sem marcar. Aí, ele já usa parágrafo. Aí, às vezes, ele usa linha pra marcar, olha. Já escreve um texto que tem coesão e usa pontuação e parágrafo. Tudo!

P: Esse pelo jeito ficou bom. Você grifou pouquinha coisa e deu parabéns. (risos de Silvia) Isso que você estava falando de tentar criar com eles o hábito de retomar. Você acha que acontece com esses textos aqui?

S: Eu sinto com o aluno que... Acho que até quando eu era professora, assim, que quando o professor pede pra gente fazer de novo, e a gente é criança, na cabeça, é porque a gente está fazendo muito errado. Não que é pra você crescer. Porque quando eu fui fazer faculdade, você escrever um texto é muito difícil. Você ler um texto, você tem que escrever... Tinha uma professora que quando ela devolvia, ela colocava um ponto de interrogação, não tinha ligação com os outros parágrafos. E lá com ela que eu fui entender que, quando você 
escreve de novo, e você lê, você melhora. Eu sinto neles, assim, vai pra lousa, dá aquela tremedeira. Eu falo pra eles: “Pode vir, eu não vou morder não!”

P: O Ralph adora!!! (Risos de ambas)

S: Chora, implora.

P: Hoje eu estava até anotando aqui. Ele falou que 'ele era sortudo'.

S: E o Clóvis não queria ir. Ele falou: “Ah, eu não vou!" E chega na lousa até sabe, fica com medo. Em prova também é uma catástrofe porque eles ficam nervosos. Então eu sinto que, hoje, quando eles são crianças, o retomar deles é no sentido de cobrança. Porque você está errando, não é no sentido de crescimento de estar melhorando, aprendendo mais! $E$ eu só fui aprender isso, quando eu fiz faculdade, com essa professora. E isso foi uma coisa que eu cobrei de mim. Que era um trabalho... Eu não tinha aprendido direito a fazer as técnicas de um texto cientifico, assim, que tinha as normas, tal. E ela chegou e cobrou de todo mundo. Aí, eu fiquei um tempão, né? E a minha, assim, eu lia o meu texto e lia o livro e falava assim, como eu era modesta também, né? Olhava e falava: "Nossa, olha que porcaria. E olha o da autora! ". (riso) E quando ela sorteou pra ler, eu fui sorteada aquele dia. E eu lembro até hoje que me marcou muito aquilo. E eu falei: "Pode jogar os tomate agora", porque pra mim aquilo estava muito horrível. E não estava muito horrível. Porque eu sou muito assim, se alguém fala: "você não consegue", aí, eu provo com aquilo e mais um pouco. Aí, ela falou: "Não, só faltou a parte da avaliação". Porque o assunto era sobre avaliação e planejamento para aluno com deficiência. Aí, eu fui e fiz esse texto. Daí, no outro, eu estudava de sábado à tarde, e fui sábado de manhã. Aí, eu fui e escrevi e ela elogiou de novo. Aí, eu tomei gosto por escrever. Tanto que hoje eu não tenho medo de escrever. Eu já fiz trabalhos para outras pessoas e eu não tenho. Eu tenho habilidade de estar escrevendo, de estar falando sobre um assunto, tal. Mas isso veio depois. Hoje, a criança sente que, quando o professor se aproxima, é pra cobrar dele. Então você está fazendo errado. Tem um certo endeusamento assim do professor. Eu sinto assim. Por exemplo, quando o Ralph falou: "Ai, Jéssica você..."

\section{P: “Ainda quer duvidar da professora?”}

S: Isso, isso. Daí, eu falei assim: "Não, eu erro, porque às vezes eu vou fazer conta, está barulho e eu me perco todinha" Eles falam assim: "Não, está errado" Aí, eu falo: "Calma!" Aí, eu apago e faço tudo de novo. E tem o endeusamento do professor, que sabe tudo, que nunca erra, que não esquece. E eu falo: "Oh, eu não sei tudo". Mas por mais que a gente fale, eles acham que o professor sabe tudo! Outro dia, eu vi um menino falando assim: "Você queria ser a Dona?". Daí, outro falou assim: “Ah, eu não, porque ela é mulher!". "Ah, eu queria, porque ela já sabe tanta coisa que a gente não sabe!" (riso) E tem esse endeusamento. Mas, a escola, assim, ela é um lugar muito rico, que ela vai além da leitura

e da escrita. O relacionamento, coisas que você aprende... E o que marca, na verdade, também é a amizade, né? Você não lembra da escola, daquilo que você aprende, aquela coisa, você lembra do amigo que você fez, da brincadeira que você tinha no corredor. Não do aprendizado. Então, da faculdade, quando eu lembro, eu lembro das minhas amigas, tem algumas professoras que me marcaram. No colegial, minha turma de terceiro ano foi ótima. Mas, o aprendizado, você vai guardando aquilo na memória. Você tem muito de se perguntar: por que eu estou ensinando isso?; por que eu estou aprendendo isso? Eu lembro que eu fazia trigonometria, e eu ficava perguntando: onde eu vou usar isso? E nunca usei na verdade! Então, eu acho que ela é rica por esse lado, a escola. E, por outro lado, ela também quer, né, fazer isso! Porque vêm coisas pra gente, professores que você não aceita, tem que fazer. Falta união na classe, aí você não vai dar a cara a tapa sozinha. Então, em 
reunião, ontem mesmo, veio avaliação que as meninas têm que fazer de desenho. Eu não tenho habilitação pra pré-escola, não era comigo, mas aquele dia começou, né? Aí, eu falei que discordava, que não era por aí...

\section{P: Que era uma avaliação...}

S: De desenho, que elas têm que fazer. Que eu acho que é assim. Hoje, o pessoal analisa muito a escrita da criança, então são os níveis. Então, todo mês, você entrega como é que está a sua classe em relação aos níveis de escrita. E aí, agora, eles começaram desde o pré. Então, eles vão começar a fazer essa avaliação, agora, dos desenhos de uma escrita. Então, espera-se que as crianças sejam pré-silábicas, que elas não têm noção que escreve com... Às vezes, tem algumas que já sabem que escrevem com letras, mas que não conseguem parar para pensar. Então, qualquer letra que ela usar ela vai escrever. Outras que ainda acham que desenhando é que se escreve, que a gente chama de pré-silábico. Aí, depois vai ter outra, e no final tem outra. Aí, a gente falou que chega na primeira série, tantos pré-silábicos vão para a primeira. Quantos no final do ano conseguiram se alfabetizar e quantos não se alfabetizaram? Ao invés de buscar o porquê que não estava aprendendo, vamos colocar em gráfico. Aí, parece que o professor não fez. Ninguém senta, assim, e fala: "Olha, essa sala está com problema. O que que a gente vai fazer?". Então, esses gráficos eu fico assim: você faz, faz, faz, e aí, chega na quarta-série você recebe um monte de aluno com muita dificuldade. Tanto que aquela vez que eu fiquei com alergia, eu acho que foi aqui que eu... Por mais que o ano passado eu já tinha lidado com uma situação parecida na segunda- série, que eu estou dando aula de manhã, chega em uma segunda-série, tem 34 crianças, 17 sabe, 17 não sabe. É muita criança. E não é problema de dificuldade de aprendizagem. Alguma coisa se perdeu no meio do caminho. Chega na quarta-série aluno com muita dificuldade de leitura e escrita. E aí, você vai dando dados que, ao invés de ajudar, não serve pra nada, assim, só pra por lá na secretaria. E o pessoal tem muito medo de falar as coisas, sabe? Eu sempre estou falando, assim, não tenho medo de falar, de questionar, de estar investigando. Então, você se perde muito. Isso é o que eu não gosto e que eu não gostei na educação regular. Cumprir tarefa. Você vai fazer um cartaz, vai lá e faz. Uma quer fazer melhor que a outra, mas o aluno não pôs a mão e aquilo não tem sentido nenhum. E aí, cumpre tarefa. Isso eu não gostei de trabalhar na educação regular. Então a educação especial, como o pessoal tem menos conhecimento, então eles te dão um valor maior, assim. Você tem uma relação diferente, e na educação regular não tem isso. Parece que você nunca sabe nada. Aí, não tem uma pessoa que consiga te orientar, sabe? É bem difícil. Porque eu prestei mestrado lá em São Carlos, né? Passei e eu parei no meio do caminho ( Silvia ri envergonhada).

\section{P: Na USP de lá?}

\section{S: Não, na Federal lá!}

$$
\text { P: Ah, na Federal... }
$$

S: Isso! Só que, quando eu passei, eu passei, assim, eu fiquei com aquela vaga lá, que se sobrasse alguém, me chamaria. Aí, uma pessoa desistiu e eu fui chamada. Só que, na minha cabeça, eu não estava no nível das outras pessoas, e eu estava fazendo um trabalho diferente na APAE. E quando na APAE, eu estava trabalhando com inclusão dos alunos. E era só eu sozinha, assim. Tinha uma pessoa que trabalhava, mas eu não tinha pra quem recorrer, a angústia vinha tudo pra cima de mim, eu não soube lidar com a situação. Eu sempre gostei muito de estudar, eu não conseguia fazer os trabalhos e sempre achava que estava inferiorizada, sabe? Porque na APAE eu ouvia o tempo todo: "Isso aqui não está certo, isso aqui não está certo", da pessoa que foi trabalhar do meu lado. Aí, eu não soube lidar. Aí, eu parei no meio do caminho. Aí, eu não terminei nem o primeiro semestre! 


\section{P: E era um mestrado ligado à educação especial?}

S: À educação especial. Era na época que estava estourando a inclusão dos alunos. Aí, eu falei: "Não, eu vou estudar sobre isso. Porque aqui na APAE a gente não dá conta, e vai colocar as crianças na rede?". E eu lembro que, assim, foi legal o processo. Porque quando eu fui, quando eu fiz faculdade, o professor falou o que era inclusão, o que era integração, a síndrome do Avestruz. E eu tirava nota, mas tinha construído o conhecimento, conceito. Quando eu li coisas que já tinha lido na faculdade, foi um bloqueio, assim. Sabe quando você não consegue ter clareza do que é direito? Aí, eu fiz o projeto. Eu fiz faculdade, fiquei um ano, né? Final do ano, fiz um projeto. Pedi pra essa professora dar um lida. Eu nunca tinha feito pesquisa. Aí, ela falou: “Ai, eu acho que está bom”.

\section{P: Foi essa professora que você tinha contado?}

S: É, é. Aí, eu voltei, ela falou assim: "Eu acho que está bom. Mas se você não passar, você não desiste! Porque não é assim que você vai na primeira e passa!”. Aí, eu fiz. Aí, eu liguei, né? Falaram que eu tinha ficado pra espera. Falaram que, se eu quisesse, eu poderia me matricular como especial. Aí, eu fui e fiz a matrícula. Quando eu ia começar como especial, comecei como regular. Aí, eu já estava ansiosa tudo, eu não soube lidar com a situação. Aí, eu parei. Eu vou voltar ainda, né? Só que agora, como eu saí da educação especial e vim para a educação regular... Porque, aí, eu fiz um curso de pós, e fiz a monografia da inclusão, só. Eu sei que foi uma pesquisa bem restrita, tal. E como eu trabalhei como itinerante, eu aprendi outras coisas. Aí, eu queria estudar, assim, a função, como que o professor de Educação Especial é visto na escola regular. Mas, agora, como eu estou na educação regular, estou com um ponto de interrogação na minha cabeça. Porque faz dois anos, três, né? Que eu não lido com educação Especial. Então, eu não consigo sentar e escrever. Não estou tendo clara a idéia. Mas, eu quero fazer mestrado. Como eu larguei no meio, eu tenho que terminar!

\section{P: E tem como voltar?}

S: Não, esse eu já perdi! Eu tenho que prestar de novo, só que lá em São Carlos você tem que ter inglês que está sendo eliminatório. Aí, na Unicamp eu pensei em estar prestando. Aí, eu sei que, assim, seria interessante que eu fosse como ouvinte, pra depois chegar lá, né? Só que esse ano, eu não vou conseguir estudar para prova e ter clareza do projeto. Porque eu lembro que, na entrevista, você tem que ter muita clareza do que você quer. Que lá em São Carlos eles perguntaram o que eu queria, tal; eu tinha mais clareza, e hoje eu não tenho. Então, por mais que eu escreva, eu não vou ter. Eu quero fazer mestrado. Eu acho que, assim, eu não quero ser diretora, não quero ser coordenadora, não quero ser vice. Eu tenho essa vontade de estudar, de ter conhecimento. Não que eu saia da sala de aula, talvez nem pra tanto, mas pra ter conhecimento maior. Que eu faço curso, e às vezes eu consigo trazer para a sala. E, às vezes, eu fico assim: nossa falta tanta coisa e eu não, não... Lembra que eu falei: ai, eu acho que a sala não rende? Eu olho, chegou o meio do ano e parece que não foi. Aí, tem dia que eu saio coma sensação que eles aprenderam, tem dia que eu saio com a sensação que não, eles não aprenderam. Então, na educação regular, ela é mais angustiante que a educação especial, eu acho! Porque a educação especial você está ali. Quando ele está na educação regular, você luta pra ele ficar, e você tenta convencer o professor que a sala de aula é muito mais do que ler, escrever, aprender os estados, que aprender matemática. É muito mais do que isso. Quando você vem pra sala regular, você inverte a situação. Aí, você recebe um aluno e fala: “Como é que eu vou lidar com isso?". Que tem a Lauriane que tem dificuldade, às vezes eu não consigo. O Jordan, o Fabrício. E quando elas falavam alguma coisa, eu falava: “Não, não é bem verdade". Às vezes, elas estão com receio de receber. E não é. Então, eu estou em um mundo complexo assim, sabe? Que eu não estou entendendo 
direito pra eu poder fazer outra coisa. Mas eu gosto do que eu faço, eu tenho amor, não me arrependo em momento algum assim...

\section{P: E como tem sido lidar com a Lauriane, com o Jordan?}

S: Olha, com a Lauriane eu acho mais difícil do que com o Jordan. Porque o Jordan, toda hora, ou ele pergunta, ou ele atormenta, né? Então, dá para ajudar porque ele vem buscar. E o Fernando também. Agora, a Lauriane não! Se ela senta, ela entra muda e sai calada. Se você vai até ela, você explica; mas, eu precisaria de mais material concreto pra trabalhar com ela. Em um texto assim, eu tinha que sentar com ela, trabalhar com ela, fazer por partes. Porque ela tem uma dificuldade maior. E ele, o Jordan, ele está em um processo, assim, retardatário em relação às outras crianças. Mas, eu sei que, se você sentar, ele vai conseguir. Hoje, ele já pede pra ler uma coisa maior. Então, você vai lendo com ele, o Fernando também. Agora, a Lauriane é muito difícil. Hoje, eu entendo quando a professora falava que era difícil lidar. Porque você precisa de mais material e trabalhando que nem eu, trabalhando dois períodos, ás vezes não tenho tempo de chegar, preparar o material, fazer uma atividade diversificada com esses alunos. Não é por falta de vontade, você tem que ter tempo mesmo.

\section{P: E você tem feito coisas diversificadas ou não?}

S: Com a Lauriane, às vezes, eu faço; às vezes não. Com o Jordan, às vezes, eu faço; às vezes não. Aí, o Fernando vai fazer uma coisa, aí, eu leio com ele, às vezes... A maioria das vezes no que está da sala, aí eu vou e faço com eles. Vou lendo com eles. O Fernando não sabia fazer conta de dividir, aí, eu fui ensinando as outras, agora, eu comecei na dividir. Então, aí, eu comecei a ensinar pra ele dividir por dois números. Por um só, eu sento, vou na lousa, faço. Mas a Lauriane ela não busca, não porque ela não tem vontade. É dela, ela é tímida, tal. Aí, quando você vê, passa o tempo todo e: "Nossa, a Lauriane hoje ficou". Então, é muito difícil porque ela não busca. O Fernando fica em cima de mim o tempo todo. $E$, ou você ajuda, ou não ajuda. E a Lauriane não, porque ela não te pede ajuda. Ela senta. Aí, ela sentava aqui; aí, eu coloquei ela do outro lado. Aí, eu falei: “Oh, Talita você vai ajudando". Aí, outras crianças ajudam. Mas, assim, ela não tem o conceito de unidade, ela não tem o conceito de dezena. Então, pra ela, isso aqui é um monstro, está muito além. O Jordan, eu expliquei uma vez, ele pegou um pouquinho mais. Ele sabe dez. Eu sei que ele não construiu o conceito de dezena mesmo, do que é centena. Mas, o processo, se ele tiver que se virar, ele faz. Mas, daí, do Jordan, o que eu acho difícil de lidar é que ele pede atenção cinco horas por dia! Então tem dia que ele chega, tem que vir de uniforme, ele vem sem, porque ele quer que você fale que ele está sem o uniforme. Aí, ele traz o caderno, aí, ele não usa o verso, mas ele quer que você fale que é pra ele usar. Aí, às vezes, você tem que ignorar o Jordan, pra ver se ele faz a atividade, porque senão ele fica atormentando, mesmo, pra não fazer. Ele é difícil nesse ponto de lidar com ele. Mas, se ele está fazendo, ele pede ajuda. Se ele está a fim de fazer, ele pede ajuda. Ele senta; aí, você explica. Mas o dia que ele vem mesmo a fim de chamar a atenção, se ele ouve você falando assim: "Olha, você não faz isso"; aí, ele vai e faz, porque ele espera que você chame a atenção dele. Então, isso é difícil de lidar com ele.

\section{$P:$ E como é que fica o caderno desses alunos?}

S: Olha, o caderno do Jordan não tem organização nenhuma. Não tem uma seqüência. Ele usava dois cadernos, aí, eu falei pra ele usar um só e que não precisava separar as disciplinas.

P: E o restante da sala usa quantos? 
S: Eles usam ou de dez matérias, ou eles usam brochura e separam por disciplina. Só que o Jordan não consegue ter esse conceito: agora é matemática, agora é português. Aí, misturava tudo, pulava folha. Falei: “Jordan, usa um caderno só!”. A Lauriane separa já, ela já sabe separar. O Fernando também separa, então ele usa o de dez matérias, não tem essa dificuldade de se virar. 0 do Fernando é organizado. Quando ele vem, porque ele falta muito!

\section{P: É raro eu encontrar com ele}

S: Falta demais, demais. E aí, o caderno dele é assim: quando ele vem, tem as coisas. Ele faz. Ele é muito birrento, assim, sabe? Se chamar atenção, ele abaixa a cabeça, fala que não vai fazer. Outro dia, ele jogou comida fora. Aí, eu falei: “Agora pode entrar!”. Ele pegou e ficou bravo, e eu falei: "Não adianta você ficar bravo, não fui eu que fiz coisa errada. Você vai ficar aí emburrado, quem vai perder é você!”. Aí, ele voltou um pouquinho e fez. Ele é muito de ficar emburrado, de não querer fazer. Aí, você chama a atenção, aí eles ficam boquejando, sabe? Aí, eles não fazem pra te pirraçar. Daí, eles não vão fazer, eles não pensam assim: "Sou eu que estou perdendo, eu que não estou fazendo". Daí, eles não fazem pra ver se eu vou ficar brava, se eu vou chamar atenção. Tem horas que eu não chamo. Dessa turma, eu pego mais no pé. Mas, no ano passado tinha aluno que não... Mas, se você fosse cobrar dele o fazer no caderno, você não fazia outra coisa! Eles não faziam. Esse menino que o caderno dele ele arrancava folha. Ele hoje escrevia de azul, de vermelho, não encontrava nada naquele caderno. Mas, ele não aprendia no caderno dele, ele aprendia na oralidade mesmo. E tinha um outro que...

\section{P: Mas ele aprendia?}

S: Aprendia! Quando você... Eu lembro que eu ensinei conta de dividir... (entra algum aluno na sala e Silvia conversa com ele) Quando eu ensinei conta de dividir, se ele fez três contas no caderno foi muito! Aí, ele foi pra lousa, aí, eu fazendo a correção ele participava, e depois ele pegava e até ensinava para as outras crianças. Mas, se fosse ver pelo caderno dele, não tinha! Tinha um outro que já não sabia, que não queria fazer. Porque a gente lida com criança que não quer fazer. Não fazia e não tinha no caderno. Então o caderno, assim, começava a copiar da lousa, aí pula aquele espaço, aí depois, sabe, começa outro dia, não tem uma seqüência. Não acha nunca nada no caderno, então aí o caderno é menos significativo ainda. Então, ele não aprendia nem na oralidade e nem no caderno. Aí, por mais que eu cobrasse dele, aí chega uma hora, que a gente é pessoa, né? (risos) Que você vai ficando meio bronqueada com aquele aluno. Aí, você fala: "Ai, eu não vou mais dar murro em ponta de faca!". Então, ele chegava e eu falava: "Você vai fazer hoje?". Aí, ele começava... Aí, só que esses alunos, o que eles fazem? Eles não aparecem no aprender, mas eles aparecem na briga. Aí, briga. Brigava, batia, xingava. Aí, você tinha que separar. Então, aqui na sala eu cobro mais caderno que o ano passado. Porque era uma coisa que eu pensava, e eu falei: "Não, tenho que mudar." Porque eu já construí, né? Sou mais velha, eu já fiz esse processo de escola, então eu comecei a cobrar mais do caderno deles. Mas, o ano passado, eu não cobrava. Quando eu dei aula pra primeira série eu fui uma catástrofe em termos de cadernos. Porque era uns cadernos assim que eu olhava... No final, eu tive um resultado bom. Mas, em termo de caderno, não cobrava, assim, mais capricho, que eles tivessem mais organização. Pra mim era o fazer, o participar. Tanto que barulho, minha sala era número um, né?

$P: E$ no que você acha que isso é importante?

S: Do caderno você que você fala?

P: É, que você passou a cobrar mais. No que você acha que isso é importante? 
S: Eu passei a cobrar, como se fosse pra eles estudarem. Mas, no fundo, no fundo, no fundo (riso), eu acho que não é no caderno que está!

P: O que eles estudam?

S: (Estala a língua, em negativa)

P: Quando tem prova por exemplo? Como eles estudam?

S: Eles não estudam! (Responde rapidamente)

P: Você marca a prova?

S: Marco! Tal dia vai ter prova. Vai cair isso, isso e isso! Aí, chegam aqui e eles não sabem porque eles não estudaram. Teve um dia que eu marquei prova em um dia, não dei, não dei no outro, eu fui dar a prova uma semana depois. E eles foram mal, assim, que teve criança que tirou zero na prova. E aí, não estudou, ou também estou indo pela questão nervosismo, ou não leu a questão. Sei lá! Aí, o caderno, para eles, eu acho que não tem a mesma função que tinha pra mim quando eu não tinha livro. Então, quarta série que você começa a ter noção de mais do que é estudar em casa, e que também não era estudar em casa. Oitava, colegial, o caderno tinha função pra mim que, quando tinha prova, tinha que estudar! Mas, depois, na faculdade, o caderno... Aí, eu estudava pelos textos, não estudava mais pelo caderno. Eu falava que eu anotava por desencargo de consciência. E pra eles, eu acho que o caderno não tem esse: "Ai, é meu caderno! Vou olhar que eu aprendi isso, aquilo...". Fica mais o que foi discutido do que o caderno. Ontem, na segunda-série, tem uma menina que não pára, né? E corre... Aí, eu falei: "Pára menina! Por que você não pára um minuto?" E eu tinha dado um texto para eles e tinha uma menina Carolina. E a menina era a Jussara. Aí, eles falaram: “Ah, é a verdadeira menina Carolina!”. Foram falando partes do texto, certinha assim, aí eu achei aquilo interessante. 0 que eu acho que marcou foram as atividades, e não o registro no caderno. E eles falaram, assim, certinhas as características da menina, o que a menina fazia, que a menina falava que ela comia um monte de banana e depois ia parar na cama! "Olha a Natasha!" Eles fizeram a relação certinha! Mas foram as atividades e não o registro no caderno. Porque ninguém pegou o caderno e foi olhar. Foi a memória que trouxe! Eu falei só "menina”. Na hora que eu falei "menina”, eles lembraram. Um lembrou, outro lembrou... E foi completando o texto, e quase eles formaram o texto, completando as características da menina! Sem que eles procurassem no caderno... Às vezes, e foi até você que deu, pra gente marcar a data, que o caderno era um instrumento de pesquisa, tal. Eu comecei apensar nisso! Mas, eu sinto que eles não têm essa relação, sabe? 0 caderno chega em casa, vou jogar em qualquer lugar. Depois, eu vou usar, isso pra mim não tem importância.

P: E você vê algum caminho? Você acha que teria algum jeito pra fazer isso?

S: Pra que eles estudassem?

P: É. Pra que eles valorizassem mais o conteúdo dos cadernos.

S: Eu acho que as aulas da gente tinham que ser mais interessantes. (riso)

$\mathrm{P}:$ Você acha que é isso? 
S: Ah, eu acho! Porque se tivesse coisas mais interessantes mesmo, acho que produção, sem que o aluno tivesse a relação com o professor, com aquela coisa de broca, de cobrar, de estar errado... Eu acho que tinha essa função. Porque eles constroem isso. A gente chega perto... No ano passado, chegava perto do menino ele tremia assim, olha, nervoso! Eu falava: “Não precisa ficar nervoso, eu não vou brigar, eu só estou te ajudando!" Então, eu acho que é isso: se as aulas fossem mais dinâmicas, se a gente conseguisse fazer aula mais legal, assim, menos igual! Tem aula que nem eu agüento. Eu falo: “Está muito igual!". Quando eu dou aula de matemática, eu vou passar um problema, ai nem eu estou agüentando mais fazer isso. Eu acho que pra eles também é chato, eu falo pra eles. Às vezes, o pessoal comenta: "Barulho!". Eu falo: "Oh, gente, quando eu vou num curso e não gosto, eu fico insuportável, porque eu converso mesmo". Imagina eles ficarem cinco horas sentados. Aí, o caderno fica um porre. Então, eu acho que a aula tinha que ser mais interessante. Nós, professores, tínhamos trabalhar um período e o outro preparar pra o outro dia. Mas, ir buscar. Porque hoje a gente fala, assim, pra matemática, que muita coisa está mudando, que a gente aprendeu (de modo) mecânico, eles não tinham que aprender mecânico. Mas eles têm que quebrar uma barreira entre como você aprendeu e o jeito que vai ensinar. Só que, aí, você não consegue sair daquilo. Só que, aí, você não tem tempo de elaborar coisas melhores e acaba ficando maçante e igual. E aí, o caderno fica o quê? "Ah, eu vou passar logo o que a professora faz, pra ela não me encher, pra eu deixar meu caderno organizado." Eu acho que é isso! Infelizmente é isso!

\section{P: Entendi.}

S: Por isso, que não tem essa relação gostosa com o caderno. Falta preparo nosso, do professor mesmo. A gente acaba caindo no como a gente foi ensinado. $E$ a gente quer trabalhar no silêncio, não ter barulho. Dar uma atividade que tem barulho: "Ai, o que vão achar da sua sala? Maior barulho!" Aí, você quer ver um registro também deles, mas eles fazem pra gente. Eles não fazem pra eles: "Eu vou fazer pro professor". Por isso que, quando eles escrevem um texto, eles não lêem pra perceber que tem palavra ali que está faltando letra e que ele não está entendendo. Porque quer entregar logo pra ficar livre. Quanto mais rápido ele fizer, pra ele é melhor. Eu acho que é isso! isso?

P: E você consegue usar quanto desse registro que eles fazem pra avaliação? Você usa

S: Eu uso não os cadernos para a avaliação. Nem a prova, assim. Eu uso o oral deles, quando eles falam alguma coisa, quando eles vêm fazer alguma coisa sozinho. Então, eu dei um tipo de uma conta, assim. O caderno, eu sei que quando ele traz e está conseguindo fazer. Ali, assim. Eu não avalio, igual tem professor que dá nota pelo caderno. Falar assim: "O caderno mais organizado vai ganhar isso", eu não acho justo! Tem gente que não tem o dom de ser organizado, tem letra bonita. Eu mesma, eu acho que meu caderno não era organizado, bonito. Então, eu de observar mesmo, se está fazendo, se está pensando. Que nem as situações-problema, eles têm dificuldade de interpretar. E eu falo pra eles: "Quando vocês lêem não começa a vir um monte de conta na cabeça de vocês? Como é que funciona?".

\section{P: Quando eles lêem os problemas?}

S: Isso! Eu falo assim pra eles... Tem uma atividade de sexta-feira que chama desafio. Se eu recebesse aquilo, eu ia tentar de todas as maneiras. E eles ficaram muito bravos comigo sexta-feira, porque eles vinham e eu falava que não era. E falava: "Gente, é tabela, olha o dobro!". Teve criança que queria me socar aqui, você olhava. Eu vejo assim, que falta o pensamento pra eles, assim. Quando eu vou avaliar, eu não posso contar a prova, aí é no 
dia-a-dia mesmo; “Ah, hoje conseguiu fazer, está participando, o oral, o que fala. Vem na lousa, e aí faz sozinho." Eu faço essa avaliação, assim, sem... Se eu pegar um caderno que é desorganizado, e for olhar por aquele caderno... Eu vou usar o aluno do ano passado, aquele menino ia tirar zero. Mas, eu sabia que ele sabia, porque uma criança que ajuda o outro, que fala, que discute o que está errado. Então, é nisso que eu uso. Mas, o caderno, assim, não consigo ver. Porque eles não têm uma relação boa com o caderno.

\section{$\mathrm{P}$ : Você tinha falado da gincana né?}

S: Então, e aí, a gincana, que eu fiz.Porque quando eu fiz a prova, eu vi que eles não tinham ido bem, eu falei : "Vou fazer essa gincana de conhecimento pra ver se eles estudam em casa, e pra ver como é que é." Aí, as perguntas foram bem fáceis, assim, não tinha nenhuma absurda. Eles se organizaram, fizeram. E eu senti que eles gostaram de fazer, tiveram prazer em responder certo. E também tinha a questão da competição. Mas tinha o prazer de mostrar para o outro. "Olha, eu sei, mas você errou!". E aí aquilo valeu muito mais como construção de conhecimento, do que um registro no caderno. E hoje eles estão cobrando. Que empataram três grupos e, segunda-feira, eu vou fazer outra. Mas, daí, vai participar todo mundo. Eles vão continuar com aquela pontuação pra gente ver quem ganha. Aí, eu vou tentar introduzir perguntas mais difíceis, pra ver se no grupo eles conseguem discutir e responder. Que nem o grupo do Jordan, eu soltei uma pergunta e ele já foi respondendo. Porque daí você trabalha em interação, cooperação. Eu falei pra eles, que trabalho em grupo não funciona. Quando eu trabalho em grupo, você sai daqui nervosa! Porque senta quatro, mas eles não têm aquela responsabilidade: "Nós quatro que estamos fazendo. É um produto!" Você vai corrigir e aí faltou uma letra: "Não, foi ele que escreveu! Ele que errou!" Eles não têm essa noção de que o grupo fez e que, se for nota, a nota vai ser do grupo. "Não, ele que escreveu!". Daí, o outro anda: “Ai, ele não está fazendo nada!". Eles não têm essa organização de grupo, de entregar um produto só. Eles não conseguem entender isso. Aí, na gincana, já foi melhor! Porque daí um foi perguntando pro outro...

(A entrevista é interrompida porque as crianças voltam da aula de Educação Física. Entram na sala, falando alto, cantam para o gravador. Combino com Silvia continuarmos a entrevista na próxima semana.) 


\section{ANEXO D \\ TRECHO DE ENTREVISTA EM DUPLA COM ALUNOS}

Transcrição da Entrevista de Leonardo e Cleber

Leonardo: (L)

Cleber: (C)

Pesquisadora $(\mathrm{P})$

Natali: (N)

Parte I

P: Ela sabia que vocês vinham?

N: Vou filmar um pouquinho só pra vocês verem!

(Eles ficam quietos esperando a Natali filmar. Todos riem após alguns segundos. Cleber põe a mão no olho).

C: No meu aniversário, aquela filmadora na minha cara!

P: Na sua casa? O pessoal filma também? (Cleber concorda com a cabeça)

L: Uma vez no aniversário, meu pai...

P: No aniversário de quem, Lelê?

L: No aniversário do vizinho!

P: Pode chamar você de Lelê?

L: Pode!

P: Todo mundo chama, né?

L: É!

C: É o nome. Desde a primeira série, né, Lelê?

P: Vocês estudam juntos desde a primeira?

C: Não. Nós só paramos um ano na segunda série.

L: No ano passado!

C: Nós estudamos na primeira com a Janete, né?

L: Não!

C: Não. Da Célia! 
$P:$ Ah, eu lembro da Célia, ela não está mais na escola, né? (Cleber confirma com a cabeça que não)

L: Aí, depois, a Ligia.

C: Depois, a Ligia...

P: Com a Ligia vocês estudavam juntos?

L: Na segunda.

C: É. Aí, depois, nós ficamos separados, eu repeti!

L: Eu também! (Lelê dá um sorriso)

P: Os dois repetiram? (Eles concordam com a cabeça)

C: Aí, eu fiquei na Miriam e ele estudou de manhã! Daí, voltou com a Janete e agora a quarta série.

P: Vocês são muito amigos? (Respondem que sim com a cabeça)

$P$ : E qual foi a série que vocês repetiram?

C: A segunda!

P: E vocês combinaram de repetir? (Risos)

C: Olha que na última prova a gente tirou a mesma nota...

L: Nota cinco!

C: É. E ela falou que quem tirasse menos de seis repetia! Estávamos, eu e o Lelê, sentados na carteira um do lado do outro, a gente se esforçando. Daí, a Dona falou: “ Lelê, cinco!", aí ,o Lelê já abaixou a cabeça. Daí, já estava assim meio, aí, "Cleber , cinco também!". Daí eu falei, nossa, combinamos, Lelê, de repetir! Aí, agora,vamos ver se agente passa.

L: A gente fazia muita bagunça!

P: Foi?

C: Bilhete não faltava no caderno!

P: Sério? E como é que era?

C: Era só bagunça. E aí, a professora pediu meu caderno. Estava nervoso aquele dia, né, Lelê? Tinha acabado de chegar da diretoria. Daí, ela pediu. Daí eu: "Eu não vou dar o caderno não, já enjoei!". Daí, eu bati o caderno na carteira e fez aquele barulhão. E ela falou: "Deixa a Rosa aparecer aqui na porta que você vai ver!" Daí, o Lelê, falou: "ih, vem vindo a diretora". Daí, eu falei: “ ó dona pode ir fazendo o bilhete”. (risos) Ela chamava a minha mãe, e de vez em quando ela vinha... 
L: O dia que eu briguei com Régis, ela estava pedindo meu caderno. Aí, eu não dei, não.

P: Não?

L: Não!

P: E o que acontece se não dá o caderno?

C: Vai pra direção!

L: Suspensão! Às vezes, né?

$\mathrm{P}:$ Aconteceu isso com vocês?

L e C: Não!

C: Até agora na quarta série, não.

P: Lelê falou que não deu uma vez. Mas, daí, deu suspensão? (Lelê faz com a cabeça que não) Mas, corre o risco?

C: Não, que nem, o Lelê estava sentado, aí o moleque pediu a borracha pra ele. E o Lelê: "Não, não vou emprestar. Estou usando". Aí, o que ele fez? O Lelê estava de costas, ele veio e grudou no Lelê pelo pescoço. Ah, mas foi uma briga. Daqui a pouco o Érico veio e deu uma na boca do estômago. E o Lelê ficou nervoso já deu outra nele. E aí, começou. Aí, a professora perguntou pra todo mundo. E aí, quem estava errado era ele e não era ele. ( indicando que Leonardo não estava errado) Porque quem levantou ... "Então, quem vai tomar suspensão é você" Aí, o moleque tomou ficou dois dias sem vir pra escola. E esses dois dias, ele perdeu duas provas, que era de matemática e ciências!

P: E esse ano, vocês já levaram muito bilhete?

C: Não.

P: Tem aí no caderno? (Eles pegam o caderno) Posso ver?

L: Eu só tomei um!

P: Um só?

C:

L: Que caderno?

P: Ah, pega tudo. Pega tudo que vocês tiverem pra gente ir olhando. (pausa no diálogo, eles pegam os cadernos)

C: Eu só tenho...

P: Qual que você trouxe? 
C: Ah, eu trouxe o de português velho.

$\mathrm{P}:$ Nossa vocês trouxeram um monte deles!

C: Mas metade é de matemática.

L: Trouxe também um de...

C: História.

L: Matemática, eu joguei.

P: Você jogou fora?

C: Ciências. Aí, o outro novo. Aí, aqui é o do Educando para a vida!

P: Esse aqui é o de Historia. E esse aqui do que que é?

L: Caderno de português

C: Não!

L: De matemática!

C: Quer ver? Eu acho que o bilhete está aqui! (Cleber procura folheando seu caderno) Não. Não é esse.

P: O Lelê não tem mais o bilhete porque ele jogou fora o caderno! (riso)

C: Eu tenho! (Eles procuram) Esses dias mesmo eu andei mexendo no meu caderno . (Cleber procura em seus cadernos os bilhetes) Na terceira série, eu arrancava os bilhetes que a professora mandava.

P: Você arrancava? E aí? (Risos)

L: Quando ela mandava em umas folhinhas que amassava tudo.

P: Jogava fora? A professora via?

C: Ah. Era o de ciências!

P: E a mãe de vocês via?

C: Via! A minha via! Ô meu Deus, tem que estar em um desses. (Cleber continua procurando um bilhete que quer mostrar)

P: O que a mãe de vocês acha quando tem bilhete?

C: Aí, o comportamento como é que anda!

L: A minha mãe, às vezes, fala assim: "Se tomar outro, vai apanhar!" Ela fala brincando. Aí, às vezes, eu tomo outro e ela não fala nada! 
P: Não! Mas já apanhou por causa de bilhete?

L: Muitas vezes. Uma vez o Cleber veio com o braço tudo cortado aqui assim (LEONARDO faz o gesto. Riso)

P: Foi? (Eles concordam) E isso foi de bilhete?

C: Foi!

P: esse ano?

C: Não, esse ano não. Foi no comecinho do ano.

P: Foi com a Silvia?

C: Não. Foi com a professora nova, com a Malu! (Cleber ainda está à procura do bilhete) Ah, sumiu. Mas, esses dias, eu estava... Eu ainda li pra minha mãe... (folheia todo o caderno) Não está!

P: Não achou? (Cleber faz um não com a cabeça e parece ficar desapontado) Bom, se achar, a gente vê! Mas o Lelê estava falando que joga o caderno dele fora, você joga todos fora?

L: Ah, uns acabando eu jogo!

P: E acabou, você joga fora? (Leonardo concorda)

P: Não tem nenhum que você guardou? (Leonardo faz um não com a cabeça)

$P:$ E por que você joga fora?

L: Costume...

P: Costume! E depois que acaba, você acha que serve pra alguma coisa?

L: Pra mim, não!

C: Pra mim, eu acho. Eu guardo pras minhas irmãzinhas que estão indo pra quarta.

L: Meu irmão já está na quinta. Minha irmã ia terminar, não terminou. Outra irmã está terminado.

P: A tua outra irmã vai terminar o quê?

L: Terceiro.

P: Ela não terminou? (Leonardo faz que não com a cabeça) Por quê?

C: Meu irmão parou no quarto.

P: Ela foi embora da escola?

L: Saiu de casa. 
$P:$ Ah é? E você sabe dela? (Leonardo faz que não) E ela é nova?

L: Não.

P: Quantos anos?

L: 20 anos!

$P:$ Ah, é moçona, já.

L: Já tem um filho, já.

P: É?

C: (Cleber ainda procura em seu caderno o bilhete) Estava no de português. Um dia, eu estava no começo do ano...

P: E você? Você guarda, né, Cleber?

C: Eu guardo!

P: Você guarda todos? (Cleber confirma) Desde o comecinho? (Cleber confirma)

C: Eu tenho um lá da terceira série. Aquele lá, grandão, da feiticeira.

P: Da feiticeira?

C: Um grandão!

P: E pra que que guarda?

C: Ah, porque minha mãe mandou. Ela já é acostumada!

L: Uma vez, minha mãe falou pra eu guardar. Daí eu guardei, guardei, guardei... E aí, ela estava limpando e jogou tudo fora!

P: E por que será que ela falou pra guardar aquela época?

L: Sei lá! Ela falou: “Guarda!”, aí eu guardei!

P: E você fez alguma coisa com ele?

$\mathrm{L}$ : Ah, às vezes, tipo assim, eu deixava dentro da bolsa, e quando a professora faltava, eu estava na segunda, pra terceira série, aí pegava o caderno, via alguma coisa que eu não sabia, pra aprender de novo, aí eu fazia.

P: Ah, mas quando você voltava pra serie que você já tinha feito?

L: É!

$\mathrm{P}: \mathrm{E}$ isso acontecia muito? 
L: É!

C: Aqui, olha, achei!

P: Ah. E pode ler?

C: Pode! Mamãe, ando me comportando de forma indisciplinada dentro de sala de aula. Não respeito a professora nem meus colegas. Seu filho, Cleber. Hortolândia, dia 2 do 8 de 4. Assinatura do responsável. Minha mãe assinou! Foi bem no comecinho do dia 2 do 8 , bem...

P: Você lembra o que tinha acontecido nesse dia?

C: Eu tinha.... Estava uma bagunceira dentro da sala, quase todo mundo levou um bilhete desse, não foi?

L: Só eu que não!

P: Você não levou?

L: Eu fui esperto. A professora falou... Apareceu na porta e falou assim: "Quero saber quem está gritando". Daí, eu sai correndo e sentei na carteira, e abaixei a cabeça.

C: Não! Você tinha falado: “ Professora, posso ir no banheiro?”, e, a hora que ele voltou, a dona já estava com os cadernos assim na mão.

L: Aí, eu estava com o caderno na mão, aí eu fiz bagunça.

C: $\mathrm{E}$ aí, ele tomou!

L: É, eu tomei!

C: Ele ficou lá, falando: “Eu não tomei, eu não tomei”. "Leonardo traz seu caderno aqui!". Ele: "Tó". Daí, ele trouxe. A professora deu o bilhete só porque ele falou que não tinha tomado! (risos)

L: E um dia, esse dia aí, estava eu e o Edieverson lendo uma história lá, 'Cobra cega' (risos de ambos). Aí, eu estava lendo e terminei, e todo mundo bateu palma. Só ficou o José batendo palma. Daí, a professora...

\section{C: "Pode continuar!"}

L: “Pode continuar”. Daí, ela mandou parar de bater palma.

C: Aí, o Lelê lá, continuou a bater palma e quase todo mundo... Aí, quase metade da sala continuou batendo também. Professora falou: "Quer todo mundo entrar no ritmo? Eles dois param e vocês continuam?" Aí, eu peguei meu caderno e comecei a fazer a lição. Só vi o Lelê lá. (fez gesto de bater palma) Aí, eu falei: “Ô, professora, já enjoou já!”. "Não. Ele vai continuar mais ainda." Aí, era uma e meia. Deu duas horas e parou! Porque a professora enjoou!

P: Ficou meia hora batendo palma? 
C: Ele e o José. Que nem a professora falou: "Vamos bater palma". Aí, bateu. Aí, terminou e o Lelê continuou. Aí, ela: "Vai ficar continuando". Aí, era uma e meia; deu duas horas, eles pararam! Se não, eles vão ficar até a hora do recreio, até às três e meia, batendo palma!

$\mathrm{P}$ : Já pensou ficar até as três e meia batendo palma?

L: Vai lá. Bem desse jeito assim... Ainda cantando musica do Bate Lata.

C: É! Cantando a musica do Bate Lata. Aí, ela: "Vocês não vão mudar de ritmo, não!". Aí, eles: "Uá, uê... Aí, eles mudaram e a professora: "Pode voltar naquele ritmo normal, mesmo. Parem de cantar essa musica.”. Daí, os dois pararam.

P: E tinha que cantar a musica?

C: Não, a professora não queria!

P: Não podia cantar!

C: Só podia bater palma. Aí, o Zé falou: "Vamos cantar um auê, aí” A dona ouviu e ela falou: "Pode parar. Eu só quero que batam palmas!" E aí, os moleques começaram a bater na carteira também. Aí, ela falou: “Não pode bater na carteira também!”. Aí, todo mundo parou. Aí, deu duas horas eles pararam também. Foi até o fim, né? Aí, eles nunca mais fizeram isso. Que nem, termina de bater palma e os dois terminam antes.

P: E me conta uma coisa, o que que pode e o que não pode fazer na sala de aula?

L: Não pode brigar. Respeitar a todos.

C: Respeitar os funcionários. Respeitar as professoras, os colegas, as diretoras também, gente de fora também, deixar a sala limpa...

L: Não escrever...

C: Não escrever nas carteiras. Que nem esses dias atrás, nós andamos limpando. Estava branca. Nós limpamos na quarta, né? Foi em uma quinta, e aí, já estava tudo suja. E aí, a gente conversou com a diretora, e a diretora falou que ia dar uma bronca. E aí, na sexta, estava do mesmo jeito, ainda estava pior.

$P$ : E quem sujou?

C: Os alunos de manhã. Aí, limpou bem no finalzinho da aula. Aí, chegou na quinta feira e já estava tudo sujo de rabisco.

L: A gente rabisca também. Todo mundo rabisca a carteira.

C: Quando eles limpam de manhã, a gente rabisca à tarde.

L : Pra fazer conta na carteira.

C:É!

$\mathrm{P}$ : E pode rabiscar? 
C: Não!

P: E muda, de professora pra professora, o que pode fazer e o que não pode?

C: Não!

P: É igual? (Cleber concorda com a cabeça) Isso que vocês falaram pra toda professora é igual? (Concordam) E no caderno? O que pode e o que não pode fazer? (Risos)

C: No meu, esta tudo fora de ordem. Eu não gosto de rabiscar muito a carteira, daí eu vou arrancando folha.

L: Eu também, às vezes, quando são aquelas contas de dividir que eu não sei fazer, rapidão, eu pego e faço...Como diz? Na multiplicação.

P: E você vai fazendo no caderno?

C: É.

L: É.

C: A professora, nossa primeira professora, a Silvia, ela falou: "Se vocês não souberem..." Que nem, estava 284 dividido por 3. A gente pega e vai dando, até chegar no resultado. E tem que chegar perto e não pode passar!

L: Tem que dar o número sem passar!

C: Se passar...

L: Se tem que dar um número, então não pode passar. 0 número pode ser uns três números antes.

C: Que nem, se for 800 , se dá 700 , pode! Só não pode passar!

P: Isso foi um negócio que vocês aprenderam com ela?

C: Com a Silvia!

L: Agora, esqueci um pouco.

C: Que nem, nessas férias de julho, a professora perguntou: "Quem sabe fazer conta de dividir?". Só o Uelinton, só, que levantou a mão, porque quase toda sala já tinha esquecido! Daí, ele: “Eu sei, professora!”. Daí, ele foi lá e fez uma! Daí, depois, ela deu de novo.

P: E ele fez certo?

C: Fez certinho! Está acostumado já. Ele e o Edieverson, eles que mais sabem mais nessa aula.

L: O Edieverson antes era só...

C: Era só nessa aula... 


\section{P: E agora? \\ C: Agora, está só com seis. Na prova de português, ele tirou cinco! O Uelinton tirou} oito!

L: Eu pensei que eu tirar três. Tirei seis!

C: Eu também tirei seis!

P: Foi?

C: Na de português. Na de matemática, eu errei dois! Eu e o Uelinton, a gente errou dois. Aí, era pra eu tirar nove, e ela deu oito, e pro Uelinton deu nove. O meu estava uns oito números e do Uelinton só estava dois! Daí, ela falou "Pra você, vou dar oito e pro Uelinton nove, porque o seu estava muito depois!". Porque, que nem, era pra dar 848 e no meu deu 899.

P: Ah, tá.

C: E no do Uelinton estava mais pertinho, assim.

P: Você achou justo?

C: Não. Eu nem liguei! E aí, ela falou: “Ó, você não se preocupa não, porque você ainda está na lista de passar!”. Aí eu falei: “Ah, então está bom!”

P: Lista de passar e de não passar de ano?

C: Mas, mesmo se eu não passar, eu acho que eu vou ficar até o dia 17.

L: Eu acho que eu não vi ainda, não!' cabeça)

P: A de matemática você ainda não sabe quanto você tirou? (Lelê faz não com a

$\mathrm{P}:$ A de português você tirou quanto?

L: Seis!

C: Seis! Eu tirei seis! Eu tirei oito e seis, eu acho que vou conseguir passar...

P: Oito na de português? Não...

C: Não. Oito na de matemática e seis na de português...

P: Você tirou seis na de português.

L: Na de matemática, não sei ainda não!

P: Você acha que foi bem?

C: Esses dias aí atrás, eu tinha visto a prova dele, mas eu não lembro o número. 
P: É?

C: O Ralph faltou e eu estava sentado no lugar dele. A professora corrigiu. Aí, a gente estava lendo os nomes. E daí, deu o do Lelê. Aí, na hora que deu do Lelê, eu pedi pra ir no banheiro, daí eu não vi a nota!

P: E o que você acha? Você acha que, na prova, aquilo que sai, é aquilo que você sabe, mesmo? (Cleber confirma)

C: A professora fala: “Ah, você pode fazer com calma”. Daí, ela dá a uma, aí fica até as duas, quatro horas fazendo prova, né, Lelê? Daí, dá cinco horas e ela fala: "Olha, a aula hoje é só pra dar a prova mesmo". Daí, ela solta a bola na quadra.

P: Depois da prova?

C: Ela falou, assim, que se a gente terminasse até as quatro... Aí, deu quatro, a gente já tinha terminado. Daí, ela falou: “Cleber, vai lá e busca a bola de queimada”. Daí, eu fui lá, peguei a bola pra professora.

P: E vocês tinham estudado pra prova?

C: Não, pegou desprevenido! Ela catou assim, que nem, em uma quarta-feira, ela não falou nada. Aí, ela chegou e falou: "Separa as carteiras". Estava junto. Ela: "Separa!". Daí, a gente separou e ela começou a dar as provas.

P: E aí?

C: Logo a de português. Mas, assim sem...

L: Todo mundo pedia: "Quero uma prova”.

C: É. Daí. o Ralph: “Ai, professora, quero uma prova, quero uma prova”. "Eu vou catar vocês um dia desprevenido" Aí, chegou: "Separa! Separa!” Daí, nós já começou. Daí, o Ralph viu: "Mas, professora, é de português? Eu pensei que era de Matemática!". "É, mas a de matemática eu vou catar desprevenido também!". Passou dois dias depois, e ela foi lá e deu a prova de matemática! E daí, como ela já tinha falado que ia catar desprevenido, eu estudei. Daí eu tirei um oito, era pra tirar um sete! Se eu ... Que nem, eu errei só duas, eu e o Uelinton. Aí, eu somei o número e deu errado, deu 73 era pra dar 146 ou 143. Aí foi, eu somei de novo, aí deu o resultado e eu deixei, né? Aí, a dona tinha visto que eu tinha errado, estava o 73. Eu tinha apagado bem de vagarinho. Aí, mostrou, ela tinha visto o 73 e ela falou: “Ê, Cleber, escapou pelo fio, hein!” Eu falei: “Por que professora?”. Ela falou: “Porque em vez de 143, você tinha colocado 73". Aí eu falei: “É pra você ver como é que é!”. Daí ela falou: “Tó!”. Daí ela deu certo!

P: Você tinha estudado?

L: Não!

P: Estava desprevenido? (Leonardo faz que sim com a cabeça)

C: Ela catou as duas desprevenido...

$\mathrm{L}$ : A de português, pelo menos, a gente leu um texto. 
C: A de português ela ajudou, a de matemática também! Mas, só foi ler, porque estava meio apagado o texto!

L: O Gustavo só queria copiar!

C: O Gustavo e o Alan! Os dois queriam copiar.

L: Quando é prova, assim...

P: Copiar de vocês? (Ambos concordam)

P: Pode?

C: Não!

P: Não pode?

C: A professora não gosta, porque cada um tem uma aprendizagem. Porque, a gente faz lá. Aí, ele não está pensando em colocar o resultado. A gente pensou, fez o cálculo. Ele não está fazendo. Está copiando de nós, ele não está pensando da cabeça dele. Esses dias atrás o Alan andou copiando, e a professora pegou as provas e foi olhando, daí ela pegou a do...

P: Alan Raul?!

C: É, Alan Raul. Daí, ela pegou a do Gustavo e a do Alan. Aí, ela olhou, estava escrito tudo igual. Aí, ela chamou os dois! Aí, quase que o Gustavo teve que fazer outra prova, né? Aí, foi o Alan que fez!

P: Aí teve que fazer outra?

C: Aí separou. O Alan ficou _.

P: E quem tinha copiado de quem?

C: O Alan copiou do Gustavo!

P: Foi?

C: Foi! O Alan ia toda hora: “Ai, empresta a borracha.” Daí, ele ia, olhava e copiava. Daí, a professora foi ver a dele, aí olhou a dele e a do Gustavo, e aí deu tudo junto!

P: Entendi!

C: Aí, ela falou: “O, Alan, vem cá!”, chamou ele e o Gustavo. Daí, ela falou: “Essa prova é sua, Gustavo?", ele falou: “É!”, “Essa é sua, Alan?”, ele falou “É!”, “Por que que está igual?". “Ah, sei lá, professora!”. "Alan, cata essa prova e vai fazer lá do outro lado!” Ele catou e foi do outro lado, e deu tudo errado a dele.

P: Ele foi mal?

C: Ele tirou cinco na de português! Pode repetir, se a professora quiser. 
P: Quanto que precisa tirar pra passar?

C: Oito pra cima!

P: Oito pra cima?

L: Oito ou cinco?

P: Oito ou cinco?

C: Não. Que nem de seis pra cima. Não pode ser de cinco pra baixo, que já é nota baixa!

$\mathrm{P}$ : Se tirar seis passa?

C: Passa!

P: Se tirar sete?

C: Passa! Oito, nove, passa!

$\mathrm{P}$ : Se tirar cinco e meio, passa?

C: Passa!

P: Passa?

C: Passa!

P: Passa, Lelê?

L: Eu acho que passa!

P: E se tirar cinco?

C: Não! Aí, fica no meio a meio! Aí, tem que ficar pra ver se vai aprender...

P: Então vocês que tiraram seis, oito, o que vai acontecer?

C: Aí, a professora vai pensar. Porque ela está em decisão, ainda, quem vai passar e quem não vai!

P: E o que vai contar além da prova?

C: Aprendizagem na sala de aula e o comportamento!

P: Como que ela vai saber a aprendizagem na sala de aula?

C: Porque ela olha o caderno todo dia. Quando a gente termina, ela fala: "Todo mundo que terminou vem e mostra”. Aí, ela vai olhando, vai corrigindo, vai dando as notas...

P: Ah... 
L: Toda a lição que a professora passa na lousa eu faço!

P: Todas?

L: Todas!

C: Todas! Eu não deixo nenhuma! Aí, olha, tudo certo! Isso aqui também conta na aprendizagem (Cleber pega um caderno e mostra à Anabela).

P: Então, se você tem um monte de certo no caderno, isso conta pra passar de ano?

C: Conta!

$P$ : Você acha que conta também, Lelê? (Leonardo responde que sim com a cabeça) $E$ vocês têm caderno bom?

C: Eu não tenho. A letra, a aprendizagem...

P: O Lelê falou que copia tudo e faz todas as lições.

C: Eu também!Eu vou lá e fico pensando.

L: Às vezes, assim, o José, eu vou lá e pergunto pra ele, às vezes. ajudar.

C: Tem vez que ela deixa fazer junto, em grupo. Aí um faz, se está errado, ela manda

P: Como que é isso? Na prova, vocês estavam falando que não pode copiar...

C: Não!

L: Só lição da lousa.

C: Na lição da lousa, quando está bem difícil mesmo, ela coloca uma que sabe e uma que não sabe, pra ficar mais já bem aprendido. Aí a gente vai indo, que nem, um faz, quando o outro faz errado: “Ah, você errou, tenta fazer de novo". Depois que está certo, ela vai lá olha.

P: E quem ajuda quem?

C: Ela coloca um aluno bom com outro ruim. Por exemplo, o Edieverson ela coloca com um moleque que não sabe; o Uelinton, que sabe, junto com que não sabe. Aí, vai indo, ela vai separando.

P: Você senta com quem Lelê?

L: Quando é assim, é eu e o Alan.

P: E aí quem ajuda quem?

L: Ah, os dois!

C: Os dois! 
L: Um pergunta pro outro, nós vai pensando e fazendo.

\section{P: E você?}

C: Eu sento com o Jordan! Que nem, ele não sabe muito conta de dividir. Eu faço e ele fala: "Deixa eu ver”, eu falo: “Não" Daí, esses dias, ele fez uma certa, só errou pelo número. Era pra dar 5 e deu 4. Aí, eu falei: "Ah, se você somar direito, aí a conta vai dar certa. É só você somar o último número!", ele somou e deu cinco, ele tinha trocado um número. Aí eu falei: "Aí, é só você pensar!". E na outra ele fez e deu a certa. Aí, eu falei: "Tá vendo? Viu como você consegue?". Aí, agora ele está sentando com uma pessoa que não sabe, porque ele já aprendeu já.

$P$ : E quem que fala com quem que vai sentar?

C: A professora! Ela coloca assim, os que não sabem! Aí, os que sabem, ela já deixa com uma carteira vazia. Que nem, o Jackson, o Jordan e o Lucas. "Jordan, você vai sentar com o Uelinton!”. Aí, o Uelinton vai ter que fazer. Daí ele vai lá e mostra pra professora. Se estiver certo, ela vai corrigir. Aí, ele vai voltar e vai falar pro Jordan. Mas, só que não vai deixar copiar, ele vai falar: "Você pega esse número e soma, e pega o outro e soma...". Aí, o Jackson: "Ah, você vai sentar com o Edieverson". Aí, ele vai lá e senta com o Edieverson! Aí, vem o Lucas, aí tem vez que ele senta até comigo. Só que, daí, o Jackson, o Jordan e o Lucas não podem ficar junto que dá confusão. Aí, o Lucas sentou comigo e fez tudo certo. Aí, a professora olhou no do Lucas e estava tudo certo! Aí, eu falei: “ Eu nem ajudei ele! Eu fui falando e ele foi fazendo."

P: E você acha que funciona isso de não deixar copiar? Todo mundo faz assim?

C: É porque tem que colocar a cabeça do outro pra pensar. Não é só a nossa, né? 0 dia que era pra fazer esse (mostra uma atividade no caderno), colocou tudo um ajudando o outro, aí a gente fez tudo.

\section{(Pausa para troca da fita)}




\section{REFERÊNCIAS}

ANDRÉ, M.E.D.A. (1983) Texto, contexto e significados: algumas questões na análise de dados qualitativos. In: Cadernos de Pesquisa, São Paulo (45) 66-71, maio)

. Etnografia da prática escolar. Campinas: Papirus, 1995.

ANTUNHA, E.G.G. Distúrbios de Aprendizagem: aspectos e terapêuticos. 1972. 236 f. Tese (Doutorado em Psicologia Clínica) - Instituto de Psicologia, Universidade de São Paulo, São Paulo.

BAKHTIN, M. Estética da Criação Verbal. $2^{a}$ ed. São Paulo: Martins Fontes, 2003.

BOCK, A.M.B. Psicologia da Educação: cumplicidade ideológica. In: Psicologia Escolar: teorias críticas. São Paulo: Casa do Psicólogo, 2003.

BOURDIEU, P. (Org). A miséria do mundo. Petrópolis: Vozes, 1997.

BOSI, E. (2003) O tempo vivo da memória: ensaios de Psicologia. São Paulo: Ateliê Editorial.

BUKIET, S.; MÉROU, H. Les Cahiers de la République. Paris: Alternatives, 2000.

CAMPOS, M.M.M. e GOLDSTEIN, M.S. 0 ensino obrigatório e as crianças fora da escola: um estudo da população de 7 a 14 anos excluída da escola na cidade de São Paulo. Educação e Desenvolvimento Social, São Paulo, Subprojeto 5, 1981. 
CARVALHO, M. P. Mau aluno, boa aluna?: como as professoras avaliam meninos e meninas. Revista Estudos Feministas. Florianópolis, v. 9, n. 2, 2001. Disponível em: <http: //www.scielo.br/scielo.php?script=sci_arttext\&pid=S0104-026X20010002 $00013 \& \operatorname{lng}=$ pt\&nrm=iso>. Acesso em: 12 Jul 2007.

CASPARD, P. Introduction. Histoire de l'Éducation. Paris: Service d'histoire de l'éducation de l'INRP, nº 38, p.3-6, 1988.

CERTAU, M. A invenção do cotidiano. Petrópolis: Vozes, 2005.

CHARLOT, B. Educação e Culturas. Conferência proferida no Fórum Social Mundial de Porto Alegre, 26 de outubro de 2001. Disponível em: <http://www.artmed.com. $\mathrm{br} /$ patioonline/fr_conteudo_patio.php?secao=627\&exibir=online_exclusivo>. Acesso em: 10 ago 2005.

CHARTIER, A.M. Un dispositif sans auteur: cahiers et classeurs à l'école primaire. In : Hermès, Le dispositif: entre usage et concept , Paris: CNRS, n²5, p.207-218, 1999.

. Fazeres ordinários da classe : uma aposta para a pesquisa e para a formação. Educação e Pesquisa, v.26, n.2, p.157-168, 2000.

. A propos des cahiers d'élèves. In: Kucera, M.; Rochex, Stech, S.; La transmission du savoir comme probleme culturel et identitaire. Prague: Karolinum, p.69-87,2001.

Um dispositivo sem autor: cadernos e fichários na escola primária. Revista Brasileira da História da Educação. nº 3, p. 9-26, 2002. 
.On écrit dans quoi, Madame? Cahiers et classeurs à l'école primaire, Repères, $n^{\circ} 26-27$, p.149-162, 2002-2003.

.Exercices écrits et cahiers d'élèves : réflexions sur des pratiques de longue durée, Le Télémaque, $n^{\circ}$ 24, p.81-110, 2003.

- Les cahiers scolaires: écrire en ordonnant les monde des savoirs. Comunicação proferida no VII Congresso Internacional Historia de la Cultura Escrita, Alcalá de Henares, 8 de julho de 2005.

CHARTIER, A.M.; RENARD, P. Cahiers et classeurs: les supports ordinaires du travail scolaire. Repères. $n^{\circ} 22$, p. 135-159, 2000.

CODO, W.; VASQUES-MENEZES, I. ; Burnout: Sofrimento Psíquico dos Trabalhadores em Educação. Cadernos de Saúde do Trabalhador - CUT. v.14, 53 p. ed. São Paulo: CUT, 2000. Disponível em: <http://www.cnte.org.br/anexos/Burnout_Cartilha_CNTE_e_ CUT.pdf>. Acesso em: 3 nov 2007.

CODO, W. (coord.) Educação: carinho e trabalho. Petrópolis: Vozes, 2006.

COLOTTA, P. La inserción de los escolares en la cultura escrita: un análisis de cuadrenos escolares en Espana y en Argentina, Projeto de Doutorado, Universidad de Alcalá de Henares, setembro, 2005. [Digitado]

COSTA, E.L.R. Referenciais Teóricos para a Análise Neuropsicológica de Cadernos Escolares (uma técnica auxiliar do diagnóstico). 1983, 155f. Dissertação (Mestrado em Psicologia Clínica) - Instituto de Psicologia, Universidade de São Paulo, São Paulo 
. AAnálise Neuropsicológica da Escrita em Cadernos Escolares. 1993, $214 \mathrm{f}$. Tese (Doutorado em Psicologia Clínica) - Instituto de Psicologia, Universidade de São Paulo, São Paulo.

DANCEL, B. Le Cahier d'Élève: approche historique. Repères, n 22, p.121-133, 2000.

DAVIDOV, V. La ensenãnza escolar y el desarrollo psiquico: investigación teórica y experimental. Moscú: Editorial Progresso, 1988.

DEFODON, C. Cahiers scolaires. In: Buisson, F. Dictionnaire de pédagogie et d'instruction primaire. Paris: Hachette, 1887.

DELEUZE, G. Qu'est-ce qu'un dispositif? In : Michel Foucault Philosophe: rencontre internationale Paris 9, 10, 11 janvier1988, Paris: Éditions du Seuil, 1989.

EZPELETA, J. Pesquisa participante. São Paulo: Cortez, 1989.

FARACO, C.A. Autor e Autoria. In: Bakhtin: conceitos-chave. São Paulo: Contexto, 2005.

FOUCAULT, M.; Dits et écrits II: 1976-1978, Paris: Galimard, 2001.

.Qu'est-ce qu’un auteur? In: Foucault, M. Dits e Écrits I: 1954-1975. Paris: Gallimard, 2001.

FARIA, V. L. B. No caderno da criança o retrato da escola. 1988. 258 f. Dissertação (Mestrado em Educação) - Faculdade de Educação, Universidade Federal de Minas Gerais, Belo Horizonte. 
GADOTTI, Moacir. Interdisciplinaridade: atitude e método. Disponível em: <http:// www.paulofreire.org/Moacir_Gadotti/Artigos/Portugues/Filosofia_da_Educacao/ Interdisci_Atitude_Metodo_1999.pdf> Acesso em: 18 de agosto 2007.

GEERTZ, C. A interpretação das culturas. Rio de Janeiro: LTC, 1989.

GIGUERE, J.; REUTER, Y. Les cahiers et classeurs et la construction de l'image da la discipline à l'école primaire. Actes du colloque Construction des connaissances et langage dans dans les disciplines d'enseignement, Bordeaux : Université Lille 3, p. 58-75,2003.

GOULD, S.J. A Falsa Medida do Homem. São Paulo: Martins Fontes, 1999.

GRUNSTEIN, R.; PECNARD, J.; DANCEL, B. Nos cahiers d'écoliers, Paris: Les ArènesFrance Info, 2002.

GVIRTZ, S. Del curriculum prescripto al curriculum enseñado. Buenos Aires: Ed. Aique, 1997.

. El discurso escolar a través de los cuadernos de clase. Buenos Aires: Eudeba Facultad de Filosofia e Letras Universidad de Buenos Aires, 1999.

HÉBRARD, J. Por uma bibliografia material das escrituras ordinárias: a escritura pessoal e seus suportes. In: MIGNOT, A.C.V.; BASTOS, M.H.C.; CUNHA, M.T.S., (org) Refúgios do Eu: educação, história, escrita autográfica. Florianópolis: Mulheres, 2000. 
.Por uma bibliografia das escritas ordinárias: o espaço gráfico do caderno escolar (França - séculos XIX e XX). Revista Brasileira de Educação, no 1, p. 115-141, 2001.

HUBERT, C.; HÉBRARD, J. Fais ton travail. Enfance \& Cultures, n², p. 46-57, 1979.

JULIA, D. A Cultura Escolar como objeto histórico. Revista Brasileira de Educação, $n^{\circ} 1$, p. 9-43, 2001.

KAGER, S. As dimensões afetivas no processo de avaliação. In: Afetividade e práticas pedagógicas. São Paulo: Casa do Psicólogo, 2006.

LEONTIEV, A. O Desenvolvimento do Psiquismo. Lisboa: Horizonte, 1978.

LÜDKE, M.; ANDRÉ, M.E.D.A. Pesquisa em educação: abordagens qualitativas. São Paulo: EPU, 1986.

MADRIZ, E. Focus groups in feminist research. In: DENZIN, N.K. \& LINCOLN, Y.S. (eds.) Handbook of qualitative research. 2nd Ed. Thousand Oaks: Sage, 2000.

MERCADO, R. La construcción de la documentación etnográfica. In: Rockwell, E. et al. La práctica docente y su contexto institucional e social. Informe Final, México, v. 3, p. 140-171, 1987. Digitado.

MIGNOT, A.C.V. Tangenciando imagens: bastidores dos suportes da escrita escolar. In: Oliveira, I. B; Alves, N e Barreto, R. G. Pesquisa em Educação: métodos, temas e linguagens. Rio de Janeiro: DP\&A, 2005. 
MOYSÉS, M.A.A. A Institucionalização Invisível: crianças que não-aprendem-naescola. Campinas: Mercado das Letras, 2001.

MORENO, M Como se ensina a ser menina: o sexismo na escola. São Paulo: Editora Moderna/UNICAMP, 1999.

NÓVOA, A. Perspectivas de renovação da história da educação em Portugal. In: NÓVOA, A.; BERRIO, J., (Ed.). A história da educação em Espanha e Portugal: investigação e actividades. Lisboa: Sociedade Portuguesa de Ciências da Educação: Sociedade Espanhola de Ciências da Educação, p. 11-22,1993.

OLIVEIRA, I.B de. A rebeldia do/no cotidiano: regras de consumo e usos transgressores das tecnologias na tessitura da emancipação social. In: Subjetividades, tecnologias e escolas. Rio de Janeiro: DP\&A, 2002.

PATTO, M. H. S. A Produção do Fracasso Escolar: histórias de submissão e rebeldia. São Paulo: T. A. Queiroz, 1990.

- Para uma Crítica da Razão Psicométrica. Psicologia USP, Vol.8, n¹. São Paulo, p. 47-62, 1997.

ROCKWELL, E. Reflexiones sobre el proceso etnográfico. México: Centro de Investigación y Estudios Avanzados del Instituto Politecnico Nacional, 1987. Digitado.

SADALLA, A.M.F.;BARIANI, I.C.D.; ROCHA, M.S.P.M. Roteiro de Observação e Análise de Material Escrito. Psicologia Escolar e Educacional, Vol. 3, nº 2, p. 171-174, 1999. 
SANTOS, A.A.C. e. Cadernos escolares na primeira série do ensino fundamental: funções e significados. 2002. 152 f. Dissertação (Mestrado em Psicologia). Instituto de Psicologia, Universidade de São Paulo, São Paulo.

SARAMAGO, S.S.S. Metodologias de pesquisa empírica com crianças. Sociologia, problemas e práticas, n. ${ }^{\circ}$ 35, p. 9-29, 2001.

SATO, L.; SOUZA, M.P.R de. Contribuindo para Desvelar a Complexidade do Cotidiano Através da Pesquisa Etnográfica em Psicologia. Psicologia USP, v. 12, no 2, p.29-47, 2001.

SAVIANI, D. Pedagogia histórico-crítica: primeiras aproximações. Campinas: Autores Associados, 1996.

SIMIONATO, M. Apreendido caderno de aluno de Nova Odessa. Folha de São Paulo, São Paulo, 20 novembro 2004, Cotidiano, C4, Disponível em: <http://fws.uol.com. br/folio.pgi/fsp2004.nfo/query=nova+odessa+professora/doc/\{@ 1\}/hit_headings/words=4/hits_only?> Acesso em 19 maio 2006.

SMOLKA, A.L.B.; GÓES, M. C.R. de; PINO, A. A constituição do sujeito: uma questão recorrente? In: WERTSCH, J. V.; DEL RÍO, P.; ALVAREZ, A. Estudos socioculturais da mente, Porto Alegre: Artmed, 1998.

SOUZA, M.P.R. A queixa escolar e o predomínio de uma visão de mundo. In MARCONDES, A.M.; SOUZA, M.P.R (Orgs). Psicologia Escolar: em busca de novos rumos. São Paulo: Casa do Psicólogo, 2004. 
- As contribuições dos estudos etnográficos na compreensão do fracasso escolar no Brasil. In: MARCONDES, A.M.; SOUZA, M.P.R (Orgs). Psicologia Escolar: em busca de novos rumos. São Paulo: Casa do Psicólogo, 2004.

SOUZA, M. P. R. ; LIMA, M.A. ; BRAGA, T.B.M. . Violência domestica e fracasso escolar: uma interface das relações escola-família. In: 9o SIICUSP Simpósio Internacional de Iniciação Científica da USP, 2001, São Paulo. Anais do 9o SIICUSP, 2001.

TANAMACHI, E.R. Mediações teórico-práticas de uma visão crítica em Psicologia Escolar. In: Tanamachi, E.R., Proença, M., Rocha, M. (Orgs.), Psicologia e Educação: Desafios teórico-práticos. São Paulo: Casa do Psicólogo, p. 73-104, 2002.

TEMPLE, G. C. Alunos copistas: uma análise do processo de escrita a partir da perspectiva histórico-cultural. 2007. 147f. Dissertação (Mestrado em Psicologia). Instituto de Psicologia, Universidade de São Paulo, São Paulo.

VIÑAO, A. Los Cuadernos Escolares como Fuente Histórica: aspectos metodológicos e historiográficos, Universidad de Murcia (Espanha) 2006. 19p. [Digitado]

VYGOTSKY, L. S. A formação social da mente. São Paulo: Martins Fontes, 1989. 